\title{
Inativação de Indicadores Patogênicos em Sistemas Combinados de Tratamento e Pré-Desinfecção de Esgoto Sanitário
}

\author{
Patrícia Bilotta Monaco
}

Tese apresentada à Escola de Engenharia de São Carlos da Universidade de São Paulo, como parte dos requisitos para obtenção do título de Doutor em Engenharia Civil na Área de Hidráulica e Saneamento

ORIENTADOR: Prof. Dr. Luiz Antonio Daniel 
Dedico esta conquista aos meus pais, Maria Célia e Dagoberto, meus irmãos Marcel e Kelly Cristina e ao sobrinho Renato como reconhecimento ao apoio e carinho que me dedicaram, sem os quais não seria possível a concretização deste sonho.

Este trabalho dedico ainda aos meus amigos de todos os dias que muito me incentivaram, verdadeiros companheiros nas alegrias e nos desafios que fizeram parte da minha história.

E especialmente, com todo meu amor e entendimento, dedico esta obra à Deus e aos seus mensageiros, sempre presentes em todos os momentos da minha vida. 
À minha grande amiga Patrícia Campos, por sua inigualável amizade, aos bons momentos que compartilhamos na vida e àqueles que virão.

Ao Professor Luiz Antonio Daniel por sua sábia orientação que me permitiu desenvolver este trabalho.

Aos colegas e funcionários do Departamento de Hidráulica e Saneamento pela colaboração e amizade, em especial aos técnicos de laboratório Roberto Cezar Bérgamo e Glauce Guimarães Pereira, cuja solicitude muitas vezes superou suas atribuições profissionais.

À Coordenadoria de Aperfeiçoamento de Pessoal de Nível Superior pela concessão da bolsa de estudos e à Fundação de Amparo à Pesquisa do Estado de São Paulo pelo auxílio pesquisa oferecido.

Aos profissionais e voluntários em todo mundo que têm se dedicado ao desenvolvimento de software livre, cujos resultados foram de grande valia na realização deste trabalho, em especial aos que suportam o projeto GNU, o sistema operacional Linux e o processador de textos LTEX - e ao Prof. Dr. Francisco J. Monaco por me ensinar a utilizá-lo. 


\section{Resumo}

\section{BILOTTA, P. (2006). INATIVAÇÃO DE INDICADORES PATOGÊNI- COS EM SISTEMAS COMBINADOS DE TRATAMENTO E PRÉ- DESINFECÇÃO DE ESGOTO SANITÁRIO. São Carlos, 2006. Tese (Doutorado) - Escola de Engenharia de São Carlos, Universidade de São Paulo.}

A proposta apresentada se baseia na introdução de um estágio intermediário de desinfecção previamento ao tratamento biológico visando intensificar os efeitos do estágio seguinte destinado à desinfecção convencional. Para estudo de caso foram aplicadas as técnicas de ozonização e radiação UV combinadas em instalações piloto que simulam duas condições seqüenciais de desinfecção. O desempenho do método proposto foi avaliado através de exames microbiológicos de amostras do efluente anaeróbio previa e posteriormente à desinfecção, utilizando indicadores de contaminação por bactérias (E. coli e coliformes totais), vírus (colifagos) e protozoários (Clostridium perfringens).

Os resultados obtidos no sistema combinado pré-desinfecção/desinfecção revelaram eficiência de inativação superior quando comparada ao procedimento convencional. Nas análises de E.coli, por exemplo, a aplicação de apenas $1 \mathrm{mg}$ de $\mathrm{O}_{3} / \mathrm{L}$ ou $51 \mathrm{~mW}$ de radiação $/ \mathrm{cm}^{2}$, na primeira etapa de desinfeção, foi suficiente para se alcançar $1 \log$ acima do valor correspondente ao método convencional. Mesmo indicadores mais resistentes como C. perfringens apresentaram redução da fração $\mathrm{N} / \mathrm{N}_{0}$ da ordem de 1 log em relação ao método proposto.

Além disso, estes níveis de inativação foram alcançados mesmo sob a influência de elevada concentração de SST, SSV e DQO na entrada na unidade piloto destinada à pré-desinfecção. Entre as seqüências de experimentação investigadas $\left(\mathrm{O}_{3} / \mathrm{O}_{3}, \mathrm{O}_{3} / \mathrm{UV}, \mathrm{UV} / \mathrm{O}_{3}\right.$ e UV/UV) não foram observadas grandes variações. De modo semelhante, os resultados revelaram que a relação $\mathrm{N} / \mathrm{N}_{0}$, para os indivíduos submetidos ao sistema combinado, não foi afetada pelo aumento no tempo de exposição ao agente inativante $\left(\mathrm{O}_{3}: 5,7,10 \mathrm{~min}\right.$; UV: 30, 60, 120s).

Considerando as baixas dosagens de $\mathrm{O}_{3}$ e UV aplicadas na primeira etapa, somada às condições limitadas de desempenho do sistema real examinado, os níveis de inativação alcançados sugerem grande potencialidade de utilização do método alternativo proposto, comprovando sua viabilidade técnica.

Palavras-chave: Radiação ultravioleta, ozônio, desinfecção de esgoto sanitário, indicadores de contaminação por patogênicos, Escherichia coli, Clostridium perfringens, colifagos e coliformes totais. 


\title{
Abstract
}

\author{
BILOTTA, P. (2006). INACTIVATION OF PATHOGENS TRACERS \\ IN COMBINED SYSTEMS FOR SANITARY SEWER TREATMENT \\ AND PRE-DISINFECTION. São Carlos, 2006. Thesis (Doctorate) - Escola \\ de Engenharia de São Carlos, Universidade de São Paulo.
}

The present proposition is based on the introduction of an intermediate disinfection stage before the biological treatment, in order to intensify the effects of the next stage employed in conventional disinfection. Studies were performed using combined ozonization and UV radiation techniques, in a model installation that simulates two sequential disinfection conditions. The performance of the method was evaluated using microbiological exams of samples taken from the anaerobic effluent before and after the disinfection. Bacterial (E. coli and total coliforms), viral (coliphages) and protozoan (Clostridium perfringens) contamination tracers were used in such exams.

Results obtained by combining pre-disinfection and disinfection reveal superior inactivation efficiency as compared to the conventional procedure. For example, in the E. coli analysis the application of only $1 \mathrm{mg}$ of $\mathrm{O}_{3} / \mathrm{L}$ or $51 \mathrm{~mW} / \mathrm{cm}^{2}$ of radiation in the first disinfection stage was enough for achieving 1 log above the convention method. Even more resistant tracers, such as $C$. perfringens, showed aproximatelly $1 \log$ of reduction in the $N / N_{0}$ fraction in the proposed method. Besides, these inactivation levels were achieved even for high concentrations of SST, $S S V$ and $D Q O$ in the entrance of the pre-disinfection unit. No significant variations were observed among the disinfection sequences $\left(\mathrm{O}_{3} / \mathrm{O}_{3}, \mathrm{O}_{3} / \mathrm{UV}, \mathrm{UV} / \mathrm{O}_{3}\right.$, and $U V / U V)$. Similarly, the results showed that the $N / N_{0}$ relation, for individuals submitted to the combined system, was not affected by the increase of the exposition time to the inactivation agent ( $\left.\mathrm{O}_{3}: 5,7,10 \mathrm{~min} ; \mathrm{UV}: 30,60,120 \mathrm{~s}\right)$.

Taking into account the low dosages of $\mathrm{O}_{3}$ and $U V$ applied in the first stage and the limited performance conditions of the real system, the achieved inactivation levels suggest a great potential for the alternative method proposed, demonstrating its technical viability.

Key-words: Ultra violet radiation, ozone, sanitary sewer disinfection, pathogens contamination tracers, E. coli, Clostridium perfringens, coliphages, total coliforms. 


\section{Lista de Figuras}

FIGURA 3.1 Estruturas de ressonância do ozônio molecular. . . . . . 7

FIGURA 3.2 Efeito dos parâmetros pH e temperatura na solubilidade do gás ozônio. . . . . . . . . . . . . . . . . . . . . 11

FIGURA 3.3 Efeito da vazão do gás de alimentação na solubilidade do ozônio. . . . . . . . . . . . . . . . . . . 12

FIGURA 3.4 Mecanismo de decomposição indireto do ozônio molecular. 17

FIGURA 3.5 Efeito das variáveis tempo de contato e concentração de $\mathrm{O}_{3}$ na fração de Giardia lamblia sobrevivente. . . . . . . . . . . . 19

FIGURA $3.6 \quad$ Espectro eletromagnético. . . . . . . . . . . . . . . 20

FIGURA 3.7 Representação simplificada de câmaras de contato projetadas para utilização de radiação UV. . . . . . . . . . . . . . . . 24

FIGURA 3.8 Efeito da concentração de sólidos na inativação de bactérias heterótrofas com radiação UV. . . . . . . . . . . . . . . . . . . 32

FIGURA 3.9 Desempenho dos métodos de oxidação $\mathrm{O}_{3} / \mathrm{UV}, \mathrm{O}_{3}$ e UV. 35

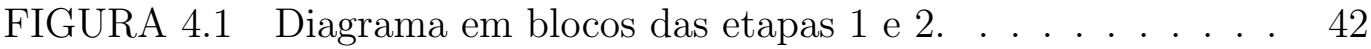

FIGURA 4.2 Representação das operações unitárias da fase experimental. . . . . . . . . . . . . . . . . . . 43

FIGURA 4.3 Representação das operações unitárias e organograma experimental. .................... 44 
FIGURA 4.4 Etapas operacionais relativas a primeira fase experimental. 45

FIGURA 4.5 Esquema simplificado da instalação piloto para a etapa 1. 47

FIGURA 4.6 Representação esquemática do reator fotoquímico da etapa

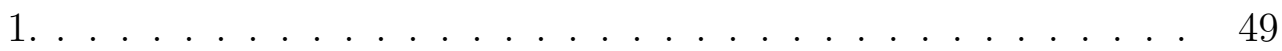

FIGURA 4.7 Unidade experimental para o tratamento biológico. . . . 50

FIGURA 4.8 Representação simplificada da unidade piloto $\mathrm{O}_{3}$ da etapa

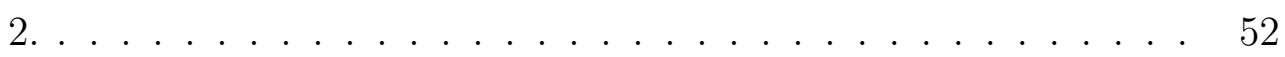

FIGURA 4.9 Câmara de ozonização para a etapa $2 . \ldots . .53$

FIGURA 4.10 Unidade experimenal para os ensaios com radiação UV na etapa $2 . \ldots \ldots \ldots \ldots \ldots \ldots$

FIGURA 4.11 Representação simplificada da câmara de irradiação para a etapa $2 \ldots \ldots \ldots \ldots \ldots \ldots \ldots$

FIGURA 4.12 Leitura da intensidade de radiação pontual em 254nm. . 60

FIGURA 5.1 Variação da DQO nas etapas 1 e 2 (ensaio 2) . . . . . . 75

FIGURA 5.2 Variação da concentração de SST nas etapas 1 e 2 (ensaio

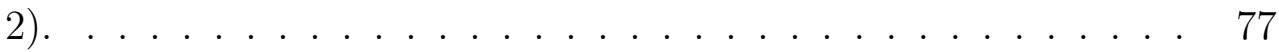

FIGURA 5.3 Variação da concentração de SSV nas etapas 1 e 2 (ensaio 2). . . . . . . . . . . . . . . . . . . . 78

FIGURA 5.4 Variação da população de E. coli na etapa 2 (ensaio 2). 86

FIGURA 5.5 Variação da população de colifagos na etapa 2 (ensaio 2). 87

FIGURA 5.6 Variação da população de C. perfringens na etapa 2 (ensaio 2$) \ldots \ldots \ldots \ldots$

FIGURA 5.7 Variação da população de coliformes totais na etapa 2 (ensaio 2) . . . . . . . . . . . . . . . . . . . . 89

FIGURA 8.1 Variação da DQO nas etapas 1 e 2 (ensaio 1). . . . . . . 112 
FIGURA 8.2 Variação da DQO nas etapas 1 e 2 (ensaio 3). . . . . . . 113

FIGURA 8.3 Variação da concentração de SST nas etapas 1 e 2 (ensaio 1). . . . . . . . . . . . . . . . . 114

FIGURA 8.4 Variação da concentração de SST nas etapas 1 e 2 (ensaio $3)$

FIGURA 8.5 Variação da concentração de SSV nas etapas 1 e 2 (ensaio 1). . . . . . . . . . . . . . . . . 116

FIGURA 8.6 Variação da concentração de SSV nas etapas 1 e 2 (ensaio 3). . . . . . . . . . . . . . . . . . 117

FIGURA 8.7 Variação da população de E. coli na etapa 2 (ensaio 1). 122

FIGURA 8.8 Variação da população de colifagos na etapa 2 (ensaio 1). 123

FIGURA 8.9 Variação da população de C. perfringens na etapa 2 (ensaio 1 ). . . . . . . . . . . . . . . . . . . . 124

FIGURA 8.10 Variação da população de coliformes totais na etapa 2 (ensaio 1) . . . . . . . . . . . . . . . . . . . . 125

FIGURA 8.11 Variação da população de E. coli na etapa 2 (ensaio 3). 126

FIGURA 8.12 Variação da população de colifagos na etapa 2 (ensaio 3). 127

FIGURA 8.13 Variação da população de C. perfringens na etapa 2 (ensaio 3$) \ldots \ldots \ldots \ldots \ldots \ldots$

FIGURA 8.14 Variação da população de coliformes totais na etapa 2 (ensaio 3) . . . . . . . . . . . . . . . . . . . . . . . 129 


\section{Lista de Tabelas}

TABELA 3.1 Organismos patogênicos comumente encontrados em esgoto sanitário. . . . . . . . . . . . . . . . . 6

TABELA 3.2 Potencial de Oxidação. . . . . . . . . . . . . . . 7

TABELA 3.3 Métodos para determinação da concentração de $O_{3}$. . . 13

TABELA 3.4 Espécies iniciadoras, promotoras e inibidoras de reações em cadeia. . . . . . . . . . . . . . . . . . 15

TABELA 3.5 Energia de ligação para importantes grupos funcionais. 21

TABELA 3.6 Métodos para determinação da intensidade média da lâmpada. . . . . . . . . . . . . . . . 27

TABELA 3.7 Dose de radiação UV relativa a inativação de 90\%. . . . 31

TABELA 3.8 Influência da fotorreativação na inativação de bactérias E. coli e Streptococcus faecalis. . . . . . . . . . . . . . . 33

TABELA 3.9 Efeito das técnicas convencional e combinada na remoção de microrganismos. . . . . . . . . . . . . . . . 37

TABELA 4.1 Descrição sucinta da fase experimental. . . . . . . . . . 41

TABELA 4.2 Dados operacionais para a etapa $1 \ldots \ldots$. . . . . . . 51

TABELA 4.3 Dados operacionais para a segunda etapa da pesquisa. . 56

TABELA 4.4 Métodos analíticos para caracterização das várias amos-

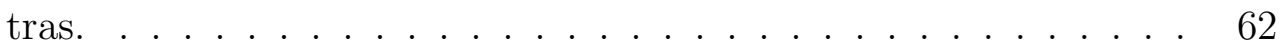


TABELA 5.1 Organograma de abordagem dos resultados experimentais. 63

TABELA 5.2 Capacidade de irradiação da lâmpada germicida com o tempo de operação. . . . . . . . . . . . . . . . 66

TABELA 5.3 Produção de ozônio correspondente a diferentes vazões de oxigênio na entrada do equipamento. . . . . . . . . . . 68

TABELA 5.4 Valores de vazão e dose efetiva relativos aos ensaios 1, 2 e $3\left(\mathrm{O}_{3}\right) \ldots \ldots \ldots \ldots \ldots \ldots$

TABELA 5.5 Intensidade pontual de radiação UV no reator fotoquímico. 71

TABELA 5.6 Valores de absorbância, intensidade média e dose efetiva relativos aos ensaios 1,2 e $3(\mathrm{UV}) \ldots \ldots \ldots \ldots 72$

TABELA 5.7 Variação da população de Escherichia coli (ensaio 2). 81

TABELA 5.8 Variação da população de colifagos (ensaio 2). . . . . . 82

TABELA 5.9 Variação da população de Clostridium perfringens (ensaio 2) . . . . . . . . . . . . . . . . . . . . 83

TABELA 5.10 Variação da população de coliformes totais (ensaio 2). . 84

TABELA 5.11 Eficiência de inativação de Escherichia coli (ensaio 2). . 91

TABELA 5.12 Eficiência de inativação de colifagos (ensaio 2). . . . . . 91

TABELA 5.13 Eficiência de inativação de Clostridium perfringens (ensaio 2) . . . . . . . . . . . . . . . . . . . . . . . . 92

TABELA 5.14 Eficiência de inativação de coliformes totais (ensaio 2). . 92

TABELA 8.1 Caracterização das amostras coletadas no ensaio 1 para a seqüência $O_{3} / O_{3} \ldots \ldots \ldots \ldots 1$. . . . . . . . . . . 101

TABELA 8.2 Caracterização das amostras coletadas no ensaio 1 para a seqüência $O_{3} / U V \ldots \ldots \ldots$

TABELA 8.3 Caracterização das amostras coletadas no ensaio 1 para a seqüência $U V / O_{3} \ldots \ldots \ldots$. . . . . . . . . . . . . . 103 
TABELA 8.4 Caracterização das amostras coletadas no ensaio 1 para a seqüência $U V / U V \ldots \ldots$. . . . . . . . . . . . . . . . . . . . 104

TABELA 8.5 Caracterização das amostras coletadas no ensaio 2 para a seqüência $O_{3} / O_{3} \ldots \ldots \ldots$. . . . . . . . . . . . . . 105

TABELA 8.6 Caracterização das amostras coletadas no ensaio 2 para a seqüência $O_{3} / U V \ldots \ldots \ldots$. . . . . . . . . . . . 106

TABELA 8.7 Caracterização das amostras coletadas no ensaio 2 para a seqüência $U V / O_{3} \ldots \ldots \ldots$

TABELA 8.8 Caracterização das amostras coletadas no ensaio 2 para

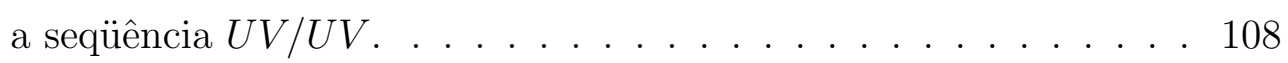

TABELA 8.9 Caracterização das amostras coletadas no ensaio 3 para a seqüência $O_{3} / O_{3} \ldots \ldots \ldots$. . . . . . . . . . . . 109

TABELA 8.10 Caracterização das amostras coletadas no ensaio 3 para a seqüência $O_{3} / U V \ldots \ldots \ldots$

TABELA 8.11 Caracterização das amostras coletadas no ensaio 3 para a seqüência $U V / O_{3} \ldots \ldots \ldots$

TABELA 8.12 Variação da população de Escherichia coli (ensaios 1 e 3).118

TABELA 8.13 Variação da população de colifagos (ensaios 1 e 3). . . . 119

TABELA 8.14 Variação da população de Clostridium perfringens (ensaios 1 e 3) . . . . . . . . . . . . . . . . . 120

TABELA 8.15 Variação da população de coliformes totais (ensaios 1 e 3).121

TABELA 8.16 Eficiência de inativação de Escherichia coli (ensaios 1 e 3). . . . . . . . . . . . . . . . . 130

TABELA 8.17 Eficiência de inativação de colifagos (ensaios 1 e 3). . . 131

TABELA 8.18 Eficiência de inativação de Clostridium perfringens (ensaios 1 e 3 ). . . . . . . . . . . . . . . . . . . . 132 
TABELA 8.19 Eficiência de inativação de coliformes totais (ensaios 1 e 3). . . . . . . . . . . . . . . . . . 133 


\section{Sumário}

Resumo i

$\begin{array}{lll}\text { Abstract } & \text { ii }\end{array}$

Lista de Figuras iii

Lista de Tabelas vi

1 Introdução 1

2 Objetivo 3

3 Revisão Bibliográfica $\quad 4$

3.1 Aspectos Gerais . . . . . . . . . . . . . . 4

3.2 Resistência ao Agente de Inativação . . . . . . . . . . . . . 5

3.3 Ozonização . . . . . . . . . . . . . . . . . 6

3.3 .1 Propriedades . . . . . . . . . . . . . . . 7

3.3.2 Gerador de Ozônio . . . . . . . . . . . . . . . . . . . 9

3.3.3 Câmara de Ozonização . . . . . . . . . . . . . . . . 10

3.3.4 Transferência de Massa Gás-Líquido . . . . . . . . . . . . 10

3.3.5 Análise das Fases Líquida e Gasosa . . . . . . . . . . . . . 13

3.3.6 Mecanismo de Decomposição . . . . . . . . . . . . . . . . 14

3.3.7 Mecanismo de Inativação . . . . . . . . . . . . . . . . 17

3.3 .8 Dose de Ozônio . . . . . . . . . . . . . . . . . . . . . . 18

3.4 Radiação Ultravioleta . . . . . . . . . . . . . . . . . . . . . . 19

3.4 Propriedades . . . . . . . . . . . . . . 20

3.4 .2 Fonte de Radiação UV . . . . . . . . . . . . . . . . . . . 22

3.4.3 Câmara de Contato . . . . . . . . . . . . . . 23 
3.4.4 Transmissão da Radiação . . . . . . . . . . . . . . 25

3.4.5 Determinação da Intensidade de Energia Radiante . . . . 26

3.4 .6 Mecanismo de Inativação . . . . . . . . . . . . . . . . . . 29

3.4 .7 Dose de Radiação . . . . . . . . . . . . . . . . 30

3.4 .8 Fotorreativação . . . . . . . . . . . . . . . 32

3.5 Sistemas Combinados . . . . . . . . . . . . . . . . . 33

3.5.1 Efeito Oxidativo . . . . . . . . . . . . . 34

3.5.2 Efeito Germicida . . . . . . . . . . . . . . 36

$\begin{array}{llr}4 & \text { Metodologia } & 40\end{array}$

4.1 Fase Experimental: Planejamento . . . . . . . . . . . . . . . 40

4.2 Descrição da Etapa 1 . . . . . . . . . . . . . . . . . . . . . . . . . 43

4.2 .1 Ozonização . . . . . . . . . . . . . . . . . . . 46

4.2 .2 Radiação UV . . . . . . . . . . . . . . . . . . . . . . . 48

4.2 .3 Unidade de Tratamento Biológico . . . . . . . . . . . . . . 49

4.2.4 Parâmetros Experimentais: Etapa 1 . . . . . . . . 50

4.3 Descrição da Etapa $2 \ldots \ldots$. . . . . . . . . . . . . . . 51

4.3 .1 Ozonização . . . . . . . . . . . . . . . . 51

4.3 .2 Ensaios com Radiação UV . . . . . . . . . . . . . 54

4.3.3 Parâmetros Experimentais: Etapa 2 . . . . . . . . 56

4.4 Procedimentos Auxiliares . . . . . . . . . . . . . . . . 56

4.4.1 Calibração do Equipamento Gerador de $\mathrm{O}_{3}$. . . . . . . 57

4.4 .2 Intensidade Média de Radiação UV . . . . . . . . . . . . 59

4.5 Modelo de Inativação . . . . . . . . . . . . . . . . . . . . . . 61

4.6 Análises e Exames . . . . . . . . . . . . . . . . . . . . . . . . . 61

5 Resultados e Discussões $\quad 63$

5.1 Parte I: Pré-Desinfecção ． . . . . . . . . . . . . . . . . . . . . . . 64

5.1 .1 Ozonização . . . . . . . . . . . . . . . . . . 64

5.1 .2 Radiação UV . . . . . . . . . . . . . . . . . . . 66

5.2 Parte II: Desinfecção . . . . . . . . . . . . . . . . . . . 67

5.2.1 Ensaios com Ozônio . . . . . . . . . . . . . . . 67

5.2.2 Ensaios com Radiação UV . . . . . . . . . . . . 71

5.3 Parte III: Unidades Combinadas . . . . . . . . . . . . . . . . 73 
5.3.1 Caracterização das Amostras . . . . . . . . . . . . . 73

5.3 .2 Análises Físico-Químicas . . . . . . . . . . . 73

5.3.3 Exames Microbiológicos . . . . . . . . . . . . 79

5.4 Parte IV: Estudo Comparativo . . . . . . . . . . . . . . . . . . 93

$\begin{array}{llr}6 & \text { Conclusões } & 96\end{array}$

$\begin{array}{lll}7 & \text { Considerações Finais } & 98\end{array}$

$\begin{array}{llr}8 & \text { Anexo A } & 100\end{array}$

$\begin{array}{lr}\text { Referências Bibliográficas } & 134\end{array}$ 


\section{Capítulo 1}

\section{Introdução}

Segundo a Organização Mundial da Saúde (OMS), grande parte das doenças contraídas pelo homem são adquiridas no contato direto ou indireto com águas contaminadas lançadas indiscriminadamente em sistemas abertos como rios e lagos, particularmente o esgoto sanitário bruto.

A atenção voltada à saúde pública associada às questões de natureza ambiental e à necessidade de viabilizar estratégias de desenvolvimento sustentável tem incentivado pesquisas em busca de tecnologias adequadas e viáveis no controle da qualidade de efluentes.

Neste contexto a desinfecção é certamente uma das etapas mais importantes. Nela é promovida a inativação de diferentes espécies de microrganismos, muitas vezes responsáveis por inúmeras doenças, para se atingir níveis de emissão aceitos pela legislação vigente e viabilizar, em termos biológicos, seu reaproveitamento.

Não obstante o reconhecido progresso científico e tecnológico observado neste âmbito, a questão do pós-tratamento converge ainda para a necessidade de um entendimento mais amplo das possibilidades existentes e de outras a serem alcançadas.

Como exemplo, o emprego do cloro em unidades de desinfecção tem sido bastante questionado em virtude de seu potencial mutagênico e cancerígeno, aliado ao efeito nocivo do contato de comunidades aquáticas com águas cloradas. Portanto, 
em substituição à cloração no controle de organismos patogênicos, surgiram nas últimas décadas tecnologias alternativas promissoras, dentre as quais se destaca o uso da ozonização e da radiação ultravioleta.

As principais vantagens associadas a ambos os métodos, em comparação aos reagentes clorados, é a superior capacidade de destruir espécies como vírus e bactérias, em um curto intervalo de tempo, a não geração de compostos como $\mathrm{THM}^{1}$, aumento da concentração de oxigênio dissolvido no efluente ozonizado ${ }^{2}$ e, por fim, a atividade germicida praticamente independe do $\mathrm{pH}$.

A escolha dos agentes de inativação se deve à continuidade do programa experimental, em escala laboratorial, iniciado pelo autor no período do mestrado, cujos resultados revelaram a grande potencialidade de aplicação do ozônio e da radiação UV em sistemas de desinfecção convencionais [BILOTTA (2000)].

Como resultado desses estudos nasceu o interesse na investigação dos efeitos microbiológicos quando da utilização de duas etapas de desinfecção para inativar indicadores de contaminação por bactérias, vírus e protozoários em alternativa ao método convencional com uma única etapa.

A eficiência do sistema proposto é avaliada em quatro diferentes seqüências na primeira e segunda etapa $\left(\mathrm{O}_{3} / \mathrm{O}_{3}, \mathrm{O}_{3} / \mathrm{UV}, \mathrm{UV} / \mathrm{O}_{3}\right.$ e $\left.\mathrm{UV} / \mathrm{UV}\right)$, e três condições de tempo de contato para uma mesma dosagem na segunda etapa.

\footnotetext{
${ }^{1}$ Com exceção das reações de oxidação entre o ozônio e possíveis compostos halogenados presentes no esgoto sanitário que podem levar a formação de THM's.

${ }^{2}$ Resultado de reações intermediárias com a matéria orgânica.
} 


\section{Capítulo 2}

\section{Objetivo}

Neste projeto de pesquisa a autora buscou investigar o efeito da aplicação de duas etapas de desinfecção na inativação dos indicadores Escherichia coli, Clostridium perfringens, colifagos e coliformes totais presentes no esgoto sanitário efluente de tratamento anaeróbio em reator UASB.

$\mathrm{Na}$ instalação experimental foram simulados os procedimentos convencional e alternativo de desinfecção, isto é, um e dois estágios, frente à adição de ozônio gasoso e radiação ultravioleta em diferentes seqüências $\left(\mathrm{O}_{3} / \mathrm{O}_{3}, \mathrm{O}_{3} / \mathrm{UV}, \mathrm{UV} / \mathrm{O}_{3}\right.$ e UV/UV), concentrações e tempo de exposição.

Pertenceu ainda ao escopo dos objetivos deste trabalho determinar a influência da presença de matéria orgânica, em termos do parâmetro DQO, e da concentração de sólidos suspensos totais e voláteis na eficiência de inativação dos agentes ozônio e radiação UV. 


\section{Capítulo 3}

\section{Revisão Bibliográfica}

Nas últimas décadas, os efeitos decorrentes do lançamento indiscriminado de efluentes domésticos e industriais em sistemas naturais como rios e lagos têm despertado crescente preocupação mundial.

Como resultado dessas ações, vários países já sofrem as conseqüências da elevada contaminação de seus mananciais, principalmente nos aspectos relacionados à sensível redução das fontes de água potável disponíveis e o alto consumo de recursos para implantação de modernas unidades de tratamento de água de abastecimento que atendam à legislação sanitária.

Além de restringir ou mesmo impossibilitar seu reuso, soma-se a esta questão o risco da transmissão de doenças graves disseminadas no contato com sistemas contaminados, particularmente os que recebem esgoto sanitário. Neste contexto, se torna evidente, portanto, a necessidade da utilização de técnicas voltadas à redução do número de indicadores patogênicos para níveis aceitáveis previamente ao seu descarte.

\subsection{Aspectos Gerais}

Em unidades de tratamento de esgoto destinadas à desinfecção podem ser empregados basicamente dois princípios distintos: 1) adição de agentes químicos 
— processo químico; 2) aplicação de radiação — processo físico.

Para o primeiro caso, a capacidade de oxidação de certos compostos é a principal responsável pela destruição de estruturas bioquímicas presentes na organização celular microbiana. Estes compostos podem ser permanganato de potássio, ozônio, peróxido de hidrogênio, ácido peracético, além dos próprios halogênios como cloro, bromo e iodo.

No processo físico, por sua vez, o efeito germicida se deve ao aumento da energia celular decorrente da absorção de radiação, por grupos funcionais específicos, para a intensidade emitida na faixa dos raios UV, particularmente em $254 \mathrm{~nm}$, ao qual correspondem os menores índices de sobrevivência [WEF (1996)].

Embora a comprovada baixa resistência dos principais organismos patogênicos à cloração, o reduzido custo de operação e a facilidade de aplicação, seu uso tem sido questionado devido a formação de subprodutos altamente contaminantes no processo, a exemplo dos trihalometanos, cujo potencial mutagênico e cancerígeno já é bastante divulgado [WEF (1996)] [MILTNER et al. (1992)].

Dentre as técnicas atualmente disponíveis, particular atenção tem sido voltada ao uso do gás ozônio e da radiação ultravioleta como alternativas eficazes na desinfecção de efluentes domésticos [FAIR et al. (1971)].

\subsection{Resistência ao Agente de Inativação}

Grande variedade de microrganismos, muitos deles patogênicos ao homem, é comumente encontrada em esgoto sanitário, dentre eles particularmente bactérias, vírus, protozoários e vermes, conforme indica a Tabela 3.1.

Conseqüentemente, a diversidade de espécies presentes no efluente implica em características bioquímicas diferentes entre si resultando em divergência de comportamento quando elementos externos são introduzidos. É o caso, por exemplo, da variação de temperatura e pH ou ainda a aplicação de agentes de inativação distintos como gás ozônio, radiação UV e ácido peracético [WEF (1996)]. 
Tabela 3.1: Organismos patogênicos comumente encontrados em esgoto sanitário.

\begin{tabular}{cccc}
\hline Bactérias & Vírus & Protozoários & $\frac{\text { Vermes }}{2}$ \\
\cline { 2 - 3 } Vibrio cholerae & Poliovirus & Entamoeba histolytica & A. lumbricoides \\
Salmonella typhi & Coxsackie & Giardia lamblia & S. mansoni \\
Salmonella paratyphi & Echovirus & Balantidium coli & Taenia solium \\
Shigella spp & Adenovirus & Ancilostonia duodenale & \\
Brucela spp & Hepatite A & & \\
\hline
\end{tabular}

Fonte: WEF (1996)

Tais considerações são de grande importância no estudo e planejamento de unidades de desinfecção destinadas à etapa de desinfecção para o esgoto sanitário ou água de abastecimento. Nestes casos a resistência microbiana à adição de agente químico ou físico de inativação segue, em geral, a ordem [BITTON (1994)]:

$$
\text { Bactérias < Vírus < Protozoários }
$$

Assim, experimentos com populações mais suscetíveis aos efeitos da desinfecção requerem reduzido intervalo de tempo para atingir a taxa de remoção desejada enquanto as mais resistentes, mantidas as mesmas condições, exigem maior tempo de contato para alcançar os mesmos índices de inativação. Logo, é conveniente a utilização de exames bacteriológicos abrangentes para monitorar o comportamento de bactérias, vírus e protozoários ao longo dos ensaios.

Usualmente são empregadas bactérias Escherichia coli e Clostridium perfringens na determinação de bactérias e protozoários, respectivamente, enquanto os colifagos são indicadores da presença de vírus.

\subsection{Ozonização}

As primeiras unidades de ozonização que se têm notícia foram criadas e implantandas na França por volta da segunda metade do século 20.

No início as instalações eram projetadas apenas para tratamento de água de 
abastecimento, somente mais tarde, em meados dos anos 70, a técnica passou a ser adotada também na desinfecção de esgoto sanitário [GLAZE (1987)].

\subsubsection{Propriedades}

A molécula de ozônio possui geometria triangular onde cada vértice é ocupado por um átomo de oxigênio, formando ângulo de ligação correspondente a $116^{\circ} 49^{\prime}$. A estrutura exibe 4 modos de ressonância, representados na Figura 3.1.

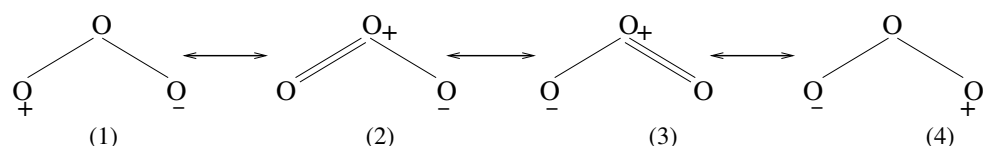

Figura 3.1: Estruturas de ressonância do ozônio molecular. Fonte: EVANS (1972)

O comportamento altamente reativo da molécula de ozônio, quando comparado a outros compostos, é atribuído a dois aspectos principais: a deficiência eletrônica das estruturas de ressonância (1) e (4) com apenas 6 elétrons em torno do átomo de oxigênio e a tendência eletronegativa do elemento oxigênio. Na Tabela 3.2 são apresentados alguns importantes agentes químicos e seus correspondentes potenciais de oxidação [FAIR et al. (1971)] [HARRIS (1995)].

Tabela 3.2: Potencial de Oxidação.

\begin{tabular}{|c|c|c|c|}
\hline \multicolumn{3}{|c|}{ Reações de Oxi-redução } & $E^{0}(V)$ \\
\hline $\mathrm{O}_{3(g)}+2 \mathrm{H}^{+}+2 \mathrm{e}$ & $\rightleftarrows$ & $\mathrm{O}_{2(g)}+\mathrm{H}_{2} \mathrm{O}$ & +2.07 \\
\hline $\mathrm{H}_{2} \mathrm{O}_{2}+2 \mathrm{H}^{+}+2 \mathrm{e}$ & $\rightleftarrows$ & $2 \mathrm{H}_{2} \mathrm{O}$ & +1.76 \\
\hline $\mathrm{MnO}_{4}^{-}+4 \mathrm{H}^{+}+3 \mathrm{e}$ & $\rightleftarrows$ & $\mathrm{MnO}_{2(s)}+2 \mathrm{H}_{2} \mathrm{O}$ & +1.69 \\
\hline $\mathrm{HOCl}+\mathrm{H}^{+}+2 \mathrm{e}$ & $\rightleftarrows$ & $\mathrm{Cl}^{-}+\mathrm{H}_{2} \mathrm{O}$ & +1.49 \\
\hline $\mathrm{Cl}_{2(g)}+2 \mathrm{e}$ & $\rightleftarrows$ & $2 \mathrm{Cl}^{-}$ & +1.36 \\
\hline $\mathrm{OCl}^{-}+\mathrm{H}_{2} \mathrm{O}+2 \mathrm{e}$ & $\rightleftarrows$ & $\mathrm{Cl}^{-}+2 \mathrm{OH}^{-}$ & +0.88 \\
\hline
\end{tabular}

A natureza fortemente oxidante do ozônio lhe confere habilidade para reagir prontamente com uma grande variedade de grupos funcionais orgânicos e organo- 
metálicos, promovendo quebra de duplas ligações carbono-carbono e originando subprodutos de menor peso molecular, muitas vezes mais biodegradáveis que seus precursores.

Como resultado, o ozônio é capaz de remover substâncias responsáveis pela cor, gosto e odor no tratamento de águas de abastecimento, e microrganismos diversos no tratamento de esgoto, incluindo espécies resistentes a outras técnicas de desinfecção [GLAZE (1987)] [EVANS (1972)].

Os metais de transição, por exemplo, na presença de ozônio são levados a seus mais altos estados de oxidação, nos quais, em geral, são menos solúveis em meio aquoso e podem ser removidos por filtração. As equações (3.1) e (3.2) exemplificam a capacidade oxidativa do ozônio na precipitação do ferro metálico sob a forma de hidróxido insolúvel.

$$
\begin{aligned}
2 \mathrm{Fe}^{2+}+\mathrm{O}_{3}+\mathrm{H}_{2} \mathrm{O} & \longrightarrow 2 \mathrm{Fe}^{3+}+\mathrm{O}_{2}+2 \mathrm{OH}^{-} \\
\mathrm{Fe}^{3+}+3 \mathrm{H}_{2} \mathrm{O} & \longrightarrow \mathrm{Fe}(\mathrm{OH})_{3} \downarrow+3 \mathrm{H}^{+}
\end{aligned}
$$

Além do ferro, outros elementos como chumbo, prata, cádmio, mercúrio, níquel, amônia e ânions nitrogenados, como nitrito, cianeto, cianato e tiocianato, podem ser removidos pela adição de ozônio, respeitadas certas condições reacionais.

Os fatores limitantes no processo de desinfecção estão associados em grande parte à presença de matéria orgânica em suspensão, cuja cinética de reação com ozônio em muitos casos é mais favorável, criando rotas de competição.

Desse modo, substâncias como ferro e manganês, gás sulfídrico e turbidez devido a presença de compostos orgânicos e inorgânicos, incluindo os nitrogenados, podem interferir sensivelmente na eficiência da desinfecção pois concorrendo com os microrganismos pelo ozônio disponível [JOHNSON (1975)]. 


\subsubsection{Gerador de Ozônio}

Dentre as técnicas empregadas na geração de ozônio destaca-se o processo denominado descarga corona. O método se baseia na conversão de moléculas de oxigênio em ozônio pela passagem do $\mathrm{O}_{2}$ entre dois eletrodos aos quais é aplicada tensão entre 8 e $20 \mathrm{kV}$.

Como fonte de oxigênio pode ser utilizado o próprio ar atmosférico pressurizado, nesse caso, fornecendo cerca de $2 \%$ em peso. Frações maiores podem ser atingidas com a introdução de oxigênio puro ou ainda com a substituição de parte do ar comprimido por oxigênio. É importante ressaltar que em todos os casos a elevada instabilidade do gás ozônio exige sua produção nas proximidades da unidade onde será consumido [MAUSTELLER (1989)] [GLAZE (1987)].

Os elétrons gerados na descarga corona possuem energia interna suficiente para provocar a dissociação de moléculas de oxigênio em seus átomos constituintes, como ilustra a equação (3.3).

$$
\mathrm{O}_{2}+e(\uparrow \text { energia }) \longrightarrow 2 \mathrm{O} \cdot+e(\downarrow \text { energia })
$$

Uma vez livres, os átomos de oxigênio, altamente instáveis, reagem prontamente com novas moléculas de oxigênio para formar ozônio gasoso, como descreve a equação (3.4) [WEF (1996)] [EVANS (1972)].

$$
\mathrm{O} \cdot+\mathrm{O}_{2} \longrightarrow \mathrm{O}_{3}
$$

A limitação do método descarga corona se deve, particularmente, a aspectos operacionais como aumento da temperatura, diminuição da concentração de $\mathrm{O}_{2}$ na entrada do equipamente e baixa eficiência de distribuição de energia nos eletrodos [MAUSTELLER (1989)].

Embora o elevado consumo de energia, na prática apenas cerca de 5\% do valor global é efetivamente utilizado na geração de ozônio, sendo a maior parte dissipada na forma de calor e energia luminosa [MAUSTELLER (1989)]. 


\subsubsection{Câmara de Ozonização}

O contato entre as fases gasosa (ozônio) e líquida (efluente) ocorre na câmara de ozonização, onde são promovidas reações de desinfecção e oxi-redução. Embora a variedade de configurações, pode-se destacar o método de difusão convencional de bolhas, mistura por turbina, injeção e mistura estática e coluna empacotada.

O projeto da unidade de contato deve observar aspectos como velocidade e dimensão das bolhas formadas, modo de distribuição na fase líquida (difusão, injeção externa, turbina), altura do tanque, direção do fluxo gás-líquido (contracorrente, no mesmo sentido), concentração de ozônio, temperatura e pH, tempo de contato e modo de coleta do gás ozônio excedente, isto é, não consumido na câmara de reação [GLAZE (1987)].

Na prática, um dos maiores desafios é evitar a formação de regiões de curtocircuito hidráulico, isto é, caminhos preferenciais de escoamento do gás $\mathrm{O}_{3}$, pois, nestes casos, o tempo de retenção efetivo é significativamente inferior ao teórico, o que reduz o tempo de exposição do microrganismo ao agente de inativação ${ }^{1}$.

Em unidades reais de tratamento, o sistema mais comumente empregado utiliza dispersão ascendente do gás através de bolhas com introdução da fase líquida em contra-corrente, em tanque cilíndrico de dimensão variável [WEF (1996)].

\subsubsection{Transferência de Massa Gás-Líquido}

Não obstante a importância das considerações anteriormente mencionadas, o desempenho global da desinfecção depende em grande parte do contato efetivo entre os microrganismos presentes e as moléculas de ozônio disponíveis.

Embora altamente solúvel em água, a concentração de ozônio na fase gasosa está limitada à sua baixa pressão parcial na saída do equipamento gerador (2 a $3 \%$ em peso).

\footnotetext{
${ }^{1}$ WEF (1996) relata experimentos que confirmam o aumento do número de bactérias coliforme sobreviventes à ozonização em sistemas com rotas preferenciais de circulação do ozônio.
} 
Além da concentração, parâmetros como temperatura e pH do efluente, variações na velocidade de agitação da mistura e vazão do gás de alimentação interferem consideravelmente na taxa de transferência de massa [MAUSTELLER (1989)] [WEF (1996)].

As representações gráficas indicadas nas Figuras 3.2(a) e 3.2(b) ilustram o efeito das variáveis temperatura e pH do meio no potencial de solubilidade do gás ozônio.

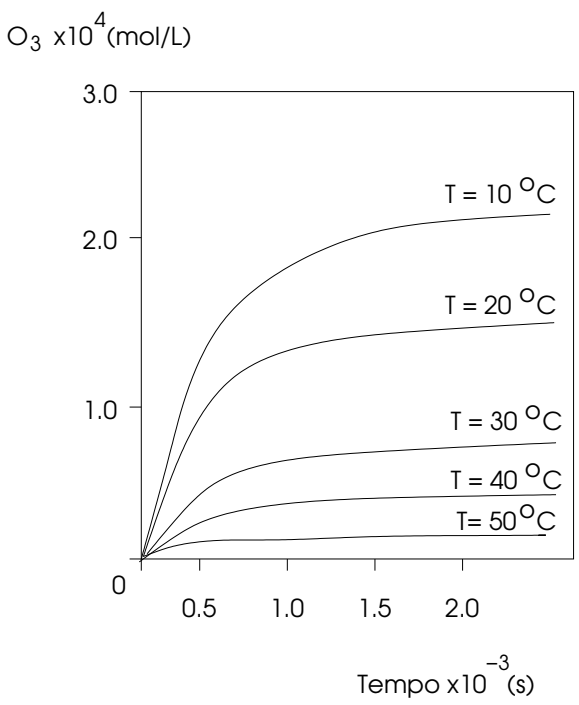

(a) Influência da temperatura.

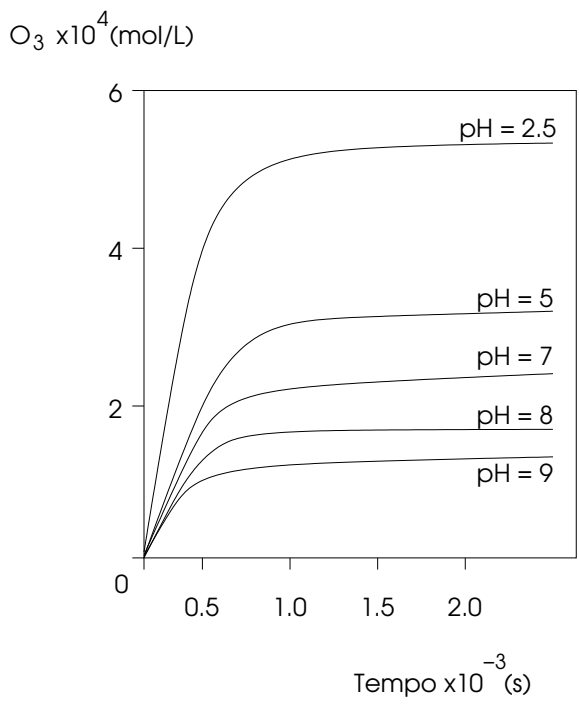

(b) Influência do $\mathrm{pH}$.

Figura 3.2: Efeito dos parâmetros pH e temperatura na solubilidade do gás ozônio em água. Fonte: SOTELO et al. (1989)

Segundo esses dados, a diminuição da temperatura e do pH eleva a solubilidade do gás favorecendo as reações de oxidação e desinfecção pelo aumento da concentração de ozônio disponível [MAUSTELLER (1989)] [SOTELO et al. (1989)] [WEF (1996)].

Comportamento inverso é observado na análise da variação da vazão de ozônio aplicado (Figura 3.3). Neste caso, a diminuição da taxa de fluxo implica na redução da fração de ozônio presente na fase gasosa, diminuindo, portanto, a concentração de ozônio no meio líquido [SOTELO et al. (1989)]. 


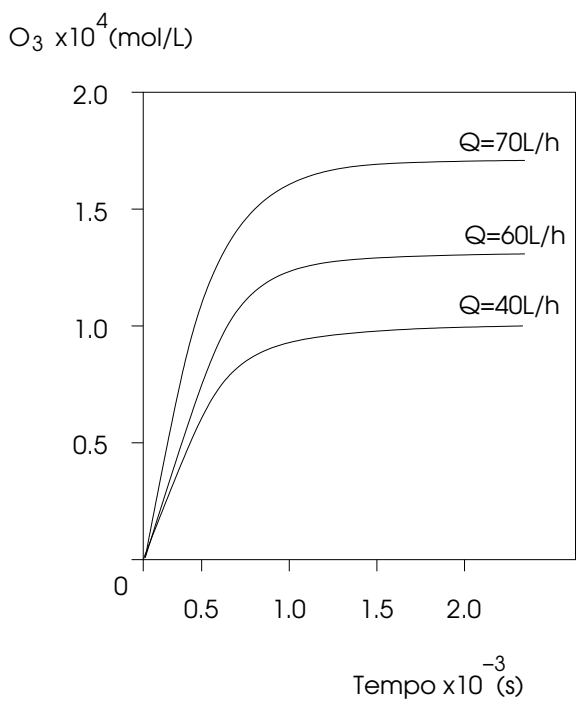

Figura 3.3: Efeito da vazão do gás de alimentação na solubilidade do ozônio em água. Fonte: SOTELO et al. (1989)

Entretanto, a medida que a vazão do gás atinge valores muito elevados a turbulência gerada pela própria dispersão das bolhas formadas dificulta ou mesmo impede a permanência do gás, isto é, reduz sua solubilidade. Na prática, a condição ideal de operação dependerá, dentre outros fatores, do volume de efluente tratado, da configuração da câmara de reação e do sistema de transferência gás-líquido [SOTELO et al. (1989)].

Investigações realizadas por CHIANG et al. (1999) em reator de coluna com dispersão gasosa em contra-corrente confirmam a influência da vazão de gás na concentração de ozônio dissolvido. As bolhas produzidas no difusor devem possuir dimensão mediana para que sejam favorecidas as reações com microrganismos, substâncias orgânicas e inorgânicas. Além disso, a desinfecção é beneficiada por velocidades menores de ascensão das bolhas pois aumentam sua permanência na câmara de ozonização [WEF (1996)].

Nesses casos, a otimização pode ser alcançada em reator pressurizado ou sistema com elevada coluna líquida acima do difusor, prolongando o período de contato entre as bolhas e o líquido. A altura ideal de coluna deve estar entre 3,5 e 5,5m pois acima deste limite a pressão exercida pela massa de água sobre o 
sistema de injeção de gás pode torná-lo inoperante [MAUSTELLER (1989)].

\subsubsection{Análise das Fases Líquida e Gasosa}

O monitoramento das fases líquida e gasosa é fundamental para se estimar a concentração de ozônio efetivamente consumido nas reações de oxidação da matéria orgânica e inativação de microrganismos diversos, definida como demanda química. Conseqüentemente, a determinação da demanda de agente inativante requerida na unidade de desinfecção analisada permite otimizar a dosagem de ozônio aplicado, reduzindo, assim, seu custo.

As técnicas analíticas comumente empregadas na avaliação da concentração de ozônio nas fases líquida e gasosa estão relacionadas na Tabela 3.3.

Tabela 3.3: Métodos para determinação da concentração de $O_{3}$.

\begin{tabular}{c}
\hline Fase líquida \\
Oxidação iodométrica \\
Cristal leuco-violeta \\
Dietil-p-fenilenediamina (DPD) \\
Indigo-blue \\
Cromo-violeta K \\
Absorção de radiação \\
Fase gasosa \\
Absorção ultravioleta \\
Quimioluminescência \\
Colorimetria \\
Iodometria
\end{tabular}

$\mathrm{Na}$ fase líquida, todavia, a elevada instabilidade do gás pode dificultar sua determinação, visto que as técnicas em uso promovem reações de oxi-redução nãoseletivas envolvendo tanto moléculas de ozônio quanto outros agentes oxidantes presentes no efluente ${ }^{2}$, o que resulta, nesses casos, no aumento aparente de fração

\footnotetext{
${ }^{2}$ Tais como os intermediários reativos formados na decomposição do $\mathrm{O}_{3}$ que ali permanecem, ou ainda outros compostos oxidantes dissolvidos.
} 
residual real [STANLEY \& JOHNSON (1991)] [WEF (1996)].

A concentração de ozônio efetivamente consumida em um dado sistema de desinfecção é estabelecida a partir da equação (3.5), expressa em mg de $\mathrm{O}_{3} / \mathrm{L}$. Nela, o elemento identificado como Off-gas representa a fração de ozônio excedente, isto é, a massa gasosa que percorre a câmara de ozonização sem ser absorvida.

$$
\text { Dose consumida }=(\text { Dose calculada })-\left(0_{3} \text { residual }\right)-(\text { Off-gas })
$$

\subsubsection{Mecanismo de Decomposição}

As reações de decomposição podem seguir dois mecanismos distintos: 1) via oxidação direta de espécies dissolvidas no meio líquido ou 2) via oxidação indireta dessas espécies. O mecanismo predominante dependerá, sobretudo, das características físico-químicas do efluente ozonizado.

No primeiro caso, a oxidação envolve reações seletivas, as quais atuam diretamente em grupos funcionais específicos presentes no material alvo, como compostos orgânicos e estruturas bioquímicas. Relativamente mais lentas, estas reações são mais efetivas na inativação de indicadores patogênicos quando comparadas ao processo indireto [STAEHELIN \& HOIGNÉ (1985)].

No mecanismo de decomposição por via indireta, por outro lado, surgem reações adicionais envolvendo oxidantes secundários, intermediários formados a partir do ozônio molecular, altamente instáveis, que reagem prontamente com as várias substâncias orgânicas e inorgânicas encontradas no efluente. Estas reações podem ser divididas em três fases: iniciação, propagação e inibição [AWWA (1991)] [STAEHELIN \& HOIGNÉ (1985)] [WEF (1996)].

A iniciação é a fase determinante. Nela, iniciadores de reação, como por exemplo íons hidroxila $\left(\mathrm{OH}^{-}\right)$, convertem o $\mathrm{O}_{3}$ em ânions superóxido $\left(\mathrm{O}_{2}^{-} \cdot\right)$ e radicais hidroperoxil ${ }^{3}\left(\mathrm{HO}_{2} \cdot\right)$, que por sua vez formam os íons radicalares $\left(\mathrm{O}_{3}^{-} \cdot\right)$, conforme descreve as equações (3.6) e (3.7).

\footnotetext{
${ }^{3}$ Coexistentes em equilíbrio ácido-base.
} 


$$
\begin{aligned}
\mathrm{O}_{3}+\mathrm{OH}^{-} & \longrightarrow\left[\mathrm{O}_{2}^{-} \cdot \leftrightarrows \mathrm{HO}_{2} \cdot\right] \\
\mathrm{O}_{2}^{-} \cdot+\mathrm{O}_{3} & \longrightarrow \mathrm{O}_{3}^{-} .
\end{aligned}
$$

Na seqüência são formados os radicais livres, principais responsáveis pela oxidação da matéria orgânica e inorgânica por sua elevada instabilidade, em particular a hidroxila radicalar (OH·) [STAEHELIN \& HOIGNÉ (1985)] [AWWA (1991)] [WEF (1996)].

A equação (3.8) ilustra as transformações envolvidas nesta etapa.

$$
\mathrm{O}_{3}^{-} \cdot+\mathrm{H}^{+} \longrightarrow \mathrm{HO}_{3} \cdot \longrightarrow \mathrm{OH} \cdot+\mathrm{O}_{2}
$$

Entretanto, o radical $\mathrm{OH}$ - apenas será formado enquanto substâncias promotoras, isto é, elementos regeneradores de superóxidos, estiverem presentes em concentrações adequadas.

A etapa denominada inibição tem início quando íons superóxido são consumidos e não são regenerados. Vários compostos orgânicos e inorgânicos podem agir como inibidores, como por exemplo carbonato $\left(\mathrm{CO}_{3}^{2-}\right)$ e bicarbonato $\left(\mathrm{HCO}_{3}^{-}\right)$ dissolvido.

Em elevadas concentrações, estes compostos podem mesmo interromper totalmente as reações em cadeia, reduzindo consideravelmente a capacidade de oxidação do ozônio. Na Tabela 3.4 estão relacionadas algumas espécies tipicamente iniciadoras, promotoras e inibidoras de reações em cadeia pelo mecanismo indireto de decomposição.

Por outro lado, em unidades de tratamento destinadas a desinfecção de esgoto sanitário a presença de espécies como $\mathrm{CO}_{3}^{2-}$ e $\mathrm{HCO}_{3}^{-}$estimula a decomposição do ozônio pelo mecanismo direto e, portanto, favorece as reações de inativação [GLAZE (1987)] [STAEHELIN \& HOIGNÉ (1985)]. 
Tabela 3.4: Espécies iniciadoras, promotoras e inibidoras de reações em cadeia.

\begin{tabular}{|c|c|c|}
\hline Iniciadores & Promotores & Inibidores \\
\hline $\mathrm{OH}^{-}$ & $\mathrm{R}_{2}-\mathrm{CH}-\mathrm{OH}$ & $\mathrm{CH}_{3}-\mathrm{CO}-\mathrm{O}^{-}$ \\
\hline $\mathrm{H}_{2} \mathrm{O}_{2} / \mathrm{HO}_{2}^{-}$ & $\operatorname{aril}-(\mathrm{R})$ & alquil- $(\mathrm{R})$ \\
\hline húmicos & húmicos & húmicos \\
\hline $\begin{array}{l}\mathrm{Fe}^{2+} \\
\text { radiacão UV }\end{array}$ & $\mathrm{O}_{3}$ & $\mathrm{HCO}_{3}^{-} / \mathrm{CO}_{3}^{2-}$ \\
\hline
\end{tabular}

A fase inibidora da decomposição do ozônio pode ser exemplificada pela seqüência indicada na equação (3.9), onde radicais hidroxila são consumidos rapidamente do meio pela simples transferência de elétrons.

$$
\mathrm{HCO}_{3}^{-}+\mathrm{OH} \cdot \longrightarrow \mathrm{OH}^{-}+\mathrm{HCO}_{3}
$$

Os modelos que descrevem as etapas de iniciação, propagação e inibição, na decomposição do ozônio por via indireta, podem ser visualizados na representação indicada pela Figura 3.4.

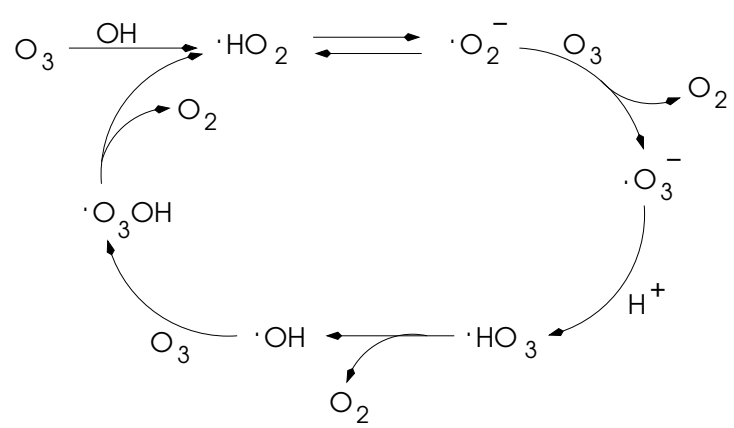

Modelo Staehelin, Bader e Hoigné

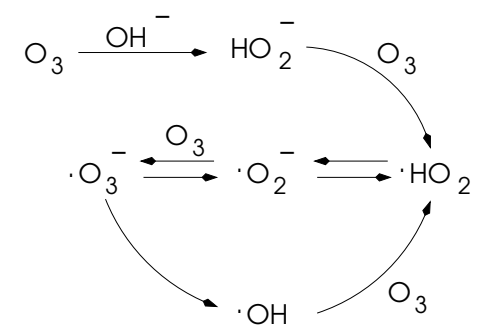

Modelo Tomiyasu, Fukutomi e Gordon

Figura 3.4: Mecanismo de decomposição indireto do ozônio molecular. Fonte: WEF (1996) 


\subsubsection{Mecanismo de Inativação}

A inativação de microrganismos indicadores de águas contaminadas envolve diversos fenômenos heterogêneos bastante complexos, os quais incluem a transferência de massa do agente oxidante para o interior do citoplasma, absorção dessa massa pela célula atingida e ocorrência de reações bioquímicas específicas. Além disso, a taxa de transporte do material oxidante pode ser afetada por inúmeras reações intra e extracelulares com diferentes biomoléculas.

Portanto, a inatividade de organismos sujeitos à ozonização está intrinsecamente associada a uma série de eventos necessários para que seus constituintes vitais sofram níveis de destruição irreversíveis e letais.

Alguns autores acreditam que o mecanismo de ação do ozônio está relacionado à capacidade oxidante dos radicais livres formados ${ }^{4}$. Hábeis para modificar a permeabilidade da membrana celular, facilmente atingem o interior da célula podendo atuar livremente sobre as bases purina e pirimidina ali encontradas. Por fim, estas bases podem sofrer rompimento de ligações químicas, levando a alterações microbiológicas, que em muitos casos resultam em lesões irreversíveis e letais ao microrganismo [BITTON (1994)] [AWWA (1991)].

Segundo WEF (1996), a ação da molécula de ozônio na quebra de ligações nitrogênio-carbono entre açúcares e bases nitrogenadas, além de ligações de hidrogênio no DNA, induz à polimerização de cromossomos e o rompimento de ligações fosfato em açúcares.

Pesquisadores têm reportado ainda que proteínas e lipídios insaturados presentes na membrana celular microbiana são alvos preferenciais ao ataque do ozônio. Neste caso, ligações químicas são rompidas ao longo da molécula de DNA, eliminando a célula atingida [MAUSTELLER (1989)].

Para os vírus, o mecanismo de inativação não é bem compreendido. Alguns estudiosos acreditam ser o ozônio responsável pela destruição de proteínas essen-

\footnotetext{
${ }^{4}$ Entretanto, no esgoto sanitário a inativação é favorecida pela reação direta com o ozônio molecular, mais seletiva que as espécies radicalares STAEHELIN \& HOIGNÉ (1985).
} 
ciais à sua sobrevivência, enquando outros mencionam a ação conjunta no RNA viral [WEF (1996)].

\subsubsection{Dose de Ozônio}

O desempenho global da ozonização depende em grande parte da eficiência de geração e transferência do gás para o efluente. A concentração de ozônio deve ser, portanto, estimada de modo a atender a demanda das rápidas reações de oxidação com espécies orgânicas e inorgânicas, bem como promover as reações com as várias espécies de microrganismos patogênicos ali presentes.

Além da fração de ozônio disponível, o tempo de contato entre o microrganismo e o agente oxidante é outro importante fator no processo de desinfecção. A concentração de ozônio transferida para o efluente por um determinado intervalo de tempo é definida como dosagem necessária para se alcançar o nível de inativação desejado [AWWA (1991)] [WEF (1996)].

A influência dos parâmetros concentração de ozônio aplicado e tempo de exposição no índice de protozoários Giardia lamblia eliminados está ilustrada na Figura 3.5 [BITTON (1994)] [WEF (1996)].

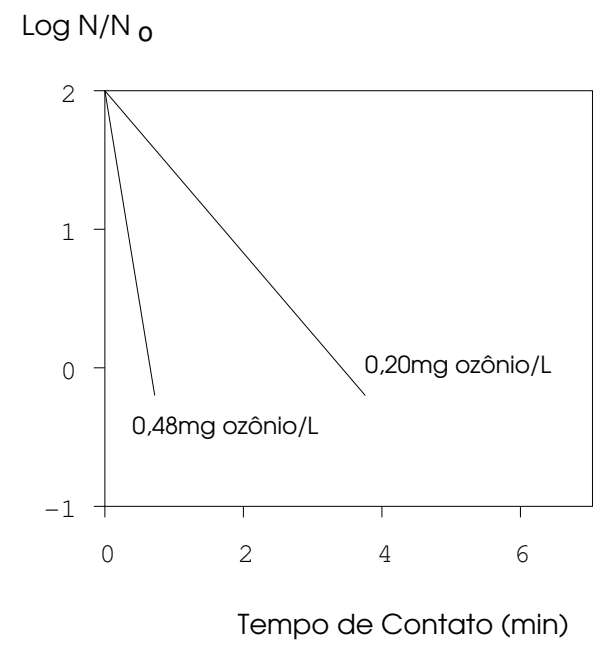

Figura 3.5: Efeito das variáveis tempo de contato e concentração de $\mathrm{O}_{3}$ na fração de Giardia lamblia sobrevivente. Fonte: BITTON (1994) 
A literatura científica tem reportado grande variedade de experimentos envolvendo gás ozônio como agente de desinfecção. Sua eficácia tem sido comprovada na inativação de bactérias coliformes, em efluentes secundários, cistos de Giardia lamblia e Cryptosporidium parvum, e vírus como MS2 colifago, extremamente resistente a outros métodos de desinfecção, dentre outras espécies [WEF (1996)].

\subsection{Radiação Ultravioleta}

A aplicação da energia solar como mecanismo para destruição de células microbianas teve origem em 1877 através de estudos realizados por DOWNES e BLUNT [KOLLER (1958)].

Em meados do século XX, fontes artificiais de radiação emitida no comprimento de onda dos raios UV passaram a ser utilizadas na inativação de espécies patogênicas no tratamento de água de abastecimento, e, mais tarde, esgoto sanitário [BITTON (1994)] [LOGE et al. (1996)]. Atualmente, inúmeras instalações localizadas principalmente na Europa, em particular na França, utilizam-se desta tecnologia no tratamento de águas de abastecimento e residuárias.

\subsubsection{Propriedades}

A radiação ultravioleta compreende a faixa do espectro eletromagnético entre os raios-X e a luz visível, com limites situados entre os comprimentos de onda 40 e 400nm, como ilustra o esquema da Figura 3.6.

De acordo com a teoria desenvolvida por Einstein em 1905, a intensidade de energia emitida por uma fonte qualquer é definida como sendo inversamente proporcional ao seu comprimento de onda. Assim, comprimentos de onda mais baixos na escala do espectro eletromagnético provocam perturbações mais intensas quando absorvidos [BRAUN et al. (1986)]. 


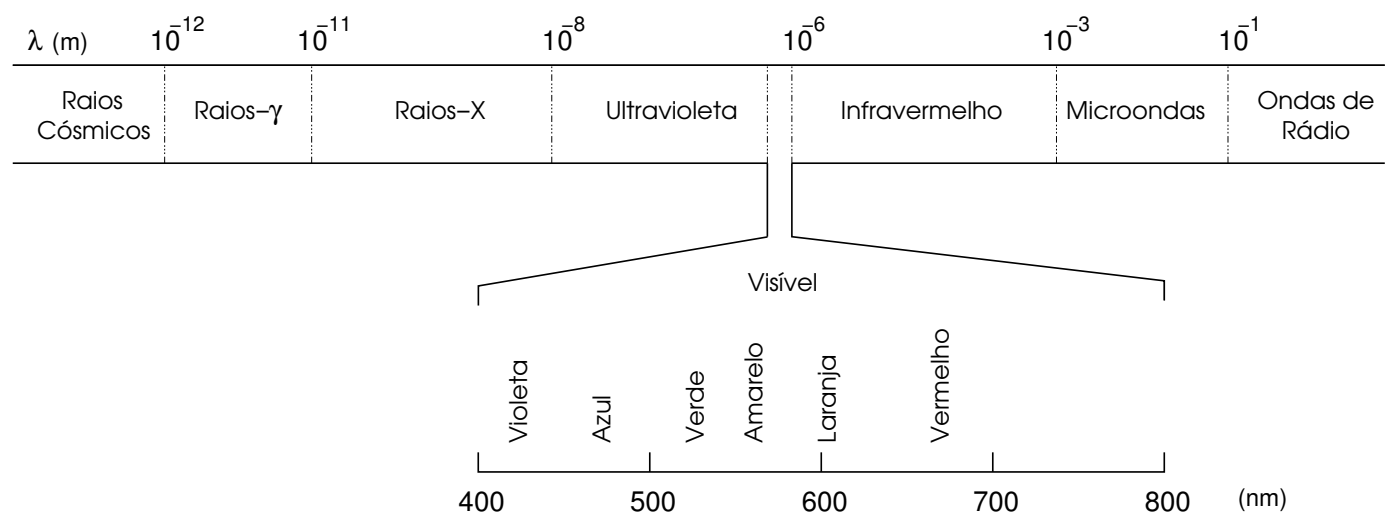

Figura 3.6: Espectro eletromagnético. Fonte: BRAUN et al. (1986)

Portanto, quando uma estrutura biológica absorve fótons de luz sua energia interna aumenta proporcionalmente à intensidade de radiação recebida. Conseqüentemente, dependendo do comprimento de onda emitido, a energia a ele associada pode provocar alterações bioquímicas, reversíveis ou não, nas moléculas atingidas.

A radiação emitida na faixa do microondas estimula movimentos rotacionais na molécula. Similarmente, o infravermelho e a luz visível promovem vibração molecular, devido ao aumento da energia do orbital. Os raios-X e a radiação ultravioleta de curto comprimento de onda provocam, em geral, o rompimento de ligações químicas e a ionização da molécula [BRAUN et al. (1986)].

Com raras exceções, os efeitos da radiação UV, em sistemas biológicos, se acentua entre os limites 190 e 380nm, atingindo intensidade máxima próximo a $254 \mathrm{~nm}$.

A energia irradiada em $253,7 \mathrm{~nm}$ fornece o equivalente a $472,3 \mathrm{~kJ} /$ einstein, valor este suficientemente elevado para provocar mudanças fotobioquímicas. $\mathrm{Na}$ Tabela 3.5 estão relacionados alguns importantes grupamentos funcionais encontrados em sistemas bioquímicos assim como suas correspondentes energias de ligação [WEF (1996)]. 
Tabela 3.5: Energia de ligação para importantes grupos funcionais.

\begin{tabular}{cc}
\hline Ligação & Energia $(\mathrm{kJ} / \mathrm{mol})$ \\
\hline $\mathrm{N}-\mathrm{H}$ & 389,3 \\
$\mathrm{O}-\mathrm{H}$ & $460,5-464,7$ \\
$\mathrm{C}-\mathrm{H}$ & $401,9-414,5$ \\
$\mathrm{C}-\mathrm{C}$ & $347,5-355,9$ \\
$\mathrm{C}-\mathrm{N}$ & $288,9-314,0$ \\
$\mathrm{C}=\mathrm{O}$ & $724,3-757,8$ \\
$\mathrm{C}=\mathrm{C}$ & $611,2-632,2$ \\
\hline
\end{tabular}

Fonte: WEF (1996)

Segundo WEF (1996), os ácidos desoxirribonucleico (DNA) e ribonucleico (RNA), assim como as proteínas, são os principais responsáveis pela absorção de radiação UV na faixa entre 240 a 260nm, particularmente em $254 \mathrm{~nm}$.

\subsubsection{Fonte de Radiação UV}

A radiação ultravioleta emitida em $254 \mathrm{~nm}$ pode ser produzida artificialmente com o uso de lâmpadas específicas. Para o modelo mais comum, seu funcionamento se baseia no deslocamento de elétrons entre dois eletrodos separados por uma camada gasosa ou vapor. Outros modelos utilizam ainda fontes incandescentes, porém, a emissão de ultravioleta, nestes casos, é significativamente inferior [WEF (1996)] [PHILLIPS (1983)].

Para efeito de destruição das células microbiana, as lâmpadas de baixa pressão de vapor de mercúrio, denominadas comercialmente lâmpadas germicidas, são particularmente indicadas. Cerca de $85 \%$ da energia luminosa efetiva, isto é, aproximadamente 50\% da potência nominal, é irradiada em 254nm [WEF (1996)].

Estas lâmpadas são fabricadas em quartzo, ou material de transmitância semelhante, que permite máxima irradiação. Seu interior é preenchido com uma mistura gasosa contendo vapor de mercúrio e argônio. Estes gases são espe- 
cialmente recomendados pois além de inertes ao contato com os eletrodos e o invólucro da lâmpada são também essencialmente emissores de radiação na faixa dos raios ultravioleta [PHILLIPS (1983)].

Embora possuam vida útil longa, as lâmpadas germicidas na prática sofrem desgaste devido a fatores como variação da temperatura, oscilação da tensão na rede elétrica e o próprio consumo dos eletrodos, podendo limitar seu desempenho [WEF (1996)] [KOLLER (1958)].

\subsubsection{Câmara de Contato}

A câmara de reação, ou reator fotoquímico, promove o contato entre a radiação ultravioleta e o efluente. A configuração da câmara, em sistemas de desinfecção, inclui o estudo da geometria adequada e o posicionamento da fonte luminosa.

Os reatores fotoquímicos comumente empregados no tratamento de esgoto sanitário podem ser classificados segundo: (1) o modo de fixação da lâmpada imersa no efluente ou sem manter contato com ele; (2) a orientação da lâmpada — disposta horizontal ou verticalmente ao fluxo líquido.

O esquema indicado na Figura 3.7(a) exemplifica a configuração do tipo anular submersa com fonte luminosa e reator cilíndrico concêntrico e coaxial. A parede interna da câmara de reação deve ser revestida com material que alcance elevado índice de reflexão para o comprimento de onda de interesse. Além disso, é necessária a limpeza periódica da lâmpada para retirada de material nela depositado [KOLLER (1958)].

Na câmara representada pela Figura 3.7(b), não há qualquer contato entre o efluente e a fonte de radiação, ao contrário, esta é mantida na cúpula da câmara distante alguns centímetros do líquido. Neste caso, o refletor pode ser paralelepípedo reto-retangular ou parabólico, embora pouco usual ${ }^{5}$ [DANIEL (1993)].

\footnotetext{
${ }^{5} \mathrm{O}$ cálculo da intensidade de radiação em câmaras com configuração parabólica é demasiadamente complexo, principalmente em sistemas com mais de uma lâmpada [DANIEL (1993)].
} 
Lâmpada submersa (corte longitudinal)

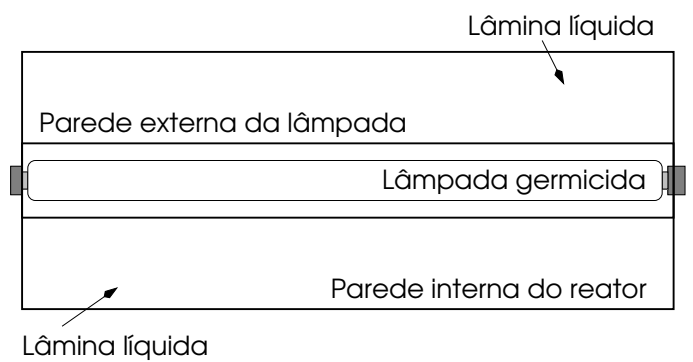

Lâmpada submersa (vista frontal)

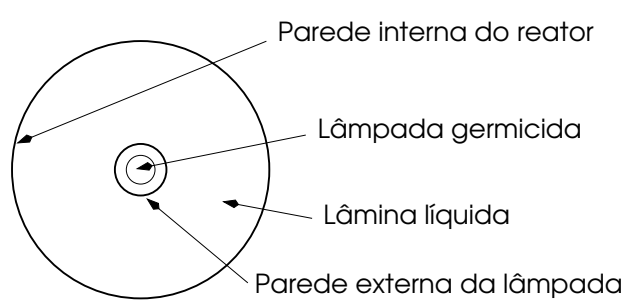

(a) Configuração anular com lâmpada submersa.

Lâmpada emersa (corte longitudinal)

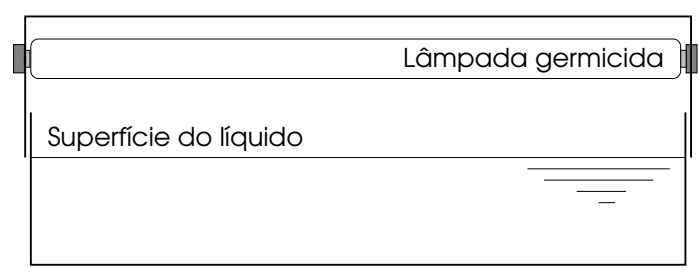

Lâmpada emersa (corte transversal)

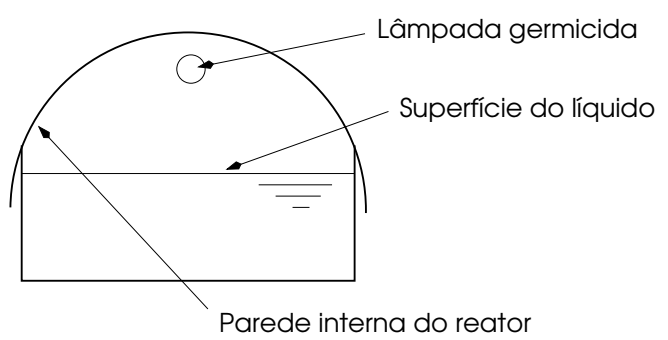

(b) Configuração parabólica com lâmpada emersa.

Figura 3.7: Representação simplificada de câmaras de contato projetadas para utilização de radiação UV. Fonte adaptada: BRAUN et al. (1986)

Além dos aspectos descritos, o projeto do reator fotoquímico deve incluir o mecanismo de agitação do meio líquido para homogeneizá-lo e a escolha do material de revestimento, que deve ser resistente à corrosão em se tratando do esgoto sanitário, e eficiente refletor de raios UV [PHILLIPS (1983)].

Variações na configuração de unidades fotoquímicas têm sido amplamente divulgadas na literatura científica [ANDREADAKIS et al. (1999)] [HO et al. (1998)] [BRAUN et al. (1986)].

Nos Estados Unidos, por exemplo, a maior parte das unidades de desinfecção de grande porte destinadas ao tratamento de esgoto, atualmente em operação, utilizam o processo denominado canal aberto (open-channel). O conceito consiste na 
implantação de dois reservatórios abertos unidos entre si por tubulações, adequadamente projetadas, contendo diversas lâmpadas de alta intensidade, dispostas paralelamente ao escoamento do efluente, o qual é transferido de um reservatório para o outro passando pelo sistema de irradiação [WEF (1996)].

\subsubsection{Transmissão da Radiação}

Quando um feixe de luz atravessa um meio qualquer, uma fração constante da radiação emitida é por ele absorvida na proporção inversa da distância percorrida. Desse modo, a intensidade de energia radiante diminui a medida que aumenta a espessura da lâmina líquida [KOLLER (1958)].

A intensidade com que a radiação é assimilada dependerá em grande parte de certas características do meio, tais como concentração de material particulado, espessura da camada líquida percorrida, temperatura, e a própria eficiência de emissão da lâmpada.

O mecanismo que regula o modo de dispersão dos raios ultravioleta incidentes em uma dada massa líquida é estabelecido através da lei de Beer-Lambert, onde:

$$
I=I_{0} \cdot e^{-a \cdot L}
$$

$I$ : intensidade de radiação após percorrer a distância $L\left(\mathrm{~mW} / \mathrm{cm}^{2}\right)$;

$I_{0}$ : intensidade de radiação na superfície do líquido $\left(\mathrm{mW} / \mathrm{cm}^{2}\right)$;

$a$ : coeficiente de extinção molar $^{6}$ (mol/L.cm);

$L$ : espessura da lâmina líquida $(\mathrm{cm})$.

Definida pela expressão (3.11), a fração $I / I_{0}$ é função da transmitância do meio e pode ser reescrita em termos da absorbância pela relação de proporcionalidade estabelecida na equação (3.12) [WEF (1996)].

$$
\frac{I}{I_{0}}=T=e^{(-a . L)}
$$

\footnotetext{
${ }^{6}$ Seu valor dependerá do índice de absorbância do meio, da temperatura e do comprimento de onda emitido.
} 


$$
A=-\log T
$$

$A$ : absorbância (adimensional);

$T$ : transmitância (adimensional).

A combinação das equações (3.11) e (3.12) resulta na expressão (3.13), cuja absorbância $A$, para a amostra irradiada, pode ser determinada analiticamente por espectrofotometria em comprimento de onda $254 \mathrm{~nm}$.

Visto que as leituras de absorbância utilizam cubeta onde $L$ é igual a $1 \mathrm{~cm}$, o coeficiente $a$ pode ser calculado substituindo o valor da absorbância na equação (3.14) [WEF (1996)] [DANIEL (1989)].

$$
\begin{aligned}
& A=-\log e^{(-a \cdot L)} \\
& a=2,303 . A
\end{aligned}
$$

Finalmente, quando a equação (3.10) é integrada obtem-se a intensidade média de radiação incidente na lâmina líquida $L$, conforme equação (3.15).

$$
I_{M}=\frac{I_{0}}{2,303 A \cdot L}\left(1-e^{-2,303 A \cdot L}\right)
$$

$I_{M}$ : intensidade média de radiação $\left(\mathrm{mW} / \mathrm{cm}^{2}\right)$.

Segundo KOLLER (1958), em sistemas fotoquímicos com lâmpadas externas, isto é, sem contato com o efluente, a intensidade de energia absorvida pelo ar é desprezível pois normalmente são utilizadas distâncias pequenas entre a fonte luminosa e a lâmina líquida.

\subsubsection{Determinação da Intensidade de Energia Radiante}

Embora a intensidade de radiação não seja distribuída uniformemente em toda a extensão da lâmpada, seu valor médio pode ser estimado pela aplicação de técnicas particulares, as quais utilizam princípios físicos ou químicos de detecção, diferenciados entre si pelo método de análise adotada. 
No primeiro caso o método se baseia na leitura direta da intensidade de energia transmitida pela lâmpada para o fotodetector, enquanto no segundo são introduzidos reagentes específicos para produção de reações químicas fotossensíveis, cuja mudança de coloração da solução irradiada resultante determina a capacidade de emissão da lâmpada [PHILLIPS (1983)].

Os principais métodos de determinação da intensidade de emissão da lâmpada germicida na faixa dos raios UV estão relacionados na Tabela 3.6 [WEF (1996)].

Tabela 3.6: Métodos para determinação da intensidade média da lâmpada.

\begin{tabular}{l}
\hline Técnicas em uso \\
Radiometria física \\
Actinometria \\
Somatória de fontes pontuais ${ }^{a}$ \\
\hline [a] Apenas citado na literatura [WEF (1996)].
\end{tabular}

\section{Radiometria}

Para se estimar a capacidade média de irradiação da fonte luminosa por radiometria física, detectores instalados em circuitos eletrônicos específicos captam a energia radiante e transformam-na em sinal elétrico, cuja intensidade varia em função do grau de radiação recebida.

A técnica é composta, basicamente, pelo selector de radiação e o detector fotossensível. O sistema seletor do equipamento, um filtro por exemplo, permite o ajuste do comprimento de onda desejado, impedindo o acesso dos demais por absorção ou dispersão da radiação desconsiderada.

Os detectores instrumentais em radiometria normalmente utilizam resposta física para sua leitura, como por exemplo a variação da corrente elétrica, tensão ou ainda da temperatura [PHILLIPS (1983)] [BRAUN et al. (1986)]. 


\section{Actinometria}

O princípio de ação do método se apóia na mudança de coloração da solução irradiada pela lâmpada germicida. Essas transformações decorrem da alteração do estado de oxidação da solução actinométrica induzida pela energia associada à radiação ultravioleta.

A solução ferrioxalato de potássio, neste caso, é particularmente recomendada, pois atende aos requisitos básicos necessários [PHILLIPS (1983)].

A reação fotoquímica se inicia com o acionamento da fonte luminosa e a transferência de energia para a solução ferrioxalato de potássio, preparada segundo metodologia descrita em HATCHARD \& PARKER (1956). A energia absorvida, por sua vez, desencadea reações de oxi-redução que induzem a conversão de íons $\mathrm{Fe}^{3+}$ em $\mathrm{Fe}^{2+}$, como mostra a equação (3.16).

$$
2 \mathrm{~K}_{3} \mathrm{Fe}\left(\mathrm{C}_{2} \mathrm{O}_{4}\right)_{3} \longrightarrow 2 \mathrm{FeC}_{2} \mathrm{O}_{4}+3 \mathrm{~K}_{2} \mathrm{C}_{2} \mathrm{O}_{4}+2 \mathrm{CO}_{2}
$$

Por fim, a análise espectrofotométrica em 510nm da amostra irradiada permite determinar a concentração de íons $\mathrm{Fe}^{2+}$ presentes na solução antes e após a emissão de raios UV. Os resultados obtidos são lançados na equação (3.17), a qual estabelece a relação entre dose de radiação emitida pela lâmpada e fração de íons $\mathrm{Fe}^{2+}$ [HARRIS et al. (1987)].

$$
D=\frac{F e_{f}^{2+}-F e_{i}^{2+}}{\Phi_{F e}} \times 4,719.10^{5}
$$

$D$ : Dose de radiação UV $\left(\mathrm{mW} . \mathrm{s} / \mathrm{cm}^{2}\right)$;

$\mathrm{Fe}_{f}^{2+}$ : Concentração molar final de $\mathrm{Fe}^{2+}(\mathrm{mol} / \mathrm{L}) ;$

$\mathrm{Fe}_{i}^{2+}$ : Concentração molar inicial de $\mathrm{Fe}^{2+}(\mathrm{mol} / \mathrm{L})$;

$\Phi_{F e}$ : Rendimento quântico (1,26 íons-grama/einstein);

$4,719.10^{5}$ : Fator de conversão.

Por fim, introduzindo a dosagem na expressão (3.18) ou (3.19), para o tempo de exposição específico, é possível estimar experimentalmente a intensidade de radiação incidente $I_{0}$ em dada superfície de espessura $L$ ou a intensidade média $I_{M}$ distribuída na lâmina líquida, respectivamente [HARRIS et al. (1987)]. 


$$
\begin{gathered}
I_{0}=\frac{D_{i} \cdot L}{t} \\
I_{M}=\frac{D_{e} \cdot L}{t}
\end{gathered}
$$

$D_{i}$ : Dose de radiação UV incidente $\left(\mathrm{mW} . \mathrm{s} / \mathrm{cm}^{2}\right)$;

$D_{e}$ : Dose de radiação UV efetiva $\left(\mathrm{mW} . \mathrm{s} / \mathrm{cm}^{2}\right)$;

$L$ : Espessura da lâmina líquida $(\mathrm{cm})$;

$t$ : Tempo de contato (s).

Segundo HARRIS et al. (1987), para o cálculo da intensidade média são assumidas duas condições necessárias: (1) toda radiação fornecida pela lâmpada corresponde ao comprimento de onda 254nm; (2) o rendimento quântico para $254 \mathrm{~nm}$ é igual a 1,26 íons-grama de $\mathrm{Fe}^{2+} /$ einstein.

\subsubsection{Mecanismo de Inativação}

A energia assimilada por uma estrutura química qualquer pode induzí-la, basicamente, a quatro modos de alteração: rotação, vibração, excitação eletrônica e quebra de ligação ou ionização.

O efeito germicida resultante da absorção de energia depende sobretudo do comprimento de onda da fonte irradiante e da configuração energética das ligações intramoleculares a ela submetidas. Particularmente em sistemas de desinfecção, a energia emitida em 254nm é considerada a mais favorável [SKOOG et al. (1994)].

O mecanismo de inativação se baseia no aumento do estado energético, principalmente em ácidos nucleicos e proteínas essenciais, de modo a induzir o rompimento de ligações químicas ou ainda alterações no código genético, ambos responsáveis pelo comprometimento da célula atingida [BITTON (1994)] [WEF (1996)].

As conseqüências bioquímicas de modificações no RNA celular são menos expressivas devido à sua disponibilidade no interior da célula como RNA mensageiro, transportador e ribossômico, tornando possível sua reconstituição. 
O DNA celular, por outro lado, sendo material genético único, quando alvo de lesões passa a produzir organismos não hábeis à replicação, dificultando ou mesmo impedindo sua reabilitação.

Os danos provocados no DNA se devem sobretudo à dimerização de bases nitrogenadas, predominantemente pirimidinas, e subseqüente rearranjo com bases timina ou citosina vizinhas.

As mutações induzidas por dímeros formados, a menos que possam ser reparadas por enzimas intracelulares específicas, impedem a duplicação do DNA e, conseqüentemente, conduzem o organismo à sua total destruição [PELCZAR et al. (1980)] [WEF (1996)] [BITTON (1994)].

\subsubsection{Dose de Radiação}

A dose de radiação $U V$ incidente em um dado sistema é definida como o produto da intensidade de energia emitida pela lâmpada e o tempo de exposição a ela. A influência deste parâmetro na remoção de microrganismos diversos pode ser acompanhada graficamente ao plotar-se o log da fração sobrevivente, ou $\log \left(\mathrm{N} / \mathrm{N}_{0}\right)$, em função da dose aplicada.

De acordo com LOGE et al. (1996), unidades de desinfecção de esgoto sanitário operam com $\log \left(\mathrm{N} / \mathrm{N}_{0}\right)$ em torno de -3 . Geralmente, essas instalações utilizam número fixo de fontes luminosas, com intensidade de radiação constante e período de exposição variável.

Na Tabela 3.7 estão relacionadas algumas espécies de microrganismos comumente encontradas no esgoto sanitário e as dosagens relativas correspondentes à inativação de $90 \%$. A variação observada na dosagem requerida se deve a variações nas características bioquímicas entre as espécie.

O potencial de inativação das várias reações fotoquímicas envolvidas está sujeito a dois aspectos fundamentais: eficiência de distribuição da radiação UV no meio líquido e as características físico-químicas do efluente, sobretudo quanto à concentração de sólidos suspensos. 
Tabela 3.7: Dose de radiação UV relativa a inativação de $90 \%$.

\begin{tabular}{lc}
\hline Microrganismos & Dose $\left(\mu \mathrm{W} . \mathrm{s} / \mathrm{cm}^{2}\right)$ \\
\hline Bactérias & 3.000 \\
\hline E.coli & 6.000 \\
Mycobacterium tuberculosis & 5.500 \\
Pseudomonas aeruginosa & 2.500 \\
Salmonella typhi & 4.000 \\
Salmonella enteritis & 2.200 \\
Shigella dysenteriae & 1.700 \\
Shigella paradysenteriae & 1.700 \\
Shigella flexneri & 4.500 \\
Staphylococus aureus & 4.400 \\
Streptococcus faecalis & 3.400 \\
Vibrio cholerae & \\
& \\
Vírus & 3.600 \\
Colifago & 3.700 \\
Hepatite A & 5.000 \\
Poliovírus 1 & 8.000 \\
Rotavírus SA 11 & \\
Protozórios & \\
Acanthamoeba castellanii & 35.000 \\
Giardia lamblia & 63.000 \\
Giardia muris & 82.000 \\
\hline
\end{tabular}

[a] Cisto de protozoários. $\quad$ Fonte: BITTON (1994) 
Acredita-se que a presença de material particulado possa dificultar ou, em muitos casos, impedir a ação dos raios ultravioleta devido à formação de agregados partícula-microrganismo, diminuindo seu efeito germicida [OLIVER \& COSGROVE (1975)].

O efeito da concentração de sólidos na inativação de bactérias heterótrofas está exemplificado na Figura 3.8, na qual, sob a mesma dosagem, nota-se a diminuição da fração de organismos sobreviventes ao tratamento com a redução da concentração de sólidos totais de 150mg/L para o intervalo 9 a 20mg/L.

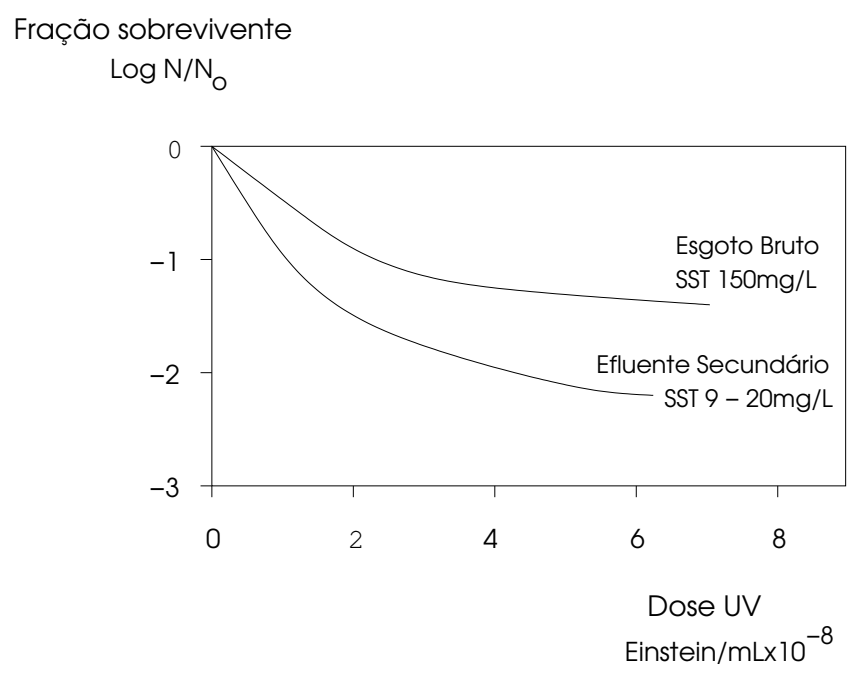

Figura 3.8: Efeito da concentração de sólidos na inativação de bactérias heterótrofas com radiação UV. Fonte: OLIVER \& COSGROVE (1975)

WEF (1996) relata comportamento semelhante para amostras filtradas em membranas de várias porosidades em relação a amostras não filtradas. Resultado similar é mencionado por JANEX et al. (1998) ao descrever a influência da filtração na demanda de energia luminosa requerida para inativar bactérias coliformes fecais.

\subsubsection{Fotorreativação}

Ao longo de seu processo evolutivo, os microrganismos desenvolveram mecanismos bioquímicos próprios capazes de regenerar células lesadas quando forne- 
cida energia particularmente entre 310 e 490nm.

O fenômeno descoberto por Kelner e Dulbecco em 1949 é conhecido como fotorreativação. O processo pode apresentar algumas variações dependendo da estrutura bioquímica atingida e do grau de comprometimento da lesão sofrida [WEF (1996)] [PELCZAR et al. (1980)].

O efeito da fotorreativação pode ser observado na Tabela 3.8 na análise da fração de bactérias Escherichia coli e Streptococcus faecalis remanescentes ao tratamento com radiação ultravioleta [WEF (1996)] [BITTON (1994)].

Tabela 3.8: Influência da fotorreativação na inativação de bactérias $E$. coli e Streptococcus faecalis.

\begin{tabular}{lccc}
\hline & Dose $\left(\mu W . s / \mathrm{cm}^{2}\right)$ & $\log \left(N / N_{0}\right)^{a}$ & $\log \left(N / N_{0}\right)^{b}$ \\
\cline { 2 - 4 } Escherichia coli & 2,5 & $-1,01$ & $-0,22$ \\
& 5,0 & $-4,00$ & $-0,53$ \\
7,5 & $-4,64$ & $-1,29$ \\
& 10,0 & $-5,26$ & $-3,18$ \\
& 15,0 & $-5,98$ & $-3,24$ \\
\cline { 2 - 4 } Streptococcus faecalis & 2,5 & $-0,17$ & $-0,21$ \\
\hline & 5,0 & $-0,80$ & $-0,47$ \\
& 7,5 & $-2,68$ & $-1,33$ \\
& 10,0 & $-4,26$ & $-1,82$ \\
& 15,0 & $-5,41$ & $-3,04$ \\
\hline [a] Sobreviventes na ausência de fotorreativação. Fonte: HARRIS et al. (1987b)
\end{tabular}

A taxa de recuperação dependerá sobretudo de fatores como intensidade da radiação inativante e fotorreativante além das próprias características bioquímicas da espécie lesada. Doses elevadas de radiação comumente aumentam o risco de lesões letais pois acumulam uma série de prejuízos à célula, impedindo seu reestabelecimento [WEF (1996)]. 


\subsection{Sistemas Combinados}

Nos últimos anos, tem surgido crescente interesse na aplicação de processos conjugados destinados ao tratamento de águas de abastecimento e, mais recentemente, residuárias, nos quais sistemas compostos por dois ou mais agentes químicos ou físicos são introduzidos sequencial ou simultaneamente em operações unitárias específicas para promover a oxidação de matéria orgânica e a inativação de indicadores patogênicos. Este procedimento é intitulado processo avançado de oxidação.

A técnica tem se revelado bastante eficiente na decomposição de reagentes químicos perigosos e microrganismos em geral, alcançando níveis aceitáveis de emissão sem a geração de novos sub-produtos, os quais exigiriam nova intervenção tecnológica.

Quando aplicado na oxidação da matéria particulada, o método visa elevar a quantidade de radicais hidroxil ( $\mathrm{OH} \cdot$ ) disponível de modo a favorecer as reações de oxi-redução com os constituintes do efluente em tratamento.

Em efluentes industriais, por exemplo, reações desencadeadas pela ação sinergística da oxidação combinada podem estimular a transformação de compostos potencialmente contaminantes em espécies assimiláveis como $\mathrm{CO}_{2}, \mathrm{H}_{2} \mathrm{O}$ e sais diversos.

De acordo com CHIN \& BERUBE (2005), os processos oxidativos mais comuns associam as técnicas $\mathrm{O}_{3} / \mathrm{UV}, \mathrm{H}_{2} \mathrm{O}_{2} / \mathrm{UV}, \mathrm{H}_{2} \mathrm{O}_{2} / \mathrm{O}_{3}$ ou ainda $\mathrm{H}_{2} \mathrm{O}_{2} / \mathrm{O}_{3} / \mathrm{UV}$, embora outras combinações sejam possíveis.

\subsubsection{Efeito Oxidativo}

Em pesquisa recentemente publicada, CHIN \& BERUBE (2005) relatam a aplicação conjunta dos agentes ozônio e radiação UV na destruição de certos subprodutos da desinfecção. Para o desenvolvimento dos testes foram preparadas amostras em laboratório simulando condições de trihalometanos e ácidos 
haloacéticos.

No estudo os ensaios avaliaram três situações distintas para estabelecer o comportamento do parâmetro analítico carbono orgânico total: $\mathrm{O}_{3} / \mathrm{UV}$, apenas $\mathrm{O}_{3}$ e apenas UV. O resultado está indicado na Figura 3.9. A concentração de ozônio consumido foi estimada em $0.062 \mathrm{mg} / \mathrm{ml}$, enquanto a dose de radiação UV permaneceu em 1,61W.s/cm² [CHIN \& BERUBE (2005)].

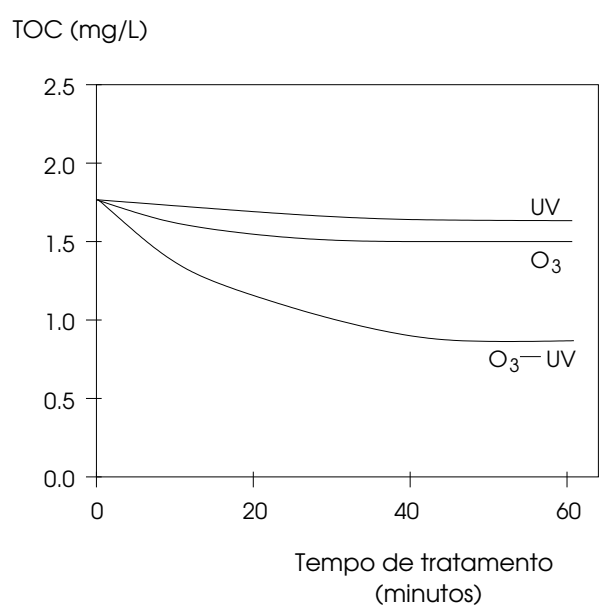

Figura 3.9: Desempenho dos métodos de oxidação $\mathrm{O}_{3} / \mathrm{UV}, \mathrm{O}_{3}$ e UV. Fonte adaptada: CHIN \& BERUBE (2005)

A tendência revelada nos três ensaios denota a capacidade acumulativa do potencial de oxidação no sistema combinado $\mathrm{O}_{3} / \mathrm{UV}$ nos primeiros 40 minutos de reação, enquanto nos métodos tratados individualmente $\left(\mathrm{O}_{3}\right.$ e UV) o efeito dos reagentes é mais significativo no momento de sua adição.

Experimentos realizados com efluente do processamento industrial do papel Kraft revelam redução substancial na concentração de matéria orgânica com a implantação de instalações combinadas $\mathrm{O}_{3} / \mathrm{UV}$. Outro aspecto observado, igualmente positivo, é a diminuição dos custos operacionais (em média 30\%) com a pré-ozonização do efluente, quando comparado ao método convencional [ALMEIDA et al. (2004)].

Resultados análogos se referem à otimização de sistemas de tratamento de efluente têxtil na remoção de cor e redução do consumo de oxigênio dissolvido no 
pós-tratamento com ozonização previa à degradação biológica. Essa tendência se deve, possivelmente, à conversão de compostos antes biologicamente refratários em substâncias biodegradáveis [ALMEIDA et al. (2004)].

Todavia, é importante ressaltar que o desempenho da metodologia apresentada está associado, em grande parte, às características físico-químicas do efluente, as quais estabelecem a demanda de ozônio, o grau de degradabilidade e o potencial de remoção da toxicidade.

\subsubsection{Efeito Germicida}

O conceito central da utilização de unidades combinadas para inativação de microrganismos patogênicos é induzir modificações bioquímicas, pela adição de agente químico ou físico, de modo a comprometer o desempenho de certas funções vitais. Desse modo, a desestruturação de grupos funcionais específicos intensifica os efeitos da desinfecção convencional, limitando a capacidade de resistência e recuperação do organismo lesado.

Segundo dados da Environmental Protection Agency, o número de microrganismos sobreviventes a duas etapas de desinfecção, em comparação a uma única etapa, sob condições semelhantes de dosagem e tempo de contato, é substancialmente inferior [EPA (1999)].

O uso de sistemas combinados tem sido reportado pela instituição americana no tratamento de águas de abastecimento com aplicação de substâncias como cloro, cloramina, dióxido de cloro, permanganato de potássio, ozônio e radiação ultravioleta, na inativação de espécies patogênicas [EPA (1999)].

Na Tabela 3.9 estão relacionados alguns resultados de experimentos realizados por KOIVUNEN \& HEINONEN-TANSKI (2005) com diferentes espécies de microrganismos e agentes de inativação. 
Tabela 3.9: Efeito das técnicas convencional e combinada na remoção de microrganismos.

\begin{tabular}{|c|c|c|}
\hline & Agente de Inativação & Sobreviventes ${ }^{a}$ \\
\hline \multirow[t]{3}{*}{ Cryptosporidium parvum $^{b}$} & ozônio & 1,6 \\
\hline & dióxido de cloro & 0,9 \\
\hline & ozônio/dióxido de cloro & 4,0 \\
\hline \multirow[t]{5}{*}{ 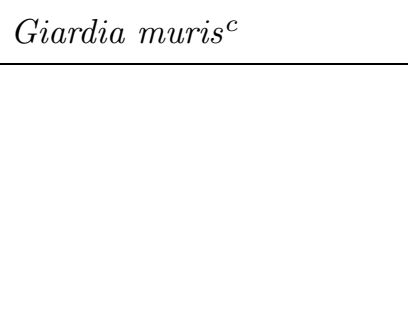 } & ozônio & 0,5 \\
\hline & cloro livre & 0,8 \\
\hline & monocloramina & 0,5 \\
\hline & ozônio/cloro livre & 2,3 \\
\hline & ozônio/monocloramina & 2,1 \\
\hline \multirow[t]{3}{*}{ Escherichia coli $^{d}$} & UV & 0,55 \\
\hline & ác.peracético & 0,04 \\
\hline & ác.peracético/UV & 1,02 \\
\hline \multirow[t]{5}{*}{ Enterococcus faecalise } & UV & 0,61 \\
\hline & $\mathrm{H}_{2} \mathrm{O}_{2}$ & 0,02 \\
\hline & ác.peracético & 0,11 \\
\hline & ác.peracético/UV & 1,05 \\
\hline & $\mathrm{H}_{2} \mathrm{O}_{2} / \mathrm{UV}$ & 0,43 \\
\hline \multirow[t]{5}{*}{ Colifago MS2 ${ }^{f}$} & UV & 0,79 \\
\hline & $\mathrm{H}_{2} \mathrm{O}_{2}$ & 0,07 \\
\hline & ác.peracético & 0,21 \\
\hline & ác.peracético/UV & 1,21 \\
\hline & $\mathrm{H}_{2} \mathrm{O}_{2} / \mathrm{UV}$ & 0,91 \\
\hline
\end{tabular}

Fonte adaptada: KOIVUNEN \& HEINONEN-TANSKI (2005), EPA (1999)

[a] Indicado como log da redução.

[b] Ozônio: 0,9mg/L; dióxido de cloro: 1,3mg/L.

[c] Ozônio: 0,1mg/L; cloro livre: 2,0mg/L; monocloramina: 2,0mg/L.

[d] UV: $10 \mathrm{~mW} . \mathrm{s} / \mathrm{cm}^{2}$; ác. peracético: $1,0 \mathrm{mg} / \mathrm{L}$.

[e] UV: $8 \mathrm{~mW} . \mathrm{s} / \mathrm{cm}^{2}$; ác. peracético: $0,5 \mathrm{mg} / \mathrm{L} ; \mathrm{H}_{2} \mathrm{O}_{2}: 3 \mathrm{mg} / \mathrm{L}$.

[f] UV: $22 \mathrm{~mW} . \mathrm{s} / \mathrm{cm}^{2}$; ác. peracético: $3,0 \mathrm{mg} / \mathrm{L} ; \mathrm{H}_{2} \mathrm{O}_{2}: 3 \mathrm{mg} / \mathrm{L}$. 
De acordo com a tabela, mesmo a presença de espécies resistentes ao tratamento convencional como Cryptosporidium parvum e vírus colifago pode ser reduzida a níveis consideravelmente inferiores quando conjugados dois agentes de inativação.

A fração sobrevivente $N / N_{0}$ neste caso pode ser determinada a partir dos valores obtidos para as mesmas técnicas analisadas isoladamente, como indica a equação (3.20) descrita por KOIVUNEN \& HEINONEN-TANSKI (2005).

$$
\left[\log \left(N / N_{0}\right)_{D}\right]=\left[\log \left(N / N_{0}\right)_{A B}\right]-\left[\log \left(N / N_{0}\right)_{A}\right]-\left[\log \left(N / N_{0}\right)_{B}\right]
$$

$\log \left(N / N_{0}\right)_{D}$ : Decréscimo na fração sobrevivente devido ao sistema combinado.

$\log \left(N / N_{0}\right)_{A B}$ : Fração sobrevivente aos agentes "A" e "B" conjuntamente.

$\log \left(N / N_{0}\right)_{A}$ : Fração sobrevivente ao agente "A".

$\log \left(N / N_{0}\right)_{B}:$ Fração sobrevivente ao agente "B".

Em estudo desenvolvido com cistos do parasita Cryptosporidium parvum, utilizando água de abastecimento, DRIEDGER et al. (2000) descrevem o efeito sinergístico de inativação decorrente da ação combinada da pré-ozonização seguida da adição de cloro livre.

Nesses experimentos, para se alcançar níveis de sobrevivência próximos de 0,01 foram necessárias dosagens relativas a 1.700mg.min/L e 370mg.min/L para os agentes cloro livre e $\mathrm{O}_{3}$ /cloro livre combinado, respectivamente. $\mathrm{O}$ uso conjunto de ozônio e cloro livre representa a redução de aproximadamente 4,5 vezes a dosagem necessária para se alcançar resultados semelhantes com aplicação de cloro livre apenas.

Embora a eficiência da radiação UV, na pré-desinfecção, esteja limitada à concentração e dimensão de sólidos suspensos, BLUME \& NEIS (2004) relatam sua utilização em efluente secundário após pré-tratamento com ultra-som, obtendo níveis bastante satisfatórios de inativação para coliformes fecais, Escherichia coli e Streptococcus faecalis. 
Segundo BLUME \& NEIS (2004), houve redução na variável $\log \left(\mathrm{N} / \mathrm{N}_{0}\right)$ de 1,7 para 3,9 nos ensaios com Escherichia coli e 2,1 para 3,4 com Streptococcus faecalis, ambos após aplicação de ultra-som por 10s seguida de radiação UV, com dosagem de 1500 W.s/L. Os resultados revelaram o efeito substancial do ultra-som na desagregação de partículas maiores que $50 \mu \mathrm{m}$, convertendo-as em componentes menores que possibilitaram a atuação dos raios UV.

A pesquisa divulga ainda, para as condições avaliadas, a diminuição dos custos operacionais, particularmente quanto ao consumo de energia elétrica, comparativamente aos mesmos índices obtidos sem a adição do ultra-som. 


\section{Capítulo 4}

\section{Metodologia}

\subsection{Fase Experimental: Planejamento}

A etapa de investigação experimental desta pesquisa está divida em duas partes principais: 1) ensaios de pré-desinfecção e 2) ensaios de desinfecção ambas submetidos a aplicação de gás ozônio e radiação ultravioleta. A descrição simplificada da totalidade de procedimentos concernentes à realização das etapas 1 e 2 está listada na Tabela 4.1.

Para a execução desses experimentos foi utilizado efluente de reator UASB, construído em escala real, situado na estação de tratamento de esgoto (ETE) do campus I USP/São Carlos, responsável pelo fornecimento de esgoto sanitário para alimentação da unidade piloto ali instalada sob regime contínuo de operação. Os ensaios desenvolvidos nesta fase compreendem a simulação da etapa de prédesinfecção seguida de tratamento biológico complementar.

A implantação da pré-desinfecção após o reator UASB se deve à necessidade de minimizar-se a concentração de sólidos em suspensão cuja presença diminui consideravelmente a eficiência de inativação de microrganismos tanto na técnica de ozonização quanto no uso de radiação UV [BILOTTA (2000)]. 
Tabela 4.1: Descrição sucinta da fase experimental.

Etapa 1: Pré-desinfecção

Projeto, montagem e instalação das unidades piloto

Operação das unidades piloto $\mathrm{O}_{3}$ e UV em regime contínuo

Ensaios com Ozônio

Determinação da capacidade de produção do gerador de ozônio

Coleta de amostras

Caracterização das amostras

Ensaios com Radiação UV

Determinação da capacidade de irradiação da fonte UV

Coleta de amostras

Caracterização das amostras

Manutenção periódica da fonte UV

Etapa 2: Desinfecção

Operação das unidades piloto $\mathrm{O}_{3}$ e UV em regime de batelada

Ensaios com ozônio

Determinação da capacidade de produção do gerador de ozônio

Elaboração da curva de calibração do equipamento

Determinação da concentração de ozônio residual e off-gas

Coleta de amostras

Caracterização das amostras

Ensaios com radiação UV

Determinação da capacidade de irradiação da fonte UV

Coleta de amostras

Caracterização das amostras 
Por sua vez, a etapa destinada à desinfecção efetiva foi realizada em regime de batelada utilizando-se o esgoto sanitário coletado após o tratamento biológico.

Em virtude da limitação de recursos latoratoriais no complexo onde está inserida a estação de tratamento de esgoto, esta segunda etapa foi produzido junto ao Laboratório de Tratamento de Resíduos Sólidos (LTR) no Departamento de Hidráulica e Saneamento do Campus I USP/São Carlos.

A seqüência de eventos que envolve as etapas 1 e 2 está esquematizada no diagrama em blocos apresentado na Figura 4.1.

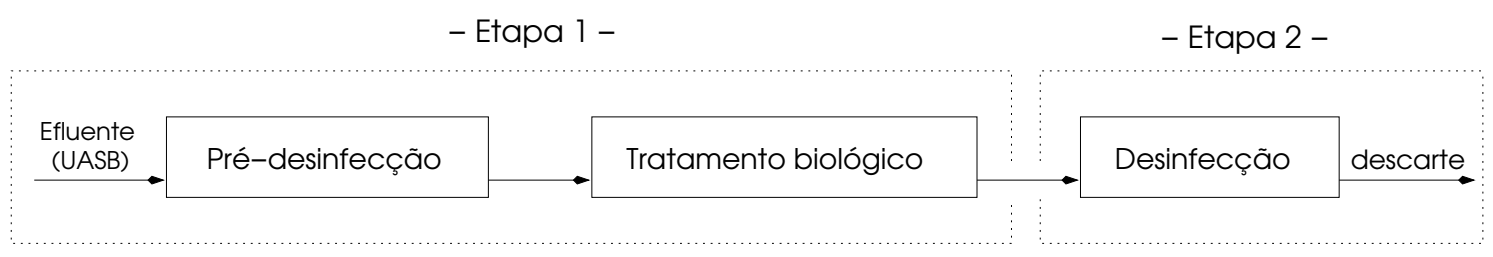

Figura 4.1: Diagrama em blocos das etapas 1 e 2.

O tratamento biológico indicado no diagrama foi realizado em leito de carvão ativado como meio suporte para o crescimento de biomassa, mantido sob permanente aeração.

A escolha desta técnica de pós-tratamento do efluente do reator UASB surge como resultado da integração entre este trabalho e a pesquisa de doutorado desenvolvida por Romeu Francisco Gadotti, sob a orientação do Prof. Dr. Luiz Antonio Daniel, visando, desse modo, o reaproveitamento de recursos já disponíveis [GADOTTI (2003)].

Para o estudo de caso foram simuladas duas condições: (1) controle e (2) experimentação, denominadas respectivamente unidade 1 e unidade 2. Na unidade 1 os procedimentos realizados reproduziram a condição convencional de tratamento, isto é, um único estágio, enquanto na unidade 2, o método alternativo com dois estágios, como descreve a Figura 4.2. 

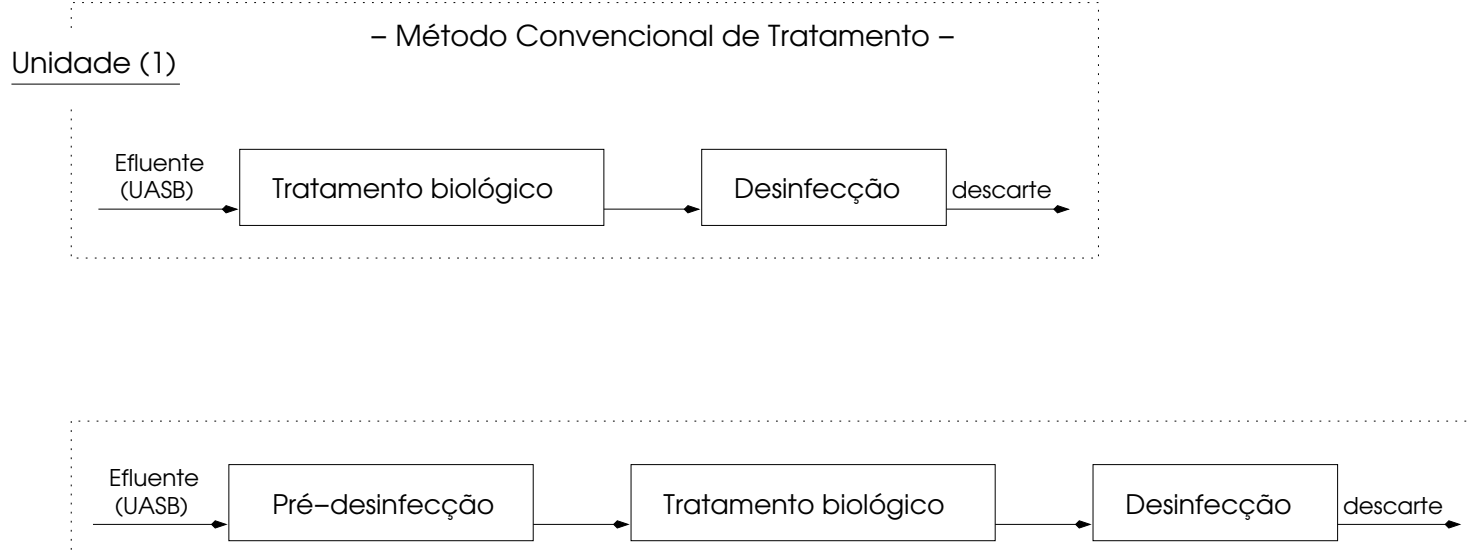

Unidade (2)

- Método Alternativo de Tratamento -

Figura 4.2: Representação das operações unitárias da fase experimental.

O efeito da implantação de duas etapas de desinfecção, sequencialmente dispostas, na atividade de certos indicadores patogênicos, foi avaliado em uma série de experimentos programados de acordo com o método de inativação adotado, como mostra a Figura 4.3.

Todos os ensaios indicados na programação experimental da Figura 4.3 foram processados em triplicata e estão identificados no texto como ensaio 1, ensaio 2 e ensaio 3.

\subsection{Descrição da Etapa 1}

A unidade experimental correspondente à primeira etapa opera em regime contínuo, alimentada pelo efluente secundário proveniente do tratamento anaeróbio no reator UASB.

A instalação piloto projetada para esta fase da pesquisa atende simultaneamente aos ensaios com ozônio e radiação ultravioleta, permitindo, com simples ajuste, o emprego de uma ou outra técnica de desinfecção em uma mesma unidade experimental. As operações envolvidas estão simplificadamente representadas no diagrama em blocos da Figura 4.4. 


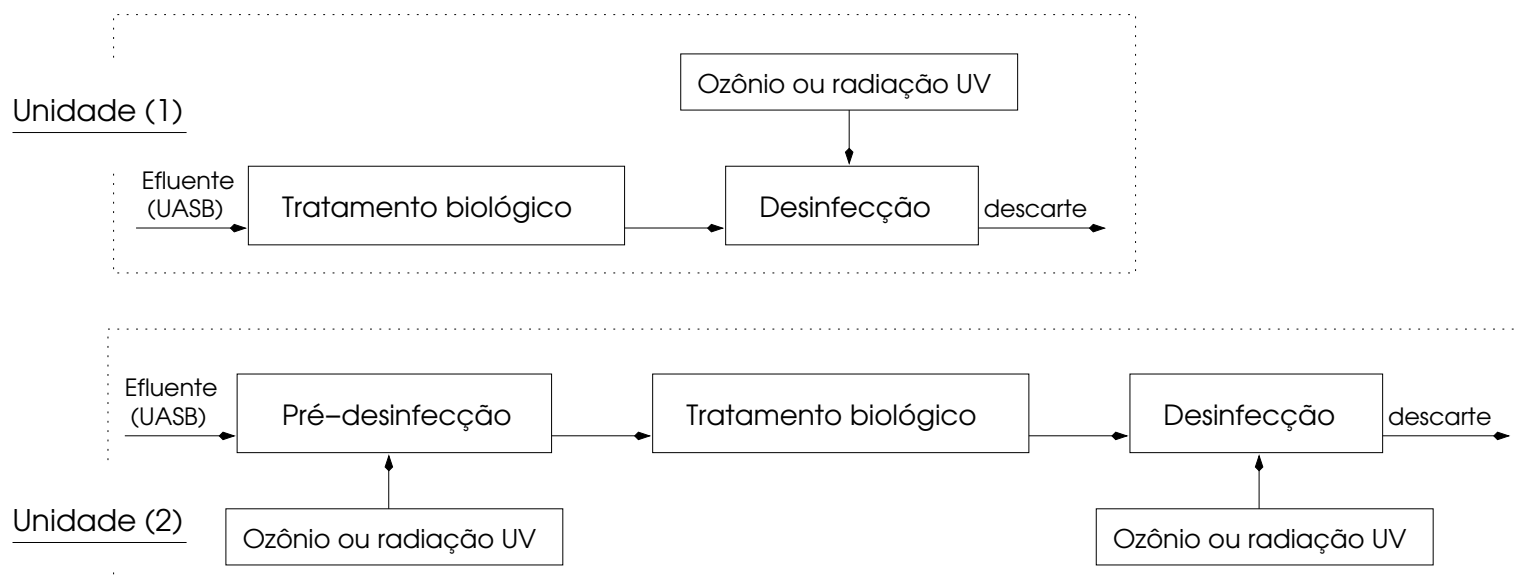

\begin{tabular}{ccc}
\multicolumn{3}{l}{ Programação Experimental } \\
\hline Unidade & (Etapa 1) & (Etapa 2) \\
\hline$(1)$ & --- & Ozônio \\
$(1)$ & --- & Radiação UV \\
$(2)$ & Ozônio & Ozônio \\
$(2)$ & Ozônio & Radiação UV \\
$(2)$ & Radiação UV & Ozônio \\
$(2)$ & Radiação UV & Radiação UV
\end{tabular}

Figura 4.3: Representação das operações unitárias e organograma experimental. 


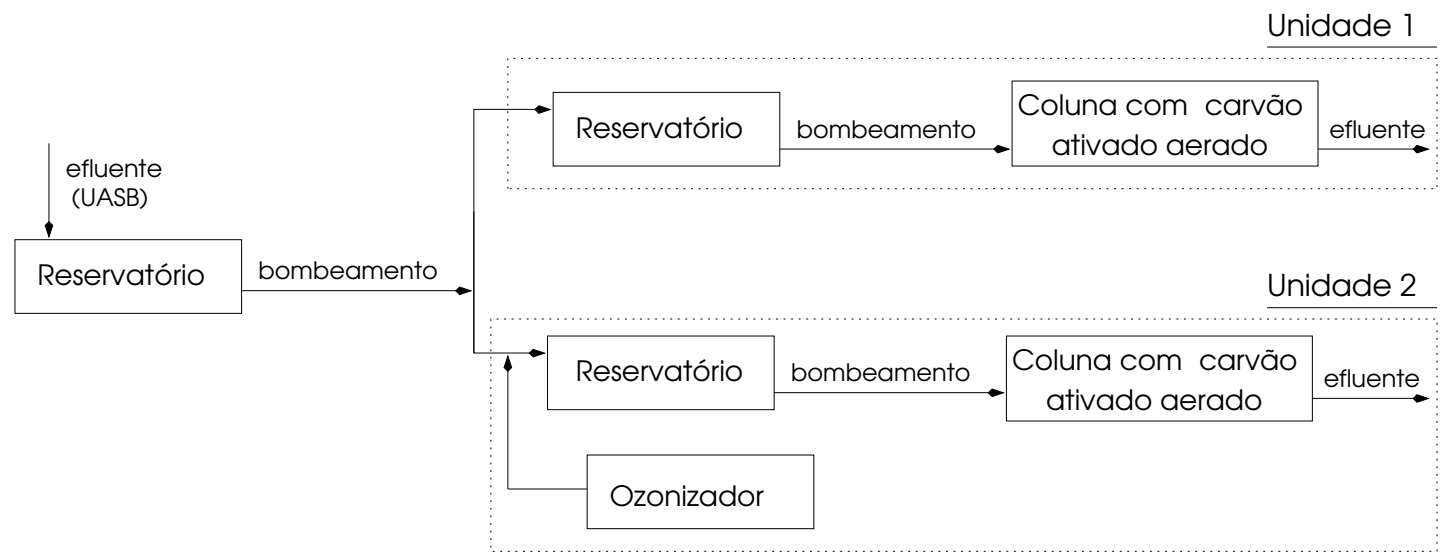

(a) Adição de ozônio gasoso.

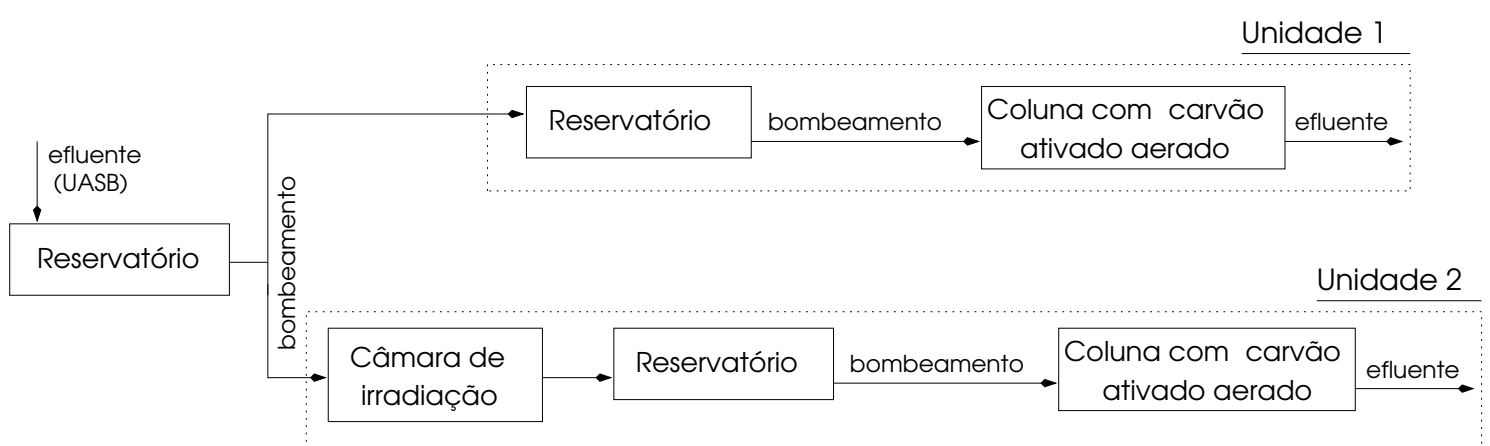

(b) Aplicação de radiação UV.

Figura 4.4: Etapas operacionais relativas a primeira fase experimental. 


\subsubsection{Ozonização}

A concentração de ozônio fornecido pelo gerador Prominent modelo Econoto, para o primeiro caso em exame, indicado na Figura 4.4(a), foi estimada a partir do método iodométrico descrito por APHA (1995).

Visto que o sistema de ozonização empregado na primeira etapa não permitia o controle da taxa de ozônio produzido ou mesmo o ajuste do tempo de contato na câmara de reação, o parâmetro $C . t^{1}$ permaneceu constante.

A representação da Figura 4.5 descreve os principais elementos constituintes da instalação piloto empregada nesta fase. No estudo da técnica de ozonização (unidade 2), a transferência gás-líquido ocorria por arraste da fase gasosa quando o efluente se deslocava do primeiro para o segundo reservatório, promovendo, assim, a mistura ozônio-efluente.

O efluente anaeróbio que abastecia o primeiro reservatório ${ }^{2}$, escoava por sifonamento a partir da saída do reator UASB, por gravidade. A distância vertical percorrida entre esses dois pontos foi fixada em aproximadamente $6 \mathrm{~m}$.

Em seguida, duas bombas de 3 e $7 \mathrm{~m}^{3} / \mathrm{h}$ respondiam pelo transporte desse efluente $^{3}$ e, então, para os reservatórios seguintes, destinados a prover as colunas de carvão ativado para o tratamento biológico. Os volumes internos dos reservatórios foram respectivamente 80L e 160L para as unidades 1 e 2 . O efluente armazenado era, então, bombeado para as colunas com vazão de 2,4L/h.

Com este procedimento foi possível garantir a permanente alimentação das colunas visto que o equipamento gerador de ozônio possui um dispositivo que suspende automaticamente suas funções, incluindo o bombeamento a partir do reservatório principal, por 16 horas diárias para resfriamento e regeneração de parte de seus componentes, reduzindo drasticamente a disponibilidade de efluente ozonizado.

\footnotetext{
${ }^{1}$ Produto da concentração de agente inativante e tempo de exposição.

${ }^{2}$ Com capacidade para armazenar até $500 \mathrm{~L}$.

${ }^{3}$ Por arraste da fase gasosa promovia a mistura gás-líquido na própria tubulação.
} 
(1) Reservatório principal

(2) Reservatório

(3) Bomba dosadora

(4) Coluna com carvão ativado

(5) Gerador de ozônio ou fonte emissora de radiação UV

(6) Ar comprimido

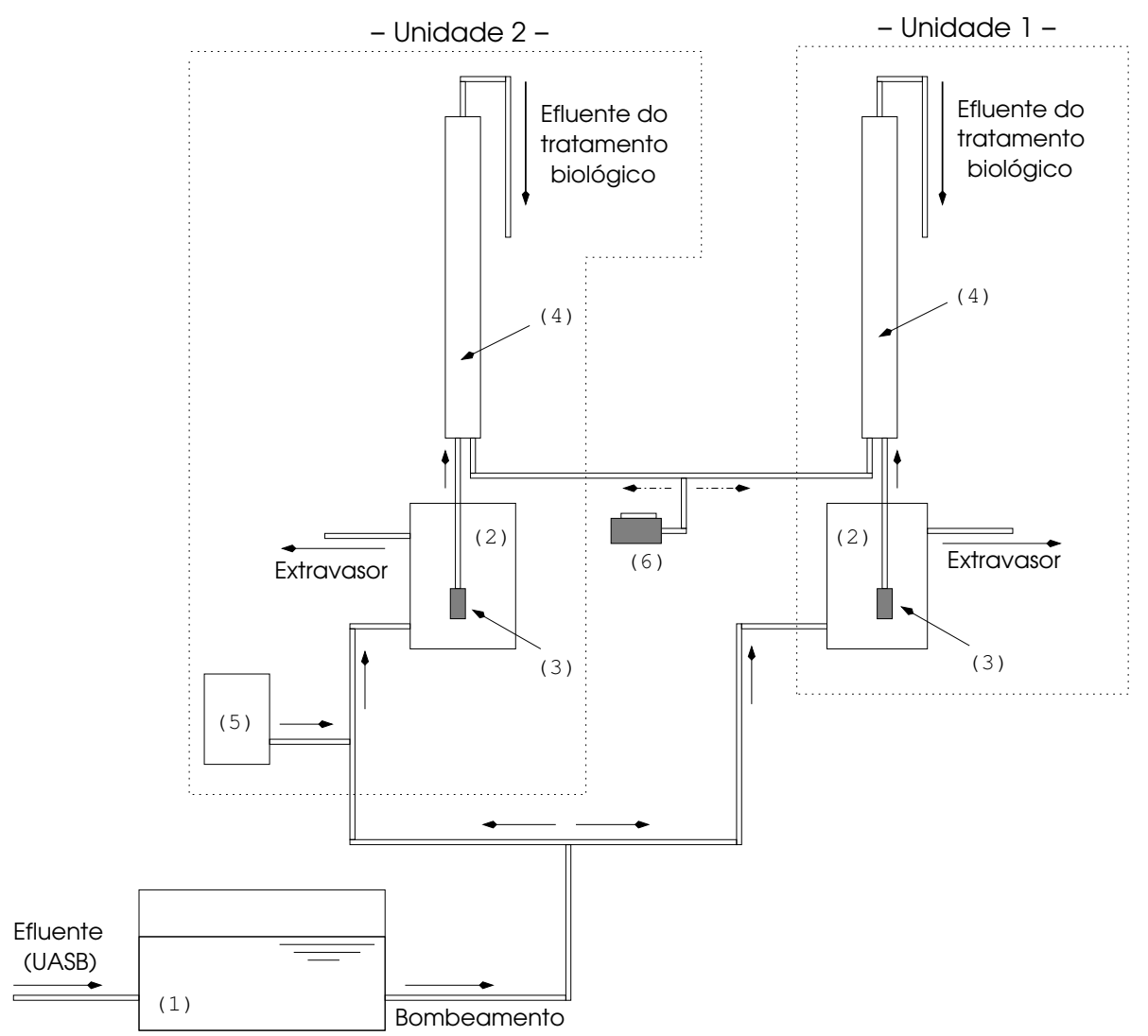

Figura 4.5: Esquema simplificado da instalação piloto para a etapa 1. 
Na tubulação, previamente à entrada do esgoto no reservatório principal, foram instalados dois registros de esfera, os quais permitiam regular a saída do esgoto em direção à câmara de ozonização (ensaios com ozônio) ou à câmara de irradiação (ensaios com ultravioleta), respectivamente. Desse modo, dependendo da técnica aplicada, o efluente era transferido para o correspondente reservatório e em seguida para a coluna contendo carvão ativado simplesmente deslocando a bomba dosadora de um tanque para o outro.

\subsubsection{Radiação UV}

No segundo estudo de caso observado na Figura 4.4(b), uma única lâmpada ultraviolta, modelo Phillips G15-T8, com potência nominal 15W e baixa pressão de vapor de mercúrio, foi responsável pela emissão de energia luminosa em 254nm para promover as reações fotoquímicas nos ensaios de desinfecção. A intensidade média de radiação UV transferida pela lâmpada para a lâmina líquida foi estimada pelo método actinométrico.

Os ensaios com radiação ultravioleta foram realizados em regime contínuo de alimentação no reator fotoquímico do tipo anular, representado na Figura 4.6. Como pode ser observado, o efluente percorria a câmara de contato longitudinalmente ao posicionamento da lâmpada nela fixada, possibilidade durante este contato a efetiva inativação de microrganismos ali presentes.

Após a saída do reator, o efluente irradiado era conduzido para o próximo reservatório e, em seguida, bombeado para a coluna com carvão ativado destinada ao tratamento biológico (Figura 4.5).

O período de detenção do efluente no interior do reator fotoquímico foi definido com base na vazão de entrada do efluente e o volume livre disponível na unidade piloto. 
Corte Longitudinal

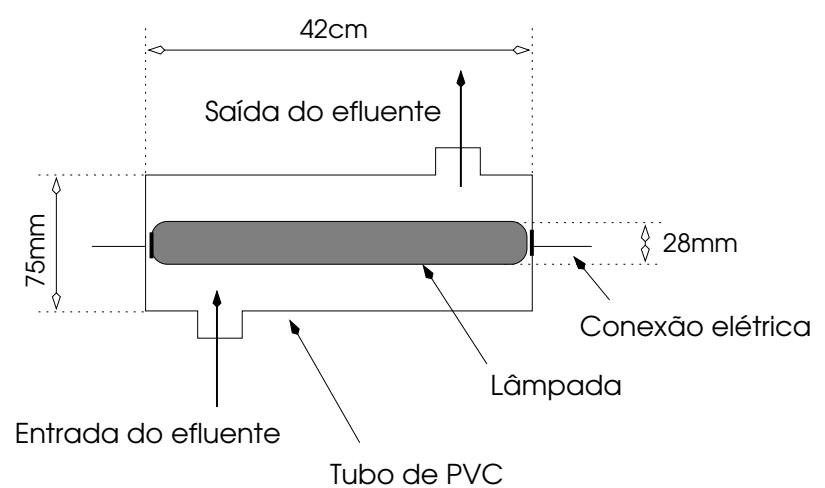

Vista Frontal

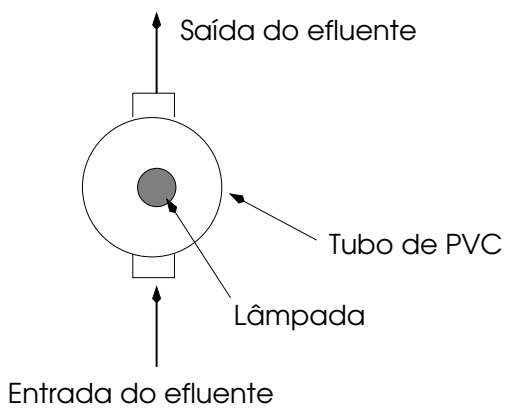

Figura 4.6: Representação esquemática do reator fotoquímico da etapa 1.

\subsubsection{Unidade de Tratamento Biológico}

Além dos procedimentos descritos anteriormente, nesta primeira etapa da fase experimental o efluente proveniente do reator UASB era também submetido ao filtro biológico. A unidade experimental implantada para a realização destes ensaios está indicada na Figura 4.7.

A coluna, construída em PVC, contem carvão ativado granular, utilizado nos ensaios apenas como meio suporte para o crescimento da biomassa ${ }^{4}$.

O sistema, sob regime contínuo, era mantido sob aeração permanente com ar pressurizado pelo compressor Schulz modelo MS-3,7/6 ajustado para fornecer 4bar na entrada das colunas representadas na Figura 4.5.

O tempo de detenção do efluente junto à biomassa foi determinado a partir da vazão de entrada do esgoto na coluna e do volume total por ele ocupado (somatória dos volumes de carvão ativado e do próprio efluente).

\footnotetext{
${ }^{4}$ Metodologia detalhada apresentada por GADOTTI (2003).
} 


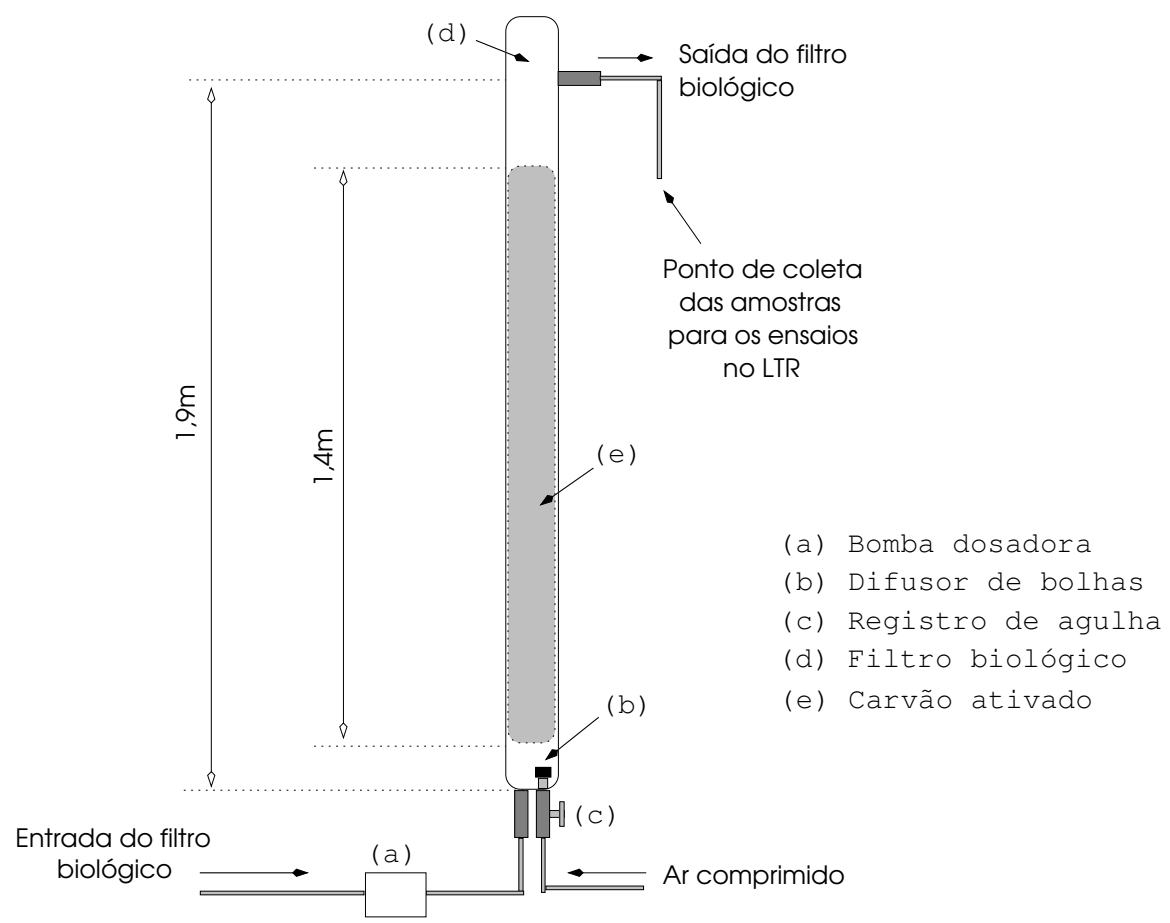

Figura 4.7: Unidade experimental para o tratamento biológico.

\subsubsection{Parâmetros Experimentais: Etapa 1}

Na Tabela 4.2 estão relacionados os parâmetros operacionais definidos para esta etapa da pesquisa. Alguns dados apresentados foram obtidos experimentalmente enquanto outros estimados através de cáculos matemáticos.

\section{Pontos de Amostragem}

Para se estimar o comportamento do esgoto ao longo da primeira etapa de desinfecção foram realizadas coletas em diferentes pontos para posterior caracterização físico-químico e microbiológico. Os pontos escolhidos para a amostragem dos ensaios descritos foram:

(P1): efluente bruto (anaeróbio);

(P2-uv): efluente bruto após irradiação com UV;

(P3-uv): efluente após irradiação com UV seguido de tratamento biológico;

$\left(\mathrm{P} 2-\mathrm{O}_{3}\right)$ : efluente bruto ozonizado;

$\left(\mathrm{P} 3-\mathrm{O}_{3}\right)$ : efluente ozonizado seguido de tratamento biológico;

(P4): efluente bruto seguido de tratamento biológico. 
Tabela 4.2: Dados operacionais para a etapa 1.

$\begin{array}{lc}\text { Etapa } 1 \text { - Pré-desinfeç̧̃̃o } & \\ \text { Ozonização } & 1,0 \mathrm{mg} / \mathrm{L} \\ \text { Dose teórica } & 4,6 \mathrm{~h} \\ \text { Tempo de detenção }{ }^{a} & 9 \mathrm{~L} / \mathrm{min} \\ \text { Vazão de } \mathrm{O}_{3} & 6,8 \mathrm{~m}^{3} / \mathrm{h} \\ \text { Vazão do efluente } & \\ & \\ \text { Radiação UV } & 2,3 \mathrm{~cm} \\ \text { Espessura da lâmina líquida } & 5,1 \mathrm{~mW} / \mathrm{cm}^{2} \\ \text { Intensidade de radiação } I_{0} & 1 \\ \text { Número de lâmpadas no reator } & 10 \mathrm{~s} \\ \text { Tempo de detenção } & \\ \text { Tempo de detenção } & \\ \text { Vazão do efluente } & 4,6 \mathrm{~h} \\ \text { Volume do reator } & 6 \mathrm{~L} / \mathrm{min} \\ \end{array}$

[a] Tempo de detenção nas colunas no tratamento biológico.

[b] Tempo de detenção no reator fotoquímico.

\subsection{Descrição da Etapa 2}

Para o desenvolvimento da segunda fase dos experimentos, com as unidades piloto $\mathrm{O}_{3}$ e UV operando em regime de batelada, foram utilizados 20L de amostra coletada semanalmente na saída da coluna no tratamento biológico da etapa anterior.

\subsubsection{Ozonização}

A instalação piloto, onde foram promovidas as reações de desinfecção ${ }^{5}$, era composta por uma série de procedimentos preliminares dispostos previamente a entrada do gás $\mathrm{O}_{2}$ no equipamento gerador de ozônio Qualid'or com capacidade nominal para $7 \mathrm{~g}$ de $\mathrm{O}_{3} / \mathrm{h}$.

\footnotetext{
${ }^{5}$ Os experimentos executados nesta etapa seguem a programação descrita anteriormente na Figura 4.3.
} 
As várias operações unitárias que compõem a instalação piloto $\mathrm{O}_{3}$ utilizada nos ensaios de desinfecção na etapa 2 estão indicadas na Figura 4.8.

(1) Cilindro de oxigênio

(2) Rotâmetro

(3) Câmara de refrigeração

(4) Gerador de ozônio

(5) Câmara de ozonização

(6) Frasco lavador

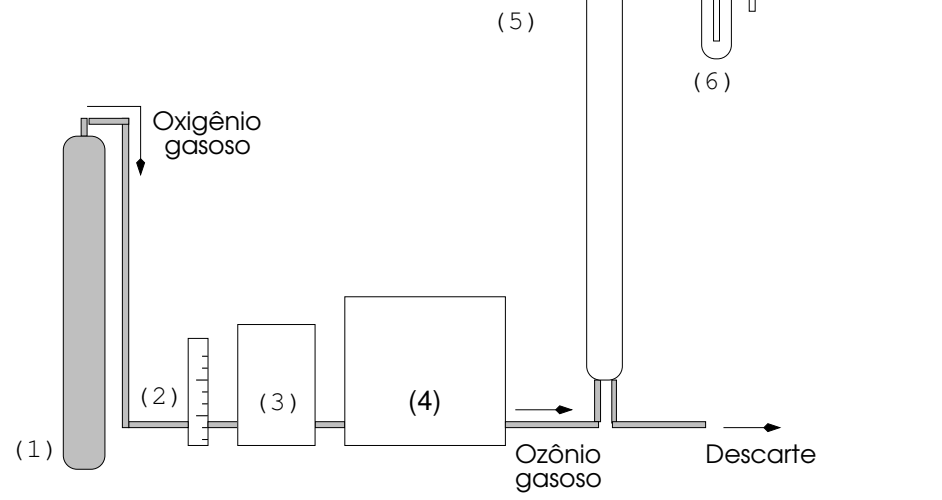

Figura 4.8: Representação simplificada da unidade piloto $\mathrm{O}_{3}$ da etapa 2.

O cilindro de oxigênio pressurizado era responsável pelo fornecimento de matéria-prima para produção de ozônio gasoso com rendimento máximo, visto que a fração de oxigênio presente no ar atmosférico seria consideravelmente inferior. A passagem de $\mathrm{O}_{2}$ pelo rotâmetro permitia o controle e ajuste de sua vazão na entrada do gerador de ozônio. O rotâmetro $O M E L$, utilizado nesses ensaios, possuia uma coluna de vidro graduada e uma esfera metálica que flutuava na escala de 0 a 400L/h indicando a correspondente vazão do fluxo de ar introduzido.

Em seguida, o oxigênio gasoso atravessava a câmara de refrigeração, modelo Belliere, percorrendo uma serpentina imersa em água mantida a baixa temperatura (em torno de $4^{\circ} \mathrm{C}$ ), uma vez que temperaturas inferiores diminuem a taxa de decomposição do ozônio formado. Finalmente, o oxigênio processado era transferido para o gerador iniciando-se, assim, sua conversão em ozônio gasoso. 
É importante destacar que antes dos primeiros ensaios o ozonizador era mantido em funcionamento por cerca de 15 minutos para seu aquecimento e estabilização. Deve-se ressaltar ainda o cuidado na escolha do ambiente para instalação do equipamento pois, em determinadas concentrações, o acúmulo de gás ozônio é extremamente tóxico [WEF (1996)].

A câmara de ozonização, construída em acrílico com 100mm de diâmetro interno, possuia difusor localizado em sua extremidade inferior para dispersão da fase gasosa introduzida. Os principais componentes da câmara de contato estão representados na Figura 4.9.

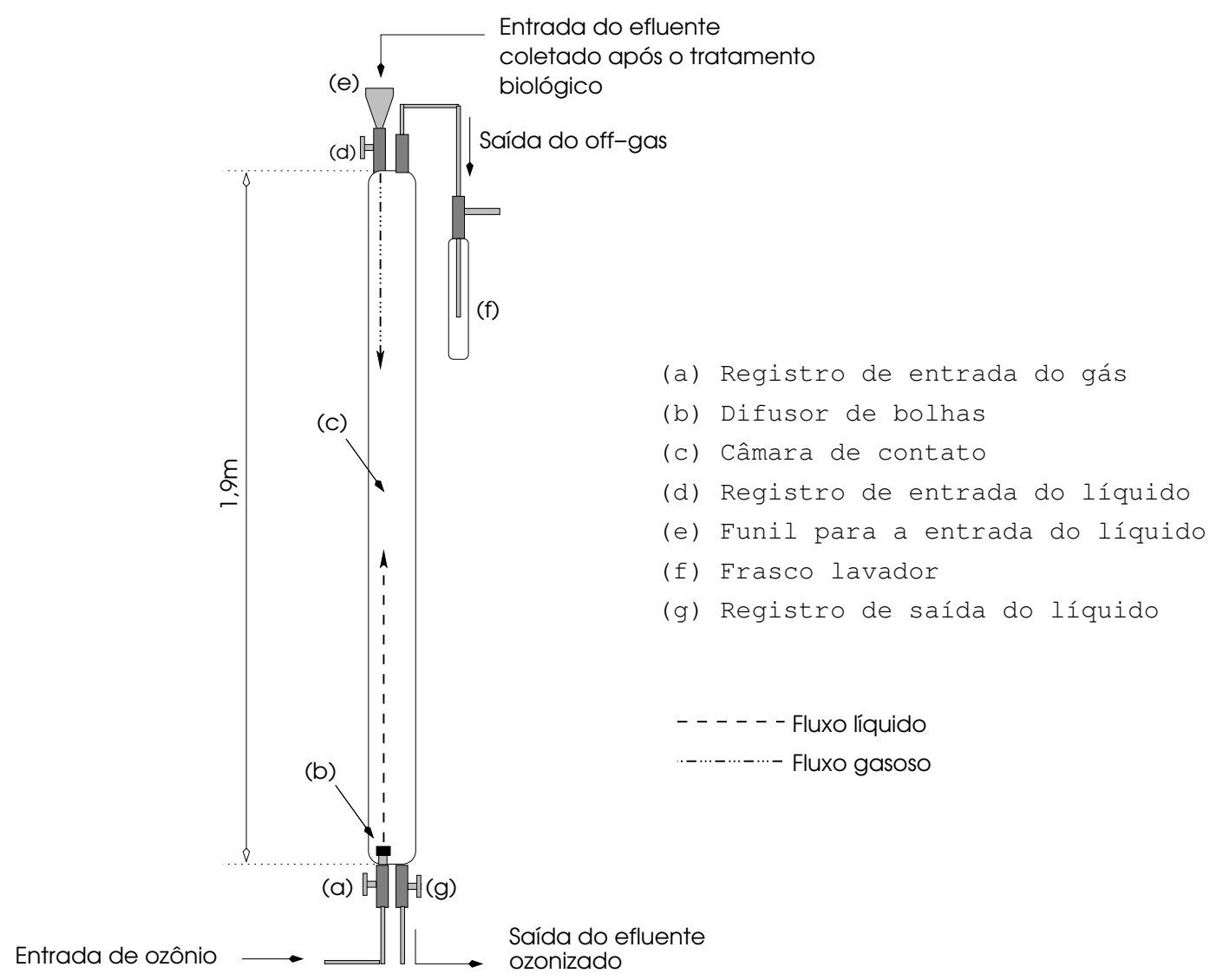

Figura 4.9: Câmara de ozonização para a etapa 2.

Preenchida a coluna com o efluente coletado na saída do tratamento biológico da etapa anterior, o registro de esfera (d) era fechado, o gerador de ozônio ligado e o registro de agulha (a) aberto, iniciando, assim, a ozonização. O gás ozônio 
não consumido na coluna, ou off-gas, era retido na solução iodeto de potássio ${ }^{6}$ no frasco lavador (f). Concluído o tempo de contato, o ozonizador era desligado e os registros de esfera (d) e (g) abertos para escoamento do efluente ozonizado.

\subsubsection{Ensaios com Radiação UV}

Os ensaios com radiação ultravioleta foram realizados na instalação piloto representada pela Figura 4.10. Durante os experimentos, o efluente era mantido sob constante agitação magnética para impedir a sedimentação de sólidos suspensos.

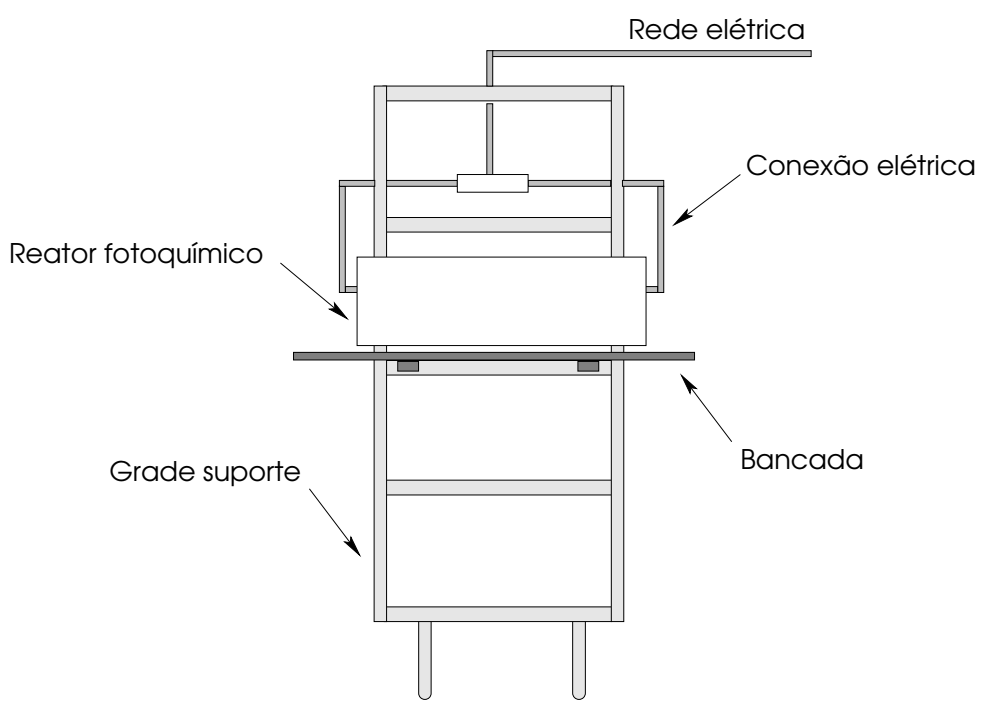

Figura 4.10: Unidade experimenal para os ensaios com radiação UV na etapa 2.

Previamente ao início dos ensaios, com o reator contendo água limpa, o sistema de lâmpadas era acionado e mantido em operação por cerca de 15 minutos para estabilização da temperatura. O acionamento das lâmpadas ocorria simultaneamente por meio de um único interruptor que unia suas extremidades à rede elétrica.

A câmara de reação em formato paralelepípedo-reto-retangular foi construída em aço inoxidável com tampo removível produzido em alumínio para garantir máxima refletividade em 254nm (próxima de 80\%).

\footnotetext{
${ }^{6}$ Metodologia para determinação da concentração de ozônio está descrita em APHA (1995).
} 
No tampo, ou, cúpula refletora, foram fixadas 6 lâmpadas Phillips G15-T8, com potência nominal $15 \mathrm{~W}$, de baixa pressão de vapor de mercúrio e longa duração, dispostas paralelamente e distantes $4 \mathrm{~cm}$ entre si, posicionadas alguns centímetros acima da lâmina líquida, como mostra a Figura 4.11(b).

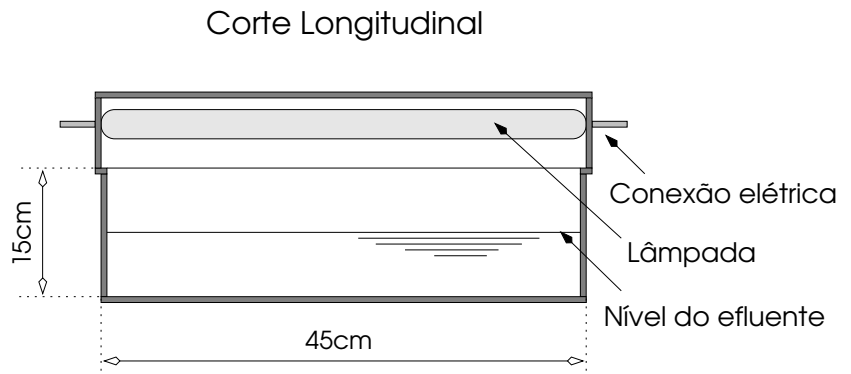

Vista Frontal

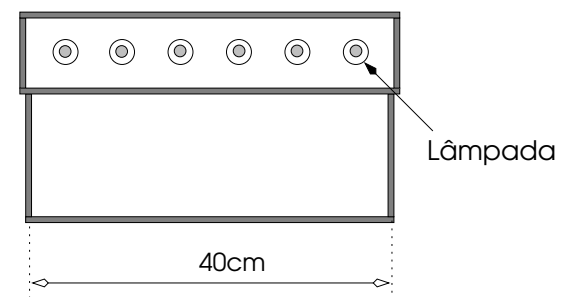

(a) Reator fotoquímico.

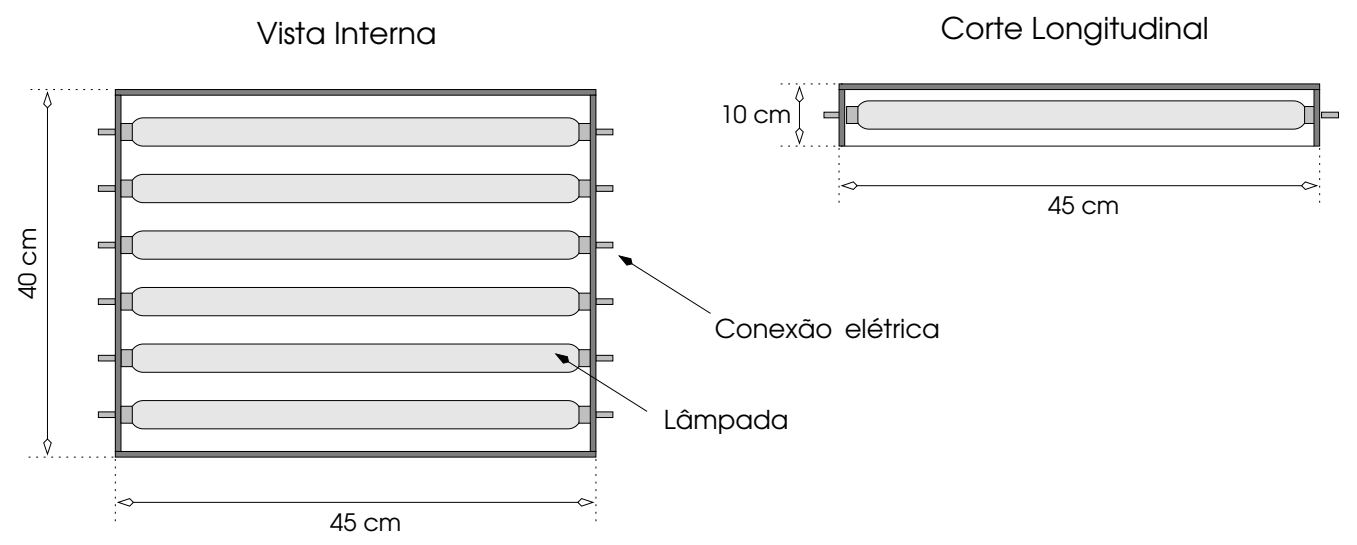

(b) Cúpula refletora.

Figura 4.11: Representação simplificada da câmara de irradiação para a etapa 2. 


\subsubsection{Parâmetros Experimentais: Etapa 2}

As condições operacionais estabelecidas para a segunda etapa dos experimentos estão relacionadas na Tabela 4.3.

Tabela 4.3: Dados operacionais para a segunda etapa da pesquisa.

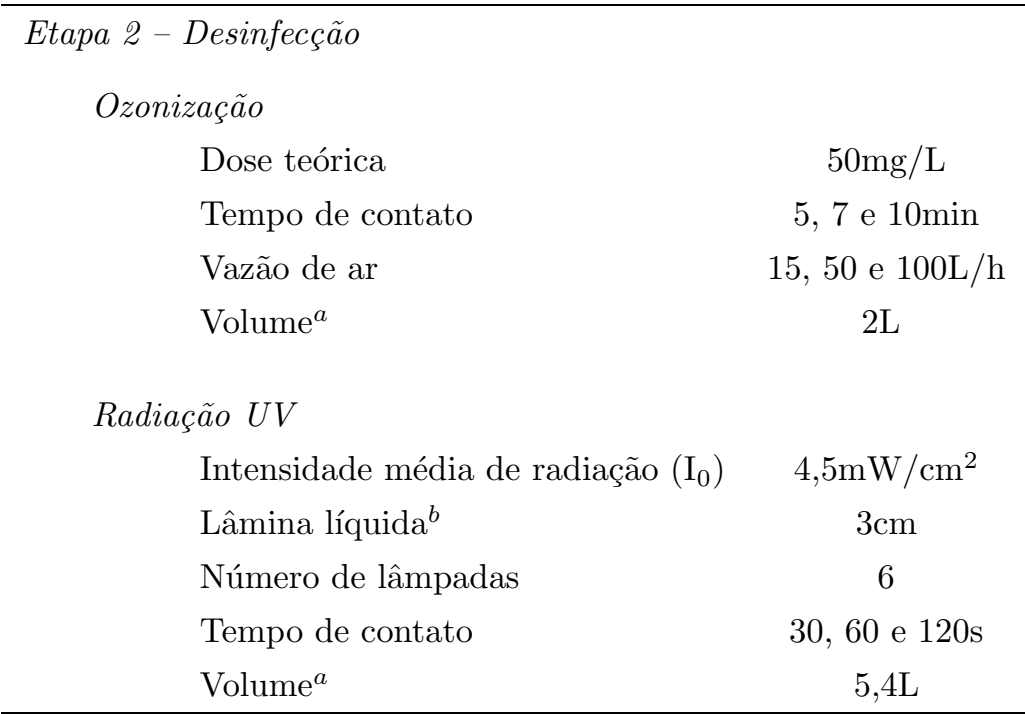

[a] Volume de efluente para cada um dos reatores utilizados.

[b] Altura da camada líquida na câmara de contato.

\section{Pontos de Amostragem}

Para a caracterização físico-química e microbiológica do efluente submetido à etapa 2 foram coletadas amostras antes e após os ensaios de desinfecção com ozônio e radiação UV na etapa 2, totalizando 8 pontos para os três tempos de contato investigados em cada ensaio.

\subsection{Procedimentos Auxiliares}

Além da metodologia descrita para os ensaios de desinfecção, foi necessária a utilização de procedimentos auxiliares para se estimar importantes requisitos, 
sendo eles: concentração de ozônio na fase gasosa ${ }^{7}$ (método iodométrico), concentração de ozônio residual na fase líquida (método indigo-blue), concentração de ozônio no off-gas (método iodométrico) e intensidade média de radiação UV emitida pelos reatores fotoquímicos nas etapas 1 e 2 (método actinométrico e radiometria, respectivamente).

\subsubsection{Calibração do Equipamento Gerador de $\mathrm{O}_{3}$}

O método iodométrico ${ }^{8}$ foi escolhido como procedimento para se estabelecer a capacidade de produção de $\mathrm{O}_{3}$ dos equipamentos instalados nas etapas 1 e 2 , bem como para determinar a fração off-gas retida no frasco lavador.

\section{Método Iodométrico}

Nos ensaios destinados à calibração do gerador de ozônio foram utilizadas volumes de 1,5L de solução iodeto de potássio ${ }^{9}$ submetidas à ozonização por 5 minutos, para diversas vazões de ar na entrada do equipamento. Concluído o tempo de contato, $100 \mathrm{~mL}$ da solução ozonizada era coletada e imediatamente analisada por titulometria com solução tiossulfato de sódio 0,025N [APHA (1995)].

Para cada vazão ajustada foi determinada a correspondente produção de $\mathrm{O}_{3}$ de acordo com a equação (4.1).

$$
P=\frac{N \cdot 1440 \cdot\left(V_{t}-V_{b}\right) \cdot V_{c}}{V \cdot t}
$$

$P$ : Produção de $\mathrm{O}_{3}\left(\right.$ g de $\left.\mathrm{O}_{3} / \mathrm{h}\right)$;

$N$ : Normalidade da solução tiossulfato de sódio $(\mathrm{N})$;

$t$ : Tempo de contato (min);

$V$ : Volume coletado da amostra ozonizada $(\mathrm{mL})$;

$V_{c}$ : Volume da solução iodeto de potássio na câmara de contato (L);

$V_{t}$ : Volume da solução tiossulfato de sódio consumido no ensaio $(\mathrm{mL})$;

${ }^{7}$ Para determinação da capacidade real de geração de $\mathrm{O}_{3}$ do aparelho.

${ }^{8}$ Descrito detalhadamente em APHA (1995).

${ }^{9}$ Metodologia descrita em APHA (1995). 
$V_{b}$ : Volume da solução tiossulfato de sódio consumido no ensaio para o branco $(\mathrm{mL})$;

1440 : Fator de conversão de unidades.

O volume $V_{b}$ se refere à titulação de substâncias oxidantes presentes na solução iodeto de potássio anterioremente à ozonização. Para determinar o valor do branco uma amostra de 100mL da solução iodeto de potássio não ozonizada foi titulada com tiossulfato de sódio $\left(V_{t}\right)$ e iodo $0,005 \mathrm{~N}\left(V_{i}\right)$. A somatória dos volumes $V_{t}$ e $V_{i}$ fornece o valor de $V_{b}$. A partir desses dados foi estabelecida graficamente a relação entre as variáveis produção de ozônio e vazão de ar ajustada.

Na prática, entretanto, o ajuste da vazão somente foi possível nos ensaios realizados na etapa 2 visto que o gerador de ozônio instalado na etapa 1 não possui este recurso. Sendo assim, o método iodométrico permitiu, neste caso, apenas a determinação da concentração de $\mathrm{O}_{3}$ real fornecida pelo aparelho para a condição particular imposta pelo fabricante.

Em seguida, com base na equação da curva obtida, foram calculadas as vazões necessárias para se alcançar a dosagem e tempos de contato definidos para esta pesquisa. A relação entre produção e dosagem é descrita pela expressão (4.2).

$$
P=\frac{D \cdot V_{e} \cdot 6 \cdot 10^{-2}}{t_{e}}
$$

$D$ : Dose de $\mathrm{O}_{3}(\mathrm{mg} / \mathrm{L})$;

$V_{e}:$ Volume de efluente (L);

$t_{e}:$ Tempo de contato (min);

$6.10^{-2}$ : Fator de conversão de unidades.

O procedimento descrito foi também aplicado na determinação da concentração de off-gas, apenas corrigindo o volume $V_{c}$ da equação (4.1) para $500 \mathrm{~mL}$.

\section{Método Indigo-blue}

A concentração de ozônio residual nas várias amostras analisadas foi estimada pelo método indigo-blue com o kit Acuvac do fabricante Merck. Ao contato com o agente oxidante, o reagente específico presente no kit muda de coloração tornando 
a solução azulada. Como resultado, a leitura colorimétrica da solução obtida, no equipamento $D R 2000$, fornece a fração residual expressa em mg de $\mathrm{O}_{3} / \mathrm{L}$.

\subsubsection{Intensidade Média de Radiação UV}

Dada a não uniformidade de distribuição da energia UV na fase líquida foi conveniente determinar ao menos sua intensidade média emitida em $254 \mathrm{~nm}$. O valor pode ser estimado por diferentes métodos, divididos em dois grupos principais: (1) princípio físico, (2) princípio químico.

Para os ensaios com radiação UV nas etapas 1 e 2 foram adotadas as técnicas de actinometria e radiometria, respectivamente.

\section{Método Actinométrico}

O ensaio actinométrico se inicia com o acionamento da fonte UV por 15 minutos, com o interior do reator fotoquímico contendo água limpa, para aquecimento e estabilização da lâmpada. Em seguida, descartada a água, o reator era preenchido com solução ferrioxalato de potássio e mantido ligado por 5 minutos.

Concluído o tempo de contato eram coletadas amostras da solução antes e após a irradiação com ultravioleta para leitura em espectrofotômetro da absorbância em 510nm. Substituindo esses valores na equação de calibração do equipamento (expressão 4.3) obtem-se a fração de íons $\mathrm{Fe}^{2+}$ nas várias amostras analisadas [HATCHARD \& PARKER (1956)].

$$
F e^{2+}=\frac{C_{F e^{2+}} \cdot V_{s}}{V_{a}}
$$

$\mathrm{Fe}^{2+}$ : Concentração de $\mathrm{Fe}^{2+}(\mathrm{mg} / \mathrm{L})$;

$C_{\mathrm{Fe}^{2+}}$ : Concentração de $\mathrm{Fe}^{2+}$ lida no espectrofotômetro $(\mathrm{mg} / \mathrm{L})$;

$V_{s}$ : Volume da solução irradiada $(100 \mathrm{~mL})$;

$V_{a}$ : Amostra da solução irradiada $(2 \mathrm{~mL})$;

Por fim, aplicando o resultado desses cálculos nas equações (3.17) e (3.18) foi possível estimar a intensidade de radiação ultravioleta $\left(I_{0}\right)$ emitida pelo sistema 
fotoquímico na unidade piloto da etapa 1.

A curva de calibração armazenada no espectrofotômetro é estabelecida a partir da correlação entre volumes definidos de solução sulfato ferroso $4.10^{-4} \mathrm{M}$ e sua correspondente absorbância lida no equipamento.

\section{Método Radiométrico}

A intensidade de radiação gerada em $254 \mathrm{~nm}$ no reator fotoquímico da etapa 2 foi estimada pela técnica de radiometria. O equipamento modelo $U V X R a$ diometer Part 97-0015-02 contem um sensor que permite quantificar a energia luminosa emitida pela lâmpada no ponto desejado.

Para a câmara de contato utilizada nesta fase da pesquisa, foram escolhidos os pontos ilustrados na Figura 4.12.

Cada ponto era lido isoladamente, posicionando o sensor precisamente no local indicado na figura. Em seguida, a câmara era fechada e o sistema de lâmpadas acionado, permanecendo em funcionamento por 5 minutos. Ao final deste período o valor indicado no aparelho era anotado e as lâmpadas desligadas. O mesmo procedimento foi repetido para os demais pontos representados na figura.

Reator fotoquímico (vista interna)

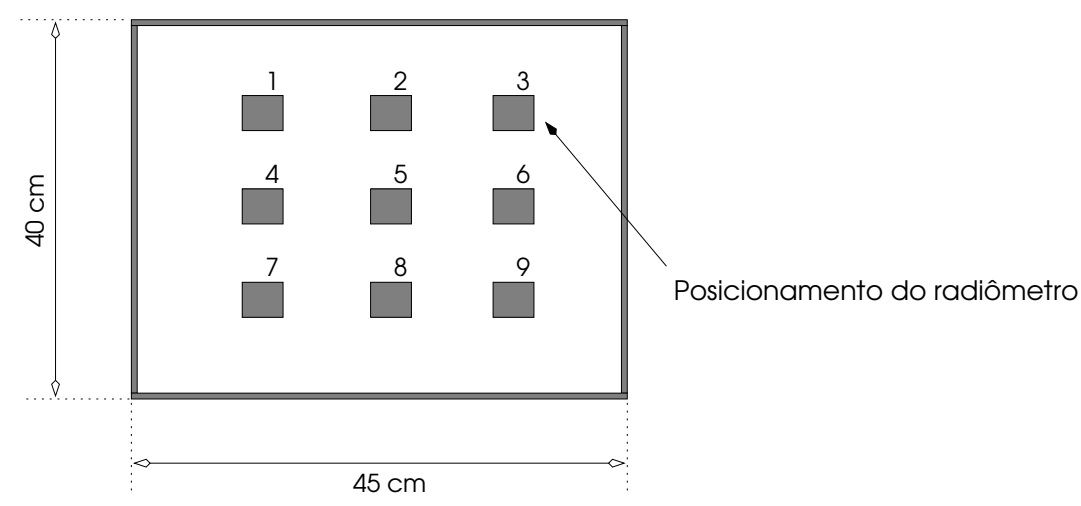

Figura 4.12: Leitura da intensidade de radiação pontual em 254nm. 


\subsection{Modelo de Inativação}

Nesta pesquisa, como ferramenta para a análise da taxa de inativação em relação ao tempo de exposição, para o agente químico $\left(\mathrm{O}_{3}\right)$ e físico (UV), foi adotado o modelo matemático de Chick. A expressão cinética de primeira ordem é descrita como sendo:

$$
\frac{N}{N_{0}}=e^{-k . t}
$$

$N$ : Concentração de microrganismos após a ação do agente oxidante (NMP/100mL);

$N_{0}$ : Concentração inicial de microrganismos (NMP/100mL);

$k$ : Constante de reação $\left(\min ^{-1}\right)$;

$t$ : Tempo de contato (min).

A relação $N / N_{0}$ representa a fração de microrganismos sobreviventes à desinfecção após transcorrido o intervalo de tempo $t$.

\subsection{Análises e Exames}

Além dos aspectos abordados, os ensaios de desinfecção foram seguidos de análises físico-químicas e exames microbiológicos para caracterização das amostras coletadas durante a realização da fase experimental.

A relação dos parâmetros avaliados inclui: demanda química de oxigênio (DQO), pH e alcalinidade, sólidos suspensos totais (SST) e voláteis (SSV), concentração de ozônio residual e off-gas, absorbância em 254nm, número de coliformes totais, Escherichia coli, Clostridium perfringens e colifagos. 
Os métodos analíticos utilizados estão descritos na Tabela 4.4. Os procedimentos adotados seguem os padrões relatados em APHA (1995).

Tabela 4.4: Métodos analíticos para caracterização das várias amostras.

\begin{tabular}{l}
\hline Procedimentos \\
DQO - Hach DR2000 \\
pH, alcalinidade — Titulação potenciométrica \\
Série de sólidos - Membranas filtrantes \\
Absorbância — Espectrofotômetro em 254nm \\
Colifago $^{a}$ - Contagem de placas \\
Escherichia coli e Col. totais ${ }^{b}$ - Membranas filtrantes \\
Clostridium perfringens ${ }^{c}$ - Tubos múltiplos
\end{tabular}
[a] Método CETESB LS.225-1990.
[b] Meio de cultura Chromocult.
[c] Método CETESB L5.213. 


\section{Capítulo 5}

\section{Resultados e Discussões}

Neste capítulo são analisados os dados experimentais coletados ao longo da pesquisa, organizados e distribuídos em quatro seções principais, visando facilitar sua abordagem e a compreensão dos eventos mencionados. A descrição sucinta de cada uma das partes está indicada na Tabela 5.1.

Tabela 5.1: Organograma de abordagem dos resultados experimentais.

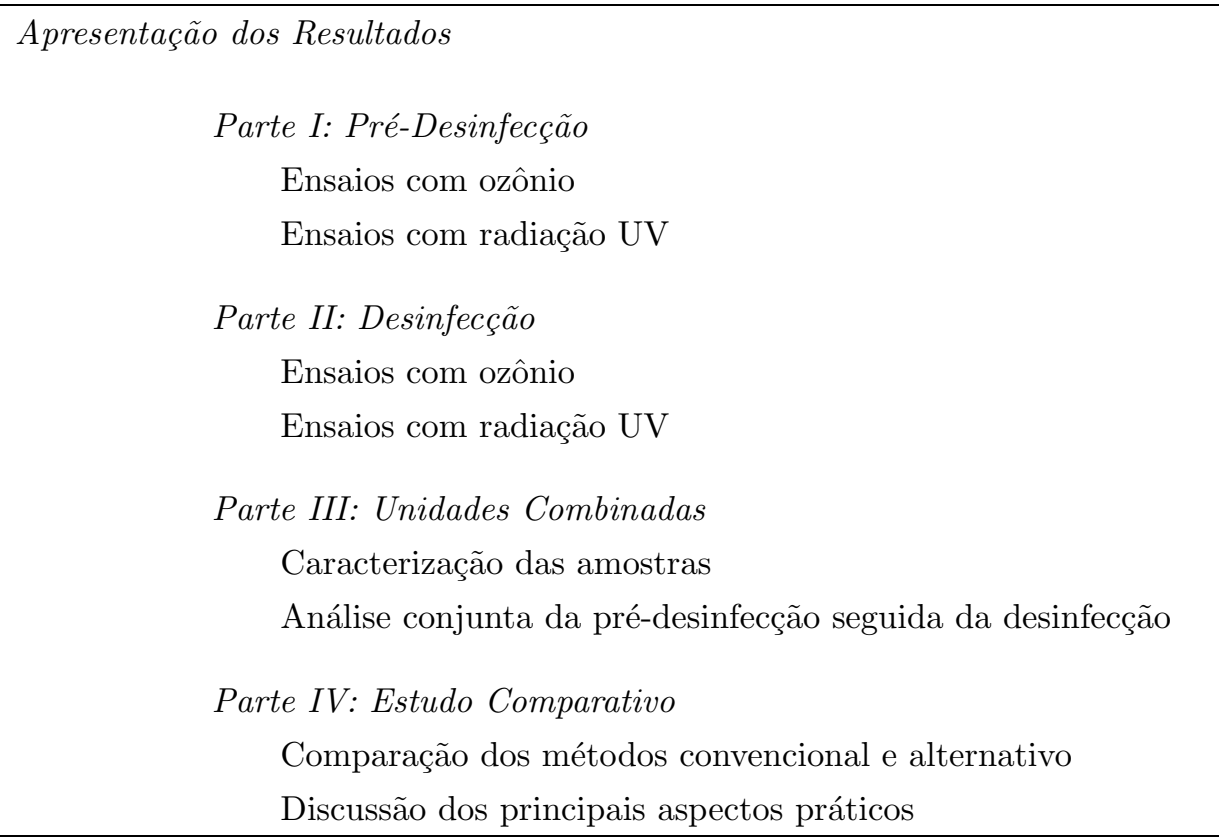


Os resultados das análises físico-químicas e dos exames microbiológicos estão agrupados em duas condições de estudo: unidade 1 - método convencional, unidade 2 - método alternativo combinado, ambas classificadas ainda segundo a espécie de agente aplicado. As várias combinações de agente químico e físico estão identificadas no texto como sendo:

\begin{tabular}{lll}
\hline Unidade 1: & $-/ \mathrm{O}_{3}$ & \\
& $-/ \mathrm{UV}$ & \\
& & \\
Unidade 2: & $\mathrm{O}_{3} / \mathrm{O}_{3}$ & $\mathrm{UV} / \mathrm{O}_{3}$ \\
& $\mathrm{O}_{3} / \mathrm{UV}$ & $\mathrm{UV} / \mathrm{UV}$ \\
\hline
\end{tabular}

\subsection{Parte I: Pré-Desinfecção}

\subsubsection{Ozonização}

Para os experimentos correspondentes à primeira etapa, a capacidade de produção do equipamento gerador de ozônio foi calculada em $6,9 \mathrm{~g} \mathrm{O}_{3} / \mathrm{h}$, enquanto as vazões de $\mathrm{O}_{3}$ e do efluente na entrada da unidade de desinfecção foram estimadas em $9 \mathrm{~L} / \mathrm{min}$ e $6,8 \mathrm{~m}^{3} / \mathrm{h}$, respectivamente. A partir destes dados foi determinada em 1,0mg $\mathrm{O}_{3} / \mathrm{L}$ a dosagem teórica de $\mathrm{O}_{3}$ aplicada na câmara de contato para a demanda das reações de oxidação e desinfecção.

Embora a elevada vazão de efluente seja necessária para promover o arraste da fase gasosa e sua dissolução na fase líquida, por outro lado, este mesmo parâmetro foi responsável pela grande turbulência gerada na câmara de contato, diminuindo a solubilidade do gás ozônio e interferindo na eficiência do tratamento.

Essa hipótese se apóia particularmente na liberação de odor característico do gás ozônio nas proximidades do extravasor na instalação experimental ${ }^{1}$ (Figura 4.5$)$, visto que a baixa dosagem aplicada $(1,0 \mathrm{mg} / \mathrm{L})$ deveria ser comple-

\footnotetext{
${ }^{1} \mathrm{O}$ off-gas não foi monitorado por limitações operacionais da instalação piloto.
} 
tamente absorvida pelos constituintes orgânicos e inorgânicos do esgoto. Além disso, a baixa concentração de ozônio, frente a elevada taxa de alimentação da unidade piloto, representou fator limitante para os ensaios de ozonização da etapa de pré-desinfecção.

Sendo assim, a dose efetiva de ozônio transferido para o efluente foi considerada equivalente ao valor teórico, dada a impossibilidade de determinação da fração descartada como off-gas. Neste contexto, tornou-se desnecessário mensurar a fração de ozônio residual no interior da câmara de contato já que sua presença é comumente bastante reduzida quando comparada ao próprio off-gas.

Não obstante o efeito negativo dessas considerações no entendimento desejado dos processos investigados, estes desafios, por outro lado, possibilitaram o desenvolvimento prático-científico, como resultado da busca e criação de soluções alternativas, de grande valia na vivência acadêmica.

\section{Considerações Complementares}

O equipamento gerador de ozônio utilizado na unidade experimental da etapa 1 opera sob condições bastante particulares, estabelecidas pelo fabricante. Dentre elas destaca-se a elevada vazão de efluente requerida para arraste e dissolução da fase gasosa.

A alta velocidade de circulação da mistura efluente-ozônio, no sistema de tubulação em direção à câmara de contato, favorece o transporte de parte da massa gasosa dissolvida para a atmosfera, através da saída do extravasor situado junto ao reservatório para o esgoto ozonizado (Figura 4.5). Não obstante esforços contrários, a taxa efetiva de ozônio absorvido pela fase líquida permaneceu restrita às condições operacionais de implantação da técnica.

Neste contexto, torna-se relevante ressaltar a importância de estudos futuros para a compreensão detalhada do mecanismo de associação gás-líquido, bem como do entendimento de fatores físicos potencialmente interferentes. 


\subsubsection{Radiação UV}

Nos ensaios com radiação ultravioleta a vazão de efluente anaeróbio na entrada do reator fotoquímico foi fixada em $6 \mathrm{~L} / \mathrm{min}$. A partir do volume útil do reator, calculado em 1,0L, o tempo de exposição do efluente à radiação foi estimado em 10 s.

\section{Cálculo da Intensidade de Emissão da Lâmpada}

Como base para os cálculos da intensidade média de energia emitida pela lâmpada no reator da etapa 1 em $254 \mathrm{~nm}$, foi considerada a potência luminosa média de 3,45W para o período de operação de aproximadamente 1080 horas consecutivas. Este valor surge como resultado da seqüência de ensaios actinométricos, realizados por COLETTI (2003), em unidade piloto idêntica, de modo a monitorar o desempenho da fonte luminosa ao longo do tempo de funcionamento do reator.

A seguir, a Tabela 5.2 lista os valores de potência radiante e porcentagem de emissão relativos ao tempo progressivo de funcionamento da lâmpada observados por COLETTI (2003).

Tabela 5.2: Capacidade de irradiação da lâmpada germicida com o tempo de operação.

\begin{tabular}{|c|c|c|}
\hline Tempo $^{a}(h)$ & Potência (W) & Emissão $^{b}(\%)$ \\
\hline 0,26 & 4,71 & 31,4 \\
\hline 24,26 & 3,62 & 24,1 \\
\hline 120,27 & 2,84 & 18,9 \\
\hline 1026,86 & 2,63 & 17,5 \\
\hline 2265,16 & 2,03 & 13,5 \\
\hline 4434,96 & 1,68 & 11,2 \\
\hline
\end{tabular}


A partir destas informações, a energia $I_{0}$ gerada pela lâmpada, em relação à área circular do reator fotoquímico de $26 \mathrm{~cm}^{2}$, foi estimada em $5,1 \mathrm{~mW} / \mathrm{cm}^{2}$.

Dada a complexidade de determinação da intensidade média de distribuição dos raios UV no modelo radial de reator fotoquímico, para os cálculos de dosagem onde a espessura da lâmina líquida foi fixada em $2,3 \mathrm{~cm}$, assumiu-se $I_{0}$ equivalente a $I_{M}$. Portanto, a dose de radiação ${ }^{2}$ aplicada nos ensaios de desinfecção era aproximadamente $51 \mathrm{~mW} . \mathrm{s} / \mathrm{cm}^{3}$.

Nesta fase da pesquisa não foram observadas grandes dificuldades associadas a implantação e operação da unidade piloto UV. A única intervenção necessária esteve subordinada à limpeza da lâmpada, procedimento este desempenhado semanalmente.

\subsection{Parte II: Desinfecção}

Os resultados apresentados nesta seção se referem aos ensaios de desinfecção realizados na segunda etapa da fase experimental para simulação do método de tratamento conjugado.

\subsubsection{Ensaios com Ozônio}

\section{Calibração do Equipamento Gerador de Ozônio}

A metodologia adotada na determinação da concentração de ozônio gerado consiste na utilização de diferentes vazões de ar ajustadas no rotâmetro, arbitrariamente escolhidas na escala de 10 a 160L/h, de modo a se obter uma correlação entre vazão de oxigênio aplicado e rendimento do aparelho.

A capacidade de produção do equipamento gerador de ozônio implantado na etapa 2, correspondente a oito diferentes vazões de oxigênio, está relacionada na Tabela 5.3.

\footnotetext{
${ }^{2}$ Determinada pela equação 3.19 .
} 
Tabela 5.3: Produção de ozônio correspondente a diferentes vazões de oxigênio na entrada do equipamento.

\begin{tabular}{cc}
\hline $\operatorname{Vaza\tilde {o}}^{a}(\mathrm{~L} / \mathrm{h})$ & Produção $(\mathrm{g} / \mathrm{h})$ \\
\hline 10 & 0,57 \\
20 & 0,56 \\
40 & 0,75 \\
60 & 0,98 \\
80 & 1,10 \\
100 & 1,25 \\
130 & 1,30 \\
160 & 1,56 \\
\hline
\end{tabular}

[a] Valor ajustado no rotâmetro.

Os resultados apresentados foram calculados a partir de dados experimentais aplicados à equação (4.1).

Desse modo, foi possível reproduzir graficamente o comportamento do gerador de ozônio, no intervalo de vazão analisado, e definir a melhor representação matemática para os dois parâmetros. A expressão resultante é definida pela equação (5.1).

$$
y=0,0067 \cdot x+0,5031
$$

$y$ : Vazão de $\mathrm{O}_{2}$ lida no rotâmetro $(\mathrm{L} / \mathrm{h})$;

$x$ : Capacidade do equipamento (g de $\left.\mathrm{O}_{3} / \mathrm{h}\right)$.

Esta relação permite, portanto, estabelecer a concentração de ozônio presente na fase gasosa em diferentes vazões de oxigênio, cálculo este fundamental para a estimativa da dosagem de ozônio aplicada no meio reacional para os ensaios de desinfecção.

Assim, substituindo as variáveis dosagem de ozônio e tempo de contato na equação 4.2 tem-se a produção do equipamento, cujo resultado, por sua vez, pode ser relacionado à vazão de oxigênio pela equação 5.1. 


\section{Dose de Ozônio}

A escolha da dosagem teórica de ozônio esteve intimamente vinculada às condições operacionais utilizadas nos procedimentos experimentais, em particular o indicador de vazão.

Embora a escala do rotâmetro permitisse selecionar a vazão de gás entre os limites 0 e 400L/h, na prática, entretanto, para vazões inferiores a 15L/h o aparelho mostrou-se pouco preciso, sofrendo oscilações periódicas, dificultando seu ajuste. Por outro lado, para os valores acima de 160L/h a velocidade de ascensão das bolhas provocou elevada turbulência da massa líquida na câmara de contato, comprometendo, assim, a eficiência de transferência gás-líquido.

Em termos práticos, para sistemas com dispersão da fase gasosa semelhantes ao utilizado, vazões superiores a 150L/h são desaconselháveis pois, neste caso, a dimensão das bolhas formadas favorece a criação de rotas preferenciais de escoamento, reduzindo, assim, a taxa de absorção do gás pela fase líquida. Além disso, a velocidade de transporte do gás longitudinalmente à câmara de ozonização é consideravelmente maior, reduzindo o tempo de contato disponível para as reações envolvidas e elevando a concentração de ozônio no off-gas.

A dose efetiva de ozônio para as reações de oxidação e desinfecção foi determinada substituindo as concentrações de ozônio aplicado, residual e off-gas na equação (3.5). O resultado dos cálculos está indicado na Tabela 5.4.

A fração de ozônio residual dissolvida no efluente se manteve em torno de $1,0 \mathrm{mg}$ de $\mathrm{O}_{3} / \mathrm{L}$, para as três vazões investigadas $(15,50$ e $100 \mathrm{~L} / \mathrm{h})$, isto é, seu valor não foi afetado pela variação da vazão. Para o off-gas acumulado no frasco lavador (Figura 4.8) foi determinado o valor médio de 18,0mg (+/- 2mg) de $\mathrm{O}_{3} / \mathrm{L}$, representando uma dosagem real próxima de $60 \%$, em relação ao valor aplicado.

A diminuiçao na taxa de ozônio absorvido, quando comparada ao valor teórico aplicado, pode estar associada principalmente a limitações práticas como configuração e dimensionamento da câmara de contato, além do próprio mecanismo adotado para a dispersão de bolhas. 
Tabela 5.4: Valores de vazão e dose efetiva relativos aos ensaios 1,2 e $3\left(\mathrm{O}_{3}\right)$.

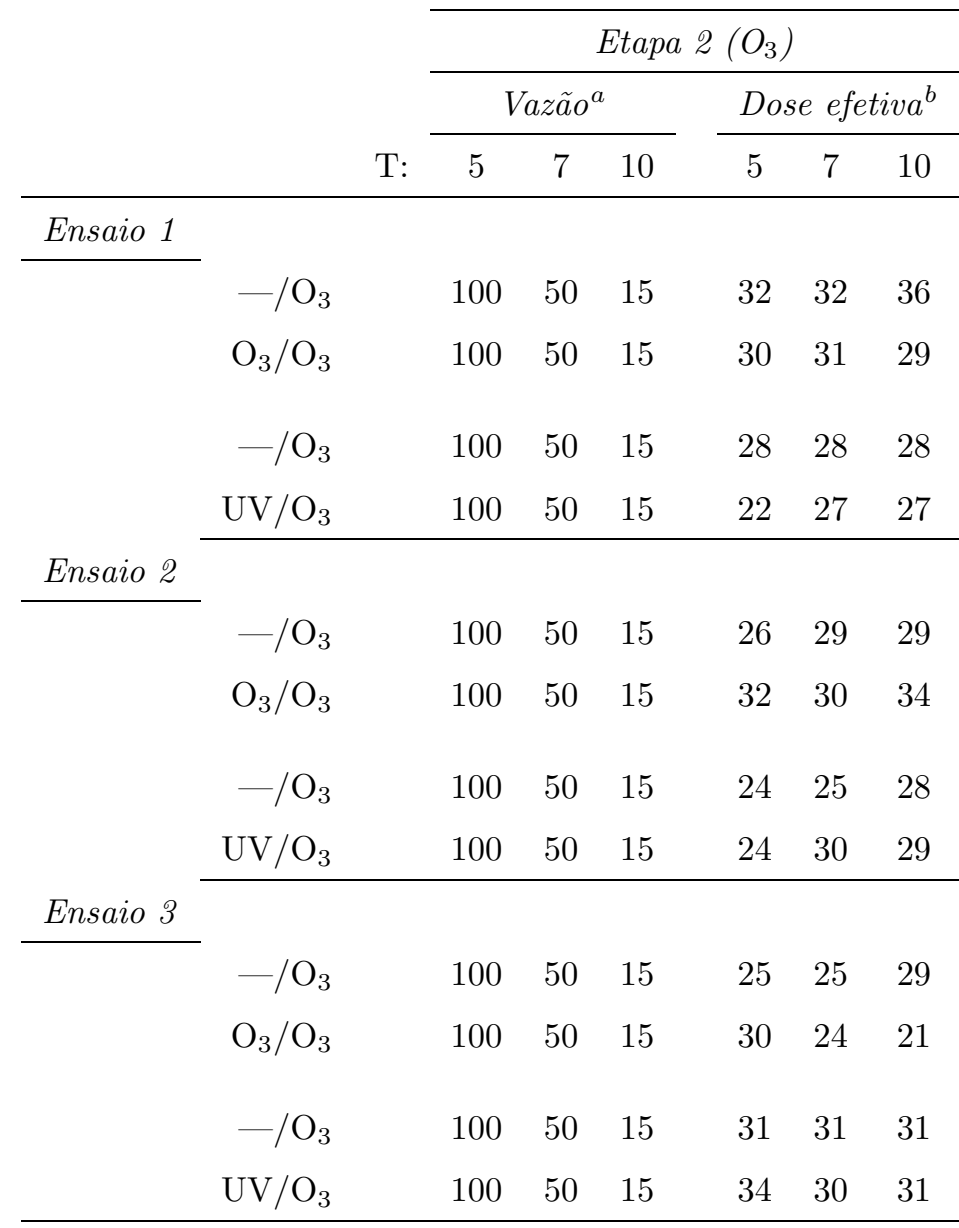

T: Tempo de contato (min).

Dose teórica: $50 \mathrm{mg}$ de $\mathrm{O}_{3} / \mathrm{L}$.

[a] Vazão de oxigênio ajustada no rotâmetro, em L/h.

[b] Valor calculado a partir da equação (3.5), em mg/L. 


\subsubsection{Ensaios com Radiação UV}

\section{Intensidade de Irradiação do Sistema Fotoquímico}

Os dados da intensidade pontual de radiação UV fornecida pelo radiômetro no sistema de lâmpadas da etapa 2 estão indicados na Tabela 5.5. Os pontos representados pelo intervalo de 1 a 9 se referem às várias posições do sensor fixado no interior da câmara de reação, conforme apresentado na Figura 4.12.

Tabela 5.5: Intensidade pontual de radiação UV no reator fotoquímico.

\begin{tabular}{cc}
\hline Ponto analisado & Intensidade $^{a}$ \\
\hline 1 & 4,81 \\
2 & 5,06 \\
3 & 4,30 \\
4 & 4,85 \\
5 & 4,97 \\
6 & 4,14 \\
7 & 4,21 \\
8 & 4,42 \\
9 & 3,60 \\
\hline
\end{tabular}

[a] Leitura no radiômetro, em $\mathrm{mW} / \mathrm{cm}^{2}$.

As informações da tabela permitem estimar em $4,5 \mathrm{~mW} / \mathrm{cm}^{2}$ a intensidade de energia $I_{0}$ liberada pela fonte ultravioleta.

Portanto, a intensidade média $I_{M}$ distribuída na camada líquida pode ser determinada substituindo os valores ${ }^{3}$ de $L, A$ e $I_{0}$ na equação (3.15). A Tabela 5.6 relaciona o resultado da leitura de absorbância em 254nm e dos cálculos da intensidade média e dose efetiva relativos aos três ensaios com radiação UV.

\footnotetext{
${ }^{3}$ Dados operacionais apresentados na Tabela 4.3.
} 
Tabela 5.6: Valores de absorbância, intensidade média e dose efetiva relativos aos ensaios 1, 2 e 3 (UV).

\begin{tabular}{|c|c|c|c|c|c|c|c|c|c|c|c|}
\hline & & \multirow[b]{4}{*}{$\mathrm{T}:$} & \multirow{2}{*}{\multicolumn{9}{|c|}{ Etapa $2(U V)$}} \\
\hline & & & & & & & & & & & \\
\hline & & & \multicolumn{3}{|c|}{ Absorbância } & \multicolumn{3}{|c|}{ Intensidade $^{a}$} & \multicolumn{3}{|c|}{ Dose efetiva ${ }^{b}$} \\
\hline & & & 30 & 60 & 120 & 30 & 60 & 120 & 30 & 60 & 120 \\
\hline \multicolumn{12}{|l|}{ Ensaio 1} \\
\hline & $-/ \mathrm{UV}$ & & 0,234 & 0,221 & 0,191 & 2,2 & 2,3 & 2,4 & 66 & 138 & 288 \\
\hline & $\mathrm{O}_{3} / \mathrm{UV}$ & & 0,203 & 0,168 & 0,159 & 2,4 & 2,5 & 2,7 & 72 & 150 & 324 \\
\hline & $-/ \mathrm{UV}$ & & 0,278 & 0,301 & 0,291 & 2,0 & 1,9 & 1,9 & 60 & 114 & 228 \\
\hline & $\mathrm{UV} / \mathrm{UV}$ & & 0,318 & 0,320 & 0,317 & 1,8 & 1,8 & 1,8 & 54 & 108 & 216 \\
\hline \multicolumn{12}{|l|}{ Ensaio 2} \\
\hline & $-/ \mathrm{UV}$ & & 0,250 & 0,226 & 0,230 & 2,1 & 2,3 & 2,2 & 63 & 138 & 264 \\
\hline & $\mathrm{O}_{3} / \mathrm{UV}$ & & 0,173 & 0,091 & 0,132 & 2,6 & 3,3 & 2,9 & 78 & 198 & 348 \\
\hline & $-/ \mathrm{UV}$ & & 0,267 & 0,292 & 0,280 & 2,0 & 1,9 & 2,0 & 61 & 116 & 239 \\
\hline & $\mathrm{UV} / \mathrm{UV}$ & & 0,309 & 0,298 & 0,301 & 1,9 & 1,9 & 1,9 & 55 & 115 & 227 \\
\hline \multicolumn{12}{|l|}{ Ensaio 3} \\
\hline & $-/ \mathrm{UV}$ & & 0,227 & 0,315 & 0,317 & 2,2 & 1,8 & 1,8 & 66 & 108 & 216 \\
\hline & $\mathrm{O}_{3} / \mathrm{UV}$ & & 0,317 & 0,233 & 0,230 & 1,8 & 2,2 & 2,2 & 54 & 132 & 264 \\
\hline
\end{tabular}

T: Tempo de contato (s). Ensaio 3 UV/UV não foi realizado.

[a] Intensidade média $I_{M}$ na lâmina líquida, em $\mathrm{mW} / \mathrm{cm}^{2}$.

[b] Valor expresso em $\mathrm{mW} . \mathrm{s} / \mathrm{cm}^{2}$. 


\subsection{Parte III: Unidades Combinadas}

Nesta seção são apresentados os resultados da caracterização físico-química e microbiológica das diversas amostras analisadas ao longo dos experimentos, possibilitando, assim, uma visão integral das unidades piloto das etapas 1 e 2 conjuntamente. Pertence ainda ao escopo desta seção as discussões e interpretações concernentes aos vários parâmetros investigados, distribuídas em ítens de modo a facilitar sua compreensão.

Devido ao grande volume de dados coletados, visto que os experimentos foram realizados em triplicata, para o desenvolvimento dos temas desta seção e apresentação de tabelas e gráficos foi selecionado como parâmetro apenas o segundo ensaio. Os demais foram incluídos no capítulo Anexo A como material suplementar.

Embora pequenas variações tenham sido observadas entre os três ensaios, em se tratando de esgoto sanitário os valores não foram significativos, o que permitiu a aproximação considerada.

\subsubsection{Caracterização das Amostras}

A partir dos resultados obtidos nos procedimentos analíticos foram elaboradas as Tabelas 8.1 a 8.11. O material compilado foi organizado de acordo com a metodologia aplicada, sendo: Tabelas 8.1, 8.2, 8.3, 8.4 - ensaio 1; Tabelas 8.5, 8.6, 8.7 e 8.8 - ensaio 2; Tabelas $8.9,8.10$ e 8.11 - ensaio $3^{4}$.

\subsubsection{Análises Físico-Químicas}

Os ítens a seguir foram elaborados a partir das informações contidas nas Tabelas 8.1 a 8.11 para estudo dos seguintes aspectos: influência da concentração de sólidos suspensos voláteis e totais, efeito da concentração de matéria oxidável, pH e alcalinidade na inativação dos indicadores Escherichia coli, coliformes totais,

\footnotetext{
${ }^{4} \mathrm{O}$ terceiro ensaio da seqüência $U V / U V$ não foi realizado.
} 
colifagos e Clostridium perfringens, para as seqüências $\mathrm{O}_{3} / \mathrm{O}_{3}, \mathrm{O}_{3} / \mathrm{UV}$, UV/O $\mathrm{O}_{3}$, $\mathrm{UV} / \mathrm{UV}$.

Nesta ordem de eventos foi investigada a pré-desinfecção seguida da desinfecção convencional, utilizando a combinação de agentes $\mathrm{O}_{3}$ e UV.

\section{Avaliação do Parâmetro DQO}

Como técnica analítica para acompanhar a variação da concentração de matéria oxidável foi adotado o parâmetro DQO. A diminuição no seu valor após a desinfecção revela que parte da massa de agente oxidante transferida para o efluente pode ter sido consumida nas reações de oxi-redução, conseqüentemente, diminuindo a eficiência das reações de inativação.

A interpretação dos dados relativos ao parâmetro DQO resultou na elaboração dos gráficos representados na Figura 5.1 (ensaio 2) ${ }^{5}$. Nesses gráficos são apresentadas as etapas 1 e 2, para os métodos convencional e alternativo, organizadas seqüencialmente.

De início nota-se a não uniformidade dos valores projetados, perfil absolutamente coerente com a composição heterogênea do esgoto sanitário. Para os ensaios com ozônio na pré-desinfecção e desinfecção não foram identificadas grandes variações em relação às demais amostras. No primeiro caso, a baixa dosagem de $\mathrm{O}_{3}$ fornecida pela unidade piloto pode ter sido a principal responsável pelo consumo desprezível de DQO. Entretanto, o mesmo não pode ser afirmado no segundo caso, cuja concentração efetiva de ozônio permaneceu próxima de 30mg/L, valor este relativamente elevado.

\footnotetext{
${ }^{5}$ Ensaio 1: Figura 8.1. Ensaio 3: Figura 8.2.
} 


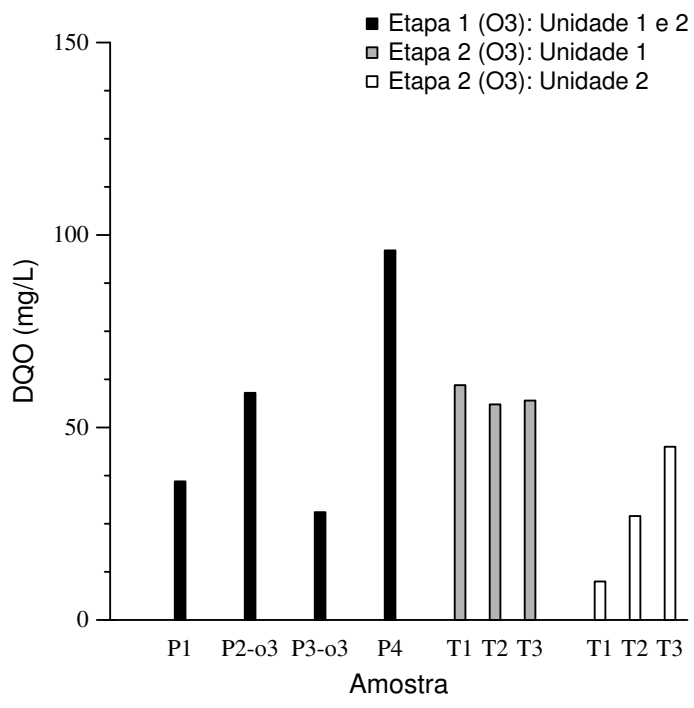

(a) $\mathrm{O}_{3} / \mathrm{O}_{3}$ (T1:5min.T2:7min.T3:10min.)

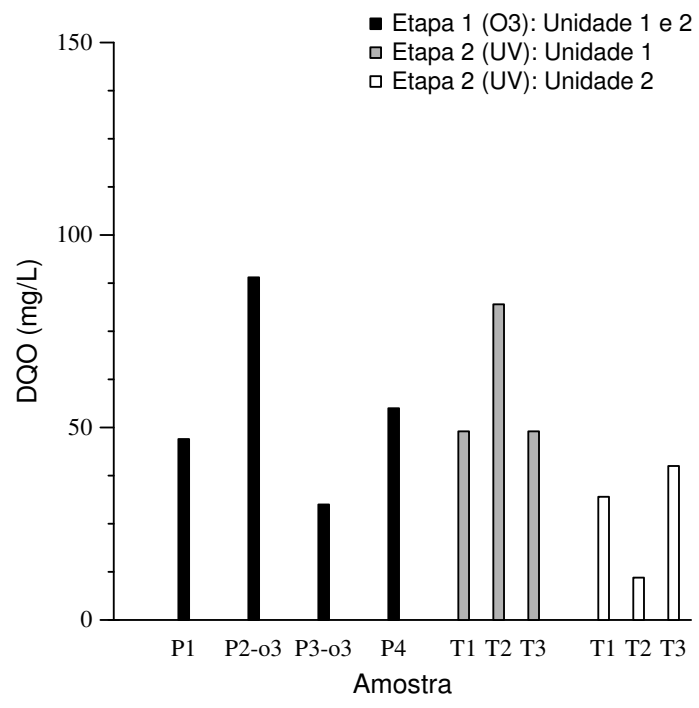

(b) $\mathrm{O}_{3} / \mathrm{UV}$ (T1:30s.T2:60s.T3:120s.)

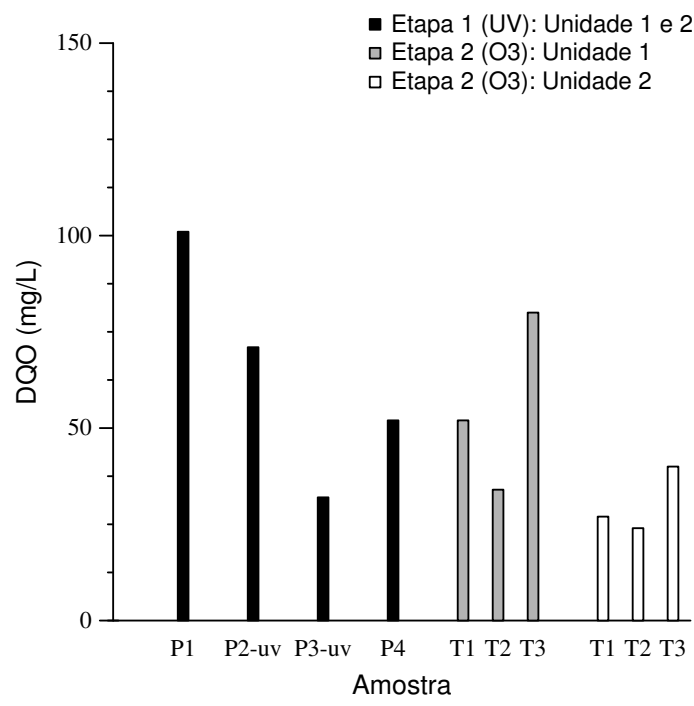

(c) $\mathrm{UV} / \mathrm{O}_{3}$ (T1:5min.T2:7min.T3:10min.)

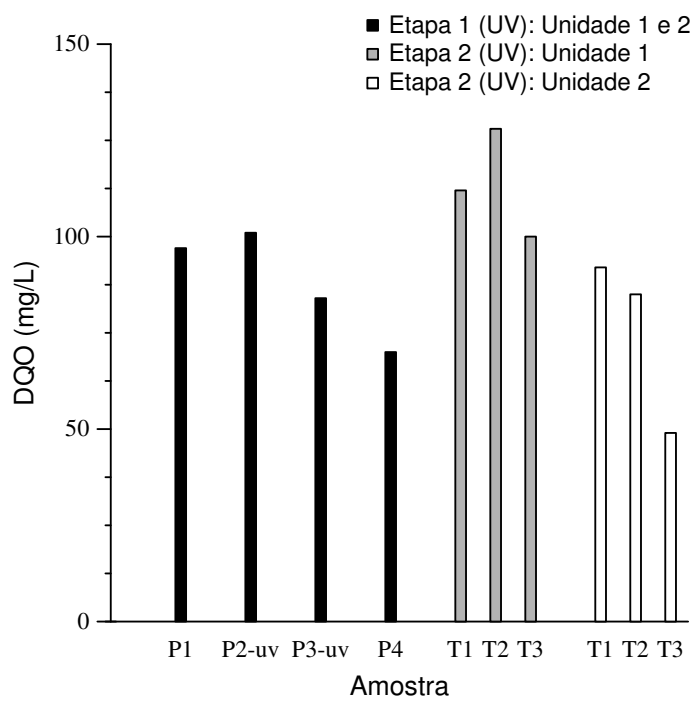

(d) UV/UV (T1:30s.T2:60s.T3:120s.)

Figura 5.1: Variação da DQO nas etapas 1 e 2 (ensaio 2).

P1: Efluente bruto. P2-o de tratamento biológico. P2-uv: Efluente após irradiação com UV. P3-uv: Efluente após irradiação com UV seguido de tratamento biológico. P4: Efluente bruto seguido de tratamento biológico. T1, T2, T3: Tempos de contato. Etapa 1: Pré-desinfecção. Etapa 2: Desinfecção. Unidade 1: método convencional. Unidade 2: Método alternativo. 
Portanto, com base nestas informações, o ozônio transferido para o efluente em ambas as unidades piloto (etapas 1 e 2) pode ter sido de fato destinado às reações de inativação. Para o embasamento dessas considerações, todavia, seriam necessárias análises específicas voltadas particularmente ao estudo do processo oxidativo, tema não pertencente aos objetivos deste trabalho.

\section{Avaliação dos Parâmetros SST e SSV}

Outro parâmetro físico-químico utilizado nesta pesquisa como indicador do comportamento do processo de desinfecção está relacionado à concentração de sólidos em suspensão, uma vez que a dimensão das partículas presentes no efluente afeta substancialmente a radiação incidente. O material particulado, neste caso, atua como anteparo impedindo a livre ação dos raios UV.

Além disso, a presença de sólidos pode favorecer a formação de agregados partícula-microrganismo dificultando ou mesmo impossibilitando que o agente oxidante alcance o alvo desejado.

Os resultados obtidos para os parâmetros sólidos suspensos totais e sólidos suspensos voláteis estão indicados nas Figuras 5.2 e 5.3 (ensaio 2) ${ }^{6}$.

Em virtude da complexidade de fatores interferentes na qualidade do esgoto sanitário, particularmente neste caso, cujo efluente utilizado era gerado na própria estação de tratamento do campus, o objetivo das representações gráficas se limita apenas à exposição das tendências de distribuição dos componentes voláteis e totais nas amostras analisadas.

Portanto, nestas ilustrações pode ser verificada a concentração de SST e SSV desde a entrada do efluente bruto (P1) até sua saída após a segunda etapa de desinfecção, pelos mecanismos convencional (unidade 1) e alternativo (unidade 2). De modo geral, os valores indicados não revelaram grandes variações na concentração de SSV, sugerindo o favorecimento das reações de inativação em relação à oxidação.

\footnotetext{
${ }^{6}$ Ensaio 1: Figuras 8.3, 8.5. Ensaio 3: Figuras 8.4, 8.6.
} 


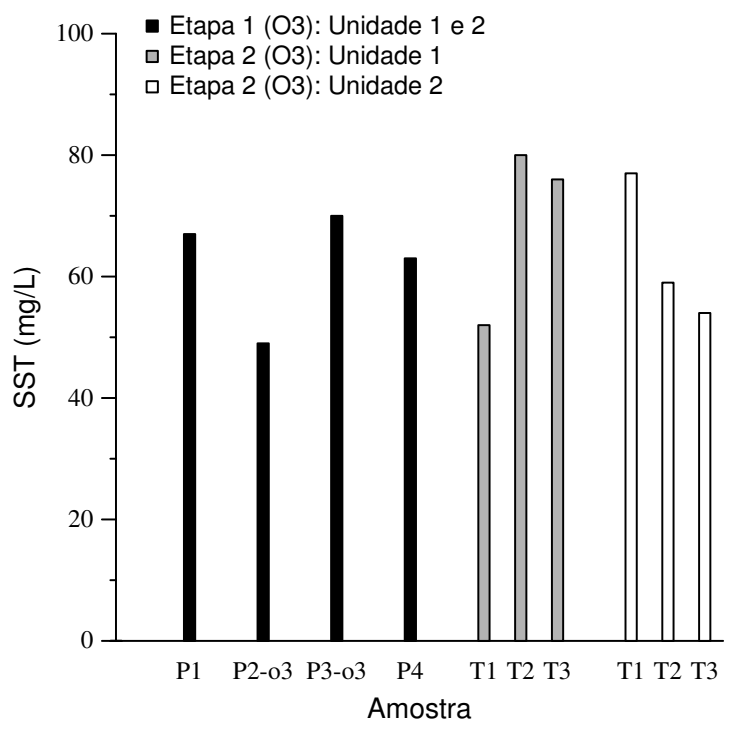

(a) $\mathrm{O}_{3} / \mathrm{O}_{3}$ (T1:5min.T2:7min.T3:10min.)

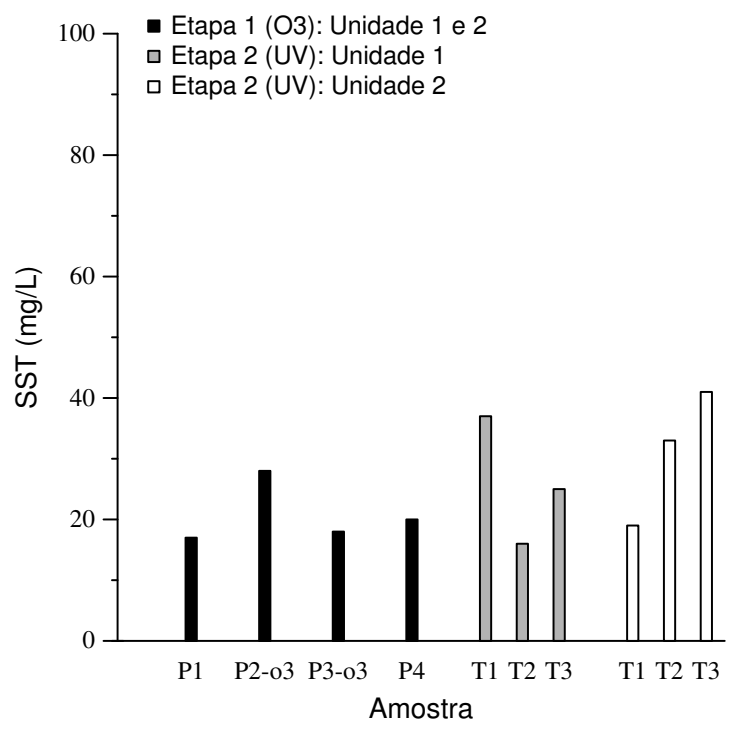

(b) $\mathrm{O}_{3} / \mathrm{UV}$ (T1:30s.T2:60s.T3:120s.)

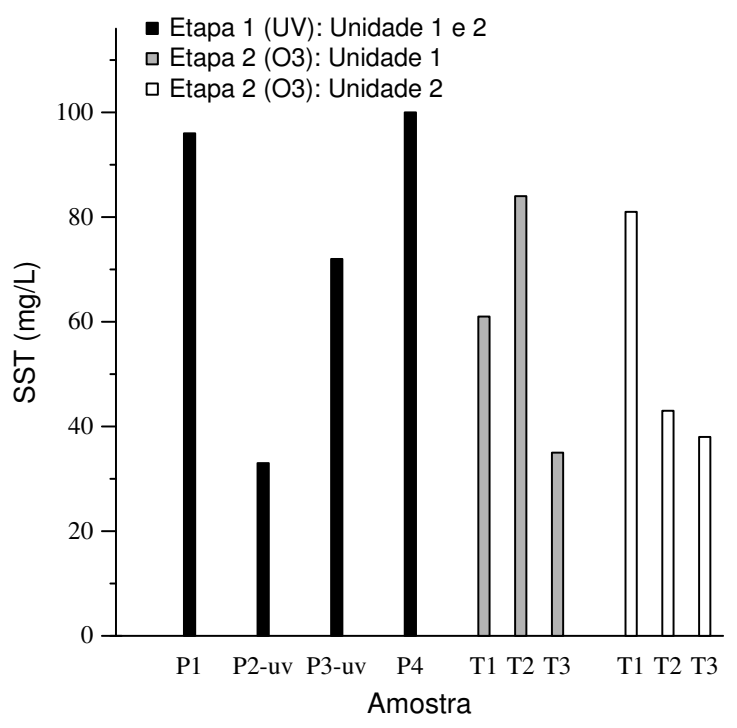

(c) $\mathrm{UV} / \mathrm{O}_{3}$ (T1:5min.T2:7min.T3:10min.)

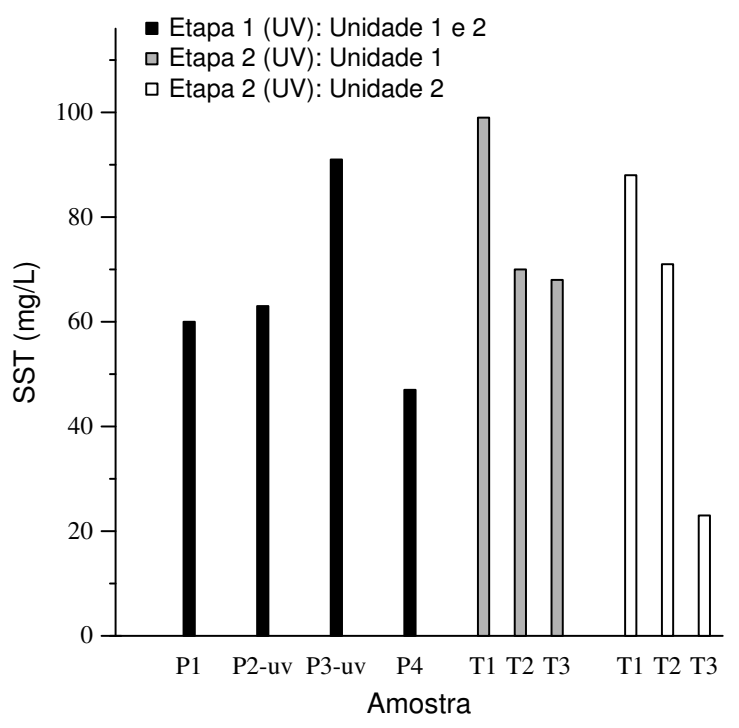

(d) UV/UV (T1:30s.T2:60s.T3:120s.)

Figura 5.2: Variação da concentração de SST nas etapas 1 e 2 (ensaio 2).

P1: Efluente bruto. P2-o ${ }_{3}$ : Efluente bruto após ozonização. P3-o 3 : Efluente ozonizado seguido de tratamento biológico. P2-uv: Efluente após irradiação com UV. P3-uv: Efluente após irradiação com UV seguido de tratamento biológico. P4: Efluente bruto seguido de tratamento biológico. T1, T2, T3: Tempos de contato. Etapa 1: Pré-desinfecção. Etapa 2: Desinfecção. Unidade 1: método convencional. Unidade 2: Método alternativo. 


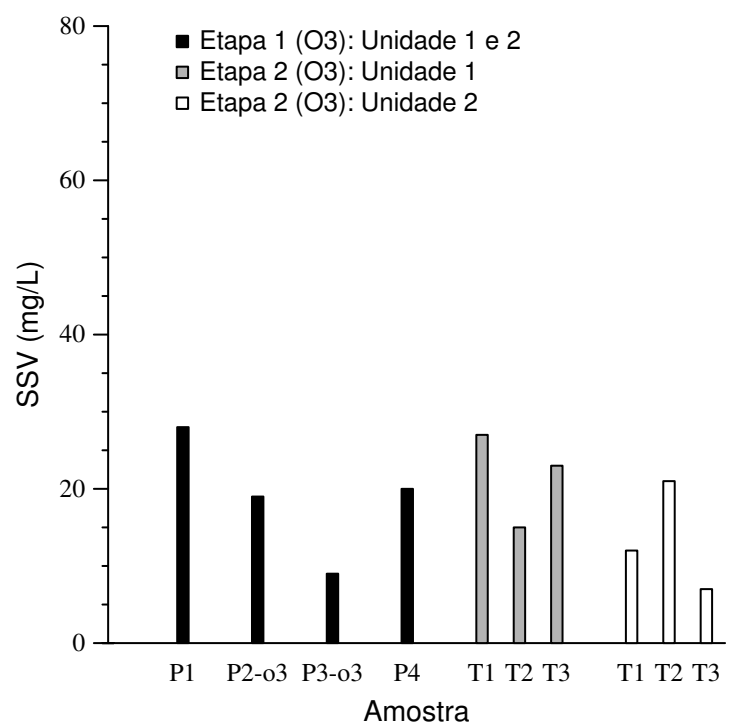

(a) $\mathrm{O}_{3} / \mathrm{O}_{3}$ (T1:5min.T2:7min.T3:10min.)

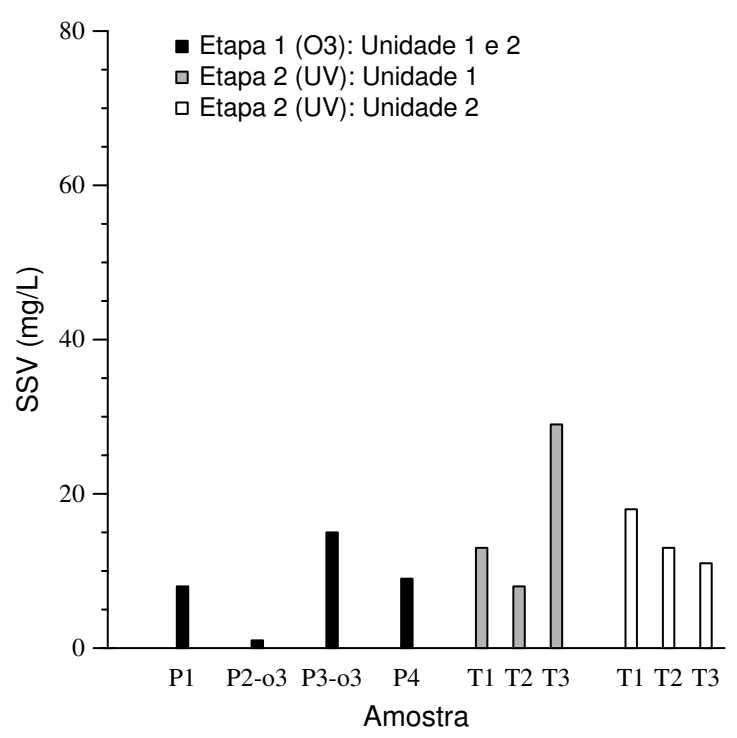

(b) $\mathrm{O}_{3} / \mathrm{UV}(\mathrm{T} 1: 30 \mathrm{~s} \cdot \mathrm{T} 2: 60 \mathrm{~s} \cdot \mathrm{T} 3: 120 \mathrm{~s}$.)

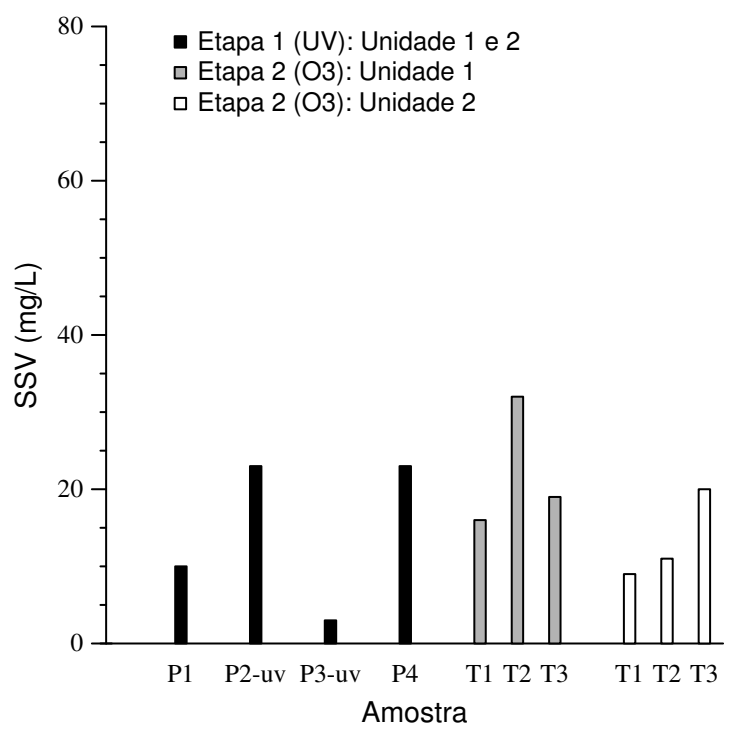

(c) $\mathrm{UV} / \mathrm{O}_{3}$ (T1:5min.T2:7min.T3:10min.)

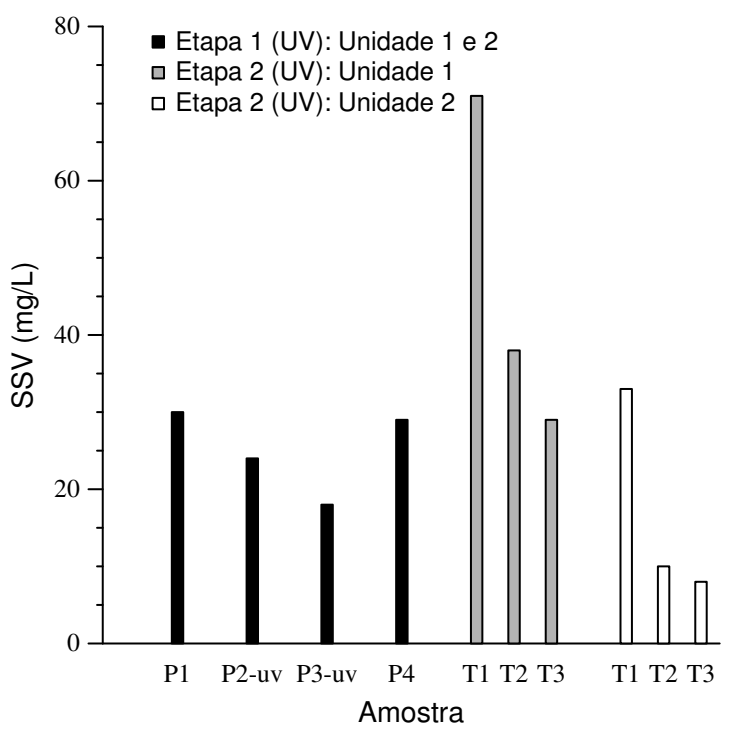

(d) UV/UV (T1:30s.T2:60s.T3:120s.)

Figura 5.3: Variação da concentração de SSV nas etapas 1 e 2 (ensaio 2).

P1: Efluente bruto. P2-o $:$ Efluente bruto após ozonização. P3-o 3 : Efluente ozonizado seguido de tratamento biológico. P2-uv: Efluente após irradiação com UV. P3-uv: Efluente após irradiação com UV seguido de tratamento biológico. P4: Efluente bruto seguido de tratamento biológico. T1, T2, T3: Tempos de contato. Etapa 1: Pré-desinfecção. Etapa 2: Desinfecção. Unidade 1: método convencional. Unidade 2: Método alternativo. 


\section{Avaliação dos Parâmetros pH e Alcalinidade}

Os parâmetros pH e alcalinidade pertencem ao conjunto de análises físicoquímicas investigadas nesta pesquisa por dois aspectos básicos: fornecer dados para o monitoramento do meio reacional objetivando a manutenção do tratamento biológico $^{7}$ e indicar o possível mecanismo de decomposição seguido na técnica de ozonização.

Concentrações relativamente elevadas da alcalinidade inibem o desenvolvimento das reações radicalares não-seletivas (mecanismo indireto), reduzindo a taxa de decomposição do $\mathrm{O}_{3}$, e, portanto, beneficiando o mecanismo direto, cujo resultado é mais significativo para a inativação de microrganismos.

De acordo com as Tabelas 8.1 a 8.11, na etapa de pré-desinfecção, que antecede o tratamento biológico, o pH se manteve entre 6,0 e 7,0, embora pequenas variações tenham sido observadas em pontos isolados. Estes valores revelam condições bastante satisfatórias para o crescimento da biomassa.

A alcalinidade, por outro lado, permaneceu elevada em praticamente todos os ensaios, podendo-se presumir, portanto, o favorecimento do mecanismo direto de ação envolvendo o ozônio molecular.

\subsubsection{Exames Microbiológicos}

As discussões apresentadas a seguir são referentes ao tema central de interesse desta pesquisa. Os indicadores de contaminação investigados foram: Escherichia coli, coliformes totais, colifagos e Clostridium perfringens.

\section{Avaliação do Parâmetro $\mathrm{N} / \mathrm{N}_{0}$}

Os resultados obtidos nos exames microbiológicos foram agrupados nas Tabelas 5.7, 5.8, 5.9 e 5.10 (ensaio 2$)^{8}$ de acordo com a seqüência de tratamento

\footnotetext{
${ }^{7}$ Durante a fase experimental foi necessária um única intervenção na unidade piloto da etapa 1 exigindo a adição de bicarbonato de sódio para correção do valor do pH.

${ }^{8}$ Ensaio 1 e 3: Tabelas 8.12, 8.13, 8.14.
} 
pré-desinfecção/desinfecção $\left(\mathrm{O}_{3} / \mathrm{O}_{3}, \mathrm{UV} / \mathrm{O}_{3}, \mathrm{O}_{3} / \mathrm{UV}, \mathrm{UV} / \mathrm{UV}\right)$ e a espécie de microrganismo. Para facilitar a análise dos dados os valores indicados estão expressos em ordem de grandeza.

Os pontos identificados pelo índice " 0 " representam frações $\mathrm{N} / \mathrm{N}_{0}$ abaixo do limite de detecção do método empregado para quantificar microrganismos com atividade metabólica e reprodutiva, sendo, portanto, consideradas ausentes.

Para o cálculo do número de indivíduos sobreviventes, isto é, $\mathrm{N} / \mathrm{N}_{0}$, foram admitidas as seguintes condições: $\mathrm{N}_{0}=\mathrm{P} 1$ e $\mathrm{N}=\mathrm{T} 1$, $\mathrm{T} 2$ e T3, onde T representa as amostras submetidas à segunda etapa de desinfecção nos três tempos de contato $^{9}$ para $\mathrm{O}_{3}$ e radiação UV nas unidades 1 e 2 .

Os resultados apresentados indicaram a redução do número de microrganismos sobreviventes à etapa 2 em todas as espécies avaliadas, com maior intensidade para os menos resistentes como Escherichia coli e colifagos, para as quatro seqüências de agente de inativação.

A análise das tabelas revelou ainda o aumento da inativação, embora pouco pronunciado, entre os sitemas combinados (pré-desinfecção/desinfecção) comparativamente ao tratamento convencional (desinfecção).

Visto que os valores de $\mathrm{N}$ para os pontos P2, P3 e P4 da etapa 1 foram bastante baixos $^{10}$ e que a maior contribuição para a inativação esteve associada à etapa 2, foram elaborados os gráficos $\log \left(\mathrm{N} / \mathrm{N}_{0}\right)$ em relação ao tempo de contato para evidenciar o comportamento dos dois métodos utilizados. Os pontos plotados foram calculados a partir da equação 4.4 aplicada às Tabelas 5.7, 5.8, 5.9 e 5.10 $(\text { ensaio } 2)^{11}$.

\footnotetext{
${ }^{9} \mathrm{P} 1$ : Efluente bruto. Unidade 1: Método convencional. Unidade 2: Método alternativo. T1, T2 e T3: 5, 7 e 10 minutos com ozônio; 30, 60 e 120 segundos com radiação UV.

${ }^{10} \mathrm{P} 2$ : Efluente bruto após pré-desinfecção. P3: Efluente após pré-desinfecção seguido de tratamento biológico. P4: Efluente bruto seguido de tratamento biológico.

${ }^{11}$ Ensaio 1 e 3: Figuras 8.12, 8.13, 8.14, 8.15.
} 
Tabela 5.7: Variação da população de Escherichia coli (ensaio 2).

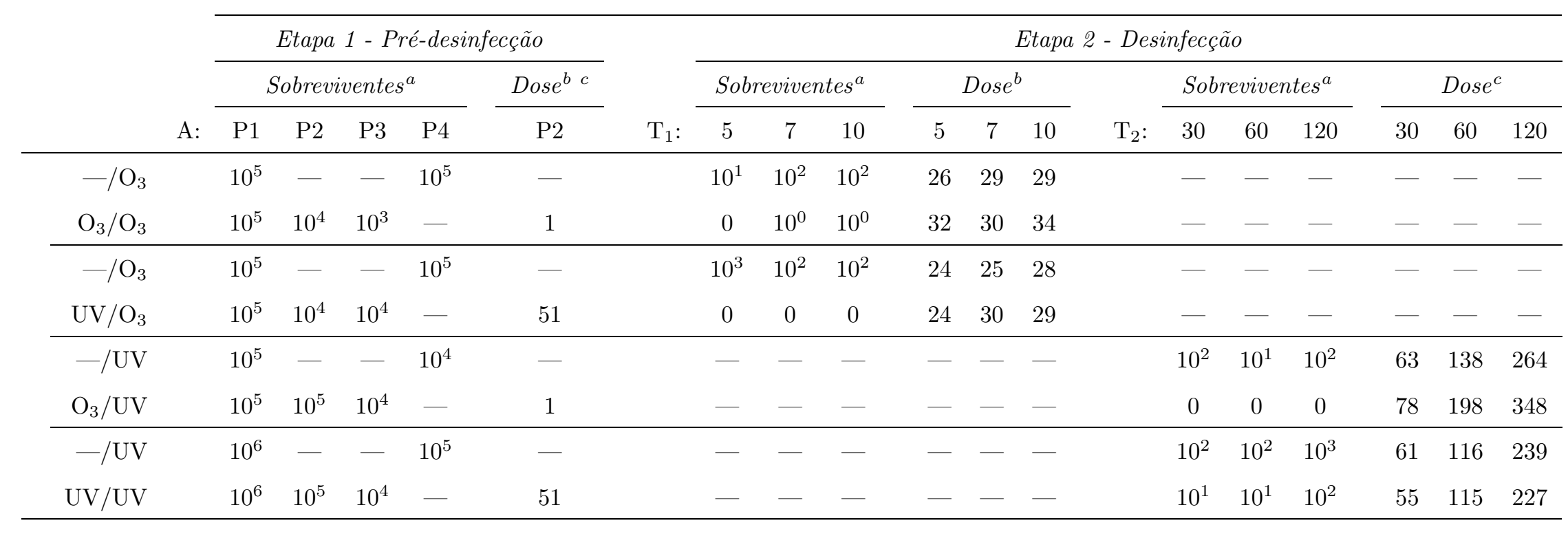

$\mathrm{T}_{1}$ : Tempo de contato, $\mathrm{O}_{3}(\mathrm{~min}) . \mathrm{T}_{2}$ : Tempo de contato, UV (s). [a] Número de sobreviventes em ordem de grandeza (UFC/100mL). [b] O 3 :mg/L. [c] UV:mW.s/cm² .

P1: Efluente bruto. P2: Efluente bruto após pré-desinfecção. P3: Efluente após pré-desinfecção seguido de tratamento biológico.

P4: Efluente bruto seguido de tratamento biológico. 
Tabela 5.8: Variação da população de colifagos (ensaio 2).

\begin{tabular}{|c|c|c|c|c|c|c|c|c|c|c|c|c|c|c|c|c|c|c|c|c|}
\hline & \multirow[b]{3}{*}{ A: } & \multicolumn{5}{|c|}{ Etapa 1 - Pré-desinfecção } & \multirow[b]{3}{*}{$\mathrm{T}_{1}:$} & \multicolumn{13}{|c|}{ Etapa 2 - Desinfecção } \\
\hline & & \multicolumn{4}{|c|}{ Sobreviventes $^{a}$} & \multirow{2}{*}{$\begin{array}{c}D_{o s e^{b c}} \\
\mathrm{P} 2\end{array}$} & & \multicolumn{3}{|c|}{ Sobreviventes ${ }^{a}$} & \multicolumn{3}{|c|}{$D_{o s e}^{b}$} & \multirow[b]{2}{*}{$\mathrm{T}_{2}$ : } & \multicolumn{3}{|c|}{ Sobreviventes $^{a}$} & \multicolumn{3}{|c|}{$D_{o s e}^{c}$} \\
\hline & & $\mathrm{P} 1$ & $\mathrm{P} 2$ & P3 & $\mathrm{P} 4$ & & & 5 & 7 & 10 & 5 & 7 & 10 & & 30 & 60 & 120 & 30 & 60 & 120 \\
\hline$-/ \mathrm{O}_{3}$ & & $10^{5}$ & - & - & $10^{5}$ & - & & $10^{3}$ & $10^{3}$ & $10^{3}$ & 26 & 29 & 29 & & - & - & - & - & - & - \\
\hline $\mathrm{O}_{3} / \mathrm{O}_{3}$ & & $10^{5}$ & $10^{5}$ & $10^{5}$ & - & 1 & & $10^{3}$ & $10^{2}$ & $10^{2}$ & 32 & 30 & 34 & & - & - & - & - & - & - \\
\hline$-/ \mathrm{O}_{3}$ & & $10^{3}$ & - & - & $10^{2}$ & - & & $10^{2}$ & $10^{2}$ & $10^{2}$ & 24 & 25 & 28 & & - & - & - & - & - & - \\
\hline $\mathrm{UV} / \mathrm{O}_{3}$ & & $10^{3}$ & $10^{2}$ & 0 & - & 51 & & 0 & 0 & 0 & 24 & 30 & 29 & & - & - & - & - & - & - \\
\hline$-/ \mathrm{UV}$ & & $10^{2}$ & - & - & $10^{2}$ & - & & - & - & - & - & - & - & & 0 & $10^{1}$ & 0 & 63 & 138 & 264 \\
\hline $\mathrm{O}_{3} / \mathrm{UV}$ & & $10^{2}$ & $10^{2}$ & $10^{2}$ & - & 1 & & - & - & - & - & - & - & & 0 & 0 & 0 & 78 & 198 & 348 \\
\hline$-/ \mathrm{UV}$ & & $10^{3}$ & - & - & $10^{3}$ & - & & - & - & - & - & - & - & & 0 & 0 & 0 & 61 & 116 & 239 \\
\hline UV/UV & & $10^{3}$ & $10^{3}$ & $10^{3}$ & - & 51 & & - & - & - & - & - & - & & 0 & 0 & 0 & 55 & 115 & 227 \\
\hline
\end{tabular}

$\mathrm{T}_{1}$ : Tempo de contato, $\mathrm{O}_{3}(\mathrm{~min}) . \mathrm{T}_{2}$ : Tempo de contato, UV (s). [a] Número de sobreviventes em ordem de grandeza (UFP/100mL). [b] O 3 :mg/L. [c] UV:mW.s/cm².

P1: Efluente bruto. P2: Efluente bruto após pré-desinfecção. P3: Efluente após pré-desinfecção seguido de tratamento biológico.

P4: Efluente bruto seguido de tratamento biológico. 
Tabela 5.9: Variação da população de Clostridium perfringens (ensaio 2).

\begin{tabular}{|c|c|c|c|c|c|c|c|c|c|c|c|c|c|c|c|c|c|c|c|c|}
\hline & \multirow[b]{3}{*}{ A: } & \multicolumn{5}{|c|}{ Etapa 1 - Pré-desinfecção } & \multicolumn{14}{|c|}{ Etapa 2 - Desinfecção } \\
\hline & & \multicolumn{4}{|c|}{ Sobreviventes $^{a}$} & \multirow{2}{*}{$\frac{D_{o s e^{b c}}}{\mathrm{P} 2}$} & \multirow[b]{2}{*}{$\mathrm{T}_{1}:$} & \multicolumn{3}{|c|}{ Sobreviventes ${ }^{a}$} & \multicolumn{3}{|c|}{$D o s e^{b}$} & \multirow[b]{2}{*}{$\mathrm{T}_{2}$ : } & \multicolumn{3}{|c|}{ Sobreviventes $^{a}$} & \multicolumn{3}{|c|}{$D_{o s e}^{c}$} \\
\hline & & $\mathrm{P} 1$ & $\mathrm{P} 2$ & P3 & $\mathrm{P} 4$ & & & 5 & 7 & 10 & 5 & 7 & 10 & & 30 & 60 & 120 & 30 & 60 & 120 \\
\hline$-/ \mathrm{O}_{3}$ & & $10^{3}$ & - & - & $10^{3}$ & - & & $10^{3}$ & $10^{1}$ & $10^{1}$ & 26 & 29 & 29 & & - & - & - & - & - & - \\
\hline $\mathrm{O}_{3} / \mathrm{O}_{3}$ & & $10^{3}$ & $10^{3}$ & $10^{3}$ & - & 1 & & $10^{1}$ & $10^{1}$ & $10^{1}$ & 32 & 30 & 34 & & - & - & - & - & - & - \\
\hline$-/ \mathrm{O}_{3}$ & & $10^{3}$ & - & - & $10^{3}$ & - & & $10^{2}$ & $10^{2}$ & $10^{2}$ & 24 & 25 & 28 & & - & - & - & - & - & - \\
\hline $\mathrm{UV} / \mathrm{O}_{3}$ & & $10^{3}$ & $10^{3}$ & $10^{2}$ & - & 51 & & $10^{1}$ & $10^{1}$ & $10^{1}$ & 24 & 30 & 29 & & - & - & - & - & - & - \\
\hline$-/ \mathrm{UV}$ & & $10^{3}$ & - & - & $10^{3}$ & - & & - & - & - & - & - & - & & $10^{2}$ & $10^{2}$ & $10^{2}$ & 63 & 138 & 264 \\
\hline $\mathrm{O}_{3} / \mathrm{UV}$ & & $10^{3}$ & $10^{3}$ & $10^{2}$ & - & 1 & & - & - & - & - & - & - & & $10^{2}$ & $10^{1}$ & $10^{1}$ & 78 & 198 & 348 \\
\hline$-/ \mathrm{UV}$ & & $10^{3}$ & - & - & $10^{3}$ & - & & - & - & - & - & - & - & & $10^{2}$ & $10^{3}$ & $10^{2}$ & 61 & 116 & 239 \\
\hline $\mathrm{UV} / \mathrm{UV}$ & & $10^{3}$ & $10^{3}$ & $10^{2}$ & - & 51 & & - & - & - & - & - & - & & $10^{1}$ & $10^{1}$ & $10^{2}$ & 55 & 115 & 227 \\
\hline
\end{tabular}

$\mathrm{T}_{1}$ : Tempo de contato, $\mathrm{O}_{3}(\mathrm{~min}) . \mathrm{T}_{2}$ : Tempo de contato, UV (s). [a] Número de sobreviventes em ordem de grandeza (NMP/100mL). [b] O 3 :mg/L. [c] UV:mW.s/cm².

P1: Efluente bruto. P2: Efluente bruto após pré-desinfecção. P3: Efluente após pré-desinfecção seguido de tratamento biológico.

P4: Efluente bruto seguido de tratamento biológico. 
Tabela 5.10: Variação da população de coliformes totais (ensaio 2).

\begin{tabular}{|c|c|c|c|c|c|c|c|c|c|c|c|c|c|c|c|c|c|c|c|c|}
\hline & \multicolumn{6}{|c|}{ Etapa 1 - Pré-desinfecção } & \multirow[b]{3}{*}{$\mathrm{T}_{1}:$} & \multicolumn{13}{|c|}{ Etapa 2 - Desinfecção } \\
\hline & \multirow[b]{2}{*}{ A: } & \multicolumn{4}{|c|}{ Sobreviventes $^{a}$} & \multirow{2}{*}{$\begin{array}{c}\text { Dose }^{b c}{ }^{c} \\
\text { P2 }\end{array}$} & & \multicolumn{3}{|c|}{ Sobreviventes ${ }^{a}$} & \multicolumn{3}{|c|}{$D o s e^{b}$} & \multirow[b]{2}{*}{$\mathrm{T}_{2}:$} & \multicolumn{3}{|c|}{ Sobreviventes ${ }^{a}$} & \multicolumn{3}{|c|}{ Dose $e^{c}$} \\
\hline & & $\mathrm{P} 1$ & P2 & P3 & $\mathrm{P} 4$ & & & 5 & 7 & 10 & 5 & 7 & 10 & & 30 & 60 & 120 & 30 & 60 & 120 \\
\hline$-/ \mathrm{O}_{3}$ & & $10^{6}$ & - & - & $10^{6}$ & - & & $10^{4}$ & $10^{3}$ & $10^{4}$ & 26 & 29 & 29 & & - & - & - & - & - & - \\
\hline $\mathrm{O}_{3} / \mathrm{O}_{3}$ & & $10^{6}$ & $10^{5}$ & $10^{5}$ & - & 1 & & $10^{1}$ & $10^{1}$ & $10^{2}$ & 32 & 30 & 34 & & - & - & - & - & - & - \\
\hline$-/ \mathrm{O}_{3}$ & & $10^{7}$ & - & - & $10^{7}$ & - & & $10^{4}$ & $10^{4}$ & $10^{4}$ & 24 & 25 & 28 & & - & - & - & - & - & - \\
\hline $\mathrm{UV} / \mathrm{O}_{3}$ & & $10^{7}$ & $10^{7}$ & $10^{6}$ & - & 51 & & $10^{4}$ & $10^{3}$ & $10^{3}$ & 24 & 30 & 29 & & - & - & - & - & - & - \\
\hline$-/ \mathrm{UV}$ & & $10^{6}$ & - & - & $10^{6}$ & - & & - & - & - & - & - & - & & $10^{3}$ & $10^{3}$ & $10^{3}$ & 63 & 138 & 264 \\
\hline $\mathrm{O}_{3} / \mathrm{UV}$ & & $10^{6}$ & $10^{6}$ & $10^{5}$ & - & 1 & & - & - & - & - & - & - & & $10^{3}$ & $10^{3}$ & $10^{3}$ & 78 & 198 & 348 \\
\hline$-/ \mathrm{UV}$ & & $10^{6}$ & - & - & $10^{6}$ & - & & - & - & - & - & - & - & & $10^{4}$ & $10^{4}$ & $10^{4}$ & 61 & 116 & 239 \\
\hline $\mathrm{UV} / \mathrm{UV}$ & & $10^{6}$ & $10^{6}$ & $10^{6}$ & - & 51 & & - & - & - & - & - & - & & $10^{3}$ & $10^{2}$ & $10^{3}$ & 55 & 115 & 227 \\
\hline
\end{tabular}

$\mathrm{T}_{1}$ : Tempo de contato, $\mathrm{O}_{3}(\mathrm{~min}) . \mathrm{T}_{2}$ : Tempo de contato, UV (s). [a] Número de sobreviventes em ordem de grandeza (UFC/100mL). [b] O 3 :mg/L. [c] UV:mW.s/cm² .

P1: Efluente bruto. P2: Efluente bruto após pré-desinfecção. P3: Efluente após pré-desinfecção seguido de tratamento biológico.

P4: Efluente bruto seguido de tratamento biológico. 
A tendência no comportamento dos quatro indicadores examinados frente à desinfecção com os métodos convencional e alternativo está representada nas Figuras $5.4,5.5,5.6$ e 5.7 (ensaio 2$)^{12}$.

As curvas traçadas foram ajustadas de modo a proporcionarem as melhores representações de distribuição dos pontos. Os pontos situados nas regiões muito afastadas da curva podem estar associados à dificuldade em se obter alíquotas absolutamente representativas das amostras em análise, já que o método de exame microbiológico utiliza diluições da ordem de 5 a 6 vezes do seu valor inicial. Além disso, as pequenas variações de inativação observadas entre os ensaios podem decorrer de oscilações na qualidade do efluente bruto proveniente da etapa 1 e ainda de flutuações na concentração de ozônio produzido pelo equipamento tanto na etapa 1 como 2 .

Nessas figuras estão plotadas comparativamente as curvas relativas à unidade 1, com um único estágio, e unidade 2, com dois estágios de desinfecção, para cada espécie investigada. O acompanhamento das linhas de tendência, em cada caso, fornece subsídios para se acreditar na verossimilhança da hipótese originalmente formulada a cerca do sistema combinado pré-desinfecção/desinfecção.

Nos ensaios com Escherichia coli, por exemplo, na unidade 2 foi atingido $1 \log$ acima do valor correspondente à unidade 1, para as mesmas condições experimentais, como mostra a Figura $5.4^{13}$. Mesmo indicadores mais resistentes como Clostridium perfringens obtiveram redução de aproximadamente 1 log em relação ao método alternativo (Figura 5.6).

Estes resultados podem estar associados ao enfraquecimento das células dos microrganismos expostos à pre-desinfecção, gerando, assim, indivíduos menos resistentes e mais facilmente eliminados na etapa seguinte de desinfecção convencional.

\footnotetext{
${ }^{12}$ Ensaio 1: Figuras 8.7, 8.8, 8.9, 8.10. Ensaio 3: Figuras 8.11, 8.12, 8.13, 8.14.

${ }^{13} \mathrm{O}$ mesmo foi observado nos ensaios 1 e 3 .
} 


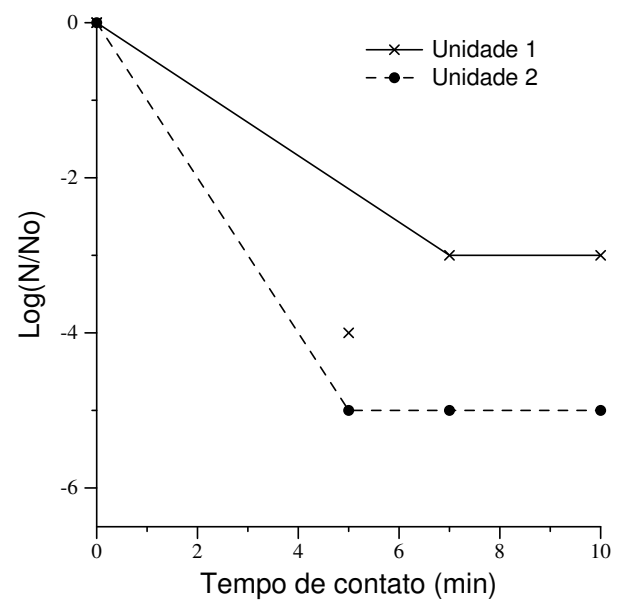

(a) $\mathrm{O}_{3} / \mathrm{O}_{3}$

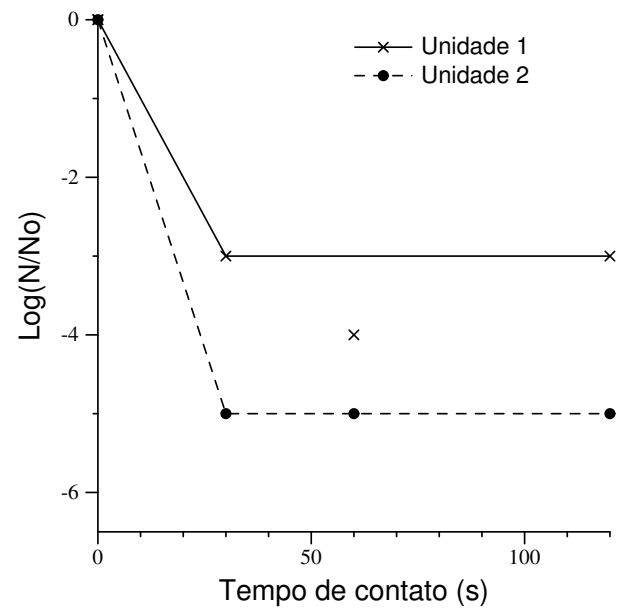

(c) $\mathrm{O}_{3} / \mathrm{UV}$

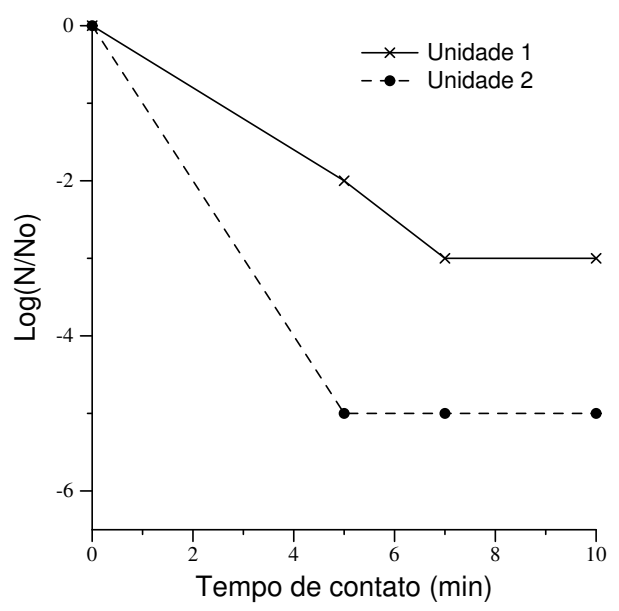

(b) $\mathrm{UV} / \mathrm{O}_{3}$

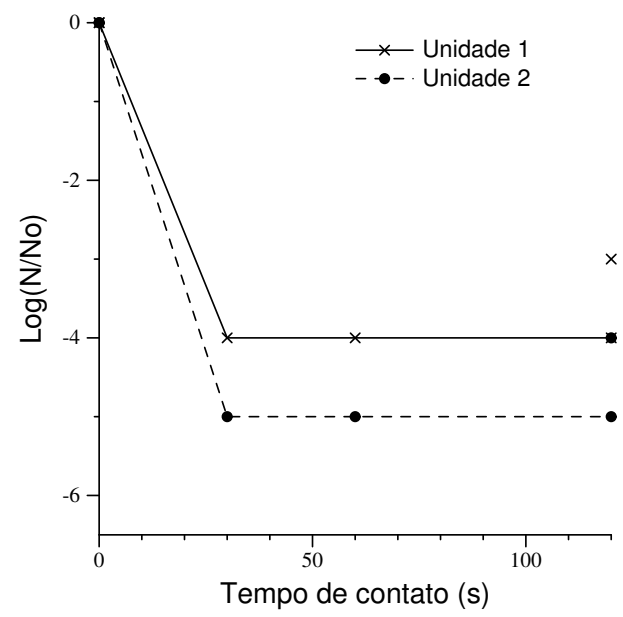

(d) $\mathrm{UV} / \mathrm{UV}$

Figura 5.4: Variação da população de E. coli na etapa 2 (ensaio 2).

Unidade 1: Método convencional. Unidade 2: Método alternativo. $\mathrm{O}_{3}: 5,7$ e 10 minutos. UV: 30, 60 e 120 segundos. 


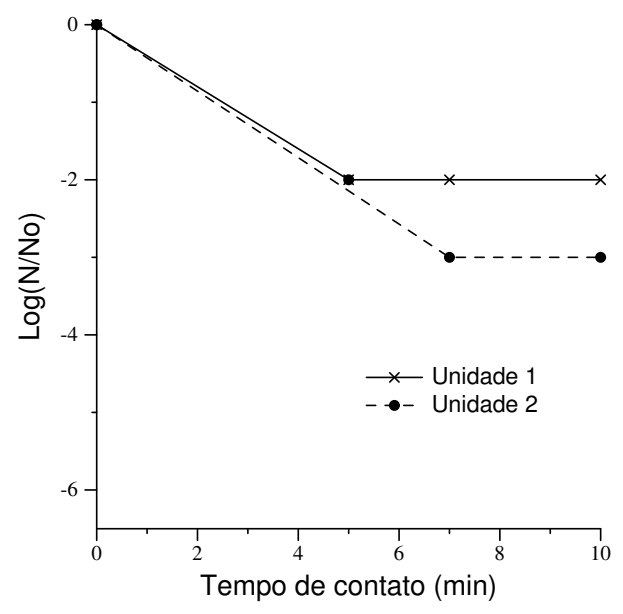

(a) $\mathrm{O}_{3} / \mathrm{O}_{3}$

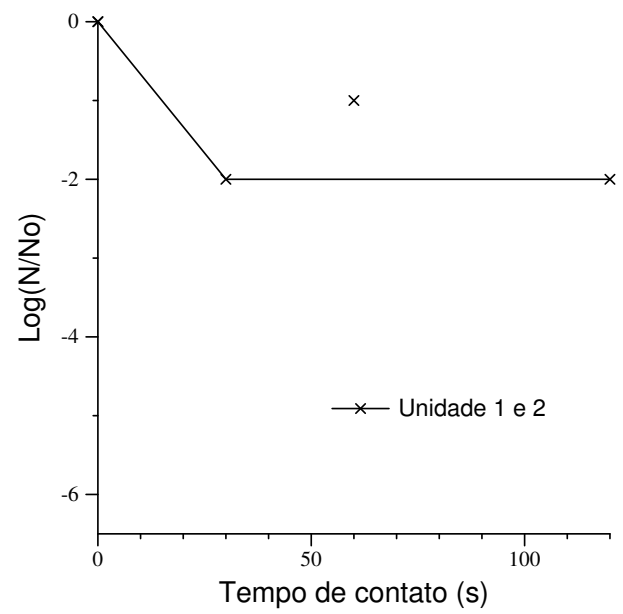

(c) $\mathrm{O}_{3} / \mathrm{UV}$

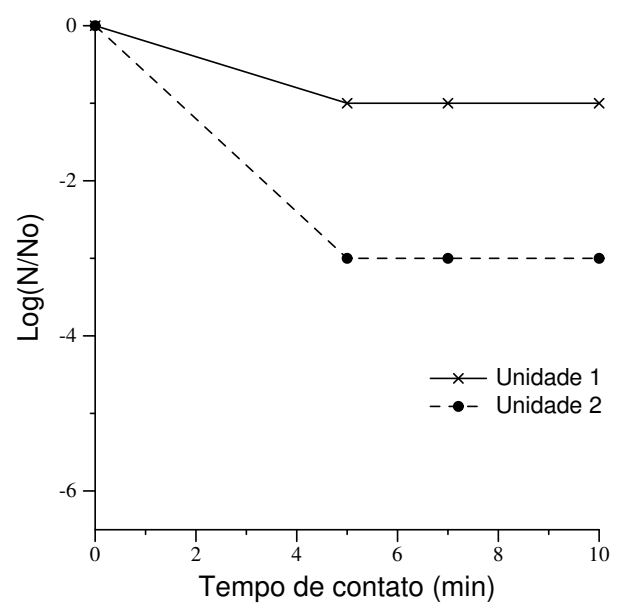

(b) $\mathrm{UV} / \mathrm{O}_{3}$

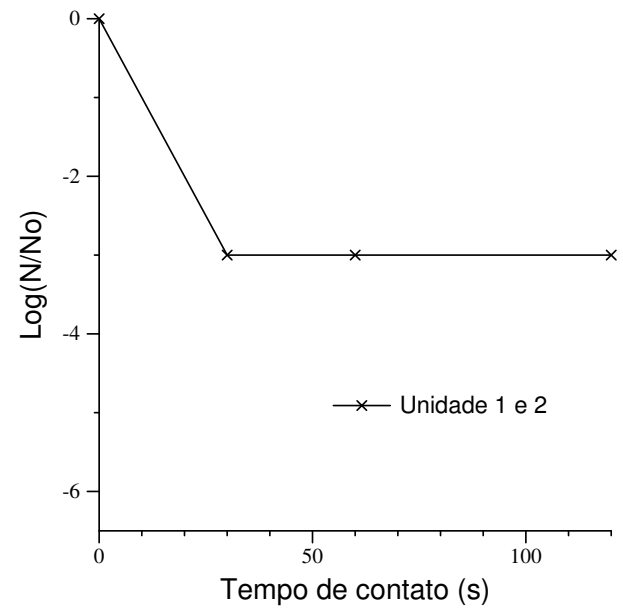

(d) $\mathrm{UV} / \mathrm{UV}$

Figura 5.5: Variação da população de colifagos na etapa 2 (ensaio 2).

Unidade 1: Método convencional. Unidade 2: Método alternativo. $\mathrm{O}_{3}: 5,7$ e 10 minutos. UV: 30, 60 e 120 segundos. 


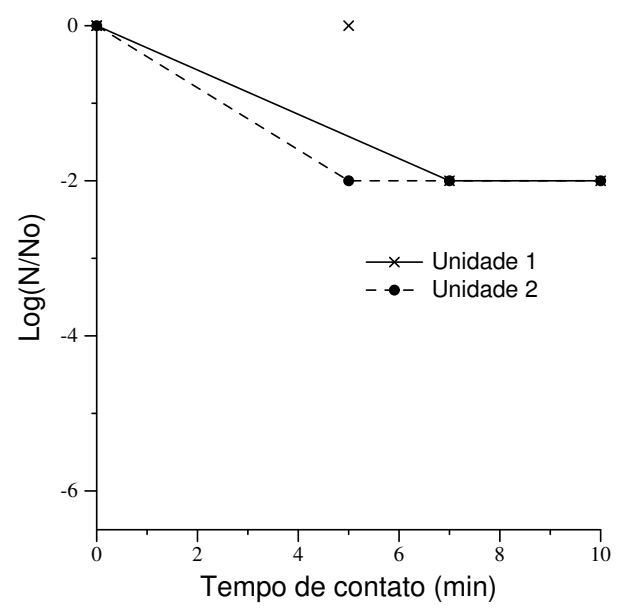

(a) $\mathrm{O}_{3} / \mathrm{O}_{3}$

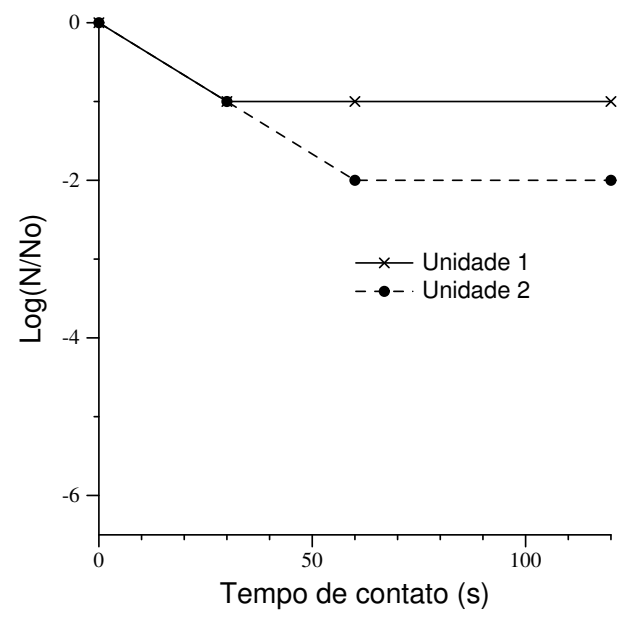

(c) $\mathrm{O}_{3} / \mathrm{UV}$

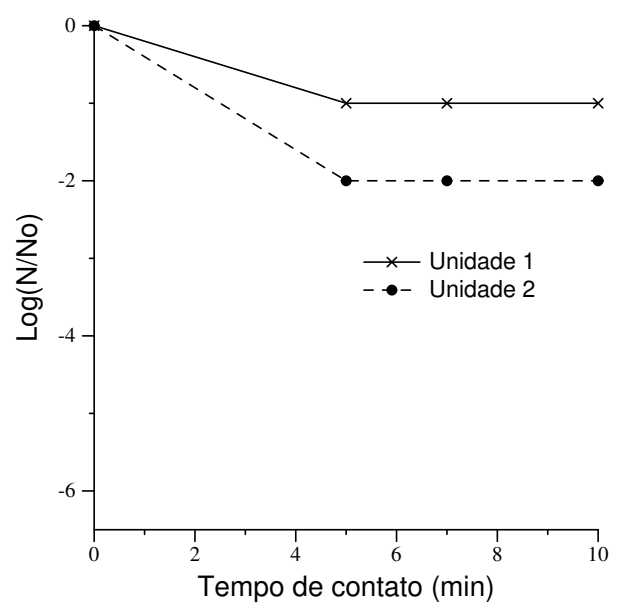

(b) $\mathrm{UV} / \mathrm{O}_{3}$

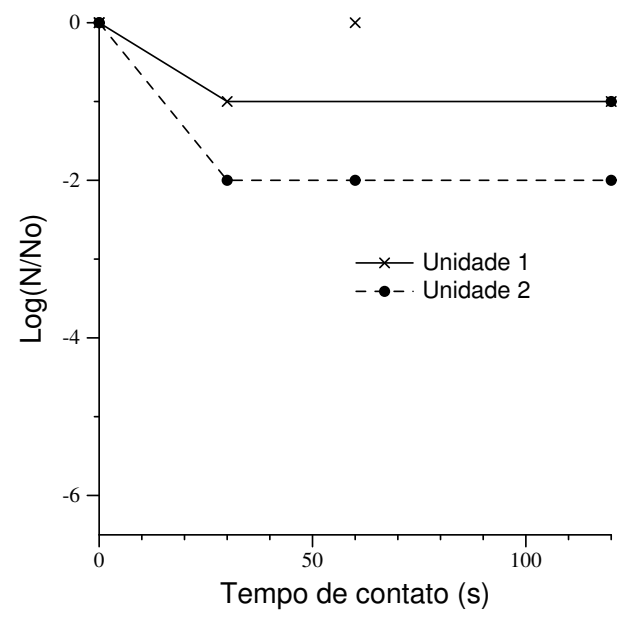

(d) $\mathrm{UV} / \mathrm{UV}$

Figura 5.6: Variação da população de C. perfringens na etapa 2 (ensaio 2).

Unidade 1: Método convencional. Unidade 2: Método alternativo.

$\mathrm{O}_{3}: 5,7$ e 10 minutos. UV: 30, 60 e 120 segundos. 


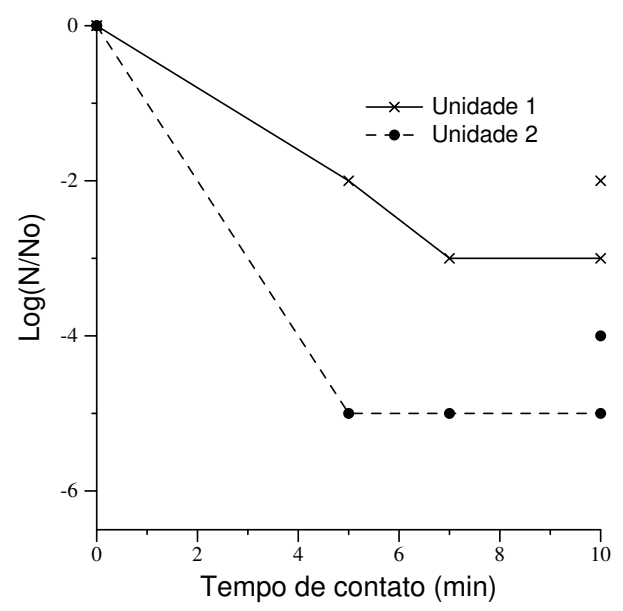

(a) $\mathrm{O}_{3} / \mathrm{O}_{3}$

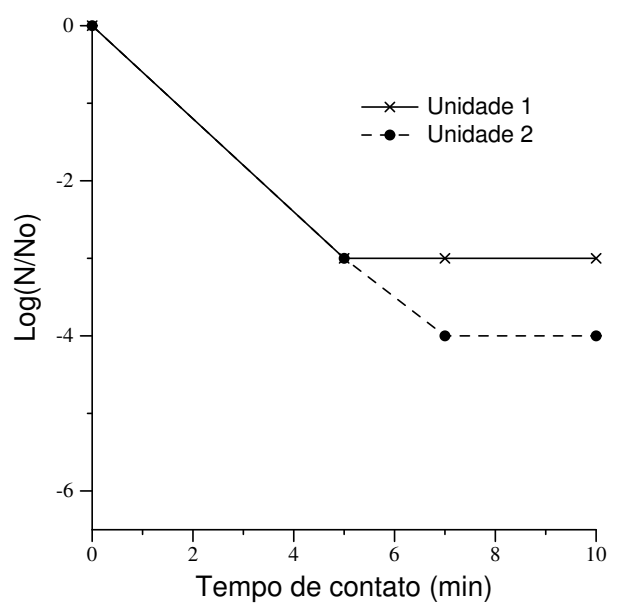

(b) $\mathrm{UV} / \mathrm{O}_{3}$

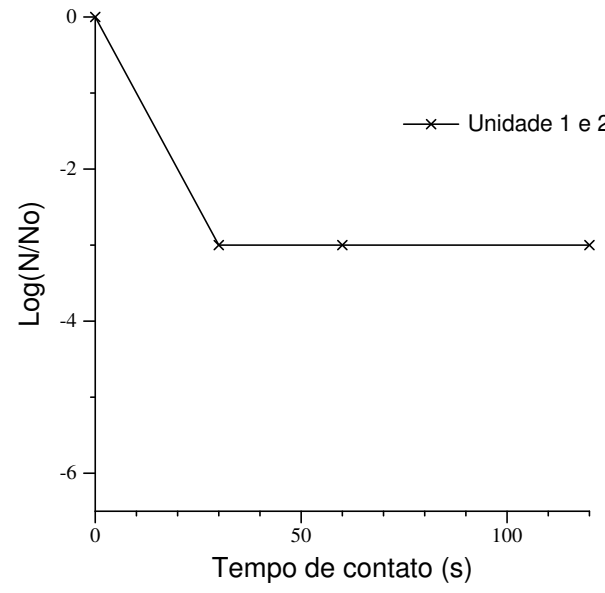

(c) $\mathrm{O}_{3} / \mathrm{UV}$

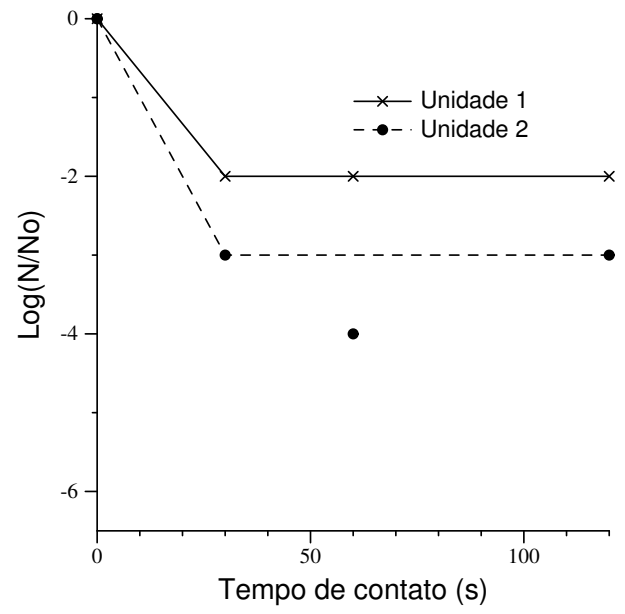

(d) $\mathrm{UV} / \mathrm{UV}$

Figura 5.7: Variação da população de coliformes totais na etapa 2 (ensaio 2). Unidade 1: Método convencional. Unidade 2: Método alternativo. $\mathrm{O}_{3}: 5,7$ e 10 minutos. UV: 30, 60 e 120 segundos. 


\section{Avaliação da Eficiência de Inativação}

A partir das tabelas de número de indivíduos sobreviventes foram elaboradas as relações de eficiência para as unidades convencional e combinada, considerando para os cálculos $\mathrm{N}_{0}=\mathrm{P} 1$ e $\mathrm{N}$ correspondente aos vários tempos de contato analisados. Os resultados obtidos estão indicados nas Tabelas 5.11, 5.12, 5.13 e $5.14^{14}$

Embora os gráficos de $\log \left(\mathrm{N} / \mathrm{N}_{0}\right)$ demonstrem a tendência à diminuição do número de sobreviventes com o tempo, na prática, em termos absolutos a variável tempo de contato não representou grandes acréscimos ao efeito da inativação, como pode ser visualizado nas Tabelas 5.7, 5.8, 5.9 e 5.10, para 5, 7 e 10 minutos com adição de ozônio e 30, 60 e 120 segundos com aplicação de radiação UV.

Para uma mesma seqüência pré-desinfecção/desinfecção, os valores confirmam que praticamente não houve influência da variável tempo de contato, tanto nos ensaios com ozônio quanto na presença de radiação UV.

No primeiro caso, este comportamento pode estar associado à elevada concentração de ozônio na etapa 2, próxima de $30 \mathrm{mg} / \mathrm{L}$, responsável pela inativação quase completa da população de microrganismos presentes, ainda que submetida a curto intervalo de tempo.

Portanto, os primeiros instantes de contato entre o agente de inativação e o microrganismo foram suficientes para se alcançar os altos índices obtidos em todos os casos avaliados. A partir deste contato inicial possivelmente permaneceram ativos apenas os elementos mais resistentes, ou ainda o consumo da dosagem aplicada atingiu valores muito baixo, impedindo o prosseguimento da desinfecção.

Outro aspecto relevante é a influência do agente químico ou físico. A análise dos dados revelou que a eficiência global da desinfecção praticamente não sofreu variações entre as quatro seqüências examinadas. Assim sendo, para as condições investigadas, as combinações $\mathrm{O}_{3} / \mathrm{O}_{3}, \mathrm{O}_{3} / \mathrm{UV}, \mathrm{UV} / \mathrm{O}_{3}$ e $\mathrm{UV} / \mathrm{UV}$ não apresentaram respostas muito diferentes.

\footnotetext{
${ }^{14}$ Ensaios 1 e 3: Tabelas 8.16, 8.17, 8.18, 8.19.
} 
Tabela 5.11: Eficiência de inativação de Escherichia coli (ensaio 2).

\begin{tabular}{|c|c|c|c|c|c|c|c|c|c|c|c|c|c|c|c|c|c|c|}
\hline & \multicolumn{9}{|c|}{ Eficiência (\%) - Unidade 1} & \multicolumn{9}{|c|}{ Eficiência (\%) - Unidade 2} \\
\hline & $\mathrm{P} 4$ & $\mathrm{~T}_{1}:$ & 5 & 7 & 10 & $\mathrm{~T}_{2}$ : & 30 & 60 & 120 & $\mathrm{P} 3$ & $\mathrm{~T}_{1}:$ & 5 & 7 & 10 & $\mathrm{~T}_{2}:$ & 30 & 60 & 120 \\
\hline $\mathrm{O}_{3} / \mathrm{O}_{3}$ & 0 & & 99,99 & 99,9 & 99,9 & & - & - & - & 99,0 & & 100,0 & 99,999 & 99,999 & & - & - & - \\
\hline $\mathrm{UV} / \mathrm{O}_{3}$ & 0 & & 99,0 & 99,9 & 99,9 & & - & - & - & 90,0 & & 100,0 & 100,0 & 100,0 & & - & - & - \\
\hline $\mathrm{O}_{3} / \mathrm{UV}$ & 88,89 & & - & - & - & & 99,22 & 99,95 & 99,75 & 88,89 & & - & - & - & & 100,0 & 100,0 & 100,0 \\
\hline $\mathrm{UV} / \mathrm{UV}$ & 90,0 & & - & - & - & & 99,999 & 99,999 & 99,9 & 99,0 & & - & - & - & & 99,999 & 99,999 & 99,9 \\
\hline
\end{tabular}

$\mathrm{T}_{1}$ : Tempo de contato, $\mathrm{O}_{3}(\mathrm{~min}) . \mathrm{T}_{2}$ : Tempo de contato, UV (s). Unidade 1: Método convencional. Unidade 2: Método alternativo. P3: Efluente após pré-desinfecção seguido de tratamento biológico. P4: Efluente bruto seguido de tratamento biológico.

Tabela 5.12: Eficiência de inativação de colifagos (ensaio 2).

\begin{tabular}{|c|c|c|c|c|c|c|c|c|c|c|c|c|c|c|c|c|c|c|}
\hline & \multicolumn{9}{|c|}{ Eficiência (\%) - Unidade 1} & \multicolumn{9}{|c|}{ Eficiência (\%) - Unidade 2} \\
\hline & $\mathrm{P} 4$ & $\mathrm{~T}_{1}:$ & 5 & 7 & 10 & $\mathrm{~T}_{2}:$ & 30 & 60 & 120 & P3 & $\mathrm{T}_{1}:$ & 5 & 7 & 10 & $\mathrm{~T}_{2}:$ & 30 & 60 & 120 \\
\hline $\mathrm{O}_{3} / \mathrm{O}_{3}$ & 0 & & 99,0 & 99,9 & 99,9 & & - & - & - & 0 & & 99,0 & 99,9 & 99,9 & & - & - & - \\
\hline $\mathrm{UV} / \mathrm{O}_{3}$ & 90,0 & & 90,0 & 90,0 & 90,0 & & - & - & - & 99,9 & & 100,0 & 100,0 & 100,0 & & - & - & - \\
\hline $\mathrm{O}_{3} / \mathrm{UV}$ & 0 & & - & - & - & & 100,0 & 90,0 & 100,0 & 0 & & - & - & - & & 100,0 & 100,0 & 100,0 \\
\hline $\mathrm{UV} / \mathrm{UV}$ & 0 & & - & - & - & & 100,0 & 100,0 & 100,0 & 0 & & - & - & - & & 100,0 & 100,0 & 100,0 \\
\hline
\end{tabular}

$\mathrm{T}_{1}$ : Tempo de contato, $\mathrm{O}_{3}(\mathrm{~min}) . \mathrm{T}_{2}$ : Tempo de contato, UV (s). Unidade 1: Método convencional. Unidade 2: Método alternativo.

P3: Efluente após pré-desinfecção seguido de tratamento biológico. P4: Efluente bruto seguido de tratamento biológico. 
Tabela 5.13: Eficiência de inativação de Clostridium perfringens (ensaio 2).

\begin{tabular}{|c|c|c|c|c|c|c|c|c|c|c|c|c|c|c|c|c|c|c|}
\hline & \multicolumn{9}{|c|}{ Eficiência (\%) - Unidade 1} & \multicolumn{9}{|c|}{ Eficiência (\%) - Unidade 2} \\
\hline & $\mathrm{P} 4$ & $\mathrm{~T}_{1}$ : & 5 & 7 & 10 & $\mathrm{~T}_{2}$ : & 30 & 60 & 120 & P3 & $\mathrm{T}_{1}:$ & 5 & 7 & 10 & $\mathrm{~T}_{2}:$ & 30 & 60 & 120 \\
\hline $\mathrm{O}_{3} / \mathrm{O}_{3}$ & 0 & & 0 & 99,0 & 99,0 & & - & - & - & 0 & & 99,0 & 99,0 & 99,0 & & - & - & - \\
\hline $\mathrm{UV} / \mathrm{O}_{3}$ & 0 & & 90,0 & 90,0 & 90,0 & & - & - & - & 90,0 & & 99,0 & 99,0 & 99,0 & & - & - & - \\
\hline $\mathrm{O}_{3} / \mathrm{UV}$ & 0 & & - & - & - & & 90,0 & 90,0 & 90,0 & 90,0 & & - & - & - & & 90,0 & 99,0 & 99,0 \\
\hline UV/UV & 0 & & - & - & - & & 90,0 & 0 & 90,0 & 90,0 & & - & - & - & & 99,0 & 99,0 & 90,0 \\
\hline
\end{tabular}

$\mathrm{T}_{1}$ : Tempo de contato, $\mathrm{O}_{3}(\mathrm{~min})$. $\mathrm{T}_{2}$ : Tempo de contato, UV (s). Unidade 1: Método convencional. Unidade 2: Método alternativo. P3: Efluente após pré-desinfecção seguido de tratamento biológico. P4: Efluente bruto seguido de tratamento biológico.

Tabela 5.14: Eficiência de inativação de coliformes totais (ensaio 2).

\begin{tabular}{|c|c|c|c|c|c|c|c|c|c|c|c|c|c|c|c|c|c|c|}
\hline & \multicolumn{9}{|c|}{ Eficiência (\%) - Unidade 1} & \multicolumn{9}{|c|}{ Eficiência (\%) - Unidade 2} \\
\hline & $\mathrm{P} 4$ & $\mathrm{~T}_{1}:$ & 5 & 7 & 10 & $\mathrm{~T}_{2}:$ & 30 & 60 & 120 & P3 & $\mathrm{T}_{1}:$ & 5 & 7 & 10 & $\mathrm{~T}_{2}:$ & 30 & 60 & 120 \\
\hline $\mathrm{O}_{3} / \mathrm{O}_{3}$ & 0 & & 99,0 & 99,9 & 99,0 & & - & - & - & 90,0 & & 99,999 & 99,999 & 99,99 & & - & - & - \\
\hline $\mathrm{UV} / \mathrm{O}_{3}$ & 0 & & 99,9 & 99,9 & 99,9 & & - & - & - & 90,0 & & 99,9 & 99,99 & 99,99 & & - & - & - \\
\hline $\mathrm{O}_{3} / \mathrm{UV}$ & 0 & & - & - & - & & 99,9 & 99,9 & 99,9 & 90,0 & & - & - & - & & 99,9 & 99,9 & 99,9 \\
\hline $\mathrm{UV} / \mathrm{UV}$ & 0 & & - & - & - & & 99,0 & 99,9 & 99,9 & 0 & & - & - & - & & 99,9 & 99,99 & 99,9 \\
\hline
\end{tabular}

$\mathrm{T}_{1}$ : Tempo de contato, $\mathrm{O}_{3}(\mathrm{~min})$. $\mathrm{T}_{2}$ : Tempo de contato, UV (s). Unidade 1: Método convencional. Unidade 2: Método alternativo.

P3: Efluente após pré-desinfecção seguido de tratamento biológico. P4: Efluente bruto seguido de tratamento biológico. 
Entretanto, embora procedentes, estas ponderações não contam com embasamento estatístico cuja interpretação porporcionaria resultados mais expressivos. Trabalhos futuros devem ser desenvolvidos neste sentido uma vez que não pertence aos objetivos deste estudo o aprofundamento na análise estatística dos dados experimentais coletados, em virtude do grande número de variáveis e combinações possíveis, impossibilitando, em um relativo curto espaço de tempo sua interpretação.

\subsection{Parte IV: Estudo Comparativo}

Com base nas análises e discussões realizadas nas seções anteriores, foram avaliados os aspectos práticos concernentes a utilização do sistema conjugado aplicado às unidades piloto de ozonização e radiação UV, descritos a seguir.

\section{Aspectos Gerais}

As técnicas de desinfecção investigadas são, em sua essência, fundamentalmente distintas. Enquanto o gás ozônio promove reações oxidativas, a radiação UV, por outro lado, induz a reações fotoquímicas, alterando a natureza energética da ligação química atingida.

Por conseguinte, dependendo do mecanismo de ação empregado (químico ou físico) o agente germicida pode comportar-se de modo diferente frente às mesmas condições experimentais. Variações de $\mathrm{pH}$ e temperatura, por exemplo, podem representar sérias limitações à técnica de ozonização, em oposição à radiação UV, cujo desempenho pouco é influenciado por estes parâmetros.

Desse modo, devido a natureza química da ação do ozônio, o processo de ozonização como um todo pode sofrer maior influência das condições gerais do meio, quando comparado ao emprego dos raios UV. Isto se deve, em grande parte, às relações de equilíbrio químico envolvidas nas reações de oxi-redução, cujo desenvolvimento depende de parâmetros diversos. Portanto, estes fatores 
podem representar limitações à técnica de ozonização pois reduzem a taxa de transferência gás-líquido.

Na prática, entretanto, para as condições investigadas, não foram observadas grandes variações entre as respostas de inativação obtidas nas unidades piloto de ozonização e radiação UV.

\section{Eficiência de Inativação}

Não obstante as limitações associadas aos experimentos desenvolvidos na etapa 1, possivelmente decorrentes de variações na qualidade do efluente bruto e da própria configuração da instalação experimental, a taxa de inativação de Escherichia coli, colifagos, Clostridium perfringens e coliformes totais revelou índices de redução bastante positivos em relação ao sistema convencional.

Considerando as baixas dosagens de ozônio e radiação UV introduzidas na pré-desinfecção e a própria inconstância da qualidade do efluente na entrada da instalação piloto, os resultados alcançados sugerem grande potencialidade de aplicação do método proposto.

Portanto, a viabilidade técnica do método combinado como hipótese inicial deste trabalho foi experimentalmente testada e comprovada. Entretanto, estudos devem ser realizados para avaliar sua aplicabilidade econômica, incluindo projetos para otimizar sua configuração.

\section{Qualidade do Efluente}

Embora as técnicas de ozonização e radiação UV apresentem restrições quanto a concentração relativamente elevada de sólidos em suspensão e dissolvido, na prática os resultados obtidos revelaram pouco efeito destes componentes na eficiência de inativação, para as condições analisadas. 


\section{Configuração do Sistema}

Dentre as questões de ordem técnica relativas ao sistema de pré-desinfecção especial destaque está voltado à configuração da câmara de reação.

A unidade de ozonização utilizada na etapa 1 apresentou desempenho abaixo do esperado, exigindo estudos aprofundados com vistas ao desenvolvimento de mecanismos mais eficientes de contato gás-líquido. Do mesmo modo, o rendimento do reator fotoquímico pode ter sido afetado pela fixação submersa da lâmpada, comprometendo sua capacidade de irradiação. 


\section{Capítulo 6}

\section{Conclusões}

Com base nas observações relatadas no capítulo anterior, pôde-se concluir que a utilização de sistemas combinados pré-desinfecção/desinfecção apresenta potencial efetivo de aplicação em unidades reais de tratamento.

Impedimentos práticos comumente observados em instalações mantidas sob regime contínuo de operação não representaram dificuldades adicionais ao desempenho do método.

Neste contexto, a viabilidade técnica de etapas conjugadas destinadas à desinfecção de esgoto sanitário confirma, portanto, a hipótese originalmente sugerida como tema de pesquisa para este trabalho, embora estudos futuros devam ser realizados para avaliar sua aplicabilidade econômica.

Diante das considerações apresentadas a cerca do método alternativo proposto, alguns aspectos merecem especial destaque. São eles:

- Dosagens relativamente baixas de ozônio ou radiação UV para atingir os níveis de inativação indicados.

- Pouca influência da variação da qualidade do efluente bruto nos resultados obtidos.

- Índices satisfatórios de inativação mesmo sob o efeito da concentração de sólidos suspensos totais e voláteis.

• Eficiência de desinfecção mesmo diante de problemas operacionais enfrentados 
nas unidades piloto de pré-desinfecção.

- Capacidade de inativação de espécies mais resistentes como Clostridium perfringens.

- Tempo de contato bastante curto para se obter os resultados apresentados. 


\section{Capítulo 7}

\section{Considerações Finais}

Embora esforços tenham sido direcionados à obtenção de máxima eficiência na operação das unidades experimentais utilizadas, surgiram ao longo desta pesquisa informações relevantes, as quais podem representar sugestões e possibilidades para futuros trabalhos voltados ao desenvolvimento do tema tratado.

\section{Sistemas Combinados}

- Aprofundar o estudo a cerca das seqüências $\mathrm{O}_{3} / \mathrm{O}_{3}, \mathrm{O}_{3} / \mathrm{UV}, \mathrm{UV} / \mathrm{O}_{3}$ e UV/UV, tratadas individualmente.

- Pesquisar o efeito da aplicação de dosagens mais baixas na segunda etapa de desinfecção.

- Otimizar a variável tempo de contato de modo a atingir níveis equivalentes de desinfecção com custo operacional reduzido.

- Empregar ferramenta estatística para análise dos dados coletados.

- Promover o desenvolvimento de configurações mais eficientes para o contato na pré-desinfecção para se obter melhor taxa de inativação.

- Investigar o efeito de sistemas combinados na potencialidade mutagênica de indicadores de contaminação.

- Desenvolver metodologia adequada para o acompanhamento da concentração de carbono orgânico total nas amostras. 
- Avaliar e comparar a formação de subprodutos nos sistemas convencional e alternativo. 
Capítulo 8

Anexo A 
Tabela 8.1: Caracterização das amostras coletadas no ensaio 1 para a seqüência $O_{3} / O_{3}$.

\begin{tabular}{|c|c|c|c|c|c|c|c|c|c|c|c|c|}
\hline & \multicolumn{5}{|c|}{ Etapa 1 - Pré-desinfecção } & \multicolumn{7}{|c|}{ Etapa 2 - Desinfecção } \\
\hline & \multirow[b]{2}{*}{ A: } & \multicolumn{4}{|c|}{ Unidade 1 e 2} & \multirow[b]{2}{*}{$\mathrm{T}:$} & \multicolumn{3}{|c|}{ Unidade (1) } & \multicolumn{3}{|c|}{ Unidade 2} \\
\hline & & $\mathrm{P} 1$ & $\mathrm{P} 2-\mathrm{O}_{3}$ & $\mathrm{P} 3-\mathrm{O}_{3}$ & $\mathrm{P} 4$ & & 5 & 7 & 10 & 5 & 7 & 10 \\
\hline Alcalinidade $(m g / L)$ & & 149 & 143 & - & 28 & & 77 & 83 & 66 & - & - & 28 \\
\hline $\mathrm{DQO}(m g / L)$ & & 82 & 103 & 126 & 51 & & 48 & 48 & 40 & 36 & 39 & 33 \\
\hline Dose efetiva $(m g / L)$ & & - & 1 & - & - & & 32 & 32 & 36 & 30 & 31 & 29 \\
\hline $\mathrm{pH}$ & & 6,7 & 6,0 & 3,0 & 5,5 & & 6,2 & 6,3 & 6,4 & 3,7 & 3,6 & 5,5 \\
\hline $\operatorname{SST}(m g / L)$ & & 65 & 63 & 90 & 24 & & 84 & 11 & 81 & 104 & 44 & 67 \\
\hline $\operatorname{SSV}(m g / L)$ & & 61 & 56 & 73 & 13 & & 58 & 5 & 60 & 70 & 40 & 46 \\
\hline Colifagos $(U F P / 100 m l)$ & & $45.10^{2}$ & $72.10^{2}$ & $15.10^{1}$ & $12.10^{2}$ & & 0 & 20 & 15 & 0 & 5 & 0 \\
\hline C. total $(U F C / 100 m l)$ & & $39.10^{5}$ & $18.10^{5}$ & $28.10^{5}$ & $42.10^{5}$ & & 206 & 243 & 238 & 101 & 139 & 150 \\
\hline C. perfringens $(N M P / 100 m l)$ & & $7.10^{4}$ & $8.10^{3}$ & $2.10^{3}$ & $3.10^{4}$ & & 20 & 1700 & 1300 & 120 & 270 & 230 \\
\hline E. coli $(U F C / 100 m l)$ & & $5.10^{5}$ & $6.10^{5}$ & $4.10^{4}$ & $3.10^{4}$ & & 5 & 13 & 46 & 0 & 0 & 0 \\
\hline
\end{tabular}

T: Tempo de contato (min). Unidade 1: Método convencional. Unidade 2: Método alternativo.

P1: Efluente bruto. P2-o 3 : Efluente bruto após ozonização. P3-o 3 : Efluente ozonizado seguido de tratamento biológico. P2-uv: Efluente após irradiação com UV.

P3-uv: Efluente após irradiação com UV seguido de tratamento biológico. P4: Efluente bruto seguido de tratamento biológico. 
Tabela 8.2: Caracterização das amostras coletadas no ensaio 1 para a seqüência $O_{3} / U V$.

\begin{tabular}{|c|c|c|c|c|c|c|c|c|c|c|c|c|}
\hline & \multicolumn{5}{|c|}{ Etapa 1 - Pré-desinfeç̧ão } & \multicolumn{7}{|c|}{ Etapa 2 - Desinfecção } \\
\hline & A: & \multicolumn{4}{|c|}{ Unidade 1 e 2} & $\mathrm{~T}:$ & \multicolumn{3}{|c|}{ Unidade 1} & \multicolumn{3}{|c|}{ Unidade 2} \\
\hline Alcalinidade $(m g / L)$ & & 267 & 229 & - & 172 & & 143 & 134 & 134 & - & - & - \\
\hline Dose efetiva $^{a} b$ & & - & 1 & - & - & & 66 & 138 & 288 & 72 & 150 & 324 \\
\hline $\mathrm{pH}$ & & 7,1 & 6,7 & 3,5 & 7,4 & & 3,6 & 3,6 & 3,7 & 7,5 & 7,2 & 7,3 \\
\hline $\operatorname{SST}(m g / L)$ & & 149 & 119 & 82 & 91 & & 22 & 23 & 106 & 107 & 53 & 87 \\
\hline $\operatorname{SSV}(m g / L)$ & & 21 & 15 & 56 & 14 & & 11 & 13 & 28 & 57 & 48 & 41 \\
\hline C. perfringens $(N M P / 100 m l)$ & & 800 & 800 & 800 & 800 & & 40 & 60 & 40 & 20 & 40 & 40 \\
\hline E. $\operatorname{coli}(U F C / 100 m l)$ & & $50.10^{4}$ & $64.10^{4}$ & $10.10^{4}$ & $16.10^{4}$ & & $6.10^{2}$ & $3.10^{2}$ & $40.10^{2}$ & 0 & 0 & $1.10^{2}$ \\
\hline
\end{tabular}

[a] Etapa 1: mg/L. [b] Etapa 2: $\mathrm{mW} \cdot \mathrm{s} / \mathrm{cm}^{2}$.

T: Tempo de contato (s). Unidade 1: Método convencional. Unidade 2: Método alternativo.

P1: Efluente bruto. P2-o $:$ Efluente bruto após ozonização. P3-o3: Efluente ozonizado seguido de tratamento biológico. P2-uv: Efluente após irradiação com UV.

P3-uv: Efluente após irradiação com UV seguido de tratamento biológico. P4: Efluente bruto seguido de tratamento biológico. 
Tabela 8.3: Caracterização das amostras coletadas no ensaio 1 para a seqüência $U V / O_{3}$.

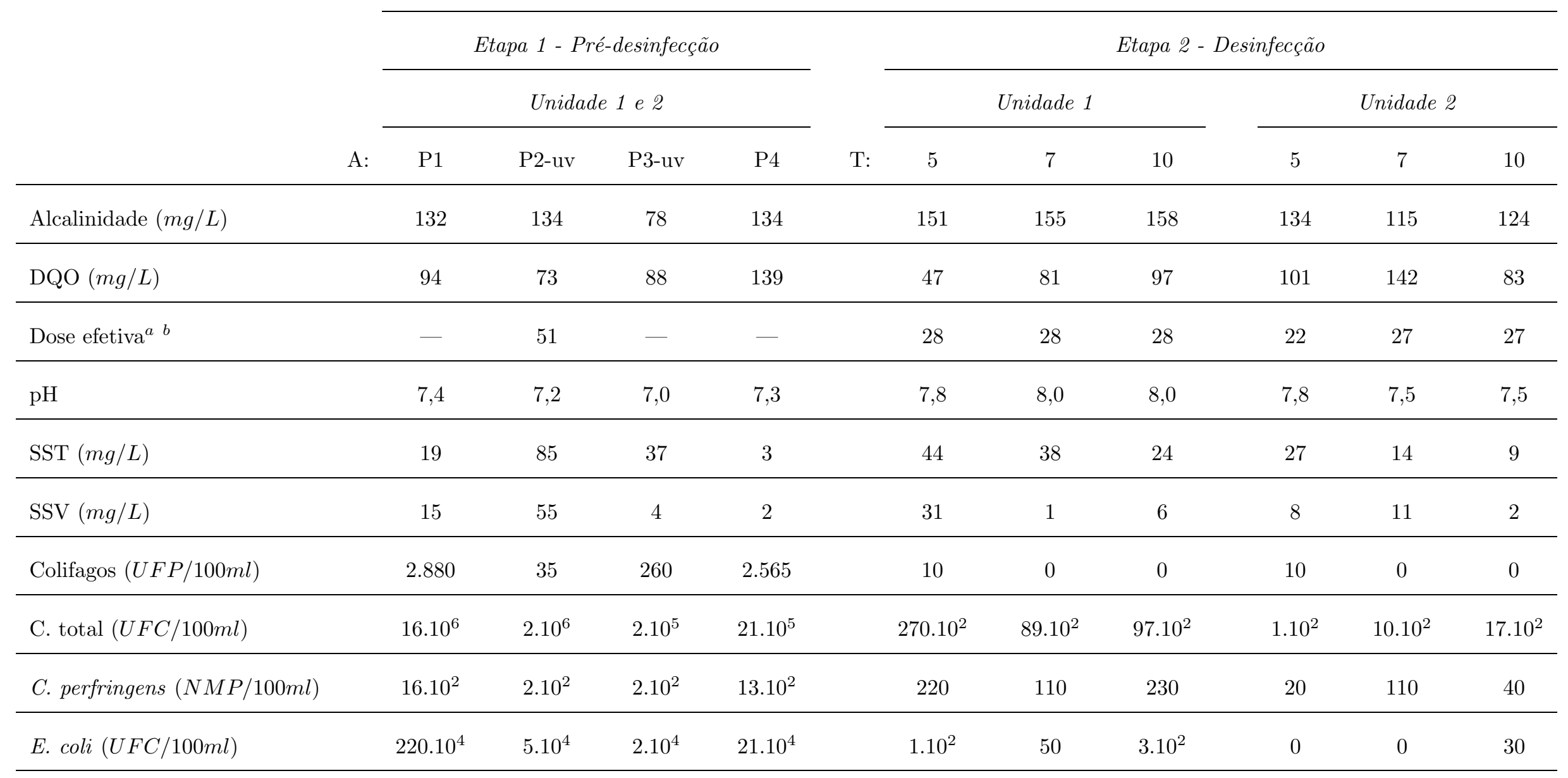

[a] Etapa 1: $\mathrm{mW} . \mathrm{s} / \mathrm{cm}^{2}$. [b] Etapa 2: $\mathrm{mg} / \mathrm{L}$.

T: Tempo de contato (min). Unidade 1: Método convencional. Unidade 2: Método alternativo.

P1: Efluente bruto. P2-o3: Efluente bruto após ozonização. P3-o3: Efluente ozonizado seguido de tratamento biológico. P2-uv: Efluente após irradiação com UV.

P3-uv: Efluente após irradiação com UV seguido de tratamento biológico. P4: Efluente bruto seguido de tratamento biológico. 
Tabela 8.4: Caracterização das amostras coletadas no ensaio 1 para a seqüência $U V / U V$.

\begin{tabular}{|c|c|c|c|c|c|c|c|c|c|c|c|c|}
\hline & \multicolumn{5}{|c|}{ Etapa 1 - Pré-desinfecção } & \multicolumn{7}{|c|}{ Etapa 2 - Desinfecção } \\
\hline & \multirow[b]{2}{*}{ A: } & \multicolumn{4}{|c|}{ Unidade 1 e 2} & \multirow[b]{2}{*}{$\mathrm{T}:$} & \multicolumn{3}{|c|}{ Unidade 1} & \multicolumn{3}{|c|}{ Unidade 2} \\
\hline & & $\mathrm{P} 1$ & P2-uv & P3-uv & $\mathrm{P} 4$ & & 30 & 60 & 120 & 30 & 60 & 120 \\
\hline Alcalinidade $(m g / L)$ & & 137 & 151 & 40 & 42 & & 36 & 38 & 34 & 44 & 55 & 51 \\
\hline $\operatorname{DQO}(m g / L)$ & & 117 & 110 & 76 & 85 & & 162 & 158 & 163 & 98 & 100 & 146 \\
\hline Dose efetiva $\left(m W . s / \mathrm{cm}^{2}\right)$ & & - & 51 & - & - & & 60 & 114 & 228 & 54 & 108 & 216 \\
\hline $\mathrm{pH}$ & & 6,8 & 6,2 & 5,6 & 6,4 & & 6,8 & 6,6 & 6,6 & 6,3 & 6,2 & 6,5 \\
\hline $\operatorname{SST}(m g / L)$ & & 14 & 73 & 81 & 87 & & 118 & 73 & 135 & 83 & 70 & 5 \\
\hline $\operatorname{SSV}(m g / L)$ & & 7 & 30 & 27 & 33 & & 70 & 38 & 70 & 31 & 11 & 4 \\
\hline Colifagos $(U F P / 100 m l)$ & & $81.10^{2}$ & $7.10^{2}$ & $1.10^{2}$ & $76.10^{2}$ & & 0 & 0 & 0 & 0 & 0 & 0 \\
\hline C. total $(U F C / 100 m l)$ & & $1.10^{6}$ & $23.10^{5}$ & $42.10^{5}$ & $1.10^{6}$ & & $2.10^{4}$ & $60.10^{2}$ & $97.10^{2}$ & $1.10^{2}$ & $1.10^{2}$ & $10.10^{2}$ \\
\hline C. perfringens $(N M P / 100 m l)$ & & $11.10^{3}$ & $8.10^{3}$ & $1.10^{2}$ & $17.10^{3}$ & & $14.10^{2}$ & $17.10^{2}$ & $1.10^{2}$ & 20 & 0 & 0 \\
\hline E. $\operatorname{coli}(U F C / 100 m l)$ & & $12.10^{5}$ & $56.10^{4}$ & $2.10^{4}$ & $54.10^{4}$ & & 190 & 70 & 100 & 20 & 10 & 0 \\
\hline
\end{tabular}

T: Tempo de contato (s). Unidade 1: Método convencional. Unidade 2: Método alternativo.

P1: Efluente bruto. P2-o 3 : Efluente bruto após ozonização. P3-o 3 : Efluente ozonizado seguido de tratamento biológico. P2-uv: Efluente após irradiação com UV.

P3-uv: Efluente após irradiação com UV seguido de tratamento biológico. P4: Efluente bruto seguido de tratamento biológico. 
Tabela 8.5: Caracterização das amostras coletadas no ensaio 2 para a seqüência $O_{3} / O_{3}$.

\begin{tabular}{|c|c|c|c|c|c|c|c|c|c|c|c|c|}
\hline & \multicolumn{5}{|c|}{ Etapa 1 - Pré-desinfeç̧ão } & \multicolumn{7}{|c|}{ Etapa 2 - Desinfecção } \\
\hline & \multirow[b]{2}{*}{ A: } & \multicolumn{4}{|c|}{ Unidade 1 e 2} & \multirow[b]{2}{*}{$\mathrm{T}:$} & \multicolumn{3}{|c|}{ Unidade 1} & \multicolumn{3}{|c|}{ Unidade 2} \\
\hline & & $\mathrm{P} 1$ & $\mathrm{P} 2-\mathrm{O}_{3}$ & $\mathrm{P} 3-\mathrm{O}_{3}$ & $\mathrm{P} 4$ & & 5 & 7 & 10 & 5 & 7 & 10 \\
\hline Alcalinidade $(m g / L)$ & & 85 & 62 & 13 & 10 & & 259 & 250 & 241 & 16 & 24 & 31 \\
\hline $\mathrm{DQO}(m g / L)$ & & 36 & 59 & 28 & 96 & & 61 & 56 & 57 & 10 & 27 & 45 \\
\hline Dose efetiva $(m g / L)$ & & - & 1 & - & - & & 26 & 29 & 29 & 32 & 30 & 34 \\
\hline $\mathrm{pH}$ & & 7,5 & 7,2 & 4,9 & 4,8 & & 7,1 & 7,1 & 7,0 & 5,4 & 5,8 & 6,2 \\
\hline $\operatorname{SST}(m g / L)$ & & 67 & 49 & 70 & 63 & & 77 & 59 & 54 & 52 & 80 & 76 \\
\hline $\operatorname{SSV}(m g / L)$ & & 28 & 19 & 9 & 20 & & 27 & 15 & 23 & 12 & 21 & 7 \\
\hline Colifagos $(U F P / 100 m l)$ & & $8.10^{5}$ & $7.10^{5}$ & $2.10^{5}$ & $7.10^{5}$ & & 2015 & 1675 & 1365 & 1165 & 102 & 196 \\
\hline C. total $(U F C / 100 m l)$ & & $12.10^{5}$ & $3.10^{5}$ & $3.10^{5}$ & $1.10^{6}$ & & $1.10^{4}$ & $1.10^{3}$ & $1.10^{4}$ & 31 & 32 & 102 \\
\hline C. perfringens $(N M P / 100 m l)$ & & $5.10^{3}$ & $3.10^{3}$ & $2.10^{3}$ & $4.10^{3}$ & & 1.300 & 40 & 90 & 40 & 70 & 70 \\
\hline E. coli $(U F C / 100 m l)$ & & $12.10^{4}$ & $6.10^{4}$ & $1.10^{3}$ & $1.10^{5}$ & & 20 & 130 & 140 & 0 & 1 & 3 \\
\hline
\end{tabular}

T: Tempo de contato (min). Unidade 1: Método convencional. Unidade 2: Método alternativo.

P1: Efluente bruto. P2-o 3 : Efluente bruto após ozonização. P3-o 3 : Efluente ozonizado seguido de tratamento biológico. P2-uv: Efluente após irradiação com UV.

P3-uv: Efluente após irradiação com UV seguido de tratamento biológico. P4: Efluente bruto seguido de tratamento biológico. 
Tabela 8.6: Caracterização das amostras coletadas no ensaio 2 para a seqüência $O_{3} / U V$.

\begin{tabular}{|c|c|c|c|c|c|c|c|c|c|c|c|c|}
\hline & \multicolumn{5}{|c|}{ Etapa 1 - Pré-desinfecção } & \multicolumn{7}{|c|}{ Etapa 2 - Desinfecção } \\
\hline & \multirow[b]{2}{*}{ A: } & \multicolumn{4}{|c|}{ Unidade 1 e 2} & \multirow[b]{2}{*}{$\mathrm{T}:$} & \multicolumn{3}{|c|}{ Unidade 1} & \multicolumn{3}{|c|}{ Unidade 2} \\
\hline & & P1 & $\mathrm{P} 2-\mathrm{O}_{3}$ & $\mathrm{P} 3-\mathrm{O}_{3}$ & $\mathrm{P} 4$ & & 30 & 60 & 120 & 30 & 60 & 120 \\
\hline Alcalinidade $(m g / L)$ & & 229 & 231 & - & - & & 168 & 162 & 155 & - & - & - \\
\hline $\mathrm{DQO}(m g / L)$ & & 47 & 89 & 30 & 55 & & 49 & 82 & 49 & 32 & 11 & 40 \\
\hline Dose efetiva $^{a b}$ & & - & 1 & - & - & & 63 & 138 & 264 & 78 & 198 & 348 \\
\hline $\mathrm{pH}$ & & 6,7 & 7,2 & 3,5 & 3,6 & & 7,3 & 7,2 & 7,3 & 3,5 & 3,6 & 3,5 \\
\hline $\operatorname{SST}(m g / L)$ & & 17 & 28 & 18 & 20 & & 19 & 33 & 41 & 37 & 16 & 25 \\
\hline $\operatorname{SSV}(m g / L)$ & & 8 & 1 & 15 & 9 & & 13 & 8 & 29 & 18 & 13 & 11 \\
\hline Colifagos $(U F P / 100 m l)$ & & 750 & 700 & 300 & 700 & & 0 & 10 & 0 & 0 & 0 & 0 \\
\hline C. total $(U F C / 100 m l)$ & & $31.10^{5}$ & $62.10^{5}$ & $8.10^{5}$ & $41.10^{5}$ & & $8.10^{3}$ & $2.10^{3}$ & $3.10^{3}$ & $3.10^{3}$ & $3.10^{3}$ & $4.10^{3}$ \\
\hline C. perfringens $(\mathrm{NMP} / 100 \mathrm{ml})$ & & $11.10^{2}$ & $14.10^{2}$ & $8.10^{2}$ & $11.10^{2}$ & & 300 & 500 & 500 & 230 & 40 & 70 \\
\hline E. coli $(U F C / 100 m l)$ & & $32.10^{4}$ & $36.10^{4}$ & $4.10^{4}$ & $4.10^{4}$ & & 310 & 20 & 100 & 0 & 0 & 0 \\
\hline
\end{tabular}

[a] Etapa 1: mg/L. [b] Etapa 2: $\mathrm{mW} . \mathrm{s} / \mathrm{cm}^{2}$.

T: Tempo de contato (s). Unidade 1: Método convencional. Unidade 2: Método alternativo.

P1: Efluente bruto. P2-o 3 : Efluente bruto após ozonização. P3-o 3: Efluente ozonizado seguido de tratamento biológico. P2-uv: Efluente após irradiação com UV.

P3-uv: Efluente após irradiação com UV seguido de tratamento biológico. P4: Efluente bruto seguido de tratamento biológico. 
Tabela 8.7: Caracterização das amostras coletadas no ensaio 2 para a seqüência $U V / O_{3}$.

\begin{tabular}{|c|c|c|c|c|c|c|c|c|c|c|c|c|}
\hline & \multicolumn{5}{|c|}{ Etapa 1 - Pré-desinfecção } & \multicolumn{7}{|c|}{ Etapa 2 - Desinfecção } \\
\hline & \multirow[b]{2}{*}{ A: } & \multicolumn{4}{|c|}{ Unidade 1 e 2} & \multirow[b]{2}{*}{$\mathrm{T}:$} & \multicolumn{3}{|c|}{ Unidade 1} & \multicolumn{3}{|c|}{ Unidade 2} \\
\hline & & $\mathrm{P} 1$ & $\mathrm{P} 2-\mathrm{uv}$ & P3-uv & $\mathrm{P} 4$ & & 5 & 7 & 10 & 5 & 7 & 10 \\
\hline Alcalinidade $(m g / L)$ & & 181 & 183 & 30 & 51 & & 34 & 42 & 44 & 25 & 23 & 25 \\
\hline $\mathrm{DQO}(m g / L)$ & & 101 & 71 & 32 & 52 & & 52 & 34 & 80 & 27 & 24 & 40 \\
\hline Dose efetiva $^{a} b$ & & - & 51 & - & - & & 24 & 25 & 28 & 24 & 30 & 29 \\
\hline $\mathrm{pH}$ & & 7,3 & 7,1 & 6,0 & 6,5 & & 6,7 & 6,8 & 6,7 & 6,2 & 6,4 & 6,2 \\
\hline $\operatorname{SST}(m g / L)$ & & 96 & 33 & 72 & 101 & & 81 & 43 & 38 & 61 & 84 & 35 \\
\hline $\operatorname{SSV}(m g / L)$ & & 10 & 23 & 3 & 23 & & 16 & 32 & 19 & 9 & 11 & 20 \\
\hline Colifagos $(U F P / 100 m l)$ & & $52.10^{2}$ & $1.10^{2}$ & 0 & $11.10^{2}$ & & 350 & 500 & 500 & 0 & 0 & 0 \\
\hline C. total $(U F C / 100 m l)$ & & $10.10^{6}$ & $10.10^{6}$ & $1.10^{6}$ & $10.10^{6}$ & & $31.10^{3}$ & $20.10^{3}$ & $15.10^{3}$ & $33.10^{3}$ & $1.10^{3}$ & $14.10^{2}$ \\
\hline C. perfringens $(N M P / 100 m l)$ & & $27.10^{2}$ & $17.10^{2}$ & $9.10^{2}$ & $17.10^{2}$ & & 330 & 500 & 340 & 60 & 40 & 90 \\
\hline E. $\operatorname{coli}(U F C / 100 m l)$ & & $83.10^{4}$ & $3.10^{4}$ & $9.10^{4}$ & $17.10^{4}$ & & $14.10^{2}$ & $7.10^{2}$ & $9.10^{2}$ & 0 & 0 & 0 \\
\hline
\end{tabular}

[a] Etapa 1: $\mathrm{mW} \cdot \mathrm{s} / \mathrm{cm}^{2}$. [b] Etapa 2: mg/L.

T: Tempo de contato (min). Unidade 1: Método convencional. Unidade 2: Método alternativo.

P1: Efluente bruto. P2-o 3 : Efluente bruto após ozonização. P3-o 3: Efluente ozonizado seguido de tratamento biológico. P2-uv: Efluente após irradiação com UV.

P3-uv: Efluente após irradiação com UV seguido de tratamento biológico. P4: Efluente bruto seguido de tratamento biológico. 
Tabela 8.8: Caracterização das amostras coletadas no ensaio 2 para a seqüência $U V / U V$.

\begin{tabular}{|c|c|c|c|c|c|c|c|c|c|c|c|c|}
\hline & \multicolumn{5}{|c|}{ Etapa 1 - Pré-desinfecção } & \multicolumn{7}{|c|}{ Etapa 2 - Desinfecção } \\
\hline & \multirow[b]{2}{*}{ A: } & \multicolumn{4}{|c|}{ Unidade 1 e 2} & \multirow[b]{2}{*}{$\mathrm{T}:$} & \multicolumn{3}{|c|}{ Unidade 1} & \multicolumn{3}{|c|}{ Unidade 2} \\
\hline & & $\mathrm{P} 1$ & P2-uv & P3-uv & $\mathrm{P} 4$ & & 30 & 60 & 120 & 30 & 60 & 120 \\
\hline Alcalinidade $(m g / L)$ & & 90 & 112 & 75 & 57 & & 38 & 42 & 60 & 55 & 31 & 72 \\
\hline DQO $(m g / L)$ & & 97 & 101 & 84 & 70 & & 112 & 128 & 100 & 92 & 85 & 49 \\
\hline Dose efetiva $\left(m W . s / \mathrm{cm}^{2}\right)$ & & - & 51 & - & - & & 61 & 116 & 239 & 55 & 115 & 227 \\
\hline $\mathrm{pH}$ & & 6,0 & 6,5 & 6,4 & 6,0 & & 6,8 & 6,8 & 6,7 & 6,6 & 6,9 & 6,4 \\
\hline $\operatorname{SST}(m g / L)$ & & 60 & 63 & 91 & 47 & & 99 & 70 & 68 & 88 & 71 & 23 \\
\hline $\operatorname{SSV}(m g / L)$ & & 30 & 24 & 18 & 29 & & 71 & 38 & 29 & 33 & 10 & 8 \\
\hline Colifagos $(U F P / 100 m l)$ & & $25.10^{2}$ & $21.10^{2}$ & $15.10^{2}$ & $23.10^{2}$ & & 0 & 0 & 0 & 0 & 0 & 0 \\
\hline C. total $(U F C / 100 m l)$ & & $8.10^{6}$ & $11.10^{5}$ & $10.10^{5}$ & $1.10^{6}$ & & $31.10^{3}$ & $26.10^{3}$ & $1.10^{4}$ & $8.10^{2}$ & $1.10^{2}$ & $10.10^{2}$ \\
\hline C. perfringens $(N M P / 100 m l)$ & & $10.10^{2}$ & $8.10^{3}$ & $1.10^{2}$ & $10.10^{2}$ & & $2.10^{2}$ & $17.10^{2}$ & $1.10^{2}$ & 20 & 10 & $10^{2}$ \\
\hline E. $\operatorname{coli}(U F C / 100 m l)$ & & $39.10^{5}$ & $13.10^{4}$ & $2.10^{4}$ & $54.10^{4}$ & & $91.10^{1}$ & 103 & $70.10^{2}$ & 20 & 20 & $10.10^{1}$ \\
\hline
\end{tabular}

T: Tempo de contato (s). Unidade 1: Método convencional. Unidade 2: Método alternativo.

P1: Efluente bruto. P2-o 3 : Efluente bruto após ozonização. P3-o 3 : Efluente ozonizado seguido de tratamento biológico. P2-uv: Efluente após irradiação com UV.

P3-uv: Efluente após irradiação com UV seguido de tratamento biológico. P4: Efluente bruto seguido de tratamento biológico. 
Tabela 8.9: Caracterização das amostras coletadas no ensaio 3 para a seqüência $O_{3} / O_{3}$.

\begin{tabular}{|c|c|c|c|c|c|c|c|c|c|c|c|c|}
\hline & \multicolumn{5}{|c|}{ Etapa 1 - Pré-desinfecção } & \multicolumn{7}{|c|}{ Etapa 2 - Desinfecção } \\
\hline & \multirow[b]{2}{*}{ A: } & \multicolumn{4}{|c|}{ Unidade 1 e 2} & \multirow[b]{2}{*}{$\mathrm{T}:$} & \multicolumn{3}{|c|}{ Unidade 1} & \multicolumn{3}{|c|}{ Unidade 2} \\
\hline & & P1 & $\mathrm{P} 2-\mathrm{O}_{3}$ & $\mathrm{P} 3-\mathrm{O}_{3}$ & $\mathrm{P} 4$ & & 5 & 7 & 10 & 5 & 7 & 10 \\
\hline Alcalinidade $(m g / L)$ & & 226 & 186 & - & 168 & & 160 & 156 & 169 & - & - & - \\
\hline $\mathrm{DQO}(m g / L)$ & & 46 & 29 & 8 & 24 & & 60 & 28 & 44 & 6 & 12 & 21 \\
\hline Dose efetiva $(m g / L)$ & & - & 1 & - & - & & 25 & 25 & 29 & 30 & 24 & 21 \\
\hline $\mathrm{pH}$ & & 7,0 & 6,5 & 2,7 & 7,0 & & 7,1 & 7,0 & 7,1 & 2,8 & 2,7 & 2,7 \\
\hline $\operatorname{SST}(m g / L)$ & & 38 & 21 & 21 & 40 & & 7 & 21 & 27 & 6 & 3 & 37 \\
\hline $\operatorname{SSV}(m g / L)$ & & 5 & 11 & 11 & 3 & & 3 & 3 & 7 & 1 & 5 & 6 \\
\hline Colifagos $(U F P / 100 m l)$ & & $32.10^{2}$ & $29.10^{2}$ & $2.10^{2}$ & $39.10^{2}$ & & 10 & 15 & 29 & 25 & 0 & 0 \\
\hline C. total $(U F C / 100 m l)$ & & $8.10^{5}$ & $2.10^{5}$ & $10^{5}$ & $2.10^{5}$ & & 880 & 910 & 1180 & 120 & 40 & 3 \\
\hline C. perfringens $(N M P / 100 m l)$ & & $15.10^{2}$ & $25.10^{2}$ & $11.10^{2}$ & $25.10^{2}$ & & 115 & 150 & 65 & 20 & 40 & 10 \\
\hline E. coli $(U F C / 100 m l)$ & & $2.10^{5}$ & $5.10^{5}$ & $98.10^{3}$ & $10^{4}$ & & 12 & 16 & 0 & 0 & 4 & 0 \\
\hline
\end{tabular}

T: Tempo de contato (min). Unidade 1: Método convencional. Unidade 2: Método alternativo.

P1: Efluente bruto. P2-o 3 : Efluente bruto após ozonização. P3-o 3 : Efluente ozonizado seguido de tratamento biológico. P2-uv: Efluente após irradiação com UV.

P3-uv: Efluente após irradiação com UV seguido de tratamento biológico. P4: Efluente bruto seguido de tratamento biológico. 
Tabela 8.10: Caracterização das amostras coletadas no ensaio 3 para a seqüência $O_{3} / U V$.

\begin{tabular}{|c|c|c|c|c|c|c|c|c|c|c|c|c|}
\hline & \multicolumn{5}{|c|}{ Etapa 1 - Pré-desinfecção } & \multicolumn{7}{|c|}{ Etapa 2 - Desinfecção } \\
\hline & \multirow[b]{2}{*}{ A: } & \multicolumn{4}{|c|}{ Unidade 1 e 2} & \multirow[b]{2}{*}{$\mathrm{T}:$} & \multicolumn{3}{|c|}{ Unidade 1} & \multicolumn{3}{|c|}{ Unidade 2} \\
\hline & & $\mathrm{P} 1$ & $\mathrm{P} 2-\mathrm{O}_{3}$ & $\mathrm{P} 3-\mathrm{O}_{3}$ & $\mathrm{P} 4$ & & 30 & 60 & 120 & 30 & 60 & 120 \\
\hline Alcalinidade $(m g / L)$ & & 155 & 193 & 76 & 200 & & 179 & 200 & 191 & 78 & 80 & 76 \\
\hline $\operatorname{DQO}(m g / L)$ & & 46 & 32 & 25 & 43 & & 59 & 60 & 57 & 37 & 27 & 40 \\
\hline Dose efetiva $^{a b}$ & & - & 1 & - & - & & 66 & 108 & 216 & 54 & 132 & 264 \\
\hline $\mathrm{pH}$ & & 7,1 & 6,9 & 6,2 & 7,0 & & 7,1 & 7,3 & 7,3 & 6,3 & 6,4 & 6,4 \\
\hline $\operatorname{SST}(m g / L)$ & & 31 & 39 & 9 & 44 & & 14 & 27 & 21 & 19 & 28 & 9 \\
\hline $\operatorname{SSV}(m g / L)$ & & 15 & 10 & 5 & 32 & & 6 & 11 & 8 & 1 & 4 & 8 \\
\hline Colifagos $(U F P / 100 m l)$ & & 300 & 430 & 200 & 300 & & 0 & 0 & 20 & 0 & 0 & 0 \\
\hline C. total $(U F C / 100 m l)$ & & $16.10^{5}$ & $30.10^{5}$ & $8.10^{5}$ & $18.10^{5}$ & & $51.10^{2}$ & $35.10^{2}$ & $59.10^{2}$ & $32.10^{2}$ & $3.10^{2}$ & $6.10^{2}$ \\
\hline C. perfringens $(N M P / 100 m l)$ & & $33.10^{2}$ & $30.10^{2}$ & $6.10^{2}$ & $34.10^{2}$ & & 260 & 800 & 600 & 330 & 20 & 90 \\
\hline E. $\operatorname{coli}(U F C / 100 m l)$ & & $16.10^{4}$ & $10.10^{4}$ & $12.10^{4}$ & $10.10^{4}$ & & 10 & 0 & 0 & 0 & 0 & 10 \\
\hline
\end{tabular}

[a] Etapa 1: mg/L. [b] Etapa 2: $\mathrm{mW} . \mathrm{s} / \mathrm{cm}^{2}$.

T: Tempo de contato (s). Unidade 1: Método convencional. Unidade 2: Método alternativo.

P1: Efluente bruto. P2-o: Efluente bruto após ozonização. P3-o, : Efluente ozonizado seguido de tratamento biológico. P2-uv: Efluente após irradiação com UV.

P3-uv: Efluente após irradiação com UV seguido de tratamento biológico. P4: Efluente bruto seguido de tratamento biológico. 
Tabela 8.11: Caracterização das amostras coletadas no ensaio 3 para a seqüência $U V / O_{3}$.

\begin{tabular}{|c|c|c|c|c|c|c|c|c|c|c|c|c|}
\hline & \multicolumn{5}{|c|}{ Etapa 1 - Pré-desinfecção } & \multicolumn{7}{|c|}{ Etapa 2 - Desinfecção } \\
\hline & \multirow[b]{2}{*}{ A: } & \multicolumn{4}{|c|}{ Unidade 1 e 2} & \multirow[b]{2}{*}{$\mathrm{T}:$} & \multicolumn{3}{|c|}{ Unidade 1} & \multicolumn{3}{|c|}{ Unidade 2} \\
\hline & & $\mathrm{P} 1$ & $\mathrm{P} 2-\mathrm{uv}$ & P3-uv & $\mathrm{P} 4$ & & 5 & 7 & 10 & 5 & 7 & 10 \\
\hline Alcalinidade $(m g / L)$ & & 109 & 76 & 19 & 61 & & 36 & 55 & 50 & 15 & 9 & 11 \\
\hline $\operatorname{DQO}(m g / L)$ & & 278 & 94 & 36 & 195 & & 297 & 208 & 224 & 41 & 34 & 38 \\
\hline Dose efetiva $^{a b}$ & & - & 51 & - & - & & 31 & 31 & 31 & 34 & 30 & 31 \\
\hline $\mathrm{pH}$ & & 7,0 & 6,5 & 5,0 & 6,2 & & 6,2 & 6,3 & 6,4 & 5,9 & 5,4 & 5,2 \\
\hline $\operatorname{SST}(m g / L)$ & & 149 & 16 & 18 & 56 & & 80 & 111 & 132 & 18 & 102 & 22 \\
\hline $\operatorname{SSV}(m g / L)$ & & 103 & 6 & 3 & 45 & & 72 & 70 & 38 & 3 & 34 & 20 \\
\hline Colifagos $(U F P / 100 m l)$ & & $10.10^{3}$ & $5.10^{2}$ & 0 & $12.10^{3}$ & & 30 & 25 & 20 & 0 & 0 & 0 \\
\hline C. total $(U F C / 100 m l)$ & & $23.10^{5}$ & $6.10^{3}$ & $1.10^{5}$ & $7.10^{5}$ & & $11.10^{3}$ & $74.10^{2}$ & $39.10^{2}$ & 100 & 0 & 100 \\
\hline C. perfringens $(N M P / 100 m l)$ & & 2.300 & 2.200 & 600 & 1.700 & & 110 & 270 & 220 & 40 & 60 & 60 \\
\hline E. coli $(U F C / 100 m l)$ & & $15.10^{5}$ & $6.10^{3}$ & $1.10^{4}$ & $75.10^{4}$ & & $12.10^{3}$ & $74.10^{2}$ & $39.10^{2}$ & 20 & 0 & 20 \\
\hline
\end{tabular}

[a] Etapa 1: $\mathrm{mW} \cdot \mathrm{s} / \mathrm{cm}^{2}$. [b] Etapa 2: $\mathrm{mg} / \mathrm{L}$.

T: Tempo de contato (min). Unidade 1: Método convencional. Unidade 2: Método alternativo.

P1: Efluente bruto. P2-o 3 : Efluente bruto após ozonização. P3-o 3: Efluente ozonizado seguido de tratamento biológico. P2-uv: Efluente após irradiação com UV.

P3-uv: Efluente após irradiação com UV seguido de tratamento biológico. P4: Efluente bruto seguido de tratamento biológico. 


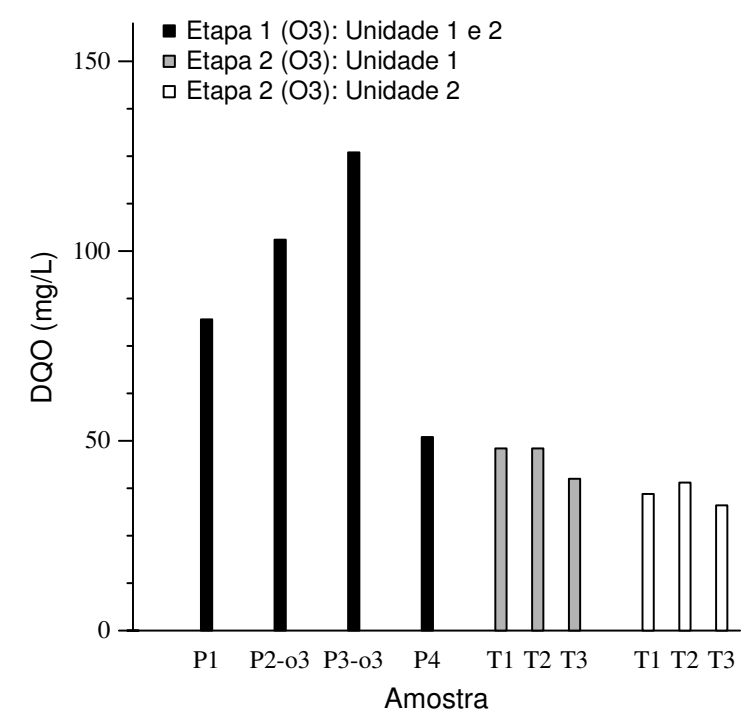

(a) $\mathrm{O}_{3} / \mathrm{O}_{3}$ (T1:5min.T2:7min.T3:10min.)

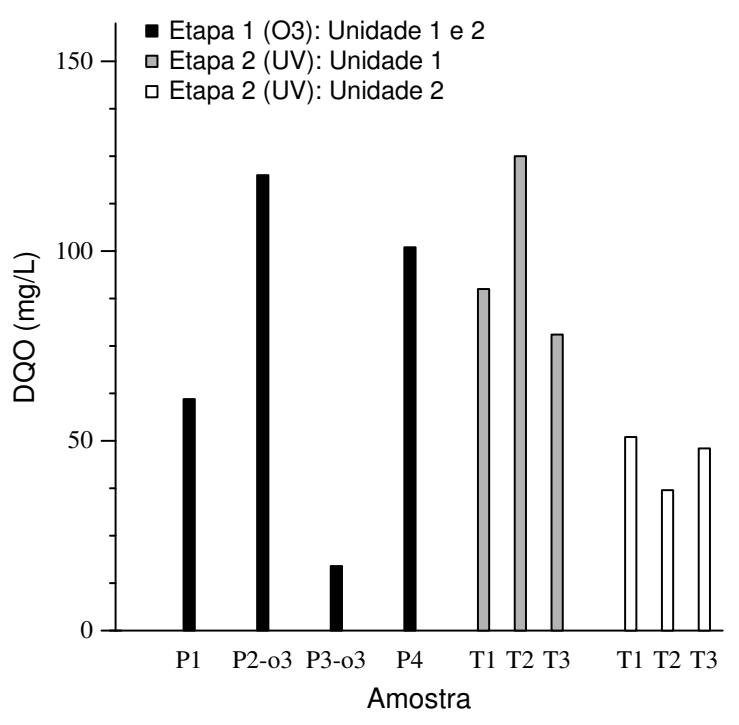

(b) $\mathrm{O}_{3} / \mathrm{UV}(\mathrm{T} 1: 30 \mathrm{~s} \cdot \mathrm{T} 2: 60 \mathrm{~s} \cdot \mathrm{T} 3: 120 \mathrm{~s}$.)

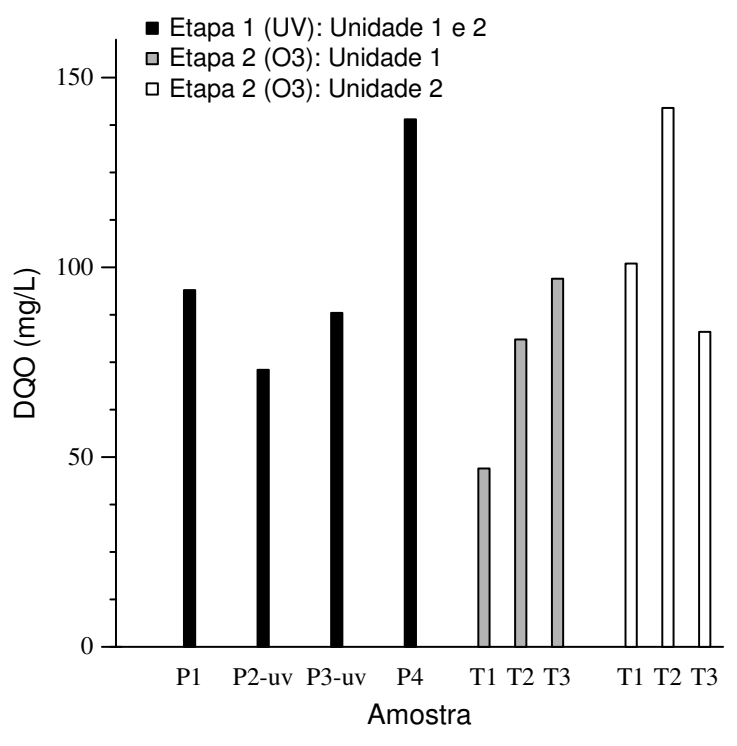

(c) $\mathrm{UV} / \mathrm{O}_{3}$ (T1:5min.T2:7min.T3:10min.)

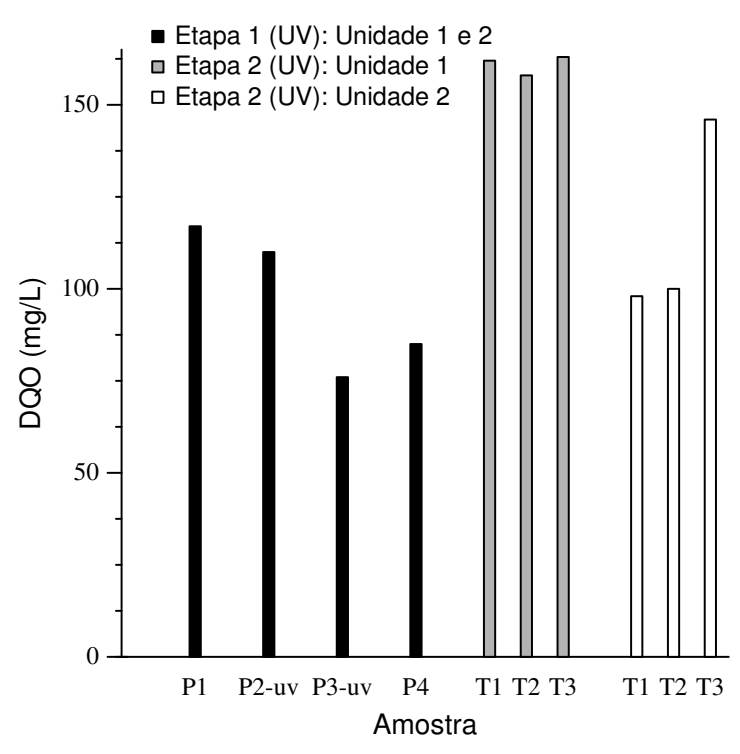

(d) UV/UV (T1:30s.T2:60s.T3:120s.)

Figura 8.1: Variação da DQO nas etapas 1 e 2 (ensaio 1).

P1: Efluente bruto. P2-o ${ }_{3}$ : Efluente bruto após ozonização. P3-o 3 : Efluente ozonizado seguido de tratamento biológico. P2-uv: Efluente após irradiação com UV. P3-uv: Efluente após irradiação com UV seguido de tratamento biológico. P4: Efluente bruto seguido de tratamento biológico. T1, T2, T3: Tempos de contato. Etapa 1: Pré-desinfecção. Etapa 2: Desinfecção. Unidade 1: método convencional. Unidade 2: Método alternativo. 


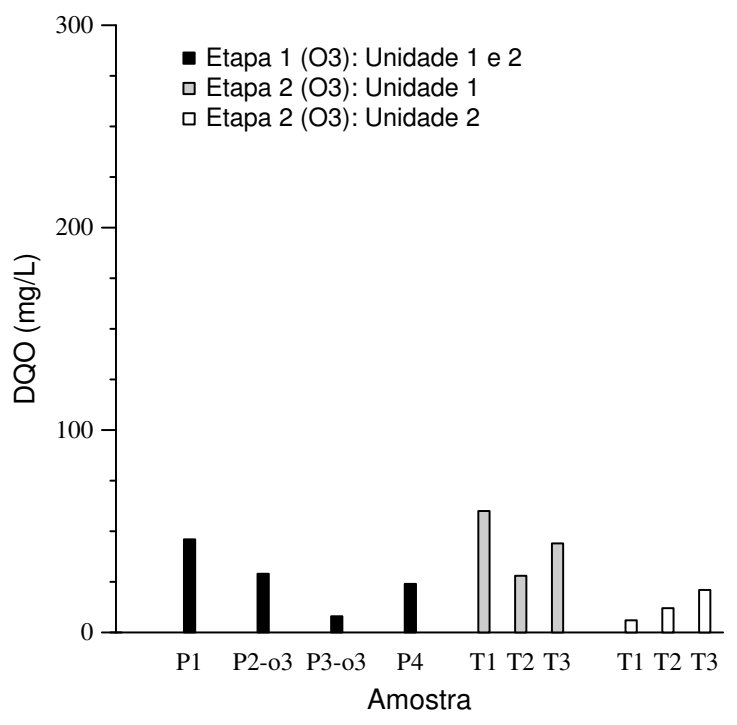

(a) $\mathrm{O}_{3} / \mathrm{O}_{3}$ (T1:5min.T2:7min.T3:10min.)

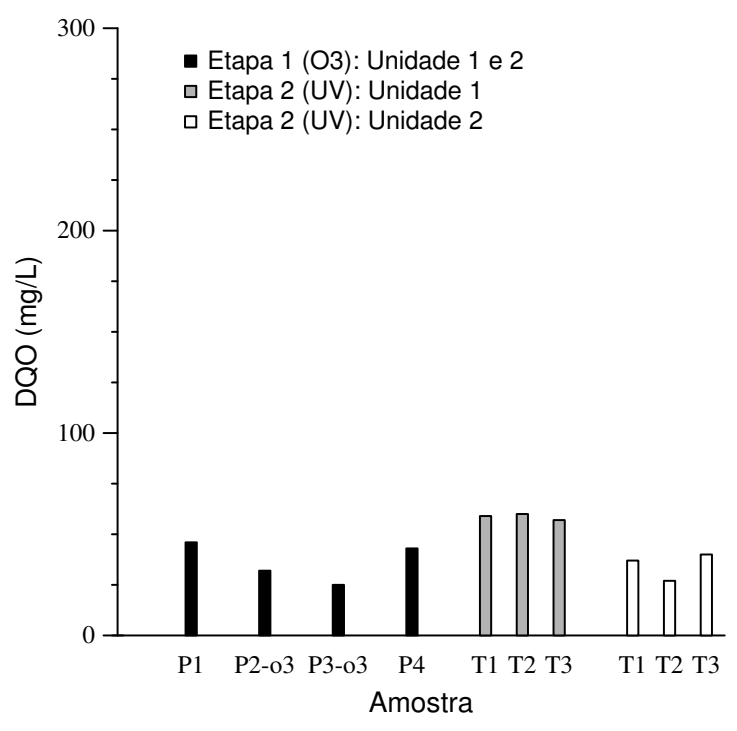

(b) $\mathrm{O}_{3} / \mathrm{UV}(\mathrm{T} 1: 30 \mathrm{~s} \cdot \mathrm{T} 2: 60 \mathrm{~s} \cdot \mathrm{T} 3: 120 \mathrm{~s}$.

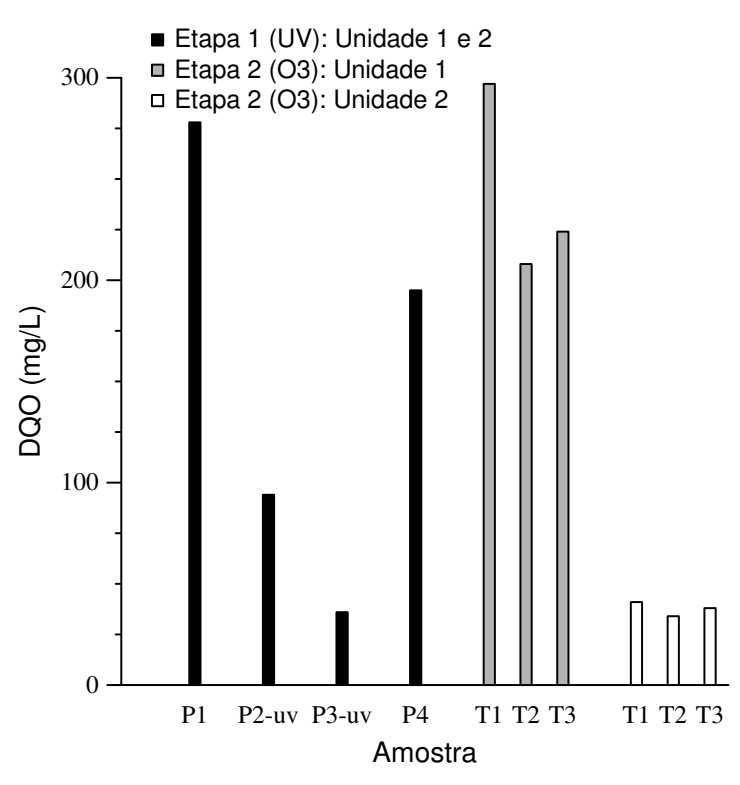

(c) $\mathrm{UV} / \mathrm{O}_{3}$ (T1:5min.T2:7min.T3:10min.)

Figura 8.2: Variação da DQO nas etapas 1 e 2 (ensaio 3).

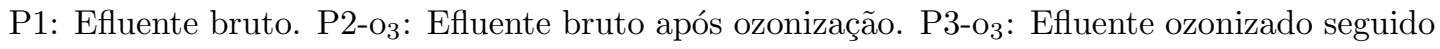
de tratamento biológico. P2-uv: Efluente após irradiação com UV. P3-uv: Efluente após irradiação com UV seguido de tratamento biológico. P4: Efluente bruto seguido de tratamento biológico. T1, T2, T3: Tempos de contato. Etapa 1: Pré-desinfecção. Etapa 2: Desinfecção. Unidade 1: método convencional. Unidade 2: Método alternativo. 


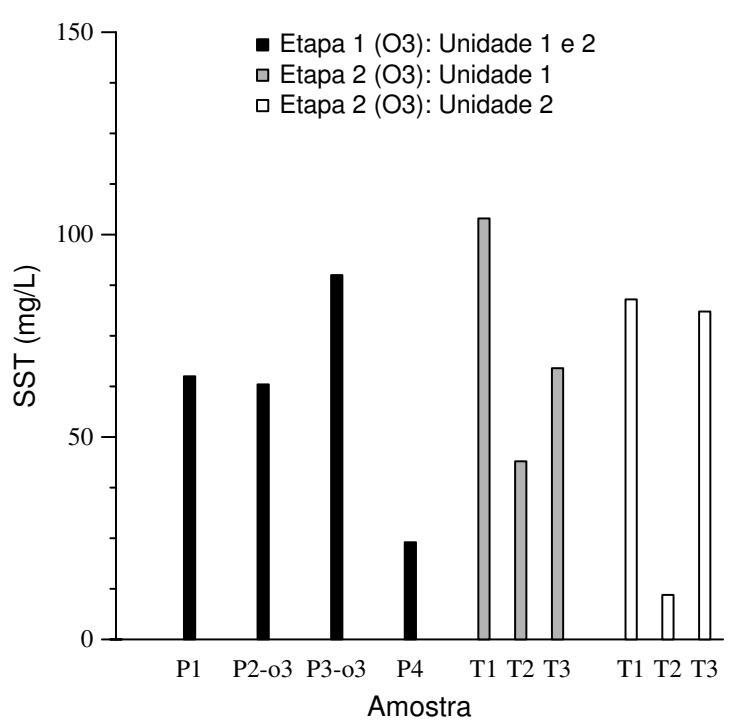

(a) $\mathrm{O}_{3} / \mathrm{O}_{3}$ (T1:5min.T2:7min.T3:10min.)

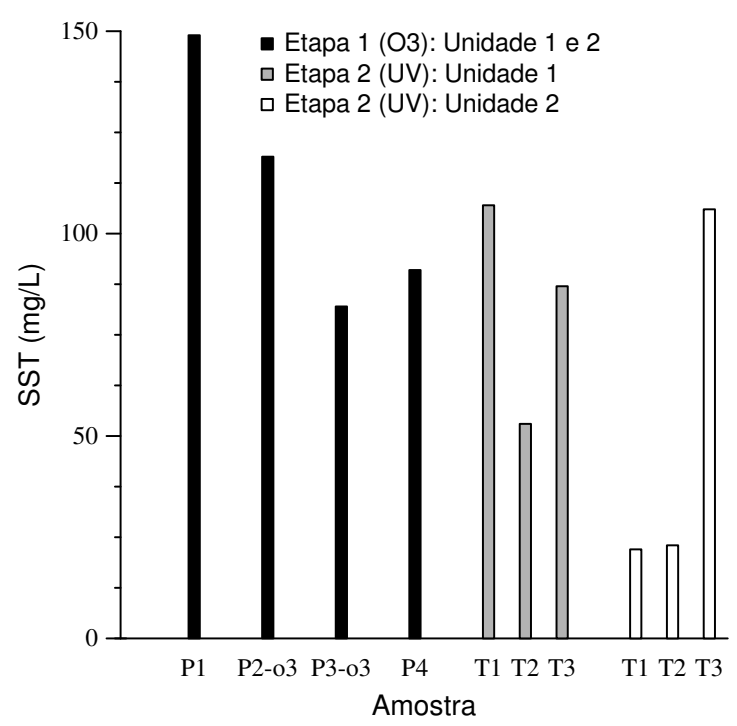

(b) $\mathrm{O}_{3} / \mathrm{UV}$ (T1:30s.T2:60s.T3:120s.)

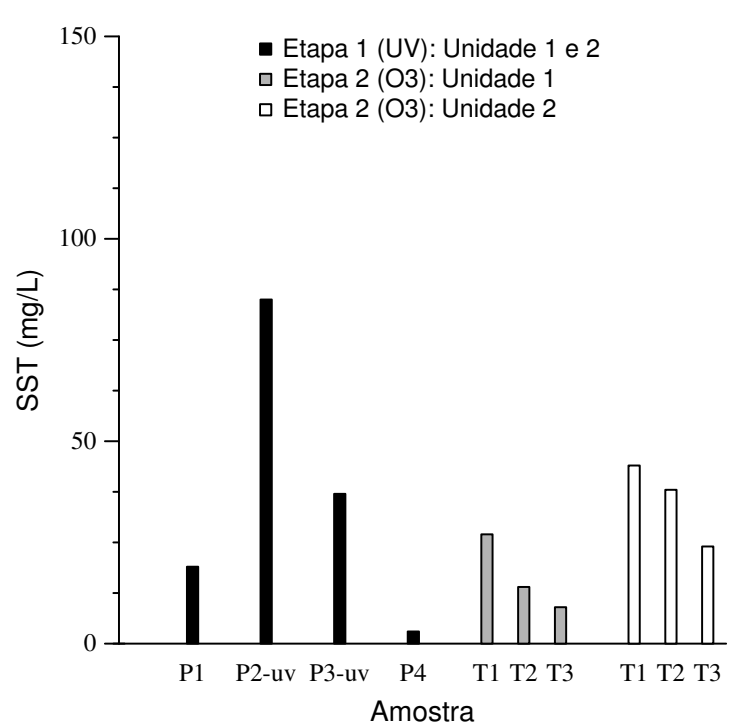

(c) $\mathrm{UV} / \mathrm{O}_{3}$ (T1:5min.T2:7min.T3:10min.)

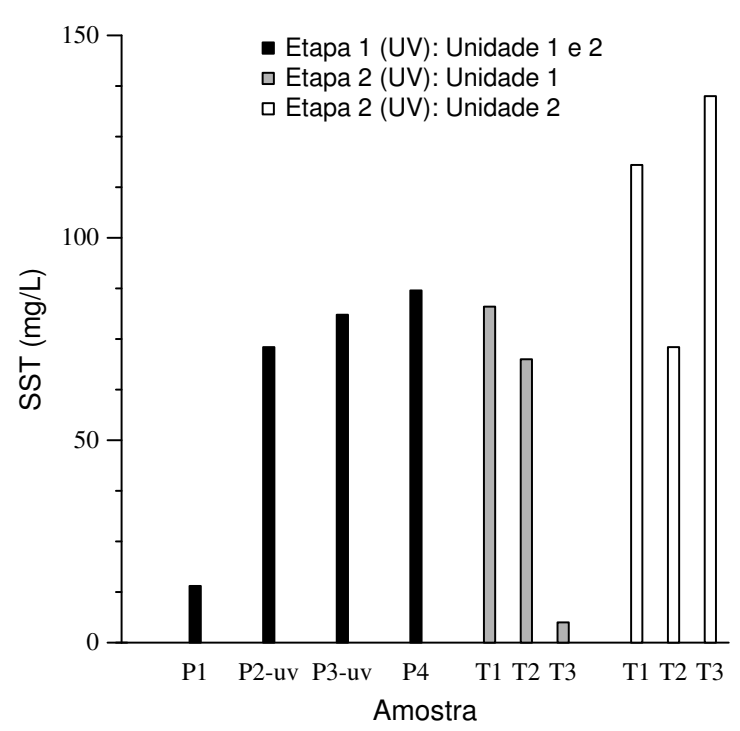

(d) UV/UV (T1:30s.T2:60s.T3:120s.)

Figura 8.3: Variação da concentração de SST nas etapas 1 e 2 (ensaio 1).

P1: Efluente bruto. P2-o $\mathrm{o}_{3}$ : Efluente bruto após ozonização. P3-o $\mathrm{o}_{3}$ : Efluente ozonizado seguido de tratamento biológico. P2-uv: Efluente após irradiação com UV. P3-uv: Efluente após irradiação com UV seguido de tratamento biológico. P4: Efluente bruto seguido de tratamento biológico. T1, T2, T3: Tempos de contato. Etapa 1: Pré-desinfecção. Etapa 2: Desinfecção. Unidade 1: método convencional. Unidade 2: Método alternativo. 


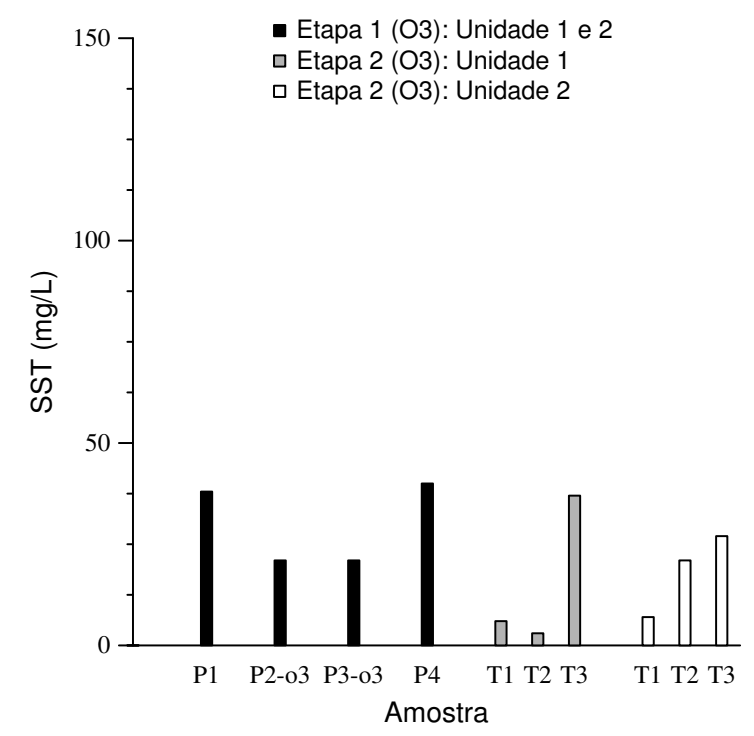

(a) $\mathrm{O}_{3} / \mathrm{O}_{3}$ (T1:5min.T2:7min.T3:10min.)

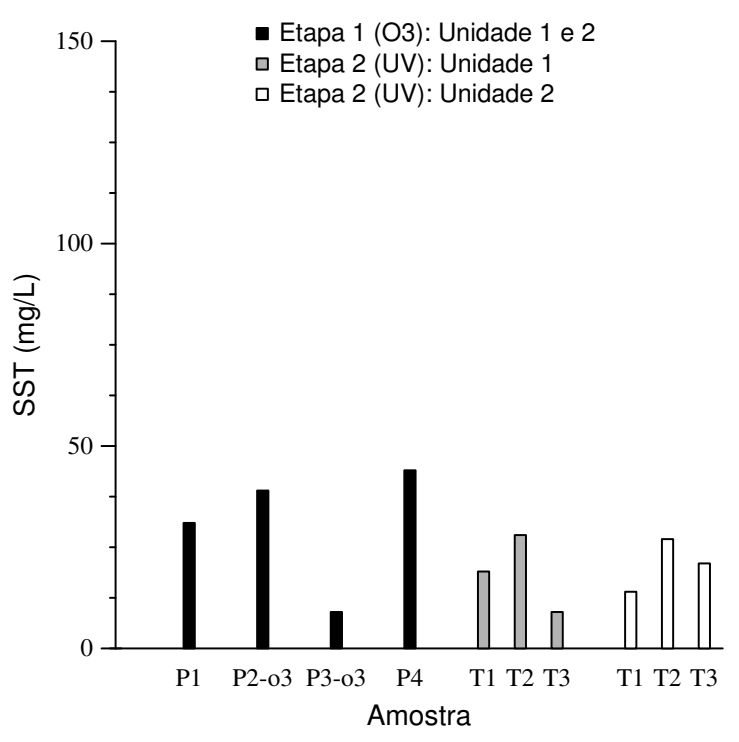

(b) $\mathrm{O}_{3} / \mathrm{UV}$ (T1:30s.T2:60s.T3:120s.)

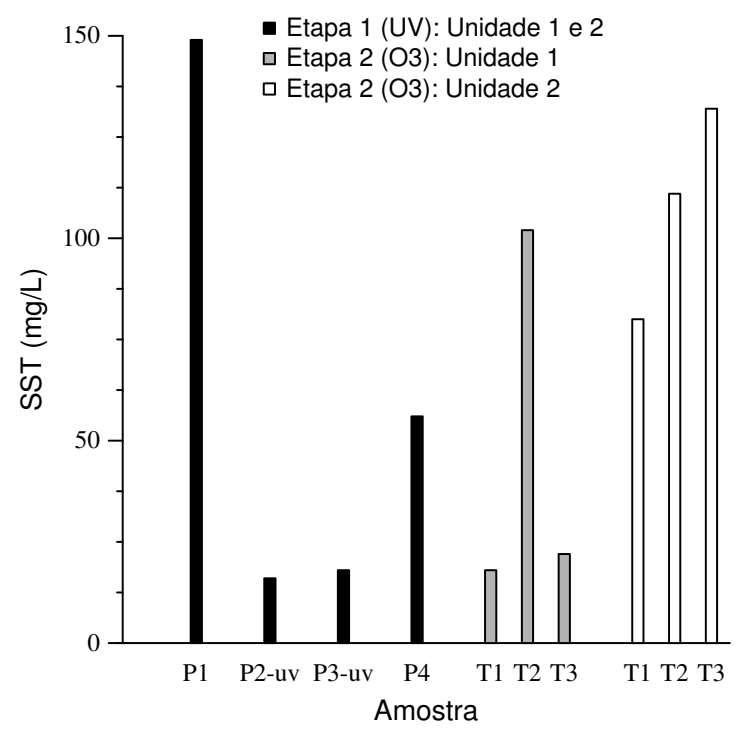

(c) $\mathrm{UV} / \mathrm{O}_{3}$ (T1:5min.T2:7min.T3:10min.)

Figura 8.4: Variação da concentração de SST nas etapas 1 e 2 (ensaio 3).

P1: Efluente bruto. P2-o o $_{3}$ Efluente bruto após ozonização. P3-o ${ }_{3}$ : Efluente ozonizado seguido de tratamento biológico. P2-uv: Efluente após irradiação com UV. P3-uv: Efluente após irradiação com UV seguido de tratamento biológico. P4: Efluente bruto seguido de tratamento biológico. T1, T2, T3: Tempos de contato. Etapa 1: Pré-desinfecção. Etapa 2: Desinfecção. Unidade 1: método convencional. Unidade 2: Método alternativo. 


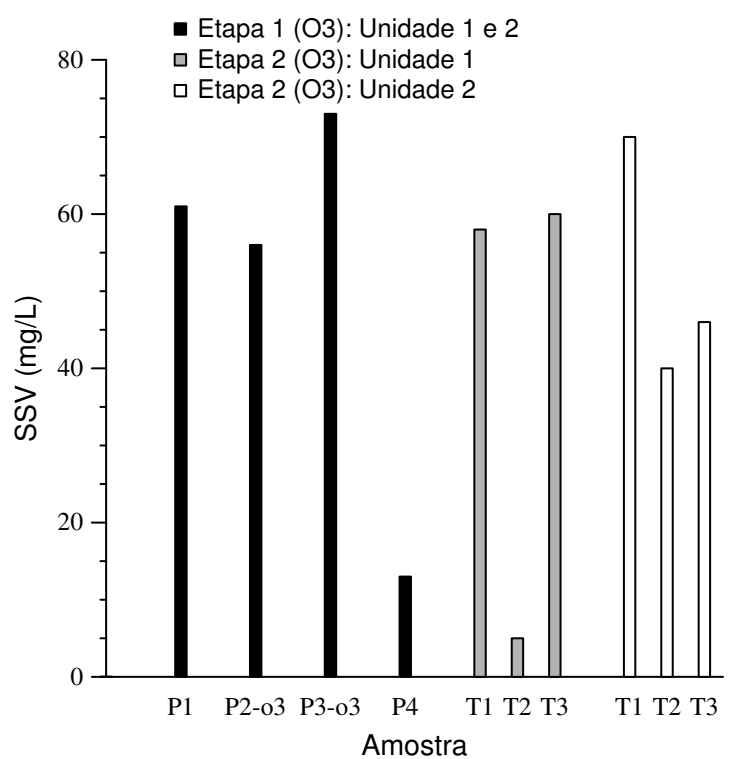

(a) $\mathrm{O}_{3} / \mathrm{O}_{3}(\mathrm{~T} 1: 5 \mathrm{~min} . \mathrm{T} 2: 7 \mathrm{~min} . \mathrm{T} 3: 10 \mathrm{~min}$.)

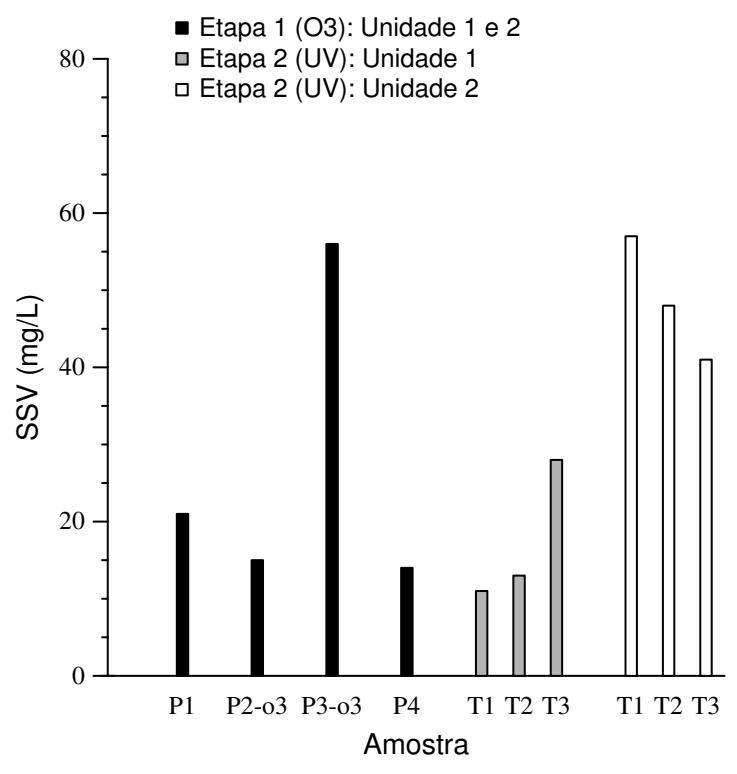

(b) $\mathrm{O}_{3} / \mathrm{UV}$ (T1:30s.T2:60s.T3:120s.)

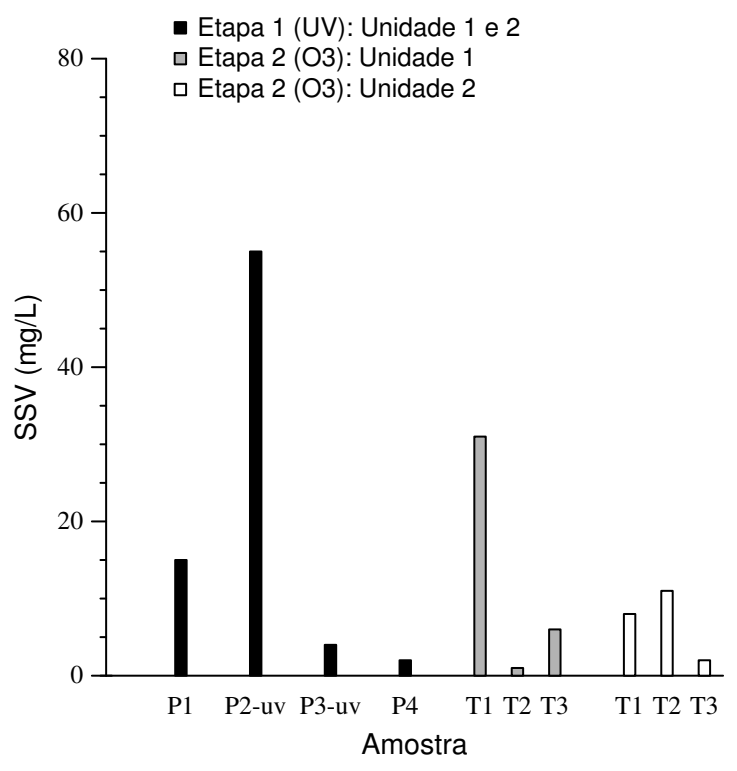

(c) $\mathrm{UV} / \mathrm{O}_{3}$ (T1:5min.T2:7min.T3:10min.)

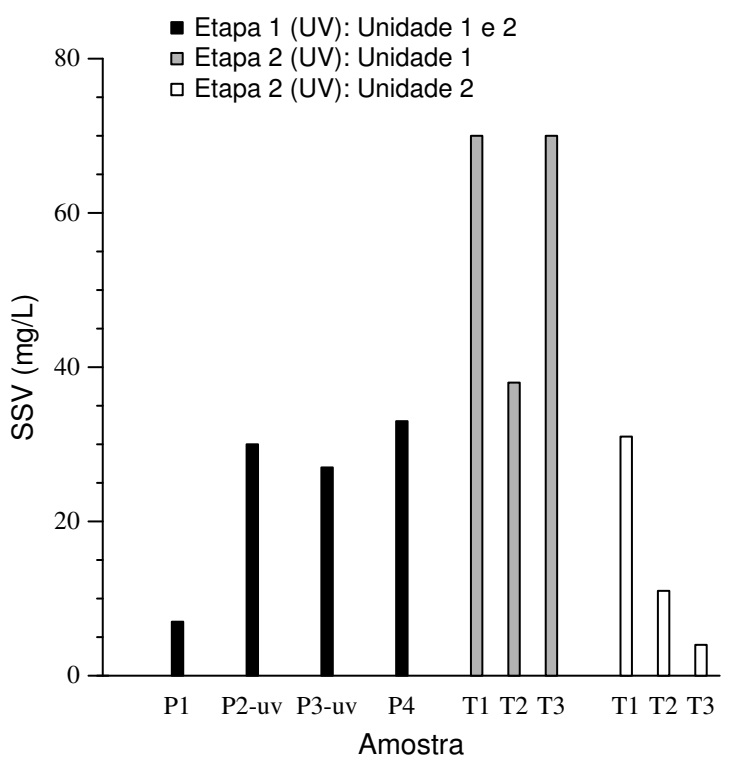

(d) UV/UV (T1:30s.T2:60s.T3:120s.)

Figura 8.5: Variação da concentração de SSV nas etapas 1 e 2 (ensaio 1).

P1: Efluente bruto. P2-o 3 : Efluente bruto após ozonização. P3-- 3 : Efluente ozonizado seguido de tratamento biológico. P2-uv: Efluente após irradiação com UV. P3-uv: Efluente após irradiação com UV seguido de tratamento biológico. P4: Efluente bruto seguido de tratamento biológico. T1, T2, T3: Tempos de contato. Etapa 1: Pré-desinfecção. Etapa 2: Desinfecção. Unidade 1: método convencional. Unidade 2: Método alternativo. 


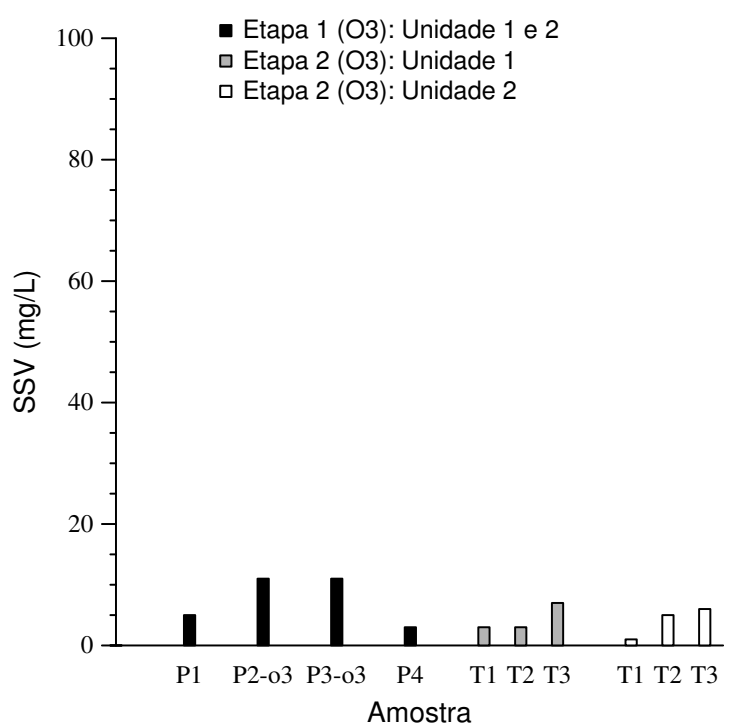

(a) $\mathrm{O}_{3} / \mathrm{O}_{3}$ (T1:5min.T2:7min.T3:10min.)

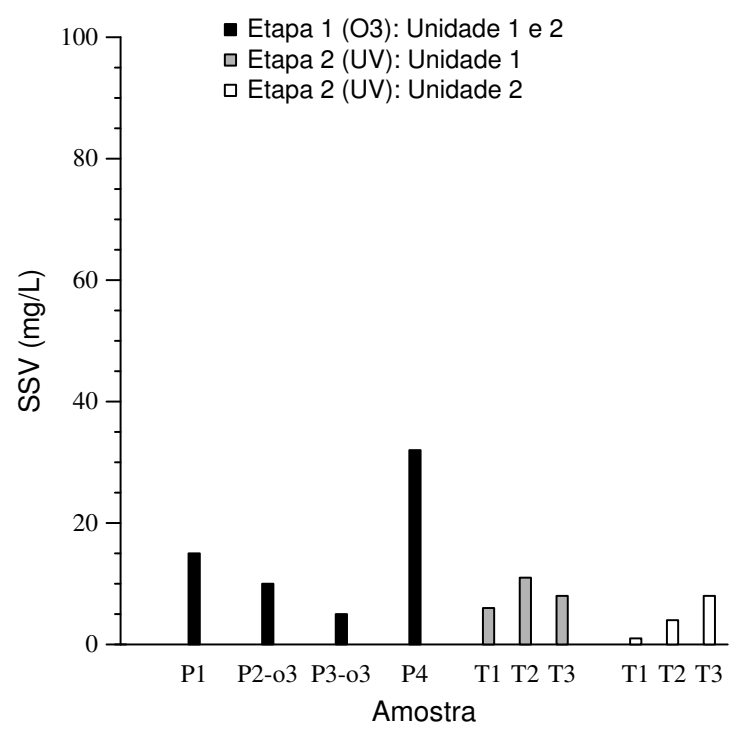

(b) $\mathrm{O}_{3} / \mathrm{UV}$ (T1:30s.T2:60s.T3:120s.)

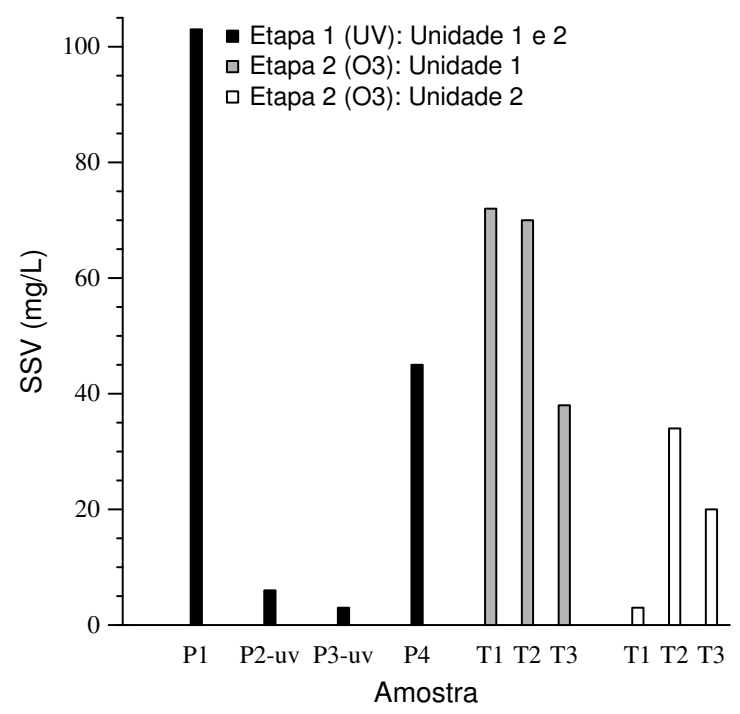

(c) $\mathrm{UV} / \mathrm{O}_{3}$ (T1:5min.T2:7min.T3:10min.)

Figura 8.6: Variação da concentração de SSV nas etapas 1 e 2 (ensaio 3).

P1: Efluente bruto. P2-o ${ }_{3}$ : Efluente bruto após ozonização. P3-o 3 : Efluente ozonizado seguido de tratamento biológico. P2-uv: Efluente após irradiação com UV. P3-uv: Efluente após irradiação com UV seguido de tratamento biológico. P4: Efluente bruto seguido de tratamento biológico. T1, T2, T3: Tempos de contato. Etapa 1: Pré-desinfecção. Etapa 2: Desinfecção. Unidade 1: método convencional. Unidade 2: Método alternativo. 
Tabela 8.12: Variação da população de Escherichia coli (ensaios 1 e 3).

\begin{tabular}{|c|c|c|c|c|c|c|c|c|c|c|c|c|c|c|c|c|c|c|c|c|c|}
\hline & & \multirow[b]{3}{*}{ A: } & \multicolumn{5}{|c|}{ Etapa 1 - Pré-desinfecção } & \multirow[b]{3}{*}{$\mathrm{T}_{1}:$} & \multicolumn{13}{|c|}{ Etapa 2 - Desinfecção } \\
\hline & & & \multicolumn{4}{|c|}{ Sobreviventes $^{a}$} & \multirow{2}{*}{$\frac{D o s e^{b c}}{\mathrm{P} 2}$} & & \multicolumn{3}{|c|}{ Sobreviventes ${ }^{a}$} & \multicolumn{3}{|c|}{$D o s e^{b}$} & \multirow[b]{2}{*}{$\mathrm{T}_{2}:$} & \multicolumn{3}{|c|}{ Sobreviventes ${ }^{a}$} & \multicolumn{3}{|c|}{$D o s e^{c}$} \\
\hline & & & $\mathrm{P} 1$ & $\mathrm{P} 2$ & P3 & $\mathrm{P} 4$ & & & 5 & 7 & 10 & 5 & 7 & 10 & & 30 & 60 & 120 & 30 & 60 & 120 \\
\hline \multirow[t]{8}{*}{ Ensaio1 } & $-/ \mathrm{O}_{3}$ & & $10^{5}$ & - & - & $10^{4}$ & - & & $10^{0}$ & $10^{1}$ & $10^{1}$ & 32 & 32 & 36 & & - & - & - & - & - & - \\
\hline & $\mathrm{O}_{3} / \mathrm{O}_{3}$ & & $10^{5}$ & $10^{4}$ & $10^{4}$ & - & 1 & & 0 & 0 & 0 & 30 & 31 & 29 & & - & - & - & - & - & - \\
\hline & $-/ \mathrm{O}_{3}$ & & $10^{6}$ & - & - & $10^{5}$ & - & & $10^{2}$ & $10^{1}$ & $10^{2}$ & 28 & 28 & 28 & & - & - & - & - & - & - \\
\hline & $\mathrm{UV} / \mathrm{O}_{3}$ & & $10^{6}$ & $10^{4}$ & $10^{4}$ & - & 51 & & 0 & 0 & $10^{1}$ & 22 & 27 & 27 & & - & - & - & - & - & - \\
\hline & $-/ \mathrm{UV}$ & & $10^{5}$ & - & - & $10^{5}$ & - & & - & - & - & - & - & - & & $10^{2}$ & $10^{2}$ & $10^{3}$ & 66 & 138 & 288 \\
\hline & $\mathrm{O}_{3} / \mathrm{UV}$ & & $10^{5}$ & $10^{5}$ & $10^{5}$ & - & 1 & & - & - & - & - & - & - & & 0 & 0 & $10^{2}$ & 72 & 150 & 324 \\
\hline & $-/ \mathrm{UV}$ & & $10^{6}$ & - & - & $10^{5}$ & - & & - & - & - & - & - & - & & $10^{2}$ & $10^{1}$ & $10^{2}$ & 60 & 114 & 228 \\
\hline & $\mathrm{UV} / \mathrm{UV}$ & & $10^{6}$ & $10^{5}$ & $10^{4}$ & - & 51 & & - & - & - & - & - & - & & $10^{1}$ & $10^{1}$ & 0 & 54 & 108 & 216 \\
\hline \multirow[t]{6}{*}{ Ensaio3 } & $-/ \mathrm{O}_{3}$ & & $10^{5}$ & - & - & $10^{4}$ & - & & $10^{1}$ & $10^{1}$ & 0 & 25 & 25 & 29 & & - & - & - & - & - & - \\
\hline & $\mathrm{O}_{3} / \mathrm{O}_{3}$ & & $10^{5}$ & $10^{5}$ & $10^{4}$ & - & 1 & & 0 & $10^{0}$ & 0 & 30 & 24 & 21 & & - & - & - & - & - & - \\
\hline & $-/ \mathrm{O}_{3}$ & & $10^{6}$ & - & - & $10^{5}$ & - & & $10^{4}$ & $10^{3}$ & $10^{3}$ & 31 & 31 & 31 & & - & - & - & - & - & - \\
\hline & $\mathrm{UV} / \mathrm{O}_{3}$ & & $10^{6}$ & $10^{3}$ & $10^{4}$ & - & 51 & & $10^{0}$ & 0 & $10^{0}$ & 34 & 30 & 31 & & - & - & - & - & - & - \\
\hline & $-/ \mathrm{UV}$ & & $10^{5}$ & - & - & $10^{5}$ & - & & - & - & - & - & - & - & & $10^{1}$ & 0 & 0 & 66 & 108 & 216 \\
\hline & $\mathrm{O}_{3} / \mathrm{UV}$ & & $10^{5}$ & $10^{5}$ & $10^{5}$ & - & 1 & & - & - & - & - & - & - & & 0 & 0 & 0 & 54 & 132 & 264 \\
\hline
\end{tabular}

$\mathrm{T}_{1}$ : Tempo de contato, $\mathrm{O}_{3}(\mathrm{~min}) . \mathrm{T}_{2}$ : Tempo de contato, UV (s). [a] Número de sobreviventes em ordem de grandeza (UFC/100mL). [b] O $3: \mathrm{mg} / \mathrm{L}$. [c] UV:mW.s/cm².

P1: Efluente bruto. P2: Efluente bruto após pré-desinfecção. P3: Efluente após pré-desinfecção seguido de tratamento biológico.

P4: Efluente bruto seguido de tratamento biológico. 
Tabela 8.13: Variação da população de colifagos (ensaios 1 e 3).

\begin{tabular}{|c|c|c|c|c|c|c|c|c|c|c|c|c|c|c|c|c|c|c|c|c|c|}
\hline & & \multirow[b]{3}{*}{ A: } & \multicolumn{5}{|c|}{ Etapa 1 - Pré-desinfecção } & \multirow[b]{3}{*}{$\mathrm{T}_{1}:$} & \multicolumn{13}{|c|}{ Etapa 2 - Desinfecção } \\
\hline & & & \multicolumn{4}{|c|}{ Sobreviventes $^{a}$} & \multirow{2}{*}{$\begin{array}{c}\text { Dose }^{b c} \\
\text { P2 }\end{array}$} & & \multicolumn{3}{|c|}{ Sobreviventes ${ }^{a}$} & \multicolumn{3}{|c|}{$D o s e^{b}$} & \multirow[b]{2}{*}{$\mathrm{T}_{2}:$} & \multicolumn{3}{|c|}{ Sobreviventes $^{a}$} & \multicolumn{3}{|c|}{$D_{o s e}^{c}$} \\
\hline & & & $\mathrm{P} 1$ & $\mathrm{P} 2$ & P3 & $\mathrm{P} 4$ & & & 5 & 7 & 10 & 5 & 7 & 10 & & 30 & 60 & 120 & 30 & 60 & 120 \\
\hline \multirow[t]{8}{*}{ Ensaio1 } & $-/ \mathrm{O}_{3}$ & & $10^{3}$ & - & - & $10^{3}$ & - & & 0 & $10^{1}$ & $10^{1}$ & 32 & 32 & 36 & & - & - & - & - & - & - \\
\hline & $\mathrm{O}_{3} / \mathrm{O}_{3}$ & & $10^{3}$ & $10^{3}$ & $10^{2}$ & - & 1 & & 0 & $10^{0}$ & 0 & 30 & 31 & 29 & & - & - & - & - & - & - \\
\hline & $-/ \mathrm{O}_{3}$ & & $10^{3}$ & - & - & $10^{3}$ & - & & $10^{1}$ & 0 & 0 & 28 & 28 & 28 & & - & - & - & - & - & - \\
\hline & $\mathrm{UV} / \mathrm{O}_{3}$ & & $10^{3}$ & $10^{1}$ & $10^{2}$ & - & 51 & & $10^{1}$ & 0 & 0 & 22 & 27 & 27 & & - & - & - & - & - & - \\
\hline & $-/ \mathrm{UV}$ & & $10^{3}$ & - & - & $10^{3}$ & - & & - & - & - & - & - & - & & 0 & $10^{1}$ & $10^{0}$ & 66 & 138 & 288 \\
\hline & $\mathrm{O}_{3} / \mathrm{UV}$ & & $10^{3}$ & $10^{3}$ & 0 & - & 1 & & - & - & - & - & - & - & & 0 & 0 & 0 & 72 & 150 & 324 \\
\hline & $-/ \mathrm{UV}$ & & $10^{3}$ & - & - & $10^{3}$ & - & & - & - & - & - & - & - & & 0 & 0 & 0 & 60 & 114 & 228 \\
\hline & $\mathrm{UV} / \mathrm{UV}$ & & $10^{3}$ & $10^{2}$ & $10^{2}$ & - & 51 & & - & - & - & - & - & - & & 0 & 0 & 0 & 54 & 108 & 216 \\
\hline \multirow[t]{6}{*}{ Ensaio3 } & $-/ \mathrm{O}_{3}$ & & $10^{3}$ & - & - & $10^{3}$ & - & & $10^{1}$ & $10^{1}$ & $10^{1}$ & 25 & 25 & 29 & & - & - & - & - & - & - \\
\hline & $\mathrm{O}_{3} / \mathrm{O}_{3}$ & & $10^{3}$ & $10^{3}$ & $10^{2}$ & - & 1 & & $10^{1}$ & 0 & 0 & 30 & 24 & 21 & & - & - & - & - & - & - \\
\hline & $-/ \mathrm{O}_{3}$ & & $10^{4}$ & - & - & $10^{4}$ & - & & $10^{1}$ & $10^{1}$ & $10^{1}$ & 31 & 31 & 31 & & - & - & - & - & - & - \\
\hline & $\mathrm{UV} / \mathrm{O}_{3}$ & & $10^{4}$ & $10^{2}$ & 0 & - & 51 & & 0 & 0 & 0 & 34 & 30 & 31 & & - & - & - & - & - & - \\
\hline & $-/ \mathrm{UV}$ & & $10^{2}$ & - & - & $10^{2}$ & - & & - & - & - & - & - & - & & 0 & 0 & $10^{1}$ & 66 & 108 & 216 \\
\hline & $\mathrm{O}_{3} / \mathrm{UV}$ & & $10^{2}$ & $10^{2}$ & $10^{2}$ & - & 1 & & - & - & - & - & - & - & & 0 & 0 & 0 & 54 & 132 & 264 \\
\hline
\end{tabular}

$\mathrm{T}_{1}$ : Tempo de contato, $\mathrm{O}_{3}(\mathrm{~min}) . \mathrm{T}_{2}$ : Tempo de contato, UV (s). [a] Número de sobreviventes em ordem de grandeza (UFP/100mL). [b] O $3: \mathrm{mg} / \mathrm{L}$. [c] UV:mW.s/cm² .

P1: Efluente bruto. P2: Efluente bruto após pré-desinfecção. P3: Efluente após pré-desinfecção seguido de tratamento biológico.

P4: Efluente bruto seguido de tratamento biológico. 
Tabela 8.14: Variação da população de Clostridium perfringens (ensaios 1 e 3).

\begin{tabular}{|c|c|c|c|c|c|c|c|c|c|c|c|c|c|c|c|c|c|c|c|c|c|}
\hline & & \multirow[b]{3}{*}{ A: } & \multicolumn{5}{|c|}{ Etapa 1 - Pré-desinfecção } & \multirow[b]{3}{*}{$\mathrm{T}_{1}:$} & \multicolumn{13}{|c|}{ Etapa 2 - Desinfecção } \\
\hline & & & \multicolumn{4}{|c|}{ Sobreviventes ${ }^{a}$} & \multirow{2}{*}{$\begin{array}{c}\text { Dose }^{b c} \\
\text { P2 }\end{array}$} & & \multicolumn{3}{|c|}{ Sobreviventes $^{a}$} & \multicolumn{3}{|c|}{$D o s e^{b}$} & \multirow[b]{2}{*}{$\mathrm{T}_{2}:$} & \multicolumn{3}{|c|}{ Sobreviventes ${ }^{a}$} & \multicolumn{3}{|c|}{$D_{o s e}^{c}$} \\
\hline & & & $\mathrm{P} 1$ & $\mathrm{P} 2$ & $\mathrm{P} 3$ & $\mathrm{P} 4$ & & & 5 & 7 & 10 & 5 & 7 & 10 & & 30 & 60 & 120 & 30 & 60 & 120 \\
\hline \multirow[t]{8}{*}{ Ensaio1 } & $-/ \mathrm{O}_{3}$ & & $10^{4}$ & - & - & $10^{4}$ & - & & $10^{1}$ & $10^{3}$ & $10^{3}$ & 32 & 32 & 36 & & - & - & - & - & - & - \\
\hline & $\mathrm{O}_{3} / \mathrm{O}_{3}$ & & $10^{4}$ & $10^{3}$ & $10^{3}$ & - & 1 & & $10^{2}$ & $10^{2}$ & $10^{2}$ & 30 & 31 & 29 & & - & - & - & - & - & - \\
\hline & $-/ \mathrm{O}_{3}$ & & $10^{3}$ & - & - & $10^{3}$ & - & & $10^{2}$ & $10^{2}$ & $10^{2}$ & 28 & 28 & 28 & & - & - & - & - & - & - \\
\hline & $\mathrm{UV} / \mathrm{O}_{3}$ & & $10^{3}$ & $10^{2}$ & $10^{2}$ & - & 51 & & $10^{1}$ & $10^{2}$ & $10^{1}$ & 22 & 27 & 27 & & - & - & - & - & - & - \\
\hline & $-/ \mathrm{UV}$ & & $10^{2}$ & - & - & $10^{2}$ & - & & - & - & - & - & - & - & & $10^{1}$ & $10^{1}$ & $10^{1}$ & 66 & 138 & 288 \\
\hline & $\mathrm{O}_{3} / \mathrm{UV}$ & & $10^{2}$ & $10^{2}$ & $10^{2}$ & - & 1 & & - & - & - & - & - & - & & $10^{1}$ & $10^{1}$ & 0 & 72 & 150 & 324 \\
\hline & $-/ \mathrm{UV}$ & & $10^{4}$ & - & - & $10^{4}$ & - & & - & - & - & - & - & - & & $10^{3}$ & $10^{3}$ & $10^{2}$ & 60 & 114 & 228 \\
\hline & $\mathrm{UV} / \mathrm{UV}$ & & $10^{4}$ & $10^{3}$ & $10^{2}$ & - & 51 & & - & - & - & - & - & - & & $10^{1}$ & 0 & 0 & 54 & 108 & 216 \\
\hline \multirow[t]{6}{*}{ Ensaio3 } & $-/ \mathrm{O}_{3}$ & & $10^{3}$ & - & - & $10^{3}$ & - & & $10^{2}$ & $10^{2}$ & $10^{1}$ & 25 & 25 & 29 & & - & - & - & - & - & - \\
\hline & $\mathrm{O}_{3} / \mathrm{O}_{3}$ & & $10^{3}$ & $10^{3}$ & $10^{3}$ & - & 1 & & $10^{1}$ & $10^{1}$ & $10^{1}$ & 30 & 24 & 21 & & - & - & - & - & - & - \\
\hline & $-/ \mathrm{O}_{3}$ & & $10^{3}$ & - & - & $10^{3}$ & - & & $10^{2}$ & $10^{2}$ & $10^{2}$ & 31 & 31 & 31 & & - & - & - & - & - & - \\
\hline & $\mathrm{UV} / \mathrm{O}_{3}$ & & $10^{3}$ & $10^{3}$ & $10^{2}$ & - & 51 & & $10^{1}$ & $10^{1}$ & $10^{1}$ & 34 & 30 & 31 & & - & - & - & - & - & - \\
\hline & $-/ \mathrm{UV}$ & & $10^{3}$ & - & - & $10^{3}$ & - & & - & - & - & - & - & - & & $10^{2}$ & $10^{2}$ & $10^{2}$ & 66 & 108 & 216 \\
\hline & $\mathrm{O}_{3} / \mathrm{UV}$ & & $10^{3}$ & $10^{3}$ & $10^{2}$ & - & 1 & & - & - & - & - & - & - & & $10^{2}$ & $10^{1}$ & $10^{1}$ & 54 & 132 & 264 \\
\hline
\end{tabular}

$\mathrm{T}_{1}$ : Tempo de contato, $\mathrm{O}_{3}(\mathrm{~min}) . \mathrm{T}_{2}$ : Tempo de contato, UV (s). [a] Número de sobreviventes em ordem de grandeza (NMP/100mL). [b] O $3: \mathrm{mg} / \mathrm{L}$. [c] UV:mW.s/cm².

P1: Efluente bruto. P2: Efluente bruto após pré-desinfecção. P3: Efluente após pré-desinfecção seguido de tratamento biológico.

P4: Efluente bruto seguido de tratamento biológico. 
Tabela 8.15: Variação da população de coliformes totais (ensaios 1 e 3).

\begin{tabular}{|c|c|c|c|c|c|c|c|c|c|c|c|c|c|c|c|c|c|c|c|c|c|}
\hline & & \multirow[b]{3}{*}{ A: } & \multicolumn{5}{|c|}{ Etapa 1 - Pré-desinfecção } & \multirow[b]{3}{*}{$\mathrm{T}_{1}:$} & \multicolumn{13}{|c|}{ Etapa 2 - Desinfecção } \\
\hline & & & \multicolumn{4}{|c|}{ Sobreviventes ${ }^{a}$} & \multirow{2}{*}{$\begin{array}{c}\text { Dose }^{b c} \\
\text { P2 }\end{array}$} & & \multicolumn{3}{|c|}{ Sobreviventes ${ }^{a}$} & \multicolumn{3}{|c|}{$D o s e^{b}$} & \multirow[b]{2}{*}{$\mathrm{T}_{2}:$} & \multicolumn{3}{|c|}{ Sobreviventes ${ }^{a}$} & \multicolumn{3}{|c|}{$D o s e^{c}$} \\
\hline & & & $\mathrm{P} 1$ & $\mathrm{P} 2$ & $\mathrm{P} 3$ & $\mathrm{P} 4$ & & & 5 & 7 & 10 & 5 & 7 & 10 & & 30 & 60 & 120 & 30 & 60 & 120 \\
\hline \multirow[t]{8}{*}{ Ensaio1 } & $-/ \mathrm{O}_{3}$ & & $10^{6}$ & - & - & $10^{6}$ & - & & $10^{2}$ & $10^{2}$ & $10^{2}$ & 32 & 32 & 36 & & - & - & - & - & - & - \\
\hline & $\mathrm{O}_{3} / \mathrm{O}_{3}$ & & $10^{6}$ & $10^{6}$ & $10^{6}$ & - & 1 & & $10^{2}$ & $10^{2}$ & $10^{2}$ & 30 & 31 & 29 & & - & - & - & - & - & - \\
\hline & $-/ \mathrm{O}_{3}$ & & $10^{7}$ & - & - & $10^{6}$ & - & & $10^{4}$ & $10^{3}$ & $10^{3}$ & 28 & 28 & 28 & & - & - & - & - & - & - \\
\hline & $\mathrm{UV} / \mathrm{O}_{3}$ & & $10^{7}$ & $10^{6}$ & $10^{5}$ & - & 51 & & $10^{2}$ & $10^{3}$ & $10^{3}$ & 22 & 27 & 27 & & - & - & - & - & - & - \\
\hline & $-/ \mathrm{UV}$ & & $10^{6}$ & - & - & $10^{5}$ & - & & - & - & - & - & - & - & & $10^{4}$ & $10^{3}$ & $10^{3}$ & 66 & 138 & 288 \\
\hline & $\mathrm{O}_{3} / \mathrm{UV}$ & & $10^{6}$ & $10^{6}$ & $10^{5}$ & - & 1 & & - & - & - & - & - & - & & $10^{3}$ & $10^{3}$ & $10^{3}$ & 72 & 150 & 324 \\
\hline & $-/ \mathrm{UV}$ & & $10^{7}$ & - & - & $10^{7}$ & - & & - & - & - & - & - & - & & $10^{4}$ & $10^{4}$ & $10^{4}$ & 61 & 116 & 239 \\
\hline & $\mathrm{UV} / \mathrm{UV}$ & & $10^{7}$ & $10^{7}$ & $10^{6}$ & - & 51 & & - & - & - & - & - & - & & $10^{4}$ & $10^{3}$ & $10^{3}$ & 55 & 115 & 227 \\
\hline \multirow[t]{6}{*}{ Ensaio3 } & $-/ \mathrm{O}_{3}$ & & $10^{5}$ & - & - & $10^{5}$ & - & & $10^{2}$ & $10^{2}$ & $10^{3}$ & 25 & 25 & 29 & & - & - & - & - & - & - \\
\hline & $\mathrm{O}_{3} / \mathrm{O}_{3}$ & & $10^{5}$ & $10^{6}$ & $10^{5}$ & - & 1 & & $10^{2}$ & $10^{2}$ & $10^{2}$ & 30 & 24 & 21 & & - & - & - & - & - & - \\
\hline & $-/ \mathrm{O}_{3}$ & & $10^{6}$ & - & - & $10^{5}$ & - & & $10^{4}$ & $10^{3}$ & $10^{3}$ & 31 & 31 & 31 & & - & - & - & - & - & - \\
\hline & $\mathrm{UV} / \mathrm{O}_{3}$ & & $10^{6}$ & $10^{3}$ & $10^{5}$ & - & 51 & & $10^{2}$ & 0 & $10^{2}$ & 34 & 30 & 31 & & - & - & - & - & - & - \\
\hline & $-/ \mathrm{UV}$ & & $10^{6}$ & - & - & $10^{6}$ & - & & - & - & - & - & - & - & & $10^{3}$ & $10^{3}$ & $10^{3}$ & 66 & 108 & 216 \\
\hline & $\mathrm{O}_{3} / \mathrm{UV}$ & & $10^{6}$ & $10^{6}$ & $10^{5}$ & - & 1 & & - & - & - & - & - & - & & $10^{3}$ & $10^{2}$ & $10^{2}$ & 54 & 132 & 264 \\
\hline
\end{tabular}

$\mathrm{T}_{1}$ : Tempo de contato, $\mathrm{O}_{3}(\mathrm{~min}) . \mathrm{T}_{2}$ : Tempo de contato, UV (s). [a] Número de sobreviventes em ordem de grandeza (UFC/100mL). [b] O $3: \mathrm{mg} / \mathrm{L}$. [c] UV:mW.s/cm².

P1: Efluente bruto. P2: Efluente bruto após pré-desinfecção. P3: Efluente após pré-desinfecção seguido de tratamento biológico.

P4: Efluente bruto seguido de tratamento biológico. 


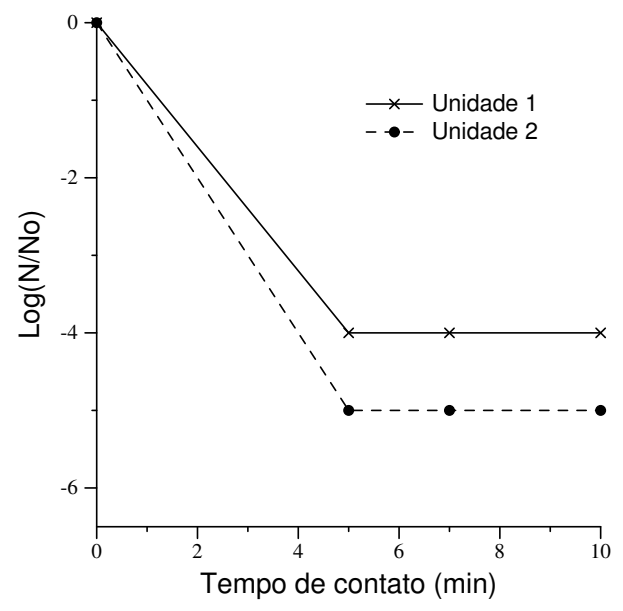

(a) $\mathrm{O}_{3} / \mathrm{O}_{3}$

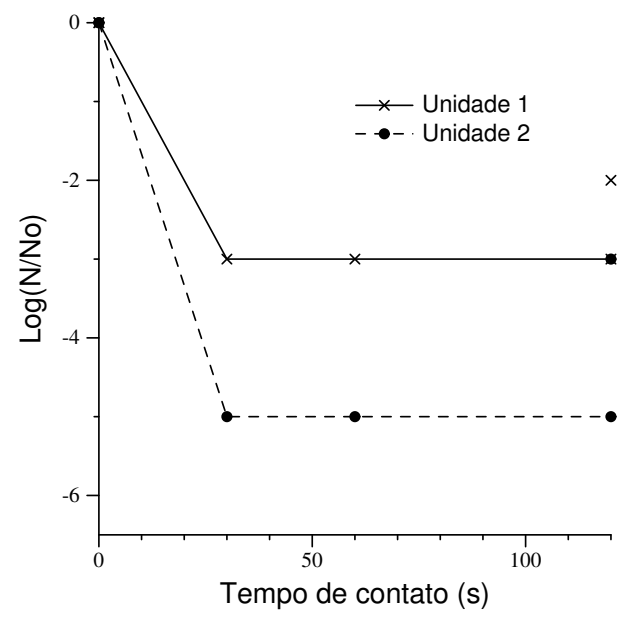

(c) $\mathrm{O}_{3} / \mathrm{UV}$

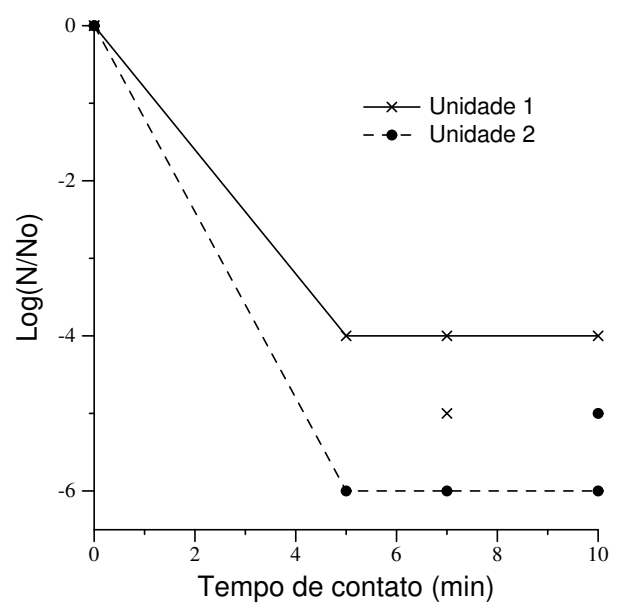

(b) $\mathrm{UV} / \mathrm{O}_{3}$

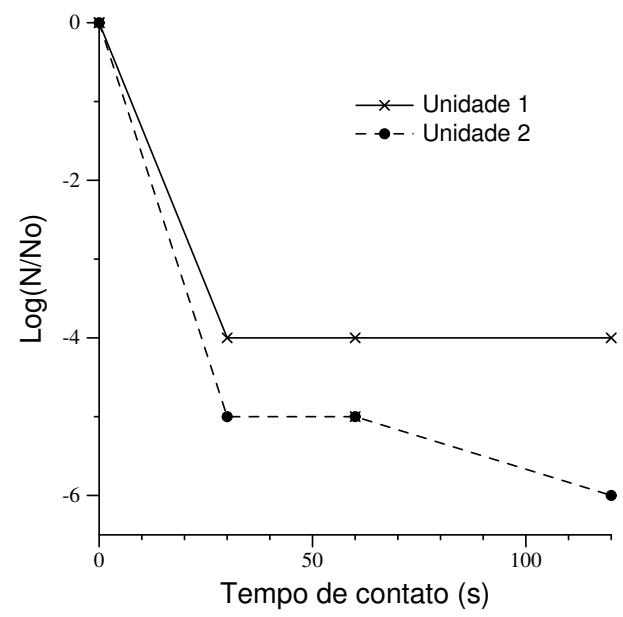

(d) $\mathrm{UV} / \mathrm{UV}$

Figura 8.7: Variação da população de E. coli na etapa 2 (ensaio 1).

Unidade 1: Método convencional. Unidade 2: Método alternativo. $\mathrm{O}_{3}: 5,7$ e 10 minutos. UV: 30, 60 e 120 segundos. 


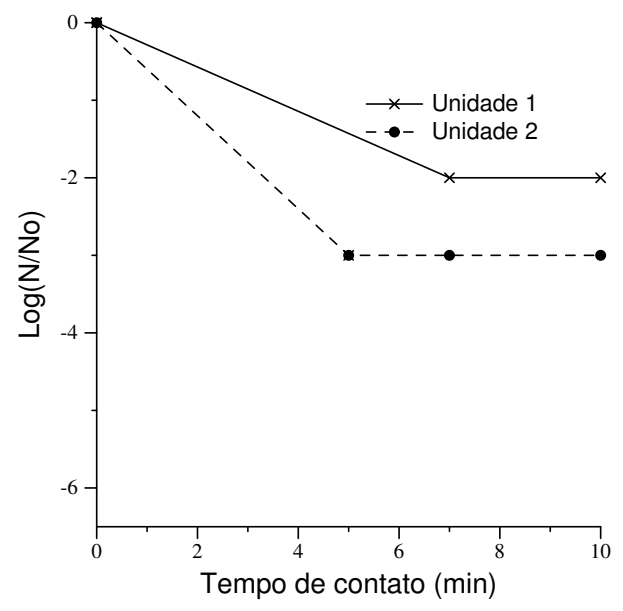

(a) $\mathrm{O}_{3} / \mathrm{O}_{3}$

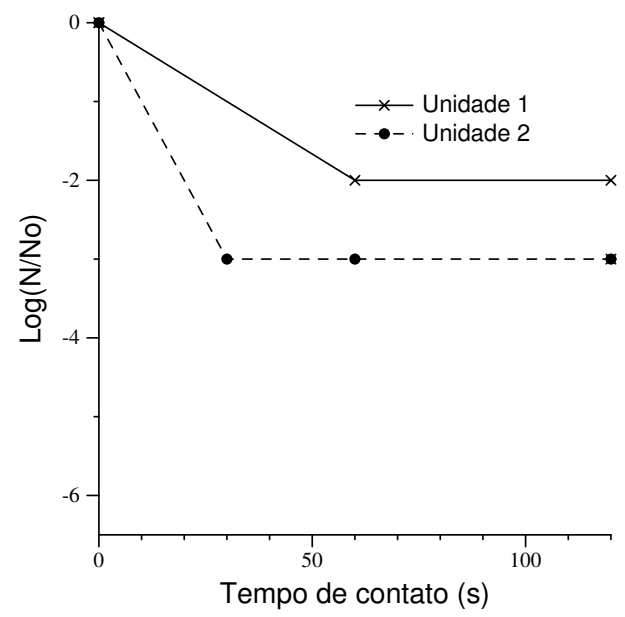

(c) $\mathrm{O}_{3} / \mathrm{UV}$

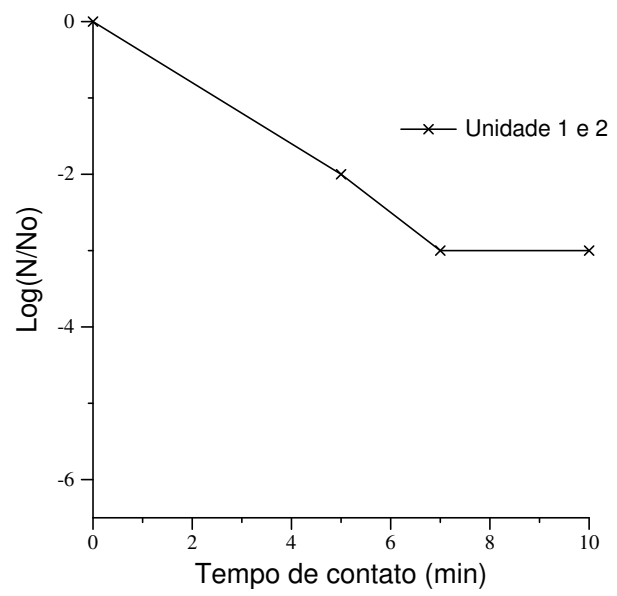

(b) $\mathrm{UV} / \mathrm{O}_{3}$

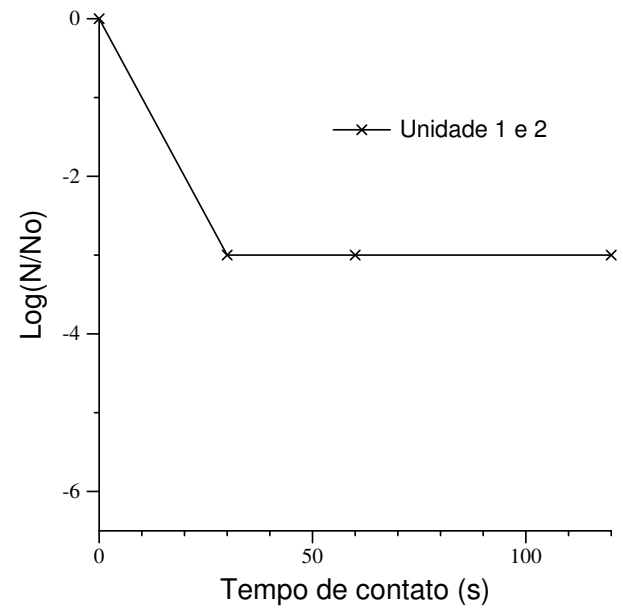

(d) $\mathrm{UV} / \mathrm{UV}$

Figura 8.8: Variação da população de colifagos na etapa 2 (ensaio 1).

Unidade 1: Método convencional. Unidade 2: Método alternativo.

$\mathrm{O}_{3}: 5,7$ e 10 minutos. UV: 30, 60 e 120 segundos. 


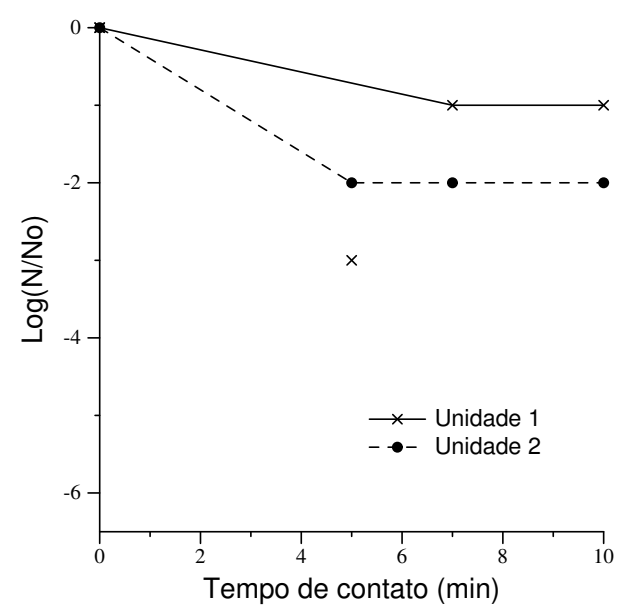

(a) $\mathrm{O}_{3} / \mathrm{O}_{3}$

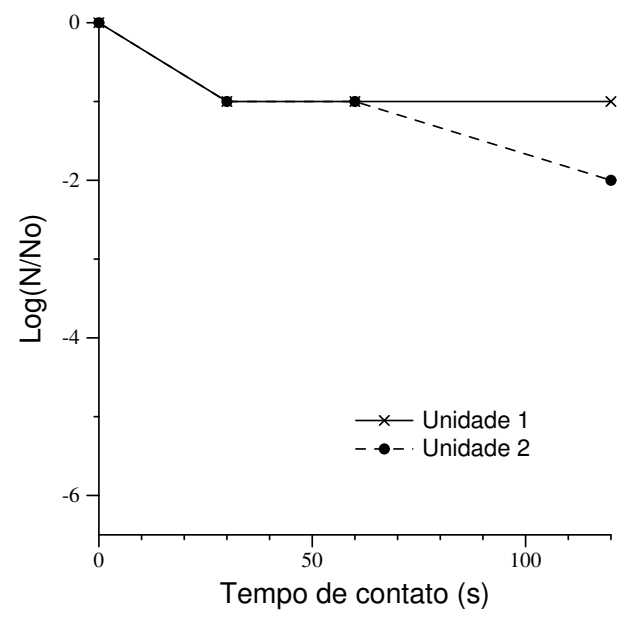

(c) $\mathrm{O}_{3} / \mathrm{UV}$

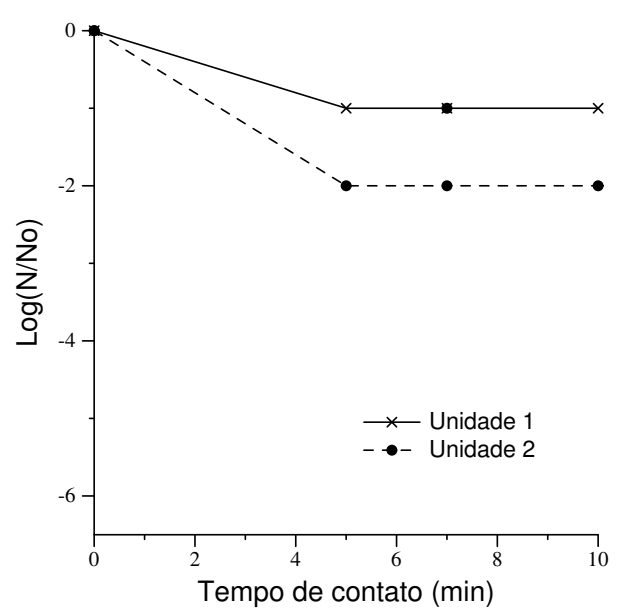

(b) $\mathrm{UV} / \mathrm{O}_{3}$

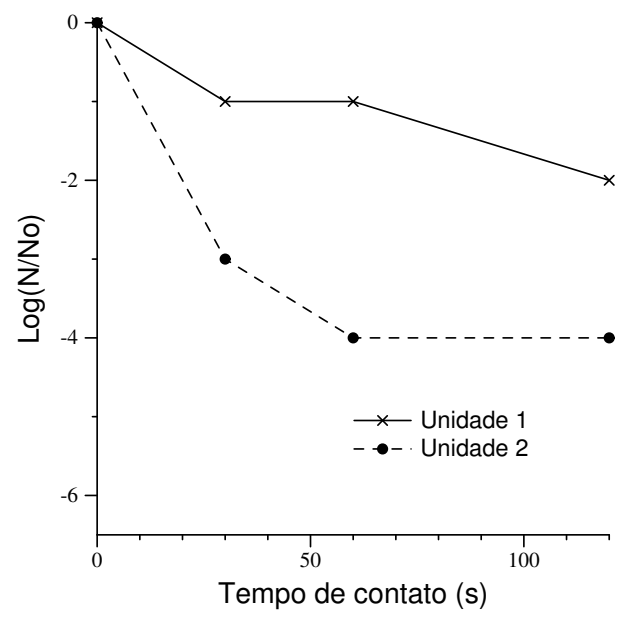

(d) $\mathrm{UV} / \mathrm{UV}$

Figura 8.9: Variação da população de $C$. perfringens na etapa 2 (ensaio 1).

Unidade 1: Método convencional. Unidade 2: Método alternativo.

$\mathrm{O}_{3}: 5,7$ e 10 minutos. UV: 30, 60 e 120 segundos. 


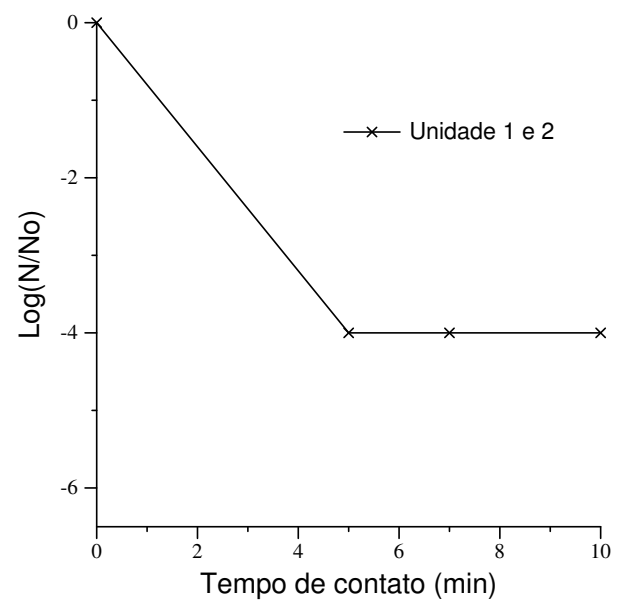

(a) $\mathrm{O}_{3} / \mathrm{O}_{3}$

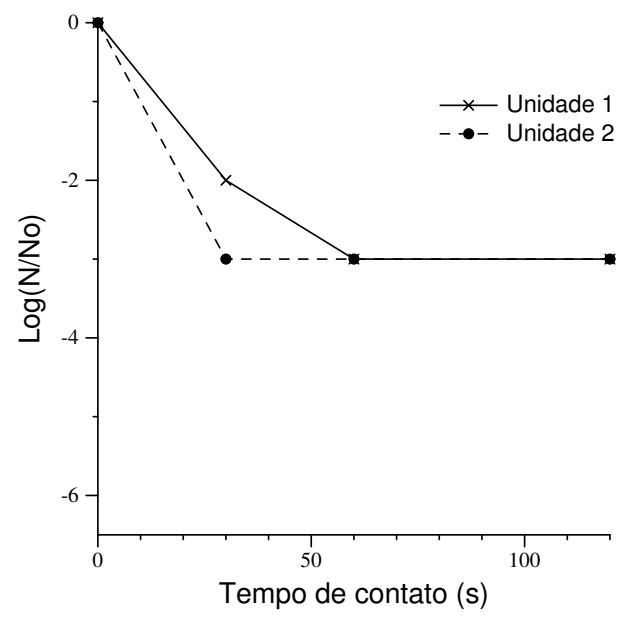

(c) $\mathrm{O}_{3} / \mathrm{UV}$

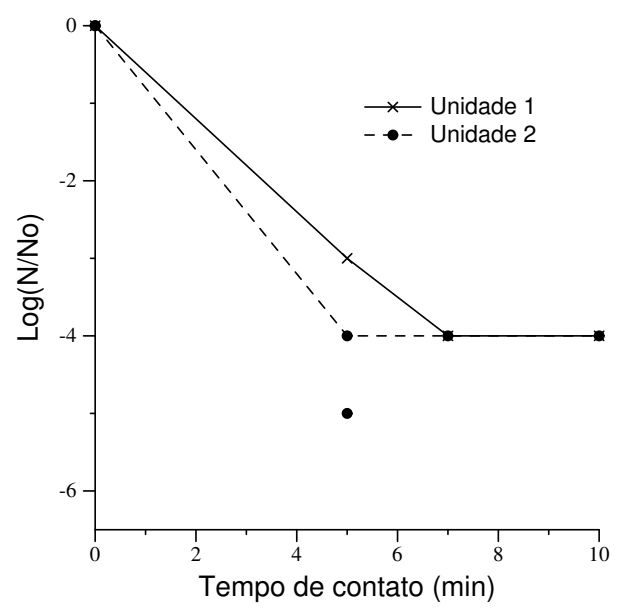

(b) $\mathrm{UV} / \mathrm{O}_{3}$

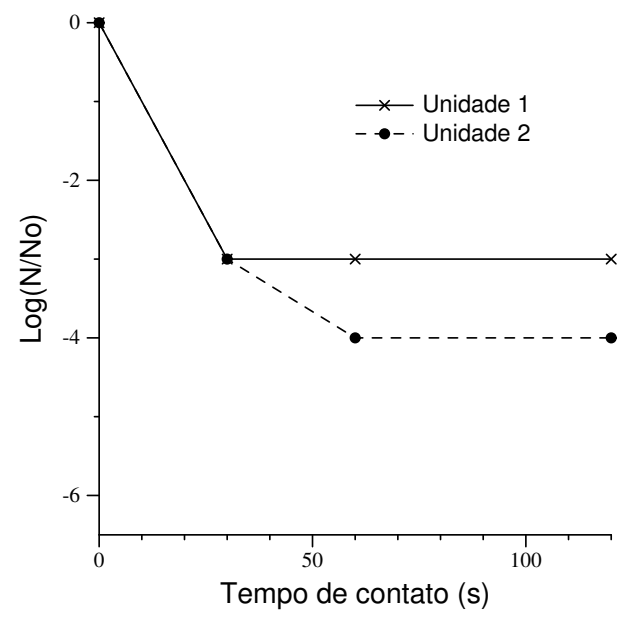

(d) $\mathrm{UV} / \mathrm{UV}$

Figura 8.10: Variação da população de coliformes totais na etapa 2 (ensaio 1).

Unidade 1: Método convencional. Unidade 2: Método alternativo.

$\mathrm{O}_{3}: 5,7$ e 10 minutos. UV: 30, 60 e 120 segundos. 


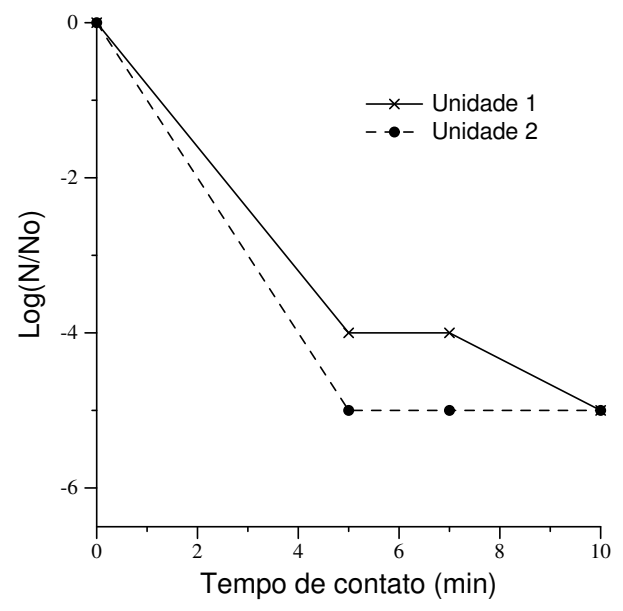

(a) $\mathrm{O}_{3} / \mathrm{O}_{3}$

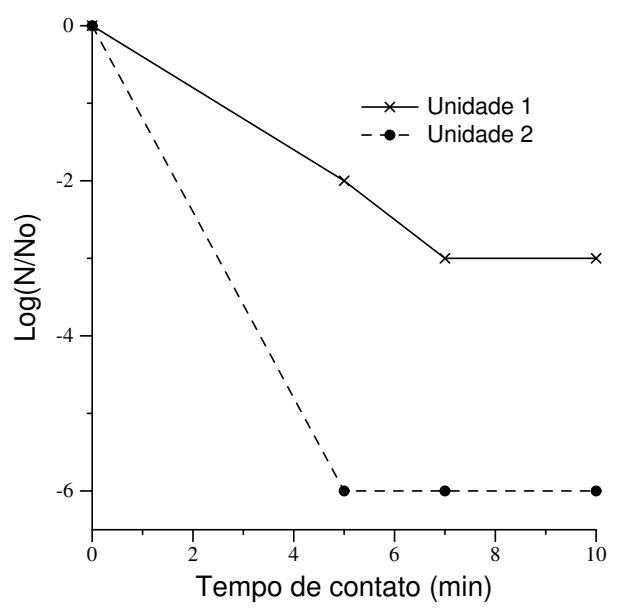

(b) $\mathrm{UV} / \mathrm{O}_{3}$

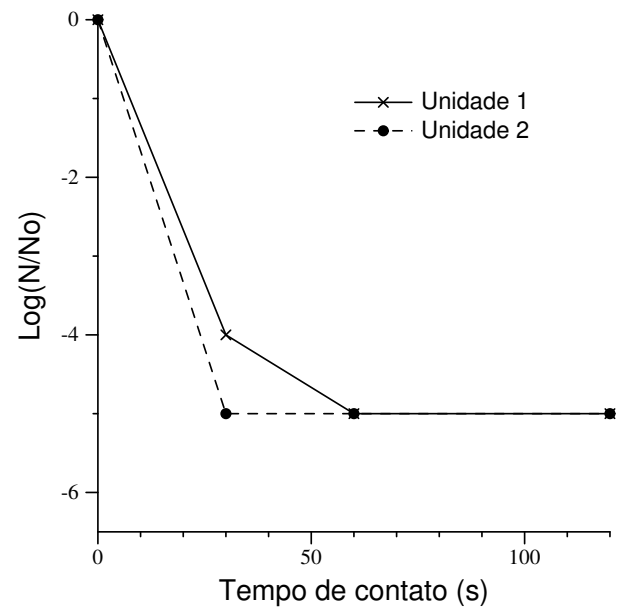

(c) $\mathrm{O}_{3} / \mathrm{UV}$

Figura 8.11: Variação da população de E. coli na etapa 2 (ensaio 3).

Unidade 1: Método convencional. Unidade 2: Método alternativo. $\mathrm{O}_{3}: 5,7$ e 10 minutos. UV: 30, 60 e 120 segundos. 


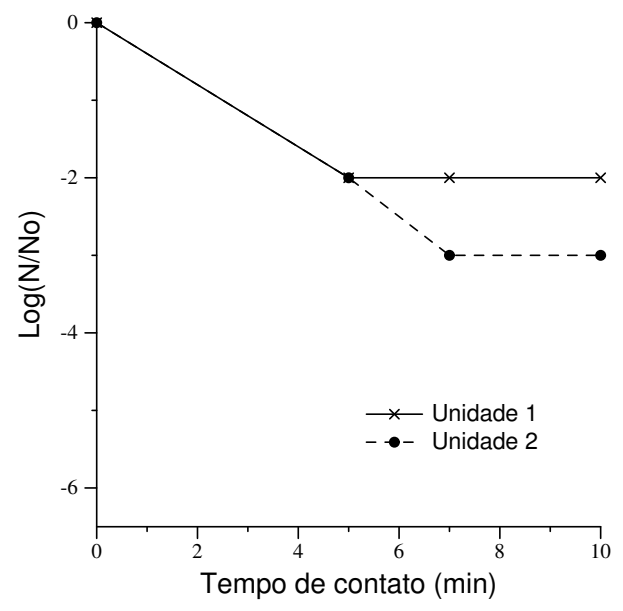

(a) $\mathrm{O}_{3} / \mathrm{O}_{3}$

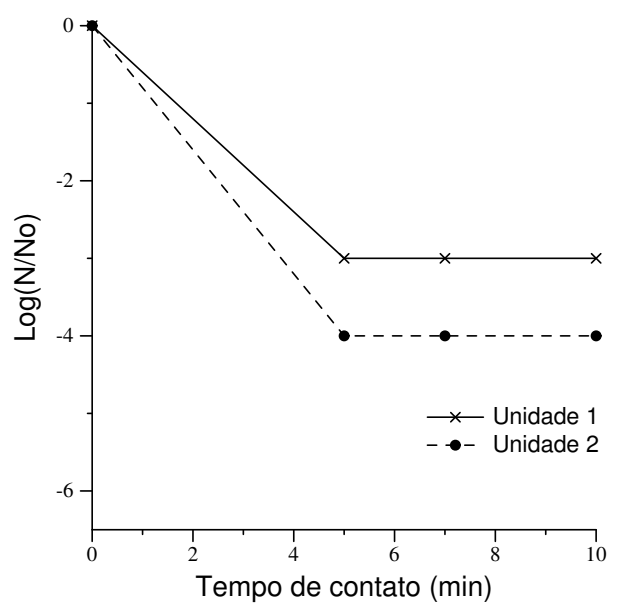

(b) $\mathrm{UV} / \mathrm{O}_{3}$

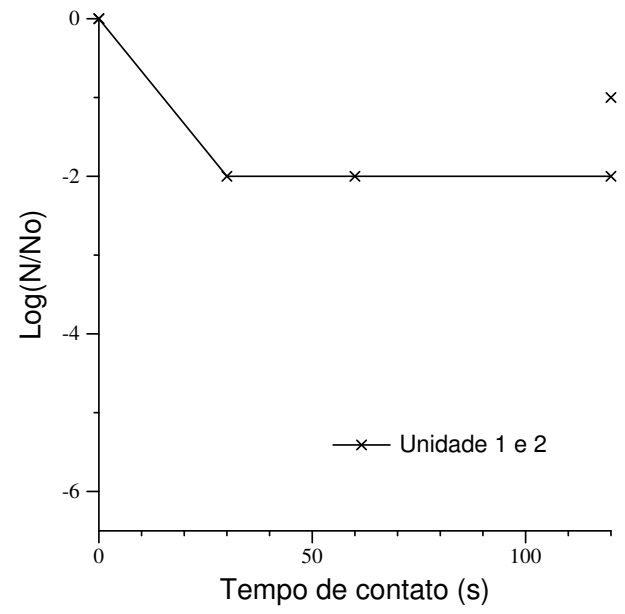

(c) $\mathrm{O}_{3} / \mathrm{UV}$

Figura 8.12: Variação da população de colifagos na etapa 2 (ensaio 3).

Unidade 1: Método convencional. Unidade 2: Método alternativo. $\mathrm{O}_{3}: 5,7$ e 10 minutos. UV: 30, 60 e 120 segundos. 


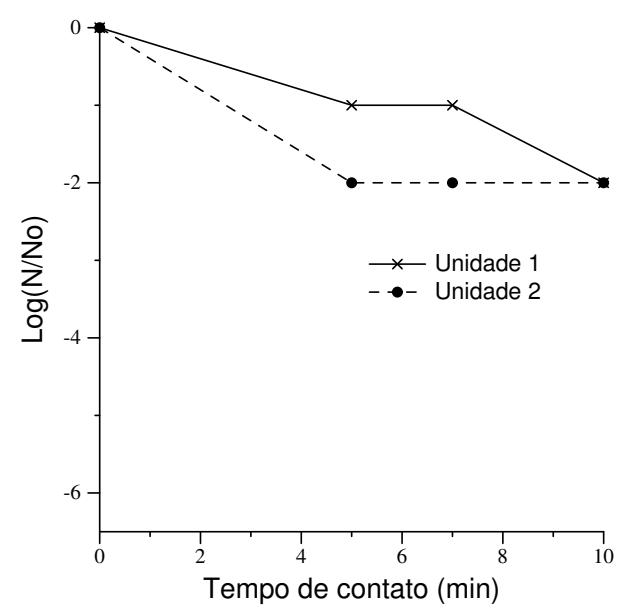

(a) $\mathrm{O}_{3} / \mathrm{O}_{3}$

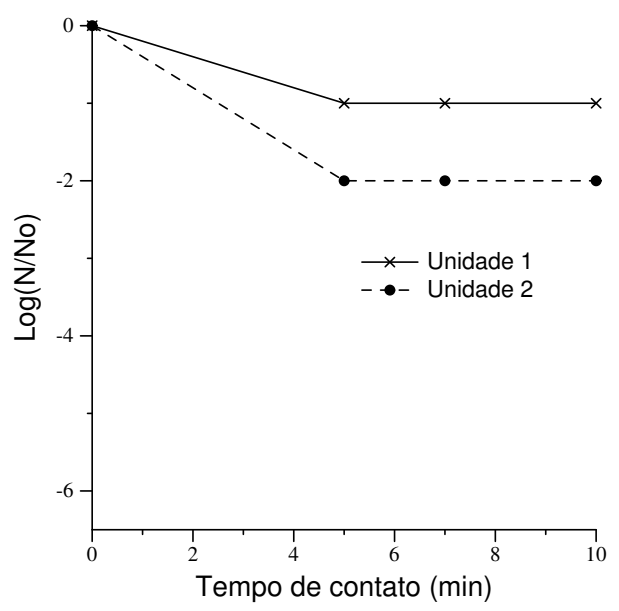

(b) $\mathrm{UV} / \mathrm{O}_{3}$

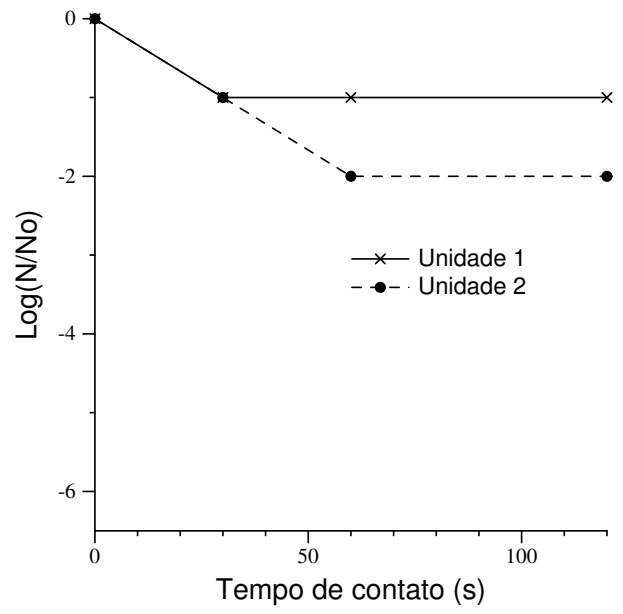

(c) $\mathrm{O}_{3} / \mathrm{UV}$

Figura 8.13: Variação da população de C. perfringens na etapa 2 (ensaio 3). Unidade 1: Método convencional. Unidade 2: Método alternativo. $\mathrm{O}_{3}: 5,7$ e 10 minutos. UV: 30, 60 e 120 segundos. 


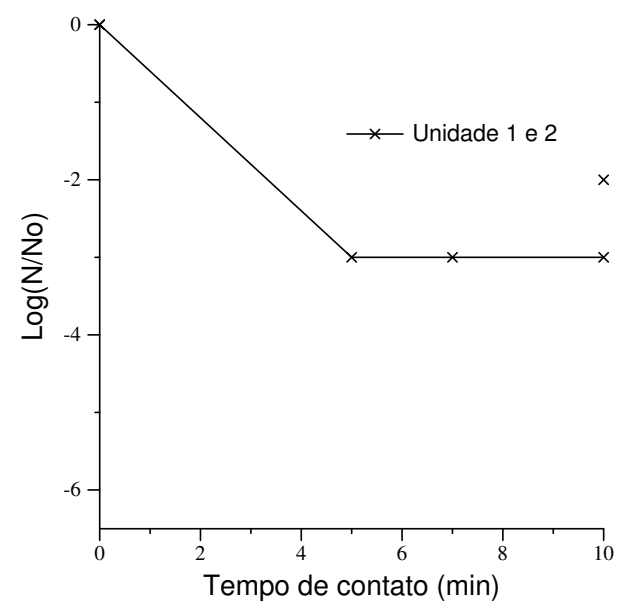

(a) $\mathrm{O}_{3} / \mathrm{O}_{3}$

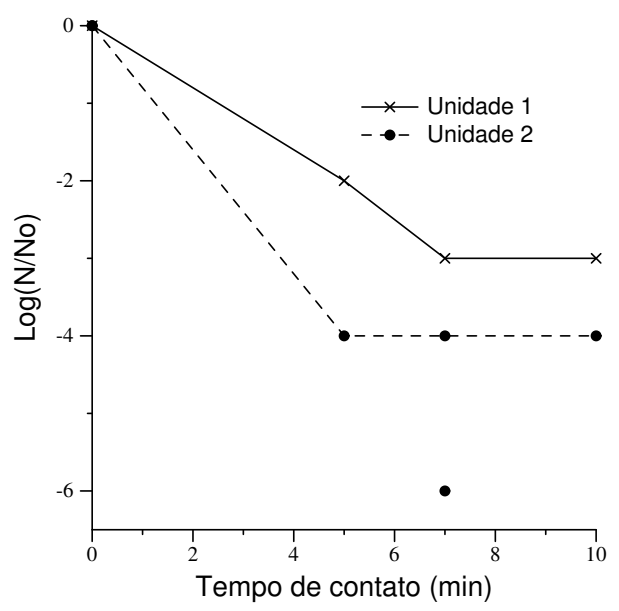

(b) $\mathrm{UV} / \mathrm{O}_{3}$

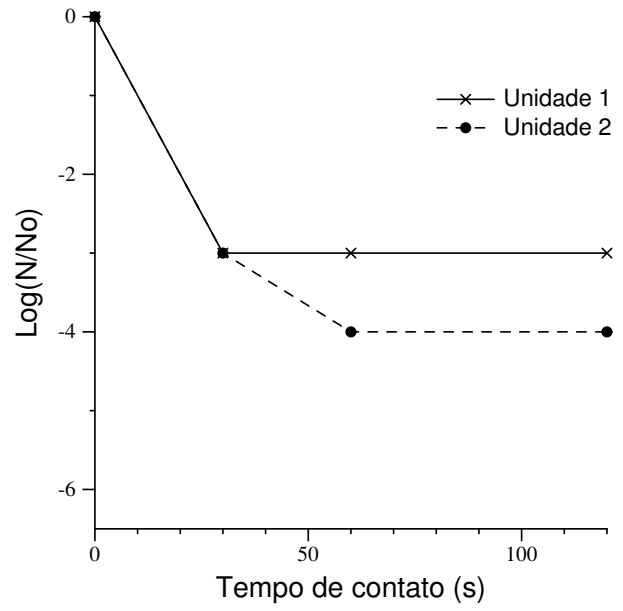

(c) $\mathrm{O}_{3} / \mathrm{UV}$

Figura 8.14: Variação da população de coliformes totais na etapa 2 (ensaio 3).

Unidade 1: Método convencional. Unidade 2: Método alternativo. $\mathrm{O}_{3}: 5,7$ e 10 minutos. UV: 30, 60 e 120 segundos. 
Tabela 8.16: Eficiência de inativação de Escherichia coli (ensaios 1 e 3).

\begin{tabular}{|c|c|c|c|c|c|c|c|c|c|c|c|c|c|c|c|c|c|}
\hline \multicolumn{9}{|c|}{ Eficiência (\%) - Unidade 1} & \multicolumn{9}{|c|}{ Eficiência (\%) - Unidade 2 } \\
\hline $\mathrm{P} 4$ & $\mathrm{~T}_{1}$ & 5 & 7 & 10 & $\mathrm{~T}_{2}$ & 30 & 60 & 120 & P3 & $\mathrm{T}_{1}$ & 5 & 7 & 10 & $\mathrm{~T}_{2}$ : & 30 & 60 & 120 \\
\hline
\end{tabular}

\begin{tabular}{|c|c|c|c|c|c|c|c|c|c|c|c|c|c|c|c|}
\hline Ensaio 1 & & & & & & & & & & & & & & & \\
\hline & $\mathrm{O}_{3} / \mathrm{O}_{3}$ & 90,0 & 99,999 & 99,99 & 99,99 & - & - & - & 90,0 & 100,0 & 100,0 & 100,0 & - & - & - \\
\hline & $\mathrm{UV} / \mathrm{O}_{3}$ & 90,0 & 99,99 & 99,999 & 99,99 & - & - & - & 99,0 & 100,0 & 100,0 & 99,999 & - & - & - \\
\hline & $\mathrm{O}_{3} / \mathrm{UV}$ & 0 & - & - & - & 99,9 & 99,9 & 99,0 & 0 & - & - & - & 100,0 & 100,0 & 99,9 \\
\hline & UV/UV & 90,0 & - & - & - & 99,99 & 99,999 & 99,99 & 99,0 & - & - & - & 99,999 & 99,999 & 100,0 \\
\hline \multicolumn{16}{|l|}{ Ensaio 3} \\
\hline & $\mathrm{O}_{3} / \mathrm{O}_{3}$ & 90,0 & 99,99 & 99,99 & 100,0 & - & - & - & 90,0 & 100,0 & 99,999 & 100,0 & - & - & - \\
\hline & $\mathrm{UV} / \mathrm{O}_{3}$ & 90,0 & 99,0 & 99,9 & 99,9 & - & - & - & 99,0 & 99,9999 & 100,0 & 99,9999 & - & - & - \\
\hline & $\mathrm{O}_{3} / \mathrm{UV}$ & 0 & - & - & - & 99,99 & 100,0 & 100,0 & 0 & - & - & - & 100,0 & 100,0 & 100,0 \\
\hline
\end{tabular}

$\mathrm{T}_{1}$ : Tempo de contato, $\mathrm{O}_{3}(\mathrm{~min}) . \mathrm{T}_{2}$ : Tempo de contato, UV (s). Unidade 1: Método convencional. Unidade 2: Método alternativo.

P3: Efluente após pré-desinfecção seguido de tratamento biológico. P4: Efluente bruto seguido de tratamento biológico. Ensaio 3 UV/UV não foi realizado. 
Tabela 8.17: Eficiência de inativação de colifagos (ensaios 1 e 3).

\begin{tabular}{|c|c|c|c|c|c|c|c|c|c|c|c|c|c|c|c|c|c|}
\hline \multicolumn{9}{|c|}{ Eficiência (\%) - Unidade 1} & \multicolumn{9}{|c|}{ Eficiência (\%) - Unidade 2} \\
\hline $\mathrm{P} 4$ & $\mathrm{~T}_{1}:$ & 5 & 7 & 10 & $\mathrm{~T}_{2}:$ & 30 & 60 & 120 & P3 & $\mathrm{T}_{1}:$ & 5 & 7 & 10 & $\mathrm{~T}_{2}:$ & 30 & 60 & 120 \\
\hline
\end{tabular}

\begin{tabular}{|c|c|c|c|c|c|c|c|c|c|c|c|c|c|c|c|}
\hline \multicolumn{16}{|l|}{ Ensaio 1} \\
\hline & $\mathrm{O}_{3} / \mathrm{O}_{3}$ & 0 & 100 & 99,0 & 99,0 & - & - & - & 90,0 & 100,0 & 99,9 & 100,0 & - & - & - \\
\hline & $\mathrm{UV} / \mathrm{O}_{3}$ & 0 & 99,0 & 100,0 & 100,0 & - & - & - & 90,0 & 99,0 & 100,0 & 100,0 & - & - & - \\
\hline & $\mathrm{O}_{3} / \mathrm{UV}$ & 0 & - & - & - & 100,0 & 100,0 & 99,0 & 99,9 & - & - & - & 100,0 & 100,0 & 100,0 \\
\hline & UV/UV & 0 & - & - & - & 100,0 & 100,0 & 100,0 & 90,0 & - & - & - & 100,0 & 100,0 & 100,0 \\
\hline \multicolumn{16}{|l|}{ Ensaio 3} \\
\hline & $\mathrm{O}_{3} / \mathrm{O}_{3}$ & 0 & 99,0 & 99,0 & 99,0 & - & - & - & 90,0 & 99,0 & 100,0 & 100,0 & - & - & - \\
\hline & $\mathrm{UV} / \mathrm{O}_{3}$ & 0 & 99,99 & 99,99 & 99,99 & - & - & - & 99,99 & 100,0 & 100,0 & 100,0 & - & - & - \\
\hline & $\mathrm{O}_{3} / \mathrm{UV}$ & 0 & - & - & - & 100,0 & 100,0 & 90,0 & 0 & - & - & - & 100,0 & 100,0 & 100,0 \\
\hline
\end{tabular}

$\mathrm{T}_{1}$ : Tempo de contato, $\mathrm{O}_{3}(\mathrm{~min}) . \mathrm{T}_{2}$ : Tempo de contato, UV (s). Unidade 1: Método convencional. Unidade 2: Método alternativo.

P3: Efluente após pré-desinfecção seguido de tratamento biológico. P4: Efluente bruto seguido de tratamento biológico. Ensaio 3 UV/UV não foi realizado. 
Tabela 8.18: Eficiência de inativação de Clostridium perfringens (ensaios 1 e 3).

\begin{tabular}{|c|c|c|c|c|c|c|c|c|c|c|c|c|c|c|c|c|c|c|c|c|}
\hline & & \multicolumn{9}{|c|}{ Eficiência (\%) - Unidade 1} & & \multicolumn{9}{|c|}{ Eficiência (\%) - Unidade 2} \\
\hline & & $\mathrm{P} 4$ & $\mathrm{~T}_{1}:$ & 5 & 7 & 10 & $\mathrm{~T}_{2}$ & 30 & 60 & 120 & & P3 & $\mathrm{T}_{1}:$ & 5 & 7 & 10 & $\mathrm{~T}_{2}$ & 30 & 60 & 120 \\
\hline \multicolumn{21}{|l|}{ Ensaio 1} \\
\hline & $\mathrm{O}_{3} / \mathrm{O}_{3}$ & 0 & & 99,9 & 90,0 & 90,0 & & - & - & - & & 90,0 & & 99,0 & 99,0 & 99,0 & & - & - & - \\
\hline & $\mathrm{UV} / \mathrm{O}_{3}$ & 0 & & 90,0 & 90,0 & 90,0 & & - & - & - & & 90,0 & & 99,0 & 90,0 & 99,0 & & - & - & - \\
\hline & $\mathrm{O}_{3} / \mathrm{UV}$ & 0 & & - & - & - & & 90,0 & 90,0 & 90,0 & & 0 & & - & - & - & & 90,0 & 90,0 & 100,0 \\
\hline & $\mathrm{UV} / \mathrm{UV}$ & 0 & & - & - & - & & 87,27 & 84,54 & 99,09 & & 99,09 & & - & - & - & & 80,00 & 100 & 100 \\
\hline \multicolumn{21}{|l|}{ Ensaio 3} \\
\hline & $\mathrm{O}_{3} / \mathrm{O}_{3}$ & 0 & & 90,0 & 90,0 & 99,0 & & - & - & - & & 0 & & 99,0 & 99,0 & 99,0 & & - & - & - \\
\hline & $\mathrm{UV} / \mathrm{O}_{3}$ & 0 & & 90,0 & 90,0 & 90,0 & & - & - & - & & 90 & & 99,0 & 99,0 & 99,0 & & - & - & - \\
\hline & $\mathrm{O}_{3} / \mathrm{UV}$ & 0 & & - & - & - & & 90,0 & 90,0 & 90,0 & 99,0 & & - & - & - & & 90,0 & & 90,0 & 99,0 \\
\hline
\end{tabular}

$\mathrm{T}_{1}$ : Tempo de contato, $\mathrm{O}_{3}(\mathrm{~min}) . \mathrm{T}_{2}$ : Tempo de contato, UV (s). Unidade 1: Método convencional. Unidade 2: Método alternativo.

P3: Efluente após pré-desinfecção seguido de tratamento biológico. P4: Efluente bruto seguido de tratamento biológico. Ensaio 3 UV/UV não foi realizado. 
Tabela 8.19: Eficiência de inativação de coliformes totais (ensaios 1 e 3).

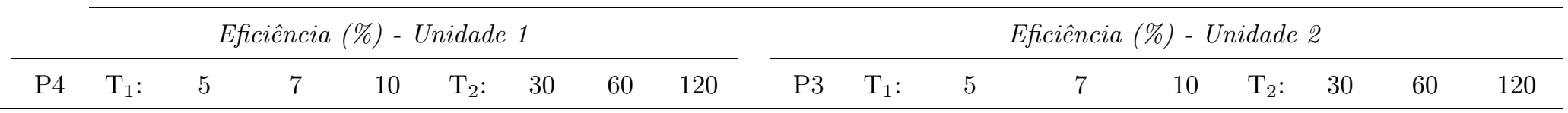

\begin{tabular}{|c|c|c|c|c|c|c|c|c|c|c|c|c|c|c|c|}
\hline Ensaio 1 & & & & & & & & & & & & & & & \\
\hline & $\mathrm{O}_{3} / \mathrm{O}_{3}$ & 0 & 99,99 & 99,99 & 99,99 & - & - & - & 0 & 99,99 & 99,99 & 99,99 & - & - & - \\
\hline & $\mathrm{UV} / \mathrm{O}_{3}$ & 90,0 & 99,9 & 99,99 & 99,99 & - & - & - & 99,0 & 99,999 & 99,99 & 99,99 & - & - & - \\
\hline & $\mathrm{O}_{3} / \mathrm{UV}$ & 90,0 & - & - & - & 99,0 & 99,9 & 99,9 & 90,0 & - & - & - & 99,9 & 99,9 & 99,9 \\
\hline & $\mathrm{UV} / \mathrm{UV}$ & & - & - & - & & & & & - & - & - & & & \\
\hline \multicolumn{16}{|l|}{ Ensaio 3} \\
\hline & $\mathrm{O}_{3} / \mathrm{O}_{3}$ & 0 & 99,9 & 99,9 & 99,0 & - & - & - & 0 & 99,9 & 99,99 & 99,99 & - & - & - \\
\hline & $\mathrm{UV} / \mathrm{O}_{3}$ & 90,0 & 99,0 & 99,9 & 99,9 & - & - & - & 90,0 & 99,99 & 99,9999 & 99,99 & - & - & - \\
\hline & $\mathrm{O}_{3} / \mathrm{UV}$ & 0 & - & - & - & 99,9 & 99,9 & 99,9 & 90,0 & - & - & - & 99,9 & 99,99 & 99,99 \\
\hline
\end{tabular}

$\mathrm{T}_{1}$ : Tempo de contato, $\mathrm{O}_{3}(\mathrm{~min}) . \mathrm{T}_{2}$ : Tempo de contato, UV (s). Unidade 1: Método convencional. Unidade 2: Método alternativo.

P3: Efluente após pré-desinfecção seguido de tratamento biológico. P4: Efluente bruto seguido de tratamento biológico. Ensaio 3 UV/UV não foi realizado. 


\section{Referências Bibliográficas}

ALMEIDA et al. (2004) Almeida, E., Assalin, M. R., Rosa, M. A., e Durán, N. Tratamento de esgoto por oxidação com ozônio. Química Nova, vol.27(no.5), 2004 .

ANDREADAKIS et al. (1999) Andreadakis, A., Mamais, D., Christoulas, D., e Kabylafka, S. Ultraviolet disinfection of secondary and tertiary effluent in the mediterranean region. Water Science Technology, 40(4-5):253-260, 1999.

APHA (1995) APHA. Standard Methods for the Examination of Water and Wastewater. American Public Health Association, American Water Works Association, Water Environment Federation, New York, 1995. 19.ed.

AWWA (1991) AWWA. Ozone in water treatment. American Water Works Association, Michigan, 1991.

BILOTTA (2000) Bilotta, P. Estudo comparativo da ação do ozônio e radiação UV na desinfecção de esgoto sanitário. Dissertação de Mestrado, Escola de Engenharia de São Carlos, Departamento de Hidráulica e Saneamento, 2000.

BITTON (1994) Bitton, G. Wastewater Microbiology. John Wiley \& Sons, New York, 1994.

BLUME \& NEIS (2004) Blume, T. e Neis, U. Improved wastewater disinfection by ultrasonic pre-treatment. Ultrasonics sonochemistry, 11:333-336, 2004.

BRAUN et al. (1986) Braun, A. M., Murette, M. T., e Oliveros, E. Radiométrie et actinométrie. Presses Polytechniques Romandes, 1986. p.542.

CHIANG et al. (1999) Chiang, P. C., Ko, Y. W., Liang, C. H., e Chang, E. E. Modeling an ozone bubble column for predicting its disinfection efficiency and control of DBP formation. Chemosphere, 39(1):55-70, 1999. 
CHIN \& BERUBE (2005) Chin, A. e Berube, P. R. Removal of disinfection byproduct precursors with ozone-UV advanced oxidation process. Water research, 39:2136-2144, 2005.

COLETTI (2003) Coletti, F. Inativação de microrganismos indicadores presentes em efluentes secundários de esgoto sanitário com radiação ultravioleta. Tese de Doutoramento, Escola de Engenharia de São Carlos, Universidade de São Paulo, 2003.

DANIEL (1989) Daniel, L. A. Desinfecção de efluentes de esgotos sanitários prédecantados empregando radiação ultravioleta. Tese de Mestrado, Departamento de Hidráulica e Saneamento, Escola de Engenharia de São Carlos, Universidade de São Paulo, 1989.

DANIEL (1993) Daniel, L. A. Desinfecção de esgotos com radiação ultravioleta: fotorreativação e obtenção de parâmetros cinéticos. Tese de Doutoramento, Departamento de Hidráulica e Saneamento, Escola de Engenharia de São Carlos, Universidade de São Paulo, 1993.

DRIEDGER et al. (2000) Driedger, A. M., Rennecker, J. L., e Marinas, J. B. Sequencial inativation of Cryptosporidium parvum oocytos with ozone and free chlorine. Water research, 34(14):3591-3597, 2000.

EPA (1999) EPA. Alternative Disinfectants and Oxidants Guidance Manual. Environmental Protection Agency, 1999.

EVANS (1972) Evans, F. L. Ozone in Water and Wastewater Treatment. Ann Arbor Science, Michigan, 1972.

FAIR et al. (1971) Fair, G. M., Geyer, J. C., e Okun, D. A. Purificación de Aguas y Tratamiento y Remoción de Aguas Residuales, volume 2. Editorial LimusaWiley S.A., México, 1971.

GADOTTI (2003) Gadotti, R. Pós-tratamento de efluente de reator anaeróbio compartimentado por oxidação com ozônio precedendo biofiltro aerado submerso. Tese de Doutoramento, Escola de Engenharia de São Carlos, Universidade de São Paulo, 2003.

GLAZE (1987) Glaze, W. H. Drinking-water treatment with ozone. Environment 
Science Technology, 21(3):224-229, 1987.

HARRIS (1995) Harris, D. C. Quantitative chemical analysis. W.H.Freeman and Company, New York, 1995. 4.ed.

HARRIS et al. (1987) Harris, G. D., Adams, V. D., Moore, W. M., e Sorensen, D. L. Potassium ferrioxalate as chemical actinometer in ultraviolet reactors. Journal of the Environmental Engineering Division - American Society of Civil Engineers, 113(3):612-625, 1987.

HARRIS et al. (1987b) Harris, G. D., Adams, V. D., Sorensen, D. L., e Curtis, M. S. Ultraviolet inactivation of selected bacteria and viruses with photoreactivation of bacteria. Water Research, 21(6):687-692, 1987.

HATCHARD \& PARKER (1956) Hatchard, C. G. e Parker, C. A. A new sensitive chemical actinometer. II - Potassium ferrioxalate as a standard chemical actinometer. In Royal Society of London, Serie A, 1956. p.518-536.

HO et al. (1998) Ho, C. H., Pitt, P., Mamais, D., Chiu, C., e D., J. Evaluation of UV disinfection systems for large-scale secondary effluent. Water Environmental Research, 70(6):1142-1150, 1998.

JANEX et al. (1998) Janex, M. L., Savoye, P., Do-Quang, Z., Blatchely, E., e Laîné, J. M. Impact of water quality and reactor hydrodynamics on wastewater disinfection by UV: Use of CFD modeling for performance optimization. Water Science Technology, 38(6):71-78, 1998.

JOHNSON (1975) Johnson, J. D. Disinfection of Water and Wastewater Using Ozone. Ann Arbor Science, Michigan, 1975.

KOIVUNEN \& HEINONEN-TANSKI (2005) Koivunen, J. e Heinonen-Tanski, H. Inativation of enteric microorganisms with chemical disinfectants, UV irradiation and combined chemical/UV treatment. Water research, 39:1519-1526, 2005 .

KOLLER (1958) Koller, L. R. Ultraviolet Radiation. John Wiley \& Sons, London, 1958. p.220.

LOGE et al. (1996) Loge, F. J., Emerick, R. W., Heath, M., Jacangelo, J., Tchobanoglous, G., e Darby, J. L. Ultraviolet disinfection of secondary wastewater 
effluents: prediction of performance and design. Water Environmental Research, 68(5):900-915, 1996.

MAUSTELLER (1989) Mausteller, J. W. Ozone. MSA Research Corporation, 1989.

MILTNER et al. (1992) Miltner, R. J., Shukairy, H. M., e Summers, R. S. Disinfection by-product formation and control by ozonation e biotreatment. American Water Works Association, 1992. p.53-55.

OLIVER \& COSGROVE (1975) Oliver, B. G. e Cosgrove, E. G. The disinfection of sewage treatment plant effluents using ultraviolet light. Canadian Journal of Chemical Engineering, 53(4):170-174, 1975.

PELCZAR et al. (1980) Pelczar, M., Reid, R., e Chan, E. C. S. Microbiologia. McGraw-Hill, São Paulo, 1980.

PHILLIPS (1983) Phillips, R. Sources and Applications of Ultraviolet Radiation. Academic Press, New York, 1983.

SKOOG et al. (1994) Skoog, D. A., West, D. M., e Holler, F. J. Analytical chemistry. Saunders College Pub., 1994. 6.ed.

SOTELO et al. (1989) Sotelo, J. L., Beltrán, F. J., Benitez, F., e Beltrán-Heredia, J. Henry's law constant for the ozone-water system. Water Research, 23(10):1239-1245, 1989.

STAEHELIN \& HOIGNÉ (1985) Staehelin, J. e Hoigné, J. Decomposition of ozone in water in the presence of organics solutes acting as promoters and inhibitors of radical chain reactions. Environment Science Technology, 19(12):12061213, 1985.

STANLEY \& JOHNSON (1991) Stanley, J. e Johnson, J. D. Analysis of ozone in aqueous solution, 1991.

WEF (1996) WEF. Wastewater Disinfection - Manual of Pratice. Water Environment Federation, USA, 1996. 